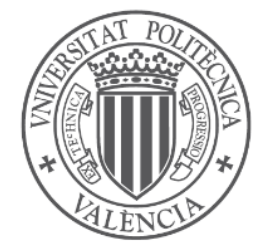

Universitat Politècnica de València

Departamento de Ingeniería Hidráulica y Medio Ambiente Programa de Doctorado de Ingeniería del Agua y Medioambiental

\title{
Exploring the possibilities of parsimonious nitrogen modelling in different ecosystems
}

\author{
AUTHOR \\ Cristina Puertes Castellano \\ SUPERVISORS \\ DR. FÉLIX FRANCÉS GARCÍA \\ DR. ANTONIO Lidón CEREZUELA \\ DRa. InMACULAdA BaUtista CARRASCosa
}

VALENCIA, JANUARY 2020 

A mis abuelos,

Marcial y Presenta 



\section{Agradecimientos}

Esta tesis doctoral no habría sido posible sin la financiación proporcionada por el Ministerio de Ciencia e Innovación a través del proyecto TETISMED (CGL2014-58127-C3-3-R) y la Unión Europea a través del proyecto LIFE17 CCA/ES/000063 RESILIENTFORESTS.

Me gustaría expresar mi más sincero agradecimiento:

- A mis directores de tesis, el Dr. Félix Francés, el Dr. Antonio Lidón y la Dra. Inmaculada Bautista por el tiempo y esfuerzo dedicado, por transmitirme sus conocimientos, por ayudarme a crecer como persona e investigadora y, sobre todo, por todos los ánimos. En especial al Dr. Félix Francés, por brindarme la oportunidad de realizar este trabajo.

- Al grupo Re-Forest por su colaboración, principalmente a la Dra. María González-Sanchis y al Dr. Antonio D. del Campo.

- A Faustino Martínez de CARM por darnos la oportunidad de trabajar en el caso real del Mar Menor. Sin él, esta tesis habría sido muy diferente.

- A todos mis compañeros del GIMHA a lo largo de estos años, por su predisposición para ayudar, el apoyo y los momentos compartidos. Especialmente a Vicente Escamilla, la Dra. Guiomar Ruiz-Pérez, el Dr. Mario Hernández, Shantosa Yudha, Carlos Echeverría, el Dr. Jonathan Romero, Carles Beneyto y Raquel Martínez, a los cuales puedo llamar amigos y a la Dra. Alicia García-Arias por creer que podía hacer cualquier cosa y animarme a ello.

- A Sofía Prats, por apoyarme y animarme en cada carrera y paseo.

- A mi familia, a todos y cada uno de ellos, pero en especial a mis padres por haberme dado lo más valioso que tengo, una educación y valores, y principalmente a mi madre por aguantarme, apoyarme, animarme y en todo momento creer en mí. A mi hermana por todas las veces que, pese a su insistencia, he decidido dedicarle tiempo a esta tesis en vez de a ella, y a mis abuelos y mi tía por ser mis mayores admiradores. 



\section{Contents}

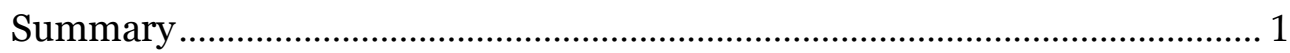

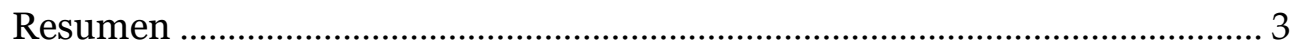

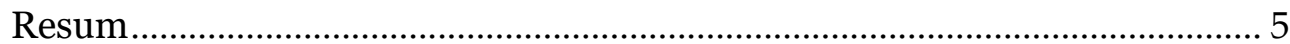

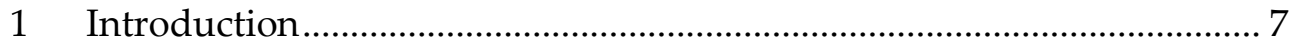

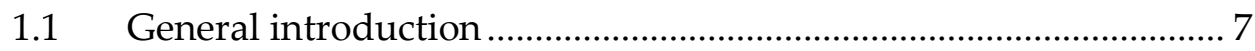

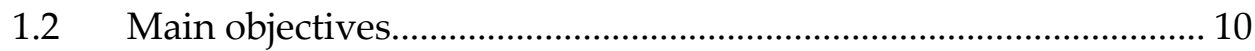

$1.3 \quad$ Specific objectives ........................................................................ 11

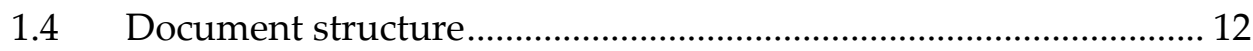

2 Modelling the nitrogen cycle .................................................................. 13

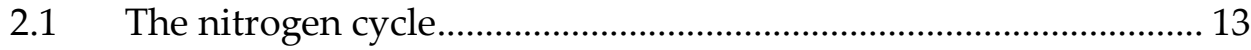

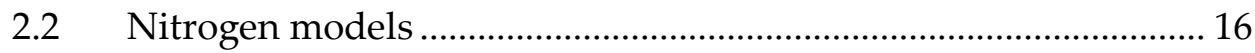

3 La Hunde forest: a natural ecosystem ................................................. 21

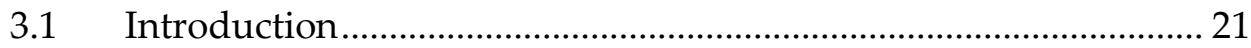

3.2 A brief introduction to facultative phreatophytes .......................... 24

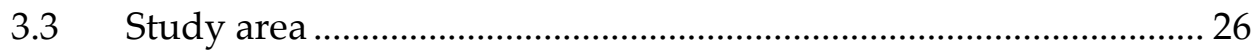

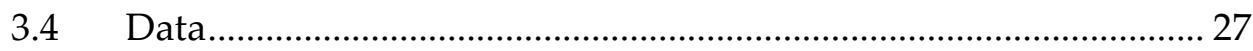

3.4.1 Meteorological data and hydrological field measurements .. 27

3.4.2 Soil carbon and nitrogen field measurements ......................... 30

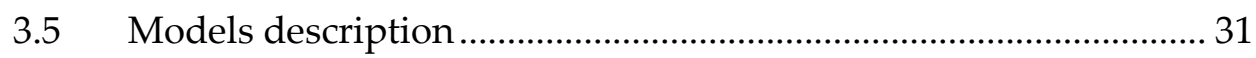

3.5.1 BIOME-BGCMuSo model........................................................ 31

3.5.2 LEACHM model ....................................................................... 33

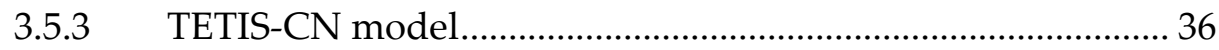


3.6 Methodology for model implementation 43

3.6.1 Model evaluation..................................................................... 44

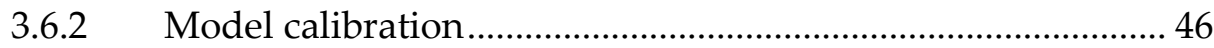

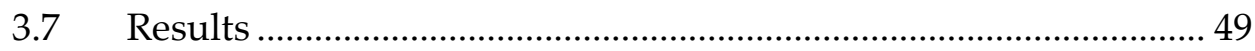

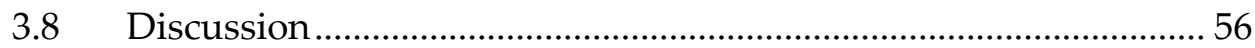

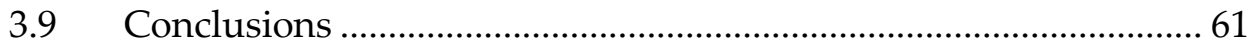

4 El Mar Menor watershed: an anthropogenic ecosystem ........................ 65

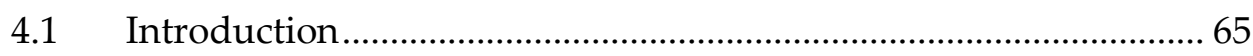

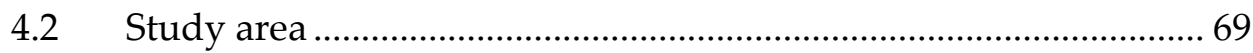

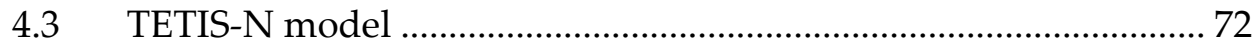

4.3.1 Hydrological sub-model ......................................................... 72

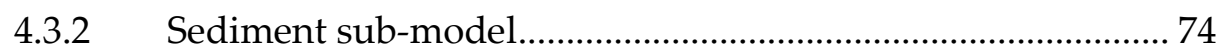

4.3.3 Nitrogen sub-model ............................................................... 75

4.3.4 Model parameters and split-parameter structure ................... 79

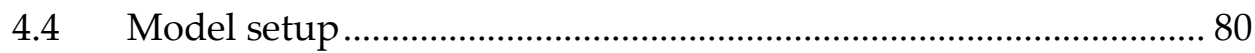

4.4.1 Initial parameter estimation ...................................................... 80

4.4.2 Model inputs .............................................................................. 85

4.5 Model implementation ................................................................. 87

4.6 Best management practices scenarios and model representation 91

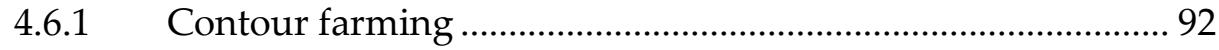

4.6.2 Contour farming and grassy field borders............................... 93

4.6.3 Contour farming and hedgerow field borders ........................ 94

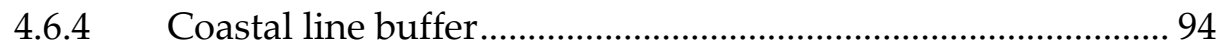

4.6.5 Fertilizer management ................................................................ 95 
4.6.6 Fertilizer management and two-crop rotation ........................ 97

$4.7 \quad$ Results and discussion ................................................................. 98

4.7.1 Model implementation: baseline scenario................................. 98

4.7.2 Evaluation of best management practices scenarios ............. 103

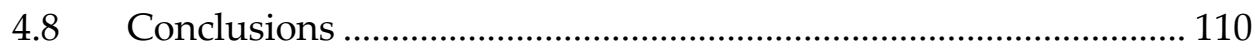

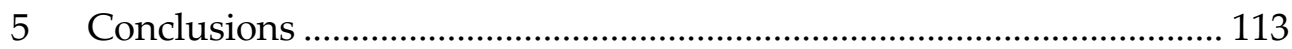

5.1 Concluding remarks..................................................................... 113

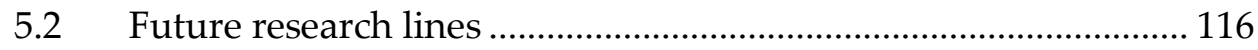

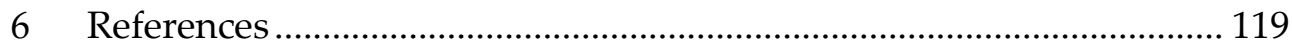

A. Plot scale models parameters............................................................... 151

B. TETIS-N model parameters................................................................... 161

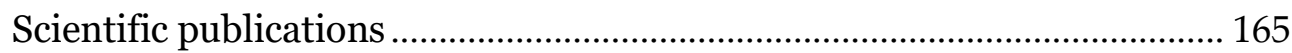





\section{List of figures}

Figure 2-1 I Schematic representation of the nitrogen cycle. 14

Figure 2-2 I Published items with the terms "nitrogen modelling" in the title, abstract or keywords. 16

Figure 2-3 | Published items with the terms "nitrogen modelling", "forest" and "agriculture" respectively, in the title, abstract or keywords. 17

Figure 3-1 I Location of the experimental plot study site. 27

Figure 3-2 I Observed soil water content and transpiration series. 29

Figure 3-3 | Schema of the adapted hydrological sub-model of TETIS-CN.

Figure 3-4 | Schema of the carbon and nitrogen sub-model of TETIS-CN. 41

Figure 3-5 I Heatmap representation of soil water content and weekly transpiration NS indices.

Figure 3-6 | Observed and simulated soil water content. .49

Figure 3-7 | Observed and simulated weekly transpiration. 50

Figure 3-8 | Heatmap representation of accumulated net mineralization, accumulated net nitrification, $\mathrm{N}-\mathrm{NH}_{4}{ }^{+}$soil content, $\mathrm{N}-\mathrm{NO}_{3}{ }^{-}$soil content, accumulated mineral nitrogen leaching and heterotrophic soil respiration RMSE indices. 52

Figure 3-9 | Spatially averaged observed values and simulated values of accumulated mineralization. 52

Figure 3-10 I Spatially averaged observed values and simulated values of accumulated nitrification. 53

Figure 3-11 I Spatially averaged observed values and simulated values of N$\mathrm{NH}_{4}{ }^{+}$soil content. .53

Figure 3-12 I Spatially averaged observed values and simulated values of N$\mathrm{NO}_{3}{ }^{-}$soil content. 54 
Figure 3-13 I Spatially averaged observed values and simulated values of heterotrophic respiration. 54

Figure 3-14 I Mineralization, nitrification, $\mathrm{N}_{-} \mathrm{NH}_{4}{ }^{+}$soil content and $\mathrm{N}^{-\mathrm{NO}_{3}}{ }^{-}$ soil content box plots of the spatial and temporal observed values and temporal simulated values. 55

Figure 3-15 I Spatially averaged observed values and simulated values of accumulated mineral nitrogen leaching........................................................ 55

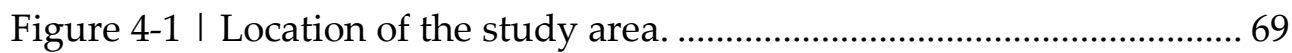

Figure 4-2 | Digital elevation model of the study area................................. 70

Figure 4-3 I Simplified land use map of the study area (CORINE Land Cover 2006). 71

Figure 4-4 | Vertical hydrological conceptualization of TETIS-N................ 73

Figure 4-5 | Horizontal hydrological conceptualization of TETIS-N........... 73

Figure 4-6 | Sediment conceptualization of TETIS-N. ……............................ 74

Figure 4-7 | Nitrogen conceptualization of TETIS-N. ................................... 78

Figure 4-8 | Maximum static storage of the study area. Values in mm....... 81

Figure 4-9 I Infiltration capacity at saturation of the study area. Values in

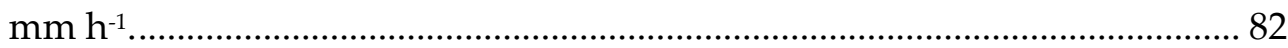

Figure 4-10 | Percolation capacity of the study area. Values in $\mathrm{mm} \mathrm{h}^{-1}$..... 82 Figure 4-11 I K-factor values of the study area. Values in $\mathrm{Mg} \mathrm{m}^{2} \mathrm{~h} \mathrm{ha}^{-1} \mathrm{hJ}^{-1} \mathrm{~cm}^{-}$ 1 .83

Figure 4-12 I C-factor values of the study area (dimensionless). 83

Figure 4-13 I Soil organic nitrogen content. Values in $\mathrm{kgN} \mathrm{m}^{-3}$. 84

Figure 4-14 I Fertilizer doses. Golf course, citrus trees and horticultural crops land uses. 86

Figure 4-15 I Basin used to calibrate the hydrological and sediment submodels. 
Figure 4-16 I Land use maps of the CB100 and CB500 scenarios (Corine Land Cover 2006). Zoom to the coastal line. .95

Figure 4-17 I Flood frequency analysis results. 98

Figure 4-18 | Observed and simulated monthly total evapotranspiration. 99 Figure 4-19 | Total nitrogen leaching for the baseline scenario. Values in kgN ha $^{-1}$ year $^{-1}$. 102

Figure 4-20 | Surface nitrogen export $\left(\mathrm{kgN} \mathrm{ha}^{-1}\right.$ year-1), nitrogen leaching $\left(\mathrm{kgN} \mathrm{ha}^{-1}\right.$ year-1), sediment yield $\left(\mathrm{Mg} \mathrm{ha}^{-1}\right.$ year $\left.^{-1}\right)$ and crop dry matter yield $\left(\mathrm{Mg} \mathrm{ha}^{-1}\right.$ year $\left.^{-1}\right)$ for each management practice scenario and the baseline scenario. $\mathrm{CF}$ is contour farming, $\mathrm{CF}+\mathrm{GFB}$ is contour farming and grassy field borders, $\mathrm{CF}+\mathrm{HFB}$ is contour farming and hedgerow field borders, CB100 is $100 \mathrm{~m}$ coastal line buffer, CB500 is $500 \mathrm{~m}$ coastal line buffer, FM is fertilizer management and $\mathrm{FM}+\mathrm{CR}$ is fertilizer management and two-crop rotation. 103

Figure 4-21 | Crop yield percentage reductions for each management practice scenario. $\mathrm{CF}$ is contour farming, $\mathrm{CF}+\mathrm{GFB}$ is contour farming and grassy field borders, $\mathrm{CF}+\mathrm{HFB}$ is contour farming and hedgerow field borders, CB100 is $100 \mathrm{~m}$ coastal line buffer, CB500 is $500 \mathrm{~m}$ coastal line buffer, $\mathrm{FM}$ is fertilizer management and FM+CR is fertilizer management and twocrop rotation. 105

Figure 4-22 I Surface nitrogen export percentage reductions for each management practice scenario. $\mathrm{CF}$ is contour farming, $\mathrm{CF}+\mathrm{GFB}$ is contour farming and grassy field borders, $\mathrm{CF}+\mathrm{HFB}$ is contour farming and hedgerow field borders, CB100 is $100 \mathrm{~m}$ coastal line buffer, CB500 is $500 \mathrm{~m}$ coastal line buffer, $\mathrm{FM}$ is fertilizer management and $\mathrm{FM}+\mathrm{CR}$ is fertilizer management and two-crop rotation. 107

Figure 4-23 I Nitrogen leaching percentage reductions for each management practice scenario. $\mathrm{CF}$ is contour farming, $\mathrm{CF}+\mathrm{GFB}$ is contour farming and grassy field borders, $\mathrm{CF}+\mathrm{HFB}$ is contour farming and hedgerow field borders, CB100 is $100 \mathrm{~m}$ coastal line buffer, CB500 is $500 \mathrm{~m}$ coastal line buffer, 
FM is fertilizer management and FM+CR is fertilizer management and two-

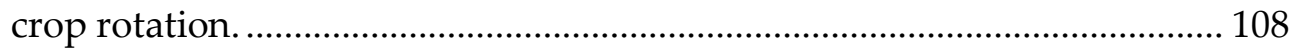

Figure 4-24 I Total nitrogen leaching for the FM (fertilizer management)

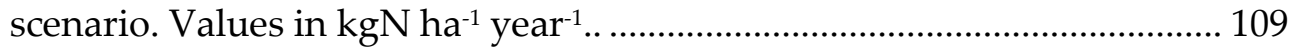
Figure 4-25 I Total nitrogen leaching for the FM+CR (fertilizer management and two-crop rotation) scenario. Values in $\mathrm{kgN} \mathrm{ha}^{-1} \mathrm{year}^{-1} \ldots \ldots \ldots \ldots \ldots \ldots \ldots \ldots . . . . . . . . . . .109$ 


\section{List of tables}

Table 3-1 | Soil characteristics of the study site. SOC means soil organic carbon. Particle fractions (texture) in the following order: sand, silt and clay (\%). (Bautista et al., 2015; del Campo et al., 2018).

27

Table 3-2 I Type, temporal availability and temporal model use for each measurement. 28

Table 3-3 | Model characteristics comparison. 32

Table 3-4 I Mean annual water balances in the soil (2012-2015). 50

Table 3-5 | Relative contributions of groundwater transpiration to total transpiration, summer transpiration and total evapotranspiration. 51

Table 3-6 I Mean annual carbon and nitrogen balances in the first $15 \mathrm{~cm}$ of soil (2012-2014). 56

Table 4-1 | Area (\%) for each land use in the study area............................. 71

Table 4-2 I Current annual fertilizer doses. Values in $\mathrm{kgN} \mathrm{ha}^{-1} \mathrm{year}^{-1}$. 87

Table 4-3 | Final P-factor and $P_{c}, P_{s w}$ and $P_{v m}$ sub-factors values in the horticultural crops land use. CF is contour farming, CF+GFB is contour farming and grassy field borders and $\mathrm{CF}+\mathrm{HFB}$ is contour farming and hedgerow field borders. .93

Table 4-4 I Nitrogen mass balance for each crop and scenario. Values expressed in $\mathrm{kgN} \mathrm{ha}^{-1}$ year-1. $^{\mathrm{FM}}$ is fertilizer management and $\mathrm{FM}+\mathrm{CR}$ is fertilizer management and two-crop rotation. .96

Table 4-5 I Annual fertilizer doses for each crop and scenario. Fertilizer values expressed in $\mathrm{kgN} \mathrm{ha}^{-1} \mathrm{year}^{-1}$. FM is fertilizer management and FM+CR is fertilizer management and two-crop rotation. 97 Table 4-6 I Calculated and simulated volume of the 25-year return period hydrograph. .99 
Table 4-7 I Calculated mean annual erosion rate and values of the USLE factors 99

Table 4-8 | Calculated and simulated mean annual erosion rate. 100

Table 4-9 I Estimated and simulated mean annual potential nitrogen uptake for the simplified land uses. Values in parenthesis represent volume error.

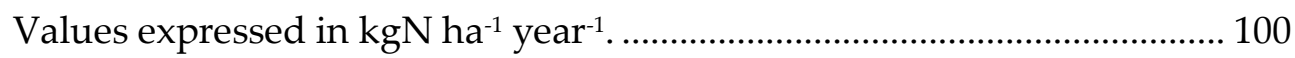

Table 4-10 I Estimated crop yield target and simulated crop yield (dry matter). Values in parenthesis represent volume error. Values are expressed in $\mathrm{Mg} \mathrm{ha}^{-1}$ year $^{-1}$. 101

Table 4-11 | Baseline scenario long-term mean annual balances on the soil. 


\section{Summary}

Nitrogen is a fundamental component of living organisms, but it is also in short supply in forms in which vegetation can assimilate. As a result, nitrogen is a limiting element for vegetation growth. However, as a consequence of the human-mediated introduction of mineral nitrogen, nitrogen is also a major pollutant in anthropogenic ecosystems. Both natural and anthropogenic ecosystems supply important goods and services for the human wellbeing and in order to maintain the human living standards, there is a necessity of preserving natural ecosystems over time on one side, while improving the sustainability of anthropogenic ecosystems on the other. In that sense, mathematical models including the nitrogen cycle are useful tools which allow the analysis of the relationships and behaviours of these ecosystems, and there is a clear need to continue to develop and test nitrogen models, principally, models with an integrated approach, capable to deal with the different characteristics and behaviours of natural and anthropogenic ecosystems.

Hence, the aim of the present thesis is to improve the nitrogen cycle modelling, exploring different parsimonious modelling approaches within the plant-soil-water continuum in natural and anthropogenic semiarid ecosystems. To face this objective, two parsimonious nitrogen models have been developed and implemented in two different data availability scenarios.

Firstly, a new parsimonious carbon and nitrogen model, TETIS-CN, is implemented in a semiarid natural forest ecosystem trying to contribute to a better understanding and modelling of the hydrological and biogeochemical (carbon and nitrogen) cycles and their interactions in semiarid conditions and to test its capability to satisfactorily reproduce them. The results are satisfactory and suggest that it is important to include carbon observations 
Exploring the possibilities of parsimonious nitrogen modelling in different ecosystems

in the calibration process, to consider all the existing vegetation species in the simulation, and that a fixed daily potential uptake may not be appropriate to reproduce the plant nitrogen uptake process. Secondly, a new parsimonious nitrogen model, TETIS-N, is implemented in a semiarid anthropogenic agricultural ecosystem. Since agriculture is the major source of diffuse pollution, being nitrogen and sediment pollution of water bodies its main associated environmental impacts, this second approach aims to improve its sustainability by evaluating the impact of several management practices on nitrogen and sediment loads, and horticultural crop yields. As a result, each management practice resulted effective in reducing a certain type of diffuse pollution, and therefore, combined scenarios are necessary to cope with all agricultural pollution sources.

This thesis proved that each ecosystem has different characteristics and behaviours and therefore, different modelling necessities. Consequently, current models should include an integrate modelling of both natural and anthropogenic ecosystems. 


\section{Resumen}

El nitrógeno es un componente fundamental de los organismos vivos, pero también es escaso en las formas en que la vegetación puede asimilarlo, lo que lo convierte en un elemento limitante para el crecimiento de la vegetación. Sin embargo, debido a la introducción de nitrógeno mineral por el hombre, también se ha convertido en un contaminante importante en los ecosistemas. Tanto los ecosistemas naturales como los antrópicos, suministran bienes y servicios importantes $\mathrm{y}$, para poder mantener los niveles de vida, es necesario preservar los ecosistemas naturales, por un lado, y mejorar la sostenibilidad de los ecosistemas antrópicos por otro. De esta forma, los modelos matemáticos que incluyen la modelización del ciclo de nitrógeno son herramientas útiles que permiten el análisis de las relaciones y los comportamientos de estos ecosistemas. Por lo que existe una clara necesidad de continuar desarrollando y probando nuevos modelos de nitrógeno, principalmente con un enfoque integrado, capaces de abordar las diferentes características y comportamientos de los ecosistemas naturales y antrópicos.

De esta forma, el objetivo de esta tesis es mejorar la modelización del ciclo de nitrógeno, explorando diferentes enfoques de modelización parsimoniosa dentro del continuo planta-suelo-agua en ecosistemas semiáridos naturales y antrópicos. Para abordar este objetivo, se han desarrollado e implementado dos modelos de nitrógeno parsimoniosos en dos escenarios diferentes

En primer lugar, se ha desarrollado e implementado un nuevo modelo parsimonioso de carbono y nitrógeno, TETIS-CN, en un ecosistema de bosque natural semiárido. Este primer enfoque intenta contribuir a una mejor comprensión y modelización de los ciclos hidrológico y biogeoquímicos (carbono y nitrógeno) y de sus interacciones en condiciones semiáridas. Así mismo, se comprueba la capacidad del modelo propuesto para reproducirlos satisfactoriamente. Los resultados son satisfactorios y 
Exploring the possibilities of parsimonious nitrogen modelling in different ecosystems sugieren que es importante incluir observaciones de carbono en el proceso de calibración, considerar todas las especies de vegetación existentes en la simulación, y que una absorción potencial diaria fija puede no ser apropiada para reproducir el proceso de absorción de nitrógeno por parte de la vegetación. En segundo lugar, se ha desarrollado e implementado un nuevo modelo de nitrógeno parsimonioso, TETIS-N, en un ecosistema agrícola antrópico semiárido. Dado que la agricultura es la principal fuente de contaminación difusa, siendo la contaminación por nitrógeno y sedimentos de las masas de agua, su principal impacto ambiental, este segundo enfoque tiene como objetivo evaluar el impacto de varias prácticas de gestión en las descargas de nitrógeno y sedimentos, así como en la producción de los cultivos hortícolas. Como resultado, cada práctica de gestión resulta efectiva en la reducción de cierto tipo de contaminación difusa y, por lo tanto, se necesitan escenarios combinados para hacer frente a todas las fuentes de contaminación agrícola.

Esta tesis ha demostrado que cada ecosistema tiene diferentes características y comportamientos y, por lo tanto, diferentes necesidades de modelización, por lo que los modelos actuales deben incluir una modelización integrada de los ecosistemas naturales y antrópicos. 


\section{Resum}

El nitrogen és un component fonamental dels organismes vius, però també és escàs en les formes en què la vegetació pot assimilar-ho, convertint-lo en un element limitant per al creixement de la vegetació. No obstant, a causa de la introducció de nitrogen mineral per l'home, també s'ha convertit en un contaminant important als ecosistemes. Tant els ecosistemes naturals com els antròpics, subministren béns i serveis importants $i$, per a poder mantenir els nivells de vida, és necessari preservar els ecosistemes naturals, d'una banda, i millorar la sostenibilitat dels ecosistemes antròpics per altra. D'aquesta forma, els models matemàtics que inclouen la modelització del cicle del nitrogen són eines útils que permeten l'anàlisi de les relacions i els comportaments d'aquests ecosistemes. Per tant, existeix una clara necessitat de continuar desenvolupant i provant nous models de nitrogen, principalment amb un enfocament integrat, capaços $d^{\prime}$ abordar les diferents característiques i comportaments dels ecosistemes naturals i antròpics.

D'aquesta forma, l'objectiu d'aquesta tesi és millorar la modelització del cicle del nitrogen, explorant diferents enfocaments de modelització parsimoniosa dins del continu planta-sòl-aigua en ecosistemes semiàrids naturals i antròpics. Per a abordar aquest objectiu, s'han desenvolupat i implementat dos models de nitrogen parsimoniosos en dos escenaris diferents.

En primer lloc, s'ha desenvolupat i implementat un nou model parsimoniós de carboni i nitrogen, TETIS-CN, en un ecosistema de bosc natural semiàrid. Aquest primer enfocament intenta contribuir a una millor comprensió i modelització dels cicles hidrològic i biogeoquímics (carboni i nitrogen) i de les seues interaccions en condicions semiàrides. Així mateix, comprova la capacitat del model proposat per a reproduir-los satisfactòriament. Els resultats són satisfactoris i suggereixen que és important incloure observacions de carboni en el procés de calibratge, considerar totes les 
Exploring the possibilities of parsimonious nitrogen modelling in different ecosystems espècies de vegetació existents en la simulació, i que una absorció potencial diària fixa pugues no ser apropiada per a reproduir el procés d'absorció de nitrogen per part de la vegetació. En segon lloc, s'ha desenvolupat i implementat un nou model de nitrogen parsimoniós, TETIS-N, en un ecosistema agrícola antròpic semiàrid. Atès que l'agricultura és la principal font de contaminació difusa, sent la contaminació per nitrogen i sediments de les masses d'aigua, el seu principal impacte ambiental, aquest segon enfocament té com a objectiu avaluar l'impacte de diverses pràctiques de gestió en les descàrregues de nitrogen i sediments, així com en la producció dels cultius hortícoles. Com a resultat, cada pràctica de gestió resulta efectiva en la reducció de cert tipus de contaminació difusa i, per tant, es necessiten escenaris combinats per a fer front a totes les fonts de contaminació agrícola.

Aquesta tesi ha demostrat que cada ecosistema té diferents característiques i comportaments i, per tant, diferents necessitats de modelització, per tant, els models actuals han d'incloure una modelització integrada dels ecosistemes naturals i antròpics. 


\section{1 \\ Introduction}

\subsection{General introduction}

Nitrogen is a fundamental component of living organisms, nevertheless, it is also in short supply in forms in which vegetation can assimilate (Gruber and Galloway, 2008). For example, nitrogen is the main component of the atmosphere (78\% approximately) but diatomic nitrogen is unavailable to most organisms (Galloway et al., 2004). As a result, nitrogen is a limiting element for vegetation growth, and especially, in the semiarid Mediterranean region, where soils are often nutrient poor (Sardans and Rodà, 2004). However, as a consequence of the human-mediated introduction of mineral nitrogen, nitrogen is also a major pollutant in anthropogenic ecosystems (Gruber and Galloway, 2008). 
Exploring the possibilities of parsimonious nitrogen modelling in different ecosystems

Both natural and anthropogenic ecosystems supply important goods and services for the human wellbeing. Grasslands and forests provide harvestable products, regulate climate, the hydrological and mineral cycles, protect soil from erosion and prevent floods (Kozlowski, 2002), while intensive agriculture provides food, fibre, feed and biofuel (Tilman et al., 2002). However, these ecosystems present very different behaviours, principally in terms of mineral nitrogen availability and, in fact, agricultural watersheds export four times more total nitrogen than forested watersheds (Alvarez-Cobelas et al., 2008).

In natural ecosystems mineral nitrogen availability is markedly linked to the microbial activity because mineral nitrogen is the result of the microbial decomposition of organic matter and, as most of the annual nutrient requirements are supplied from decomposition (Aponte et al., 2010), nitrogen becomes a limiting element. This is particularly true in semiarid ecosystems, where soil water content is a major environmental factor (Manzoni et al., 2004; Rodrigo et al., 1997) which enhances some processes and quenches others (Lupon et al., 2015), making the interactions between vegetation, soil water content and nutrients highly complicated (Wang et al., 2018). Accordingly, nitrogen is also a limiting element for the crops cultivated by humans for food. Nevertheless, in 1909, Fritz Haber succeeded in determining how to synthesize ammonia from its elements (Smil, 1999), process later known as the Haber-Bosch process, and hence, nitrogen is not necessarily a limiting element in agricultural land anymore. In fact, by 1970s, the anthropogenic nitrogen addition to human managed ecosystems became more important than the biological nitrogen fixation in natural ecosystems (Galloway et al., 2013), rendering nitrogen a major pollutant of water bodies and the atmosphere.

Therefore, in order to maintain the human living standards, there is a necessity of preserving natural ecosystems over time on one side (Bengtsson 
et al., 2000), while improving the sustainability of anthropogenic ecosystems on the other (Pradhan et al., 2015). Specially, in the Mediterranean region, which has shown a negative precipitation trend throughout the $20^{\text {th }}$ century (Cook et al., 2018) and stands out in climate change projections as an area where total drought severity increases in either scenario (Spinoni et al., 2018).

On the one hand, alterations in water, carbon and nitrogen cycles are expected (Dong et al., 2019). For example, the decoupling of the carbon and nitrogen cycles (Delgado-Baquerizo et al., 2013) or changes in its supply, which will impact ecosystems productivity, biological diversity and even plant competition (Fowler et al., 2013), because plant competition increases in resource-limited environments (Calama et al., 2019). On the other hand, the use of fertilizers is expected to increase due to the growing needs of food, fibre, feed and biofuel as a consequence of population growth and the improvement in living standards (Chukalla et al., 2018; Tilman et al., 2011), and additionally, climate change is expected to have an impact on hydrology and diffuse nutrient export from agricultural areas (Wagena and Easton, 2018).

Therefore, there are important consequences of the human disturbance of the nitrogen cycle, with benefits in food production but global, regional and local environmental problems (Lin et al., 2001). As a result, the nitrogen storage, transport and transformation has become a priority for the hydrological community (Schlesinger et al., 2006), and in that sense, mathematical models including the nitrogen cycle are useful tools which allow the analysis of the relationships and behaviours of these ecosystems (Landsberg, 2003). Nevertheless, there is a clear need to continue to develop and test nitrogen models (Neal et al., 2002), and principally, models with an integrated approach, capable to deal with the different characteristics and behaviours of natural and anthropogenic ecosystems. 


\subsection{Main objectives}

As previously introduced, there is a need for nitrogen models especially suited to be applied in semiarid environments that integrate both natural and anthropogenic ecosystems characteristics and behaviours. This is the reason why the Research Group of Hydrological and Environmental Modelling, in which this thesis was developed, started this research line with the contribution of Medici (2010), who focused on identifying and quantifying the key nitrogen processes taking place in semiarid environments.

Continuing with this research line, this new thesis aims to improve the nitrogen cycle modelling under the principle that everything should be made as simple as possible, but not simpler (Stocker et al., 2016). It targets exploring different parsimonious approaches to model de nitrogen cycle within the plant-soil-water continuum in natural and anthropogenic semiarid ecosystems, and it attempts to understand how the nitrogen cycle interacts with water, vegetation and sediments and how these interactions can be modelled. To face these objectives, a progressive understanding approach consisting in the nitrogen cycle modelling in two different data availability scenarios was adopted.

The first approach focuses on a semiarid natural forest ecosystem, mainly dominated by facultative phreatophytes. Mediterranean natural ecosystems are nitrogen limited (Sardans et al., 2008; Uscola et al., 2017) and a better knowledge of its storage and cycling is crucial to preserve them. However, there is a strong relation between microbial activity and mineral nitrogen release, which biologically couples the carbon and nitrogen cycles (Gleeson et al., 2016; Lucas-Borja et al., 2019; Pastor and Post, 1986). Therefore, the modelling of the nitrogen cycle in natural ecosystems leads to the incorporation of the carbon cycle, which controls nitrogen mineralization, main mineral nitrogen input in these ecosystems. 
The second approach is developed in an intensive irrigated agricultural watershed under a semiarid climate. These areas are characterized by an elevated use of fertilizers (Pardo et al., 2017; Poch-Massegú et al., 2014), and hence, improving their sustainability is essential. Conversely, the main mineral nitrogen input is not the natural nitrogen mineralization but the fertilization process. For this reason, the modelling of the nitrogen cycle in these areas can be decoupled from the modelling of the carbon cycle and all the carbon-related parameters replaced by a mineralization constant. Moreover, soil erosion in semiarid agricultural areas is usually high (Durán Zuazo et al., 2006), and as agricultural soils are rich in nitrogen (García-Ruiz et al., 2015; Merchán et al., 2018), the nitrogen transport associated to soil erosion is noteworthy, which leads to the consideration of the sediment cycle.

\subsection{Specific objectives}

These two approaches also present specific objectives. The first approach specifically aims to contribute to a better understanding and modelling of the nitrogen cycle in natural ecosystems, and due to its linkage to the carbon cycle, the modelling of the carbon cycle and their interactions within the soilplant continuum in semiarid conditions. Secondly, it also aims to test the capability of the proposed model to satisfactorily reproduce them.

The objective of the second approach is dual. Firstly, it aims to evaluate the impact of several management practices on nitrogen and sediment loads, as well as their impact on horticultural crop yield. Secondly, it also aims to serve as a springboard to identify an appropriate management strategy at the watershed scale, which will be useful to be applied to another watershed with similar characteristics and similar problems, being of particular interest to stakeholders and policy makers. 


\subsection{Document structure}

In order to cover the abovementioned objectives, this thesis is structured as follows. Chapter 1 sets the basis of the research, outlining the general framework and defining the main objectives to be addressed. Chapter 2 gives a general introduction to the nitrogen cycle and a literature review in the field of nitrogen models in natural forest and anthropogenic agricultural ecosystems. Chapters 3 and 4 present the case studies, with a specific and detailed introduction and conclusion. The former focuses on a semiarid natural forest ecosystem and the latter on a semiarid anthropogenic agricultural ecosystem. Finally, chapter 5 contains the main conclusions and future research lines. 


\section{2}

\section{Modelling the nitrogen cycle}

\subsection{The nitrogen cycle}

There are three major forms of nitrogen in soils: (1) organic nitrogen, (2) ammonium $\left(\mathrm{NH}_{4}{ }^{+}\right)$and (3) nitrate $\left(\mathrm{NO}_{3}^{-}\right)$; nonetheless, the nitrogen cycle is characterized by many complex transformations. Figure 2-1 shows a schematic representation of the main components of the soil nitrogen cycle. The nitrogen inputs to the soil are animal, vegetation and human residues and wastes, commercial fertilizers, fixation and wet and dry deposition. The nitrogen outputs are leaching, runoff, erosion, vegetation uptake, crop harvest and gaseous losses.

The information of this section was extracted from Weil and Brady (2017). 


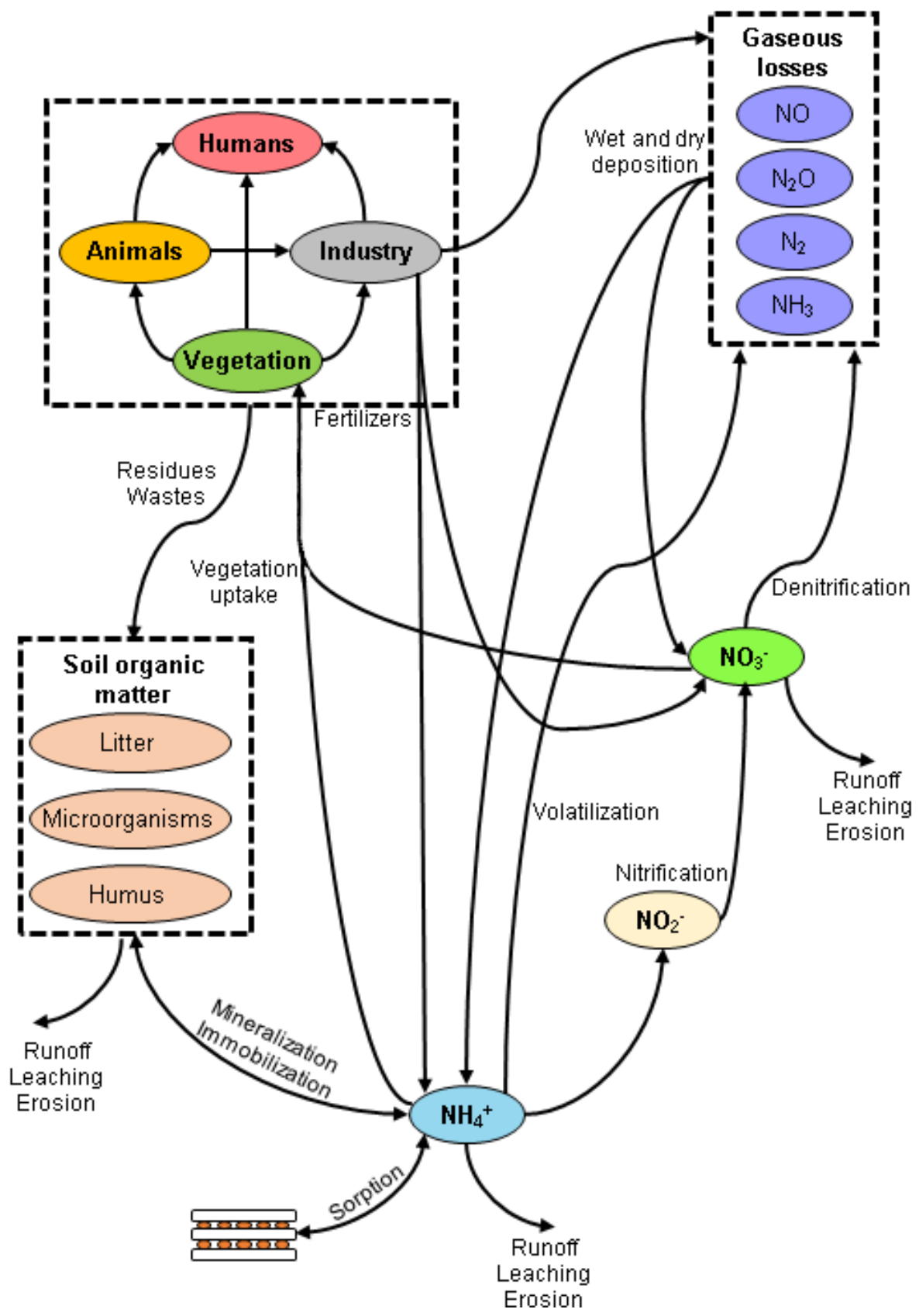

Figure 2-1 I Schematic representation of the nitrogen cycle.

Animal and vegetation residues and wastes (i.e., litter) are the main natural nitrogen input to the soil, where they become part of the soil organic matter. 
Decomposition of soil organic matter gives rise to $\mathrm{NH}_{4}{ }^{+}$and biologically couples the carbon and nitrogen cycles, because soil microorganisms control nitrogen mineralization. This process of microbial decomposition is divided into mineralization and immobilization processes. Microorganisms require a fixed C:N ratio, therefore, if soil organic matter presents a high nitrogen content, decomposition gives rise to $\mathrm{NH}_{4}{ }^{+}$(i.e., mineralization), however, if soil organic matter is nitrogen poor, microorganisms are able to use mineral nitrogen (i.e., immobilization).

Nitrification is the result of the $\mathrm{NH}_{4}{ }^{+}$oxidation to $\mathrm{NO}_{3}$. In this process, $\mathrm{NH}_{4}{ }^{+}$ is oxidized to nitrite $\left(\mathrm{NO}_{2}{ }^{-}\right)$and almost immediately, it is oxidized to $\mathrm{NO}_{3}$ Under favourable conditions of soil temperature and soil moisture, nitrification is quite rapid, which is very important, since $\mathrm{NO}_{2}^{-}$is very toxic.

Both $\mathrm{NH}_{4}{ }^{+}$and $\mathrm{NO}_{3}{ }^{-}$return to the atmosphere in gaseous form. On the one hand, $\mathrm{NH}_{4}{ }^{+}$hydrolizes to ammonia $\left(\mathrm{NH}_{3}\right)$ and $\mathrm{NH}_{3}$ is lost to the atmosphere. This process is known as volatilization and it is highly influenced by the soil $\mathrm{pH}$, being especially important on alkaline soils. On the other hand, $\mathrm{NO}_{3}{ }^{-}$is subject to reduction by the microorganisms in soils, process known as denitrification. Under poorly drained soils, the microorganisms use the combined oxygen in $\mathrm{NO}_{3}{ }^{-}$, releasing nitric oxide $(\mathrm{NO})$, nitrous oxide $\left(\mathrm{N}_{2} \mathrm{O}\right)$ and elemental nitrogen $\left(\mathrm{N}_{2}\right)$ to the atmosphere (i.e., greenhouse nitrogen gases). Both processes are more prone to occur in agricultural soils due to the elevated use of fertilizers and soil moisture levels. Some of these gaseous compounds return to the soil through the wet and dry deposition.

Although organic nitrogen is the largest pool of nitrogen in the soil, it is generally unavailable to vegetation because vegetation almost only uptake nitrogen in its mineral form (i.e., $\mathrm{NH}_{4}{ }^{+}$and $\mathrm{NO}_{3}{ }^{-}$). Vegetation meets its nitrogen requirements by two different mechanisms: passive uptake, through the transpiration process, and active uptake, through a diffusive flux if the nitrogen requirement is higher than the passive uptake. 
Exploring the possibilities of parsimonious nitrogen modelling in different ecosystems

Finally, $\mathrm{NH}_{4}{ }^{+}$and $\mathrm{NO}_{3}{ }^{-}$can be lost by leaching or surface runoff at high soil moisture levels. $\mathrm{NO}_{3}{ }^{-}$is easily soluble in water, and consequently is more prone to be lost by leaching and surface runoff. However, $\mathrm{NH}_{4}{ }^{+}$ions present positive charge, which attracts them to the negatively charged surfaces of clays and humus, partially protecting them from leaching and impeding nitrogen uptake. Soil erosion mainly affects sorbed $\mathrm{NH}_{4}{ }^{+}$and organic nitrogen.

\subsection{Nitrogen models}

Mathematical models are useful tools for land management decision support in different scenarios, and consequently its use is increasing. Specifically, the nitrogen turnover has been studied for more than two centuries (Golubyatnikov et al., 2013) and the use of nitrogen models has strongly increased since the early 60's until now (Figure 2-2), with a greater interest in agricultural areas than in natural areas (Figure 2-3).

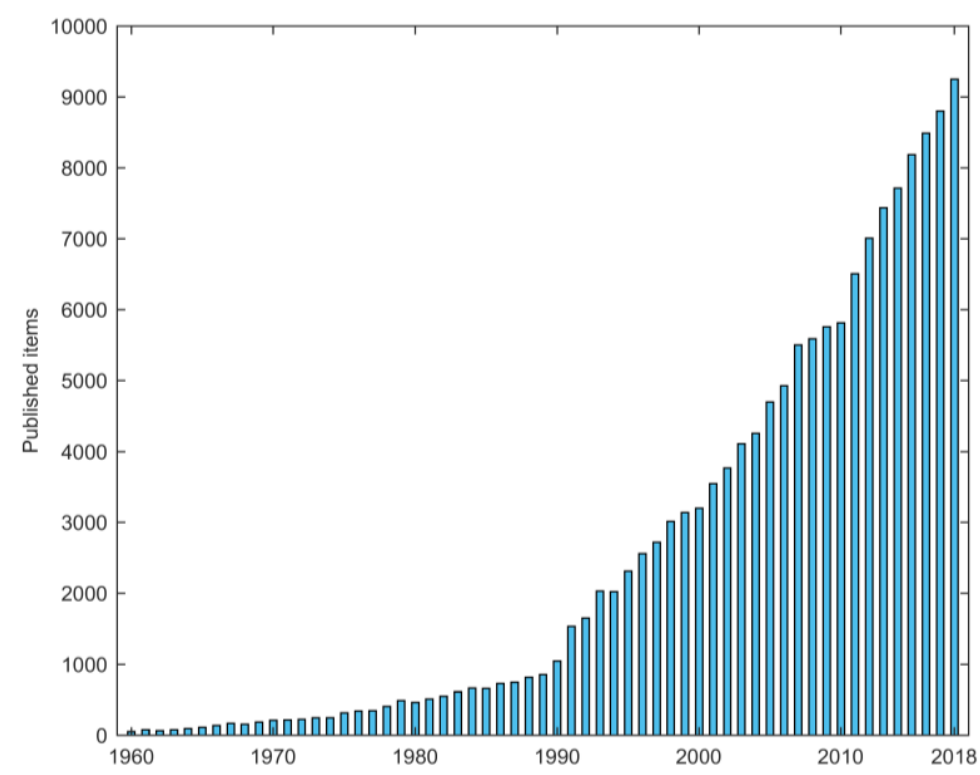

Figure 2-2 | Published items with the terms "nitrogen modelling" in the title, abstract or keywords. 


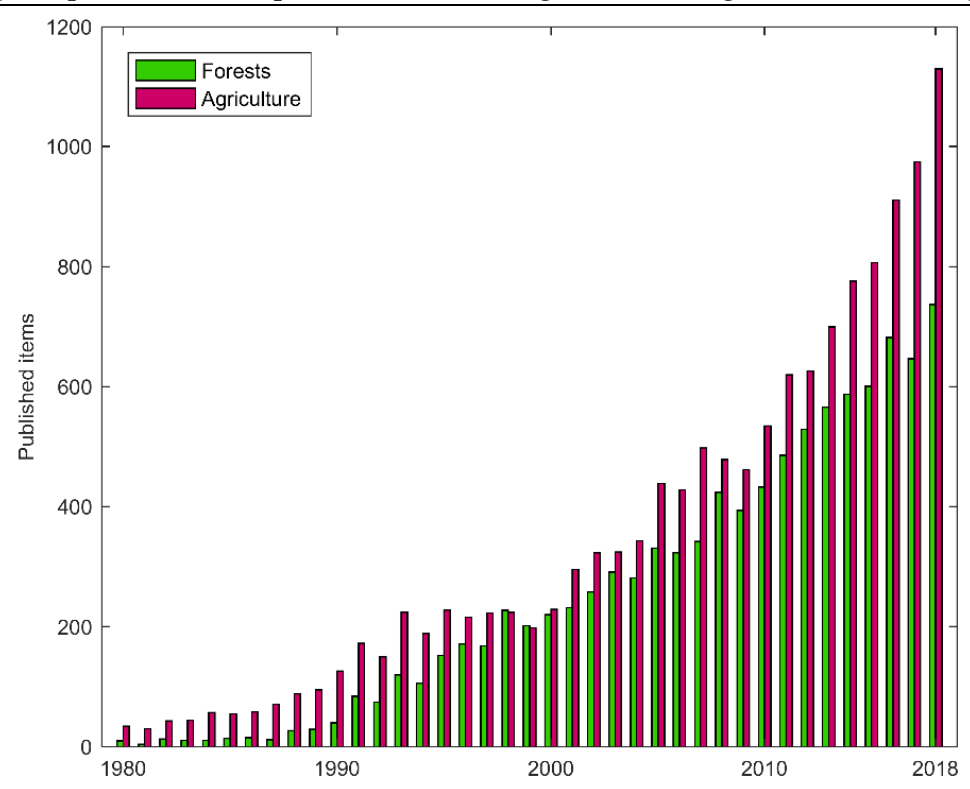

Figure 2-3 I Published items with the terms "nitrogen modelling", "forest" and "agriculture" respectively, in the title, abstract or keywords.

Two kind of models can be distinguished depending on the spatial scale: field or plot scale models and watershed scale models. The former are usually more complex models, parameterized for an individual specie or plant functional type, while the latter are simpler, dividing the area into cells, downscaling the environmental variables to each cell, simulating the state variable in each cell and then assembling the results for the watershed.

Numerous plot scale biogeochemical models have been developed for both natural forest ecosystems and anthropogenic agricultural ecosystems. These models are usually physically- or process-based and have an accurate representation of the hydrological, carbon and nitrogen cycles, which makes both forest and agricultural ecosystem models especially suited for environmental assessment, as a basis for policy and decision-making (Kersebaum et al., 2015; Vanderwel et al., 2013). Typical forest ecosystem models are BIOME-BGC (Hidy et al., 2016), BASFOR (Van Oijen et al., 2011) and PnET-N_DNDC ( $\mathrm{Li}$ et al., 2000), usually applied to estimate forest 
Exploring the possibilities of parsimonious nitrogen modelling in different ecosystems productivity (Chen and Xiao, 2019a; Miehle et al., 2006; Sever et al., 2017), emitted nitrogen gases (Lamers et al., 2007; Norman et al., 2008), evaluate forest management practices (Garcia-Prats et al., 2018) and climate change impact (Cameron et al., 2013; Fibbi et al., 2019). While common agricultural models are DAISY (Abrahamsen and Hansen, 2000), CANDY (Franko et al., 1995) and MONICA (Nendel et al., 2011), which are frequently used to evaluate agricultural management practices (Gutzler et al., 2015; Kollas et al., 2015), crop yield (Salo et al., 2016), environmental impact (Manevski et al., 2015; Salazar et al., 2017) and climate change impact (Asseng et al., 2015; Rasmussen et al., 2018; Smith et al., 2007).

The main and shared characteristic of these models is the inclusion of the microbial biomass dynamics through the carbon cycle in order to accurately calculate nitrogen mineralization. In order to obtain a precise representation of the organic matter turnover, and as a consequence, of the nitrogen mineralization, all of them consider vegetation growth and several types of organic matter. However, both forest and agricultural ecosystem models at plot scale present high parameter requirements (Härkönen et al., 2019; Jabloun et al., 2018), which leads to a cumbersome calibration and frequently, to high computational time due to their complex structure (W. Jin et al., 2016). For this reason, using these models is difficult when the interest is focused on larger areas.

Therefore, watershed models are simpler and do not explicitly simulate the carbon cycle, which is partially or completely replaced by a set of carbonrelated parameters. Two models stand out for being the most widely used at watershed scale, SWAT (Arnold et al., 1998) and INCA-N (Wade et al., 2002), and although both have a carbon cycle sub-model, both carbon and nitrogen sub-models are not coupled, being their modelling independent. Hence, when the interest remains on the nitrogen cycle, the number of parameters to be calibrated or estimated is lower. Consequently, these models are being 
Exploring the possibilities of parsimonious nitrogen modelling in different ecosystems

broadly used to develop watershed management plans to face problems related to climate change (Jin et al., 2012; Whitehead et al., 2015; Yang et al., 2017; Zhou et al., 2019), environmental impact (De Girolamo et al., 2019; He et al., 2019; L. Jin et al., 2016; Pathak et al., 2018) and agricultural management practices (Granlund et al., 2015; Haas et al., 2017; Wang et al., 2018). 



\section{La Hunde forest: a natural ecosystem}

\subsection{Introduction}

Precipitation and temperature are the main drivers of ecosystem structure and function, controlling forest stand structure, ecosystem distribution patterns and net primary production at a continental scale (Newman et al., 2006). However, at smaller geographic scales, nutrient availability becomes a limiting factor in many ecosystems (Lozano-García et al., 2016; Newman et al., 2006) and, consequently, ecosystem structure and function usually change along a topographical soil properties gradient (Tateno et al., 2017).

Soils in Mediterranean drylands, are often nutrient poor and, as water content is highly variable, nutrient availability is a frequent limiting factor 
Exploring the possibilities of parsimonious nitrogen modelling in different ecosystems

for their ecosystem development (Sardans and Rodà, 2004). In fact, as net primary production responds to water and nutrient addition (Lü et al., 2018; Sardans and Peñuelas, 2013), in semiarid ecosystems it is difficult to know if vegetation growth is controlled by water, nutrient availability or both (Botter et al., 2008). For this reason, models including nutrient cycling are useful tools which allow the analysis of the relationships and behaviour of these ecosystems (Landsberg, 2003), especially in these Mediterranean ecosystems, which stand out in climate change projections as areas where warmer and drier conditions are predicted, leading to more severe and recurrent droughts (Spinoni et al., 2018). Since most of the annual nutrient requirements are supplied from the decomposition of soil organic matter (Aponte et al., 2010) and plant competition increases in resource-limited environments (Calama et al., 2019), changes in forest ecosystem function are expected because of alterations in water, carbon and nitrogen cycles (Dong et al., 2019). Nevertheless, there is a need to develop and test simple nutrient models (Blanco et al., 2005; Zhang et al., 2013), because parameter requirements of forest ecosystems models, which commonly include nutrient cycles, are usually high (Härkönen et al., 2019), leading to a cumbersome calibration and frequently, to high computational time due to their complex structure (W. Jin et al., 2016)..

Nitrogen is one of these limiting nutrients in Mediterranean ecosystems, for both photosynthetic capacity and growth (Sardans et al., 2008; Uscola et al., 2017) and, consequently, a better knowledge of its storage and cycling is crucial. However, nitrogen availability is markedly linked to the microbial activity because mineral nitrogen is the result of the microbial decomposition of organic matter, making the carbon and nitrogen cycles inextricably intertwined (Gleeson et al., 2016; Lucas-Borja et al., 2019; Pastor and Post, 1986), which means that nitrogen models should also include the carbon cycle for a proper modelling. Additionally, soil water content and soil temperature are the main environmental factors influencing these 
biogeochemical cycles (Manzoni et al., 2004; Rodrigo et al., 1997), especially in water-limited ecosystems (Wang et al., 2017), where significant interactions between microorganisms and water availability exist (Porporato et al., 2015). The wetting and drying cycles are a clear example, a common characteristic in arid and semiarid climates. This process leads to a fast rewetting in the short term after precipitation stimulating microbial activity, which speeds up decomposition and, as a result, nutrient release (LadoMonserrat et al., 2014). Thus, daily resolution models with a combined analysis of the water, carbon and nitrogen cycles are necessary for the complete understanding of these terrestrial ecosystems (D'Odorico et al., 2004).

In that sense, a new carbon-nitrogen model and two existing models of different conceptualization, complexity and purpose, which include the water, carbon and nitrogen cycles, were calibrated using the experimental data recorded in a Quercus ilex (holm oak) experimental site under a semiarid climate. The first model is the physically-based model BIOME-BGCMuSo v5.0 (Hidy et al., 2016), which is the modified version of the well-known BIOME-BGC model (Thornton et al., 2002), widely used in natural ecosystems, with an accurate description of the water, carbon and nitrogen cycles and vegetation growth (Chen and Xiao, 2019b; Chiesi et al., 2007; Fontes et al., 2010). The second one is the LEACHM model (Hutson, 2003) which is a process-based model developed to simulate water and solute transport in unsaturated or partially saturated agricultural soils and broadly used in agriculture to simulate the nitrogen cycle (Asada et al., 2013; Jung et al., 2010; Wöhling et al., 2013). These two models have been chosen because both include the groundwater transpiration process, necessary in this case study, and particularly, because BIOME-BGCMuSo v5.0 is able to accurately represent tree responses to environmental conditions and LEACHM has an accurate description of soil water and biogeochemical processes. However, these models have high parameter requirements, and consequently it can be 
Exploring the possibilities of parsimonious nitrogen modelling in different ecosystems challenging to use them in most situations, mainly because the available information is usually limited. Therefore, the third one is a new parsimonious carbon and nitrogen sub-model which has been coupled to the existing conceptual eco-hydrological model TETIS (Pasquato et al., 2015; Ruiz-Pérez et al., 2016a) and named TETIS-CN.

Within this framework, this approach firstly aims to contribute to a better understanding and modelling of the nitrogen cycle in natural ecosystems, and due to its linkage to the carbon cycle, the modelling of the carbon cycle and their interactions within the soil-plant continuum in semiarid conditions. Secondly, it also aims to test the capability of TETIS-CN to satisfactorily reproduce them.

\subsection{A brief introduction to facultative phreatophytes}

Semiarid areas are characterized by their limited water availability, shallow soils (Eliades et al., 2018) and deep groundwater table (Fan et al., 2013). Trees in water-limited environments are exposed to long dry seasons and many species have developed several adaptation mechanisms (Lubczynski, 2009; Rodriguez-Iturbe et al., 2001). One of these mechanisms is the development of deep groundwater tapping roots. These species are termed facultative phreatophytes, characterized by the infrequent or partial use of groundwater resources to survive (Macfarlane et al., 2018), a process commonly known as "groundwater transpiration". Q. ilex is one of the main Mediterranean evergreen oaks in the Iberian Peninsula that grows in its semiarid areas. In these environments, $Q$. ilex has developed the morphological adaptive mechanism of deep tap roots (Barbeta and Peñuelas, 2016) and its rooting system can reach depths up to $3.7 \mathrm{~m}$ (Canadell et al., 1996). Therefore, $Q$. ilex is able to access the water table or extend its root system through fractured rock to access stored water (Schwinning, 2010). 
Exploring the possibilities of parsimonious nitrogen modelling in different ecosystems

Most of these $Q$. ilex forests grow in the upper part of catchments and their actual evapotranspiration can heavily influence downstream water availability (Vicente et al., 2018). Globally, mean annual evapotranspiration accounts for $67 \%$ of mean annual precipitation (Yongqiang Zhang et al., 2016), while this value can exceed 85\% (Morillas et al., 2013; Piñol et al., 1991; Yaseef et al., 2010) in water-limited environments, such as complex Mediterranean ecosystems with wide inter- and intra-annual precipitation variability (Gallart et al., 2002; García-Ruiz et al., 2011). Thus groundwater transpiration in these ecosystems cannot be neglected, and several studies have shown its key contribution to total plant transpiration (Barbeta and Peñuelas, 2017; David et al., 2004; Miller et al., 2010; Swaffer et al., 2014; Witty et al., 2003). Nevertheless, this groundwater transpiration is not often considered in conventional hydrological models and, consequently, the results frequently underestimate the actual evapotranspiration and overestimate the net recharge (Balugani et al., 2017; Eliades et al., 2018).

Hence, more attention needs to be paid to groundwater transpiration because it is a critical aspect, and one that should be included in the hydrological models used under semiarid conditions to obtain a more realistic water balance closure. For this reason, the three models used in this first approach were used considering groundwater transpiration. In this study plot, soil moisture, interception and transpiration measurements are available, and the impairment between soil moisture and transpiration during summer drought periods suggests that $Q$. ilex may have access to subsoil water resources, at least during these periods (del Campo et al., 2019a; Vicente et al., 2018).

As a result, this first approach also aims to better understand the hydrological behaviour of facultative phreatophytes, serve as a springboard to improve future hydrological models to make them more suitable to be 
Exploring the possibilities of parsimonious nitrogen modelling in different ecosystems applied in regions covered by such species and consequently improve future predictions.

\subsection{Study area}

The study area (Figure 3-1) is an experimental plot covering 1,800 $\mathrm{m}^{2}$ located in the forest Monte de la Hunde in east Spain (3904'29-30" N, 1'14'25-26" W elevation 1,080-1,100 $\mathrm{m}$ a.s.l.). Soil texture is loam with a high degree of stoniness, a basic $\mathrm{pH}$, high calcium carbonate content and a decreasing in depth content of soil organic carbon (Table 3-1). The slope is $31 \%$ with a NW aspect. Soil thickness ranges from $10 \mathrm{~cm}$ to $40 \mathrm{~cm}$, and underneath a karstified Jurassic limestone parent rock arises with faults and fissures, which were revealed by the boreholes (depth up to $4 \mathrm{~m}$ ) drilled all over the plot (del Campo et al., 2019b). The water table was not found within these 4 $\mathrm{m}$, but the parent rock is a significant reservoir of deep water (del Campo et al., 2019b) forming a perched aquifer, a common characteristic in Mediterranean catchments (Medici et al., 2008). The mean annual precipitation, air temperature and reference evapotranspiration (Hargreaves and Samani, 1985) are respectively $466 \mathrm{~mm}, 12.8^{\circ} \mathrm{C}$ and $1,200 \mathrm{~mm}$, according to the meteorological dataset (1960-2011) of a nearby weather station (AyoraLa Hunde, SAIH network). In line with the Köppen climate classification, it is a water-limited environment with a semiarid climate. The forest is a highdensity stand of Q. ilex where other species (Pinus halepensis, Q. faginea, Juniperus phoenicea and J. oxycedrus) are barely present. The forest structure was characterized in May 2012 and the results were: $10.7 \mathrm{~cm}$ and $7.7 \mathrm{~cm}$ of diameter at the basal and breast heights, respectively, $5.6 \mathrm{~m}^{2}$ ha-1 basal area and a density of 1,059/1,133 trees ha-1 (holm oak/all trees) (del Campo et al., 2019a). The Leaf Area Index (LAI) was seasonally measured (approximately 3 times a year) and its average value was $1.13 \pm 0.22 \mathrm{~m}^{2} \mathrm{~m}^{-2}$ (2012-2016). 
Exploring the possibilities of parsimonious nitrogen modelling in different ecosystems

Table 3-1 I Soil characteristics of the study site. SOC means soil organic carbon. Particle fractions (texture) in the following order: sand, silt and clay (\%). (Bautista et al., 2015; del Campo et al., 2018).

\begin{tabular}{cccccc}
\hline Layer & $\begin{array}{c}\text { Stoniness } \\
(\mathbf{\%})\end{array}$ & $\mathbf{p H}$ & $\mathrm{CaCO}_{3} \mathbf{( \% )}$ & $\begin{array}{c}\mathrm{SOC} \\
\left(\mathbf{g ~ k g}^{-1}\right)\end{array}$ & Texture \\
\hline L Layer & $48.4 \pm 10.7$ & - & - & - & - \\
$\mathbf{H}$ Layer & $59.2 \pm 7.1$ & $7.84 \pm 0.09$ & $15.3 \pm 5.6$ & $131.2 \pm 32.0$ & - \\
$\mathbf{0 - 1 0} \mathbf{~ c m}$ & $63.9 \pm 8.5$ & $8.05 \pm 0.11$ & $21.1 \pm 6.7$ & $73.2 \pm 17.4$ & $44 ; 33 ; 23$ \\
$\mathbf{1 0 - 3 0} \mathbf{~ c m}$ & $58.6 \pm 7.3$ & $8.25 \pm 0.12$ & $34.1 \pm 6.2$ & $42.3 \pm 21.4$ & $57 ; 23 ; 20$ \\
$\mathbf{3 0 - 4 0} \mathbf{~ c m}$ & $55.5 \pm 7.2$ & $8.34 \pm 0.04$ & $36.7 \pm 1.7$ & $25.1 \pm 6.4$ & $48 ; 32 ; 20$ \\
\hline
\end{tabular}

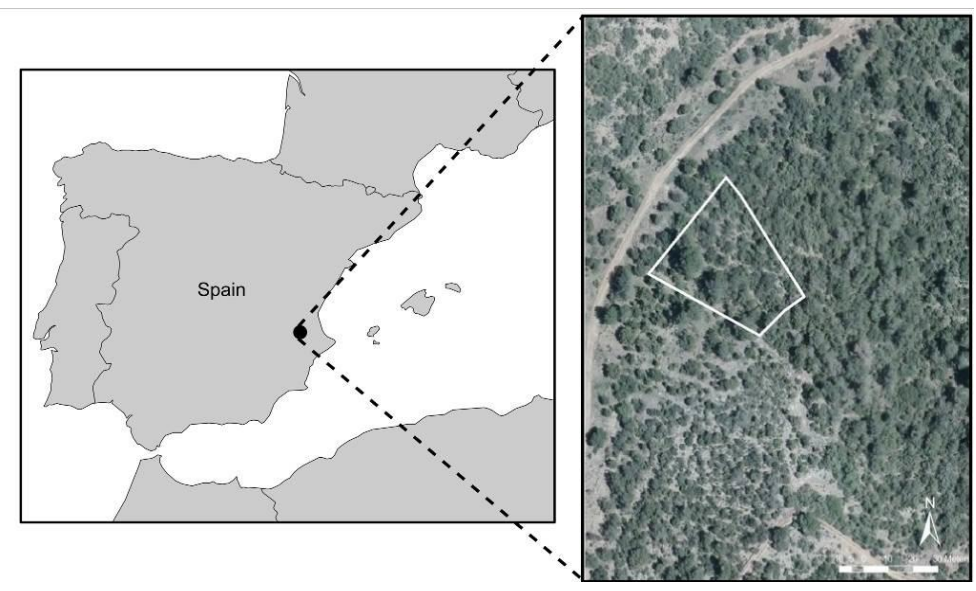

Figure 3-1 I Location of the experimental plot study site.

\subsection{Data}

The data used in this approach can be classified in two groups: meteorological data (forcing data) and measured hydrological variables, and data related to some carbon and nitrogen variables. In the following lines, a description about the collection of these data is given and Table 3-2 summarizes the type, temporal availability and temporal model use.

\subsubsection{Meteorological data and hydrological field measurements}

All the meteorological data and hydrological field measurements were recorded every 10 minutes, and averaged on a daily basis during the observational period from $01 / 10 / 2012$ to $26 / 04 / 2016$. A complete description 
Exploring the possibilities of parsimonious nitrogen modelling in different ecosystems of the methodology employed to obtain the meteorological variables and field measurements can be found in del Campo et al. (2019a, 2018).

Air temperature and relative humidity were recorded by a Decagon Device $\mathrm{T} / \mathrm{RH}$ sensor at a 2-metre height above the ground surface. Precipitation was continuously measured in an open area $20 \mathrm{~m}$ away from the plot using a Davis tipping bucket rain gauge with a resolution of $0.2 \mathrm{~mm}$. Throughfall was measured according to the methodology described in del Campo et al. (2018).

Table 3-2 I Type, temporal availability and temporal model use for each measurement.

\begin{tabular}{lccc}
\hline \multicolumn{1}{c}{ Data } & Type & Temporal availability & $\begin{array}{c}\text { Temporal } \\
\text { model use }\end{array}$ \\
\hline Air temperature & Input & Every ten minutes & Daily \\
Relative humidity & Input & Every ten minutes & Daily \\
Precipitation & Input & Continuously & Daily \\
Throughfall & Input & Every ten minutes & Accumulated \\
Runoff & State variable & Every ten minutes & Accumulated \\
Soil water content & State variable & Every ten minutes & Daily \\
Transpiration & State variable & Every thirty minutes & Weekly \\
LAI & Input & Weekly & Daily \\
Mineralization & State variable & Every two months & Accumulated \\
Nitrification & State variable & Every two months & Accumulated \\
Nitrogen leaching & State variable & Every two months & Accumulated \\
NH $^{+}$soil content & State variable & Every two months & Punctual \\
NO $_{3}{ }^{-}$soil content & State variable & Every two months & Punctual \\
Soil respiration & State variable & Every one or two months & Punctual \\
\hline
\end{tabular}

Soil water content measurements were taken with a Decagon Device EC-5. Fifteen probes were installed at depths of 5, 15, and $30 \mathrm{~cm}$ and the default calibration of the probes for the mineral soils was used. Runoff was measured in a collecting trench placed at the lower boundary of the slope by a Diehl Metering Altair v4 volumetric counter.

The heat ratio method (Burgess et al., 2001) was followed to measure sap flow velocity in 14 trees, which were divided into four different diametrical 
distributions. In each tree, an ICT International sap flow sensor was installed on the north trunk side. These measurements were upscaled to stand transpiration, and accounted for tree density and tree diameter frequency distribution.

It should be highlighted that in summer months, a positive difference between transpiration and soil water content changes was observed (i.e. transpiration $>$ soil water content changes) (Figure 3-2). This impairment between soil moisture and transpiration during summer drought periods is only possible if $Q$. ilex takes groundwater resources, hence the hypothesis of additional groundwater transpiration is justified.

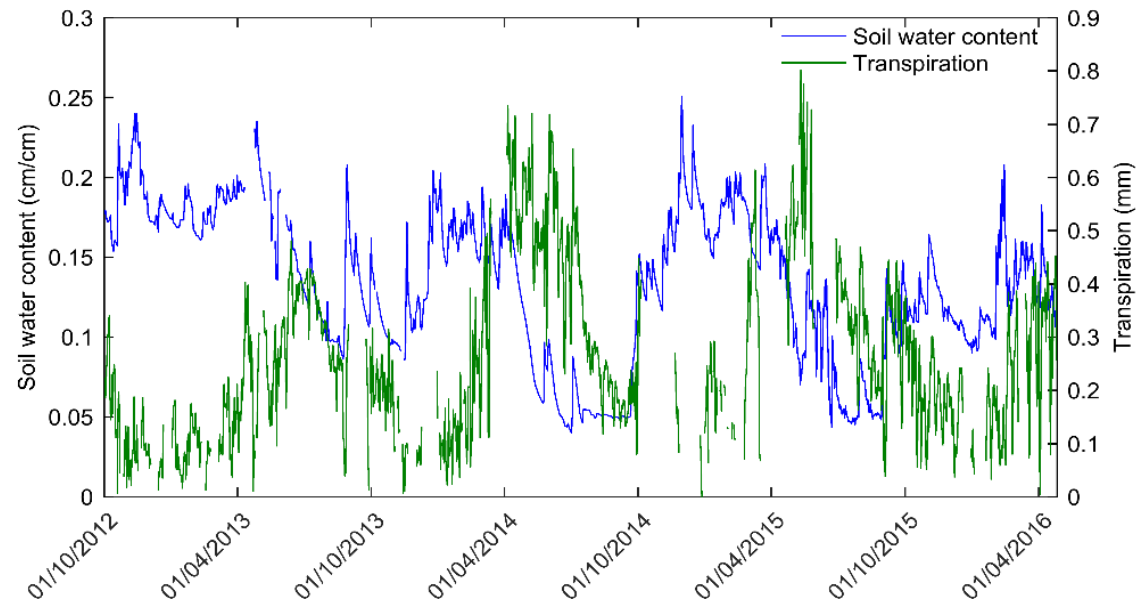

Figure 3-2 I Observed soil water content and transpiration series.

The LAI was seasonally measured in the field 12 times during the observational period by an LAI-2000 sensor. The series was completed with estimations made from the level-4 MODIS global LAI satellite product (NASA, LPDAAC). The MODIS LAI dataset was reprojected on the UTM projection system, and a linear regression was calculated between it and the LAI measured in the field to adjust the MODIS LAI dataset. The resultant LAI was linearly interpolated to obtain daily results. 
Exploring the possibilities of parsimonious nitrogen modelling in different ecosystems

\subsubsection{Soil carbon and nitrogen field measurements}

In the case of the carbon and nitrogen field measurements, the observational period only covers the first two hydrological years (01/10/2012 - 30/09/2014). Soil samples were collected from the first $15 \mathrm{~cm}$ of soil every two months approximately, and from 9 different sites homogenously distributed inside the plot in order to deal with the common heterogeneity in the spatial distribution of carbon and nitrogen, which is mainly caused by the patchy distribution of vegetation and its variability in life forms (Austin et al., 2004).

Mineralization, nitrification and nitrogen leaching were measured by the disturbed buried core method (DiStefano and Gholz, 1986), assuming that nitrogen transformation rates inside and outside the cores are similar. The core tubes are $15 \mathrm{~cm}$ long with a section of $4.75 \mathrm{~cm}$ and a resin bag on the bottom containing $5 \mathrm{~g}$ of mixed-bed resin beads of Dowex $1 \times 8 \mathrm{Cl}^{-} 100-200$ mesh and Dowex 50x8 $\mathrm{H}^{+}\left(\mathrm{K}^{+}\right)$50-100 mesh resins to absorb N-NH $4^{+}$and $\mathrm{N}$ $\mathrm{NO}_{3}{ }^{-}$, respectively. Soil samples were placed in the cores, where they were left incubating (in situ buried cores). Part of the same soil used to fill the cores was kept refrigerated and transported to the lab where the initial $\mathrm{N}-\mathrm{NH}_{4}{ }^{+}$ and $\mathrm{N}_{-} \mathrm{NO}_{3}{ }^{-}$soil contents were obtained by means of a flow injection analyser (FIAStar 5000, Foss Tecator, Höganäs, Sweden). The process was repeated approximately every two months, replacing the incubated soil by new soil, and taking it and a sample of the new soil to the lab, where initial (new soil) and final (incubated soil) $\mathrm{N}-\mathrm{NH}_{4}{ }^{+}$and $\mathrm{N}-\mathrm{NO}_{3}{ }^{-}$soil contents were obtained. From the mass balance between the initial and final soil contents, net mineralization and net nitrification accumulated during the incubation period were calculated. The $\mathrm{N}-\mathrm{NH}_{4}{ }^{+}$and $\mathrm{N}-\mathrm{NO}_{3}{ }^{-}$accumulated in the deeper resin bag corresponded to the $\mathrm{N}-\mathrm{NH}_{4}{ }^{+}$and $\mathrm{N}-\mathrm{NO}_{3}{ }^{-}$accumulated leaching, whilst the initial $\mathrm{N}-\mathrm{NH}_{4}{ }^{+}$and $\mathrm{N}_{-} \mathrm{NO}_{3}{ }^{-}$soil contents corresponded to the punctual $\mathrm{N}-\mathrm{NH}_{4}{ }^{+}$and $\mathrm{N}-\mathrm{NO}_{3}{ }^{-}$observations. 
An EGM-4 environmental gas monitor from PP System Company was used to obtain the $\mathrm{CO}_{2}$ efflux (total soil respiration). All the measurements were made at midday, between 1100 and 1300 CET and every one or two months on 9 PVC collars (10 cm in diameter and $5 \mathrm{~cm}$ depth) introduced $3 \mathrm{~cm}$ into the soil.

\subsection{Models description}

Three models of different complexity, conceptualization and purpose were used in this first approach: (1) the physically-based model BIOMEBGCMuSo v5.0, (2) the process-based model LEACHM and, (3) the parsimonious TETIS-CN model. In the following lines, BIOME-BGCMuSo and LEACHM are briefly described, while TETIS-CN is described in detail.

Table 3-3 shows a comparison between model characteristics.

\subsubsection{BIOME-BGCMuSo model}

The BIOME-BGCMuSo v.5.0 model (Hidy et al., 2016) is the modified version of BIOME-BGC model (Thornton et al., 2002), hereafter referred as BIOME, which has been widely used in natural ecosystems (Chen and Xiao, 2019b; Chiesi et al., 2007; Fontes et al., 2010). It is a biogeochemical model with a multilayer soil sub-model, which simulates the storage and flux of water, carbon and nitrogen between the ecosystem and the atmosphere, and within the components of the terrestrial ecosystem. It uses a scale of $1 \mathrm{~m}^{2}$, daily meteorological data, site-specific data, ecophysiological data, carbon-dioxide concentration $\left(\mathrm{CO}_{2}\right)$ and $\mathrm{N}$-deposition data to simulate the biogeochemical processes of the given biome. The soil profile is divided into 10 layers and the main simulated processes assessed are photosynthesis, allocation, litterfall, carbon, nitrogen and water dynamics in the plant, litter and soil. The model is composed by 60 plant functioning parameters, 24 senescence and soil parameters, 12 growing season parameters, 14 rate scalars, $7 \mathrm{CH} 4$ parameters and 7 phenological phases, with 11 parameters each (Table A-1). 
Table 3-3 I Model characteristics comparison.

\section{BIOME}

Hydrological parameters

Carbon and nitrogen parameters

Total number of parameters

Number of layers

Soil water movement

\section{Transpiration}

Dead plant material fractions

Soil organic matter fractions

Inorganic nitrogen fractions

Soil organic matter decomposition

Nitrogen transformations

Nitrogen sorption

Solute movement

$-$

$-$

194

10

Tipping bucket water

balance between layers

Based on the Penman-

Monteith equation using stomatal conductance

5

4

First-order kinetics

First-order kinetics

Fixed percentage

Advective movement
LEACHM

$15+9$ nlayers

$19+5$ nlayers

$34+14$ nlayers

$\mathrm{n}$ (8 herein)

Richards' equation

(Nimah and Hanks, 1973)

0 (included in soil

organic matter)

3

2

First-order kinetics

First-order kinetics

Linear isotherm

Convection-diffusion equation
TETIS-CN

21

19

40

2

Tipping bucket water balance (4 tanks)

Multiplicative function relating transpiration and the environmental variables

0 (included in soil organic matter)

3

2

First-order kinetics

First-order kinetics

Linear isotherm

Advective movement 
As stated by Hidy et al. (2016), the three most important blocks of the model are the phenological, the carbon flux, and the soil flux block. The phenological block calculates foliage development and therefore affects the accumulation of carbon and nitrogen in leaf, stem (if present), root and consequently the amount of litterfall. In the carbon flux block, gross primary production (GPP) of the biome is calculated using Farquhar's photosynthesis routine (Farquhar et al., 1980) and the enzyme kinetics model based on Woodrow and Berry (1988). Autotrophic respiration is separated into maintenance and growth respirations. In addition to temperature, maintenance respiration is calculated as the function of the nitrogen content of living plant pools, while growth respiration is a fixed proportion of the daily GPP. The soil block describes the decomposition of dead plant material and soil organic matter, nitrogen mineralization, and nitrogen balance (Running and Gower, 1991). Dead plant material is partitioned into coarse woody debris and litter, the latter represented by 4 different fractions. Soil organic matter is also divided into four fractions: fast, medium, slow and recalcitrant (humus). Two elements (carbon and nitrogen) represent each fraction and both elements in litter and soil organic matter are transferred into sequentially slower decomposing pools. Organic carbon decomposition is calculated by multiplying the decomposition rate by the carbon content in each pool (i.e., first-order kinetics). Heterotrophic respiration is calculated through the respiration fraction, which is different for each pool. All rates are adjusted based on temperature and soil water content. The soil hydrological calculation can be carried out by using Richards's equation or a "tipping bucket" water balance approach (used in this case study). The model differentiates between soil and groundwater transpiration.

\subsubsection{LEACHM model}

The second model employed in this study is the LEACHM model (Hutson, 2003). LEACHM has been broadly used for simulating water and solutes movement in unsaturated soils (Asada et al., 2015, 2013; Contreras et al., 
Exploring the possibilities of parsimonious nitrogen modelling in different ecosystems 2009; Lidón et al., 2013; Nasri et al., 2015). It is a one-dimensional model that divides the soil profile into a user's fixed number of horizontal layers of equal thickness. It employs finite differencing approximation techniques to simulate flow and redistribution of water and solutes; the model homogenously divides the time step and inputs at least into 10-time intervals per day. Its hydrological sub-model is composed of 24 parameters, nine of them defined for each soil layer, and its carbon-nitrogen sub-model is also composed of 24 parameters, five of them defined for each soil layer (Table A-2). Therefore, the model is composed of 48 parameters, but 14 of these parameters are defined for each soil layer, and consequently, increasing the number of layers considerably increases the number of parameters to be estimated or calibrated.

In order to describe the water flow in the unsaturated zone, LEACHM employs the Richards' equation, in which soil moisture and hydraulic conductivity are related by the equation proposed by Campbell (1974). The model offers the possibility of simulating a fixed depth water table as the lower boundary condition. The hydraulic head gradient is assumed to be zero between the phreatic surface and the bottom of the simulated profile and, hence, upward water flow is considered (capillary fringe). Thus, no modification in the code is needed to reproduce the facultative phreatophytes' behaviour. Runoff estimate is based on the equation proposed by Williams (1991), with the advantage of adjusting the runoff curve number according to the slope. Potential evapotranspiration is split into potential evaporation and potential transpiration according to the plant cover fraction. Actual evaporation is calculated in accordance with the potential evaporation and the maximum possible evaporative flux density while actual transpiration is calculated following Nimah and Hanks (1973) as a function of the soil's unsaturated hydraulic properties and the effective water potential gradient at roots-soil interface. The potential transpiration 
may be increased by the difference between potential and actual evaporation.

Soil organic matter is divided in LEACHM into three different fractions: plant residue (litter), manure (easily degradable) and humus (relatively stable), each one with its corresponding two pools (carbon and nitrogen). Biomass remains an integral part of the plant residue pool. Soil organic matter decomposition is described by first-order kinetics in the carbon pools and nitrogen transformations are given by the $\mathrm{C} / \mathrm{N}$ ratio of the decomposition products, that in turn, controls net mineralization, that is, the mineral nitrogen released or consumed by the microbial biomass. The synthesis efficiency factor defines the relative production of $\mathrm{CO}_{2}$ (heterotrophic respiration) and humus, while the humification factor determines the split between humus and biomass. Nitrification, volatilization, and denitrification processes are also modelled by first-order kinetics. Ammonium adsorption and desorption by clay colloids is modelled by a linear sorption isotherm. All transformation equations are corrected accounting for the influence of soil water content and soil temperature $\left(\mathrm{Q}_{10}\right.$ type function), however, it should be highlighted that an error was found in the code, by which, the temperature correction function was not changing the daily temperature in the case of using the Richards' equation. This error was corrected. Solute transport is modelled following the convectiondiffusion equation. Finally, plant nitrogen uptake occurs in the transpiration flux, but if this does not satisfy the requirements (daily potential uptake), a diffusive component for nitrate is considered. In the case of perennial vegetation, a constant daily potential uptake is calculated from the yearly value.

Additionally, in this case study, as LEACHM does not simulate plant growth, two new parameters were added to the model with the aim of characterizing the plant residue input: a plant death constant $\left(\mathrm{gC} \mathrm{m}^{-2} \mathrm{day}^{-1}\right)$, 
Exploring the possibilities of parsimonious nitrogen modelling in different ecosystems

which accounts for litterfall and root mortality, and the $\mathrm{C} / \mathrm{N}$ ratio of the plant residue. Since the rate of added organic matter changes over time, a fixed annual curve based on the measured litterfall curve was considered.

\subsubsection{TETIS-CN model}

The TETIS-CN model divides the soil profile into two layers, allows fixing an evaporation depth in this shallow first layer and hence, the evapotranspiration split between bare soil evaporation and transpiration in this first layer, which is necessary in order to properly reproduce nutrient cycles. On the one hand, the hydrological sub-model (Pasquato et al., 2015; Ruiz-Pérez et al., 2016a) is based on a tank type conceptualization in which water moves downwardly as long as the tank outflow capacity is not exceeded (Figure 3-3). However, the calculation of transpiration has been improved, mainly to incorporate the groundwater transpiration process. After these improvements, the sub-model at plot scale is composed of 21 parameters (Table A-3). On the other hand, the new carbon and nitrogen submodel (Figure 3-4) is based on the model proposed by Porporato et al. (2003) because it is already a parsimonious model. It divides soil organic matter into three fractions, which is in good agreement with Batlle-Aguilar et al. (2011) and Jenkinson et al. (1990), who proposed that models should divide soil organic matter at least between two and four fractions to obtain reliable results, while more complex models commonly comprise five (Lardy et al., 2011) or even more, as BIOME. However, this model has been improved. Volatilization, denitrification, $\mathrm{NH}_{4}{ }^{+}$sorption and a temperature correction function have been included, and additionally, the soil water correction functions have been improved. This final carbon-nitrogen sub-model is composed of 19 parameters (Table A-3), leading to a total of 40 parameters. Additionally, the model offers the possibility of activating a dynamic vegetation sub-model. However, for simplicity and in order to explore the basic mechanisms of the carbon and nitrogen cycles, the LAI values 
Exploring the possibilities of parsimonious nitrogen modelling in different ecosystems simulated by the dynamic vegetation sub-model were introduced as inputs, keeping the vegetation sub-model deactivated.

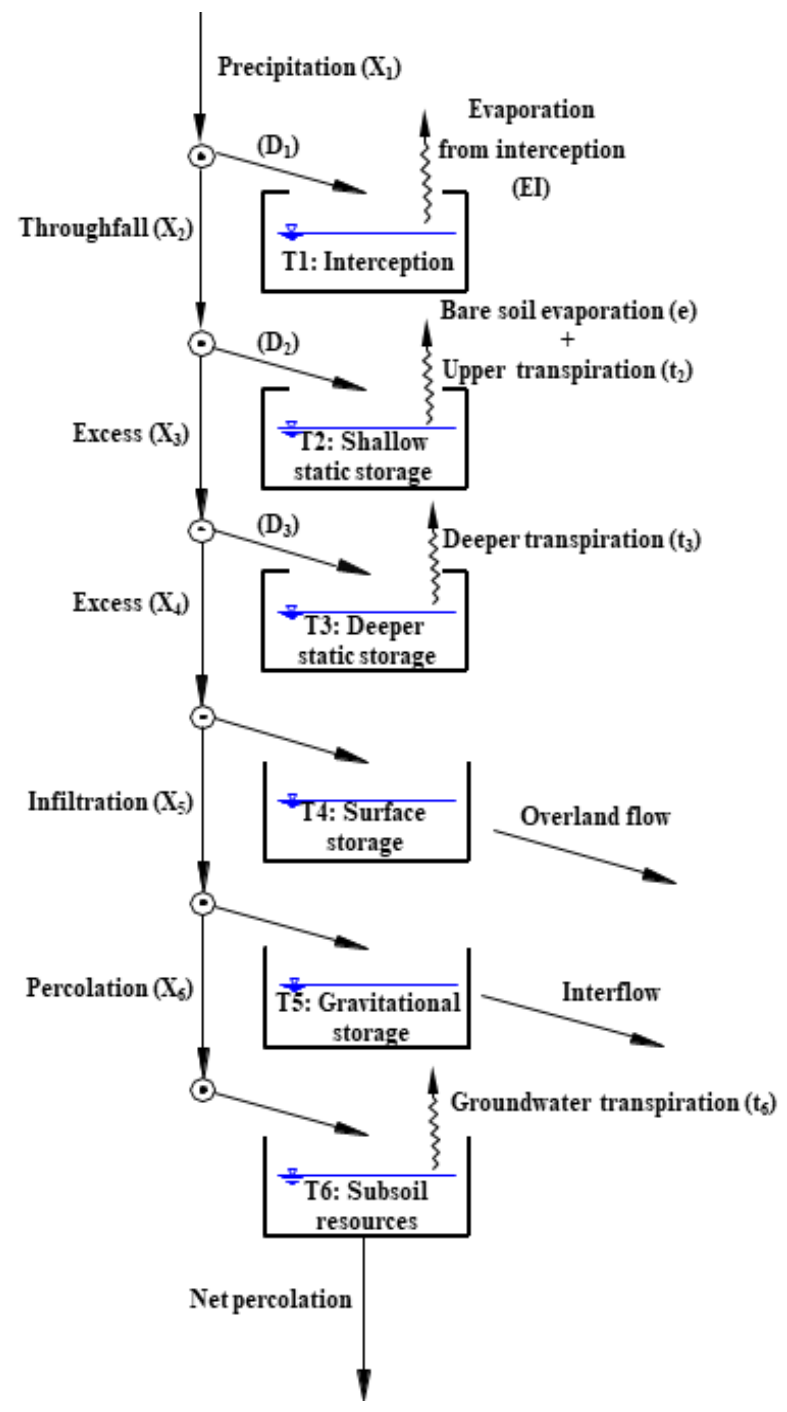

Figure 3-3 I Schema of the adapted hydrological sub-model of TETIS-CN.

The first tank $\left(\mathrm{T}_{1}\right)$ represents the intercepted water, which can only exit by direct evaporation:

$$
D_{1}(t)=\min \left[X_{1}(t) ; l_{s} \operatorname{LAI}(t) f_{c}-T_{1}(t-1)\right]
$$


Exploring the possibilities of parsimonious nitrogen modelling in different ecosystems

where $t$ is time, $D_{1}$ is the intercepted water $(\mathrm{mm}), X_{1}$ is precipitation $(\mathrm{mm}), l_{\mathrm{s}}$ is maximum leaf storage $(\mathrm{mm}), L A I$ is Leaf Area Index $\left(\mathrm{m}^{2} \mathrm{~m}^{-2}\right), f_{c}$ is vegetation cover factor and $T_{1}$ is the interception tank storage $(\mathrm{mm})$. Tanks $\mathrm{T}_{2}$ and $\mathrm{T}_{3}$ represent the static storage of soil. Water flows to these tanks according to:

$$
D_{i}(t)=\min \left[X_{i}(t)\left(1-\frac{T_{i}(t-1)}{H u_{i}}\right)^{\exp _{i}} ; H u_{i}-T_{i}(t-1)\right]
$$

where $i$ refers to either the shallow soil layer (2) or the deeper soil layer (3), $D_{i}$ is the water retained in soil by capillary action $(\mathrm{mm}), X_{i}$ is throughfall or excess $(\mathrm{mm}), T_{i}$ is the shallow or deeper static storage $(\mathrm{mm}), H u_{i}$ is the maximum static storage water content of each layer $(\mathrm{mm})$ and $\exp _{i}$ is a constant. This exponent takes values between 0 and 3. A value that differs from 0 means that there is excess before the static storage tank reaches its maximum capacity. Vertical flows are calculated as a balance in nodes. Hence, any water not retained moves downwardly whenever the outflow capacity is not exceeded (surface infiltration capacity or percolation capacity). The excess supplies tanks $T_{4}$ and $T_{5}$, which act as linear storages characterized by residence times.

Evaporation from interception is calculated as:

$$
E I(t)=\min \left[E T_{0}(t) f_{E T} ; T_{1}(t)\right]
$$

where $E I$ is evaporation from the interception $(\mathrm{mm}), E T_{0}$ is the potential evapotranspiration $(\mathrm{mm})$ and $f_{E T}$ is a correction factor for the total evapotranspiration. Therefore, transpiration is calculated using the remaining $\mathrm{ET}_{0}$. This point is where the previous version of the model has been improved. Firstly, the previous transpiration equation expressed the dependence of transpiration on the LAI as $\min (1, L A I(t))$. This term indicates that transpiration is not reduced if the LAI is above 1. However, some studies have found that this LAI value is around 6 and varies depending on climate and vegetation (Granier et al., 2000; Li et al., 2019). 
Nevertheless, instead of fixing this value at 6, it was added as a parameter to be calibrated. It was called $\mathrm{LAI}_{0}$ and represents the $\mathrm{LAI}$ value above which transpiration is not limited because of the LAI. Secondly, the possibility of transpiration from an intermediate tank $\left(\mathrm{T}_{6}\right)$ between the soil and the aquifer was added for this case study. Consequently, two new parameters were included: a soil moisture threshold $\vartheta_{G T}\left(\mathrm{~cm} \mathrm{~cm}^{-1}\right)$ and a groundwater root percentage $Z_{g}$. The former represents the profile soil moisture value below which the groundwater resources transpiration is triggered. The groundwater root percentage represents the percentage of roots located in the second soil layer that grows through the fractured rock to access these subsoil water resources. The new equations used to calculate transpiration are:

$$
t_{2}(t)=\min \left[\left(E T_{0}(t) f_{E T}-E I(t)\right) \frac{\min \left(L A I(t), L A I_{0}\right)}{L A I_{0}} \xi(t) Z_{1} f_{C} ; T_{2}(t)\right]
$$

$$
\begin{aligned}
& t_{3}(t) \\
& =\min \left[\left(\begin{array}{cc}
\left(E T_{0}(t) f_{E T}-E I(t)\right) \frac{\min \left(L A I(t), L A I_{0}\right)}{L A I_{0}} \xi(t)\left(Z_{2}+Z_{g t}\right) f_{c} & \vartheta(t) \geq \vartheta_{G T} \\
\left(E T_{0}(t) f_{E T}-E I(t)\right) \frac{\min \left(L A I(t), L A I_{0}\right)}{L A I_{0}} \xi(t) Z_{2} f_{c} & \vartheta(t)<\vartheta_{G T}
\end{array}\right) ; T_{3}(t)\right] \\
& t_{6}(t)=\min \left[\left(\begin{array}{cc}
0 & \vartheta(t) \geq \vartheta_{G T} \\
\left(E T_{0}(t) f_{E T}-E I(t)\right) \frac{\min \left(L A I(t), L A I_{0}\right)}{L A I_{0}} Z_{g t} f_{c} & \vartheta(t)<\vartheta_{G T}
\end{array}\right) ; T_{6}(t)\right]
\end{aligned}
$$

where $t_{i}$ is transpiration from soil layer $\mathrm{i}(\mathrm{mm}), \xi$ is a water stress factor, $f_{c}$ is the vegetation cover factor and $Z_{i}$ is the percentage of roots in layer $i$. The sum of $Z_{1}, Z_{2}$ and $Z_{g t}$ should equal one. Soil evaporation is calculated as:

$$
e(t)=\min \left[\left(E T_{0}(t)-E I(t)\right) \xi(t)\left(1-f_{c}\right) ; T_{2}(t)\right]
$$

where $e$ is soil evaporation and $\xi$ is a water stress factor or a soil water limitation for bare soil.

Soil organic matter is divided into three fractions: litter, humus and biomass; each one represented by two pools (carbon and nitrogen). The mass balance 
Exploring the possibilities of parsimonious nitrogen modelling in different ecosystems

between these pools is calculated in carbon terms and it is transformed to nitrogen by the $\mathrm{C} / \mathrm{N}$ ratio of each fraction. Microbial death, which is recirculated to the litter pool, is represented by a simple first-order kinetic, without considering soil water content or temperature influence:

$$
M D=k_{m d} C_{b}
$$

where $M D$ is microbial death $\left(\mathrm{gC} \mathrm{m}^{-3}\right.$ day $\left.^{-1}\right), k_{m d}$ is microbial biomass death rate $\left(\right.$ day $\left.^{-1}\right)$ and $C_{b}$ is biomass soil carbon content $\left(\mathrm{gC} \mathrm{m}^{-3}\right)$. However, as soil organic matter decomposition not only relies on the amount of decomposable material but also on the microbial activity, soil organic matter decomposition is described by a multiplicative expression:

$$
D E C_{i}=\varphi f(\vartheta) f(t) k_{i} C_{b} C_{i}
$$

which is still a first-order kinetics, but it includes the influence of the amount of organic matter and the decomposers (Manzoni and Porporato, 2007). The term $\varphi$ is a dimensionless factor which has a value of 1 , unless the litter is poor in nitrogen and immobilization is not enough for the microorganisms, $f(\vartheta)$ and $f(t)$ are terms accounting for the influence of soil water content and soil temperature respectively, $k_{i}$ is the decomposition rate of the litter or hummus soil carbon content $\left(\mathrm{m}^{3}\right.$ day $\left.^{-1} \mathrm{gC}^{-1}\right)$ and $C_{i}$ is litter or hummus soil carbon content $\left(\mathrm{gC} \mathrm{m}^{-3}\right)$. Nitrogen net mineralization is controlled by the $\mathrm{C} / \mathrm{N}$ ratio of the biomass, which should remain constant. The respiration rate defines the relative production of $\mathrm{CO}_{2}$ (heterotrophic respiration) while the humification factor determines the split between humus and biomass. Nitrification is calculated similarly to decomposition:

$$
N I T=\varphi f(\vartheta) f(t) k_{n i t} C_{b} N H_{4}^{+}
$$

where NIT is nitrification $\left(\mathrm{gN} \mathrm{m}^{-3} \mathrm{day}^{-1}\right), k_{n i t}$ is the nitrification rate $\left(\mathrm{m}^{3}\right.$ day $^{-1}$ $\left.\mathrm{gN}^{-1}\right)$ and $\mathrm{NH}_{4}{ }^{+} d$ is the dissolved fraction of $\mathrm{N}-\mathrm{NH}_{4}{ }^{+}$soil content $\left(\mathrm{gN} \mathrm{m}^{-3}\right)$. 


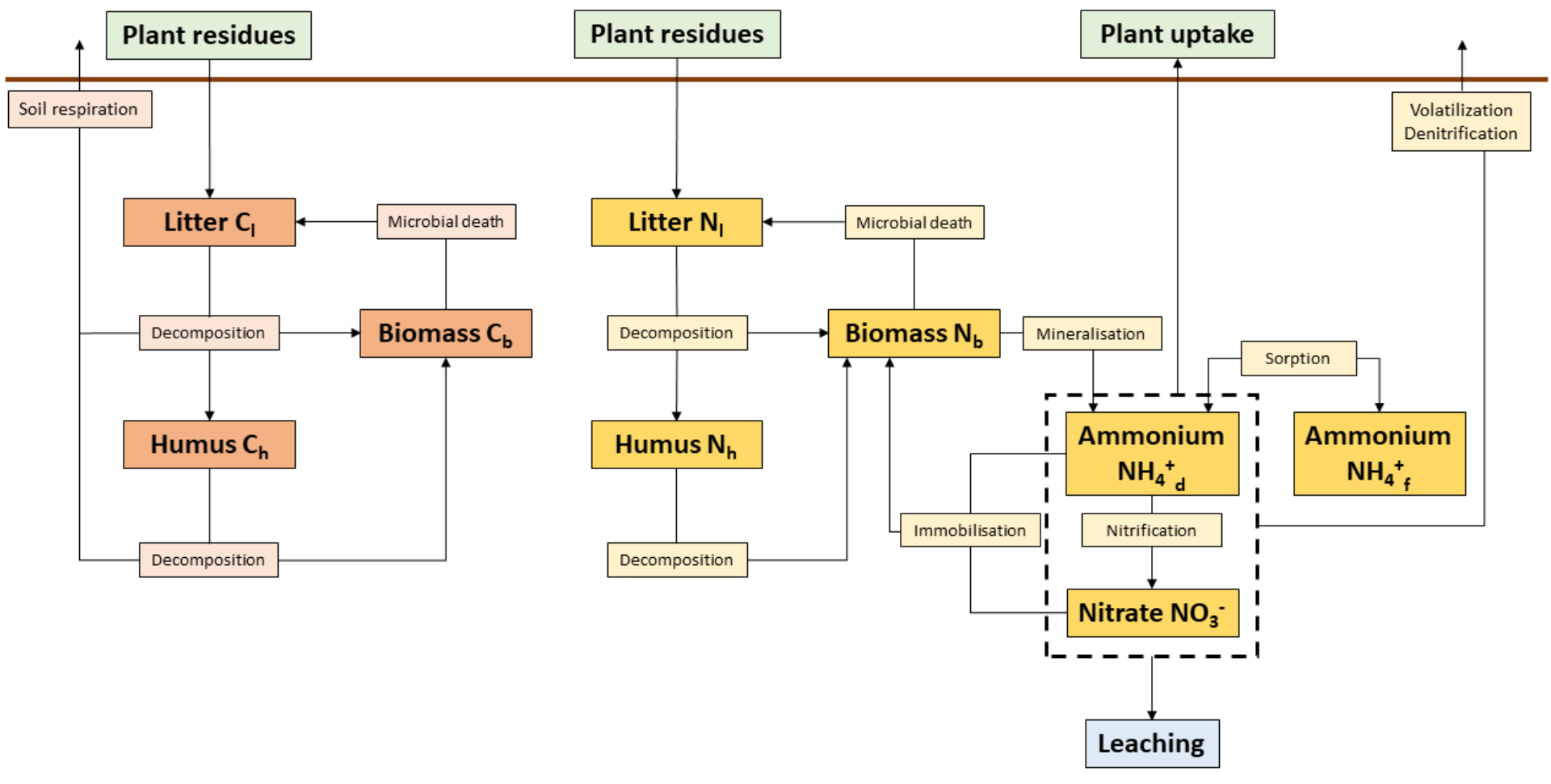

Figure 3-4 I Schema of the carbon and nitrogen sub-model of TETIS-CN. 
Exploring the possibilities of parsimonious nitrogen modelling in different ecosystems Volatilization and denitrification processes are less important at the daily-toseasonal time scale in natural soils (Porporato et al., 2003), hence, simple first-order kinetics are used. Volatilization is calculated as:

$$
V o l=f(\vartheta) f(t) k_{v o l} N H_{4}^{+}
$$

where $\mathrm{Vol}$ is volatilization $\left(\mathrm{gN} \mathrm{m}^{-3} \mathrm{day}^{-1}\right)$ and $k_{v o l}$ is volatilization rate $\left(\mathrm{day}^{-1}\right)$. Denitrification is calculated as:

$$
D e=f(\vartheta) k_{d e} N O_{3}^{-}
$$

where $D e$ is denitrification $\left(\mathrm{gN} \mathrm{m}^{-3} \mathrm{day}^{-1}\right), k_{d e}$ is denitrification rate $\left(\right.$ day $\left.^{-1}\right)$ and

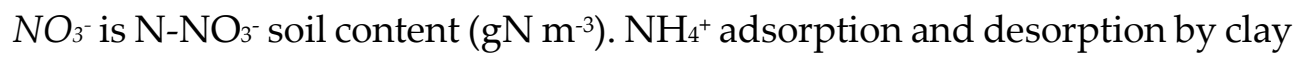
colloids is modelled in the simplest way, by a linear sorption isotherm:

$$
c_{S}=k_{d} c_{L}
$$

where $k_{d}$ is $\mathrm{NH}_{4}{ }^{+}$distribution coefficient $\left(\mathrm{dm}^{3} \mathrm{~kg}^{-1}\right), c_{s}$ is N-NH $4^{+}$concentration in the sorbed phase $\left(\mathrm{mgN} \mathrm{kg}^{-1}\right)$ and $c_{L}$ is $\mathrm{N}^{-\mathrm{NH}_{4}}{ }^{+}$concentration in solution $\left(\mathrm{mgN} \mathrm{dm}^{-3}\right)$.

Nitrogen uptake by vegetation is considered to occur proportionally to the transpiration flux, and if the nitrogen potential uptake is not accomplished, a diffusive flux is triggered, which is proportional to the nitrogen content and a diffusion coefficient. A constant daily potential uptake calculated from the yearly value is considered and $\mathrm{N}_{-} \mathrm{NH}_{4}{ }^{+}$and $\mathrm{N}^{-\mathrm{NO}_{3}}{ }^{-}$fluxes are considered to occur proportionally to the corresponding water flux (i.e., advective movement). In the case of $\mathrm{N}-\mathrm{NH}_{4}{ }^{+}$, only the dissolved fraction is considered to be available for nitrification, volatilization, plant nitrogen uptake and leaching.

The function controlling the influence of soil water content on decomposition, mineralization and nitrification processes is:

$$
f(\vartheta)= \begin{cases}\vartheta / \vartheta_{T} & \vartheta<\vartheta_{T} \\ \vartheta_{T} / \vartheta & \vartheta \geq \vartheta_{T}\end{cases}
$$


where $\vartheta_{T}$ is a soil moisture threshold $\left(\mathrm{cm} \mathrm{cm}^{-1}\right)$. Instead of field capacity, a threshold is used in order to reproduce the pulse dynamics observed in semiarid environments (Medici et al., 2012). This threshold is included as a parameter in the model. The function controlling the influence of soil water content on volatilization is:

$$
f(\vartheta)=\left\{\begin{array}{cc}
\vartheta / \vartheta_{T} & \vartheta<\vartheta_{T} \\
1 & \vartheta \geq \vartheta_{T}
\end{array}\right.
$$

and the soil water content correction function for denitrification is:

$$
f(\vartheta)= \begin{cases}0 & \vartheta<\vartheta_{T} \\ 1 & \vartheta \geq \vartheta_{T}\end{cases}
$$

The function controlling the influence of temperature is the one proposed by Kätterer and Andrén (2001).

Finally, as with LEACHM, in order to characterize the plant residue input, a plant death constant $\left(\mathrm{gC} \mathrm{m}^{-2}\right.$ day $\left.^{-1}\right)$ and its $\mathrm{C} / \mathrm{N}$ ratio were added as parameters and a fixed annual curve, based on the measured litterfall curve, was also considered.

\subsection{Methodology for model implementation}

Hydrological and biogeochemical models represent the reality in a simplified form and hence, their parameters are representative of the modelling scale, but differ from those measured in the field (Mertens et al., 2005). These parameters are usually known as effective parameters and the main purpose of a calibration process is to obtain them, which is a priority to make precise predictions. The objective of these effective parameters is to compensate for the error in the model structure, the spatial and temporal scale effects, and the error in the measured inputs and output variables (Abbaspour et al., 2007; Francés et al., 2007). Consequently, the three models were calibrated and validated. 


\subsubsection{Model evaluation}

The simulation period included the period with available observations. In the case of the water cycle, from 01/10/2012 to 26/04/2016 and a previous warming-up period (01/08/2012 to 30/09/2012) during which only meteorological data were available. The objective of the warming-up period was to eliminate the effect of the initial condition. The first two hydrological years were selected to calibrate the models and the remaining period to validate them. In the case of the carbon and nitrogen cycles, the period with available observations was shorter, from 01/10/2012 to 30/09/2014. The first year was used to calibrate the models, and the second one was used as validation; therefore, as model performance in terms of biogeochemistry was measured during two hydrologically calibrated years, the errors in reproducing the hydrology were not transferred to the biogeochemical performance of the models.

The hydrology was simulated for all the soil profile, however, since nitrogen measurements are representative of the first $15 \mathrm{~cm}$ of soil, the biogeochemistry was simulated only in these $15 \mathrm{~cm}$ of soil in this case study. BIOME and TETIS-CN were directly used with a daily time-step, while LEACHM was used with a 0.05-day time-step, although the output data are expressed daily. The three models were implemented by using the field measurements of soil water content, transpiration, ${\mathrm{N}-\mathrm{NH}_{4}+}^{+}$soil content, $\mathrm{N}$ $\mathrm{NO}_{3}{ }^{-}$soil content, accumulated net mineralization and accumulated net nitrification. Additionally, interception was used in the calibration process in the case of BIOME and TETIS-CN, and the measurements of mineral nitrogen leaching and soil respiration were only used to validate the models.

The soil water content data were daily averaged, but transpiration was averaged on a weekly basis because LEACHM employs weekly reference evapotranspiration and, although daily results are calculated, it is expected to simply match the weekly transpiration value. The interception data were 
used in the calibration of BIOME and TETIS-CN. LEACHM does not consider the process of interception, and throughfall (net precipitation) is the required input. Therefore, as the interception process in TETIS-CN is represented in a very simplified form, the interception data were used accumulated for the whole calibration period to improve the hydrological annual balance representation and to reduce the error, for both BIOME and TETIS-CN. Moreover, LEACHM and TETIS-CN do not calculate autotrophic respiration, therefore, in order to compare the results, the total soil respiration measurements were divided into autotrophic and heterotrophic respiration. According to Hanson et al. (2000), heterotrophic respiration in forests averages $51.4 \%$ of total soil respiration (sample of 37 forests), therefore, this value was used. Although soil respiration measurements correspond to the whole soil profile, as microbial biomass content is substantially higher in the surface soil layers (Fierer et al., 2003; Taylor et al., 2002), the calculated heterotrophic respiration can be compared with the results of the models, which correspond to the first $15 \mathrm{~cm}$ of soil. However, as it is a transformed variable, it was not used in the calibration process.

The goodness-of-fit index selected to measure the performance of the models was the Nash and Sutcliffe efficiency index (NS) (Nash and Sutcliffe, 1970), in the case of soil water content (NS_SWC) and transpiration (NS_TR), while the balance error (BE) was used in the case of interception, as it is used accumulated. Due to the lack of a long data series, the Root Mean Squared Error (RMSE) was used to measure the performance of the models in terms

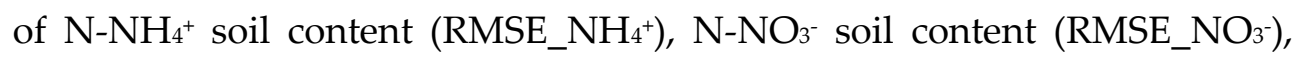
accumulated net mineralization (RMSE_Min), accumulated net nitrification (RMSE_Nit), accumulated mineral nitrogen leaching (RMSE_Leach) and heterotrophic soil respiration (RMSE_Resp). 


\subsubsection{Model calibration}

Calibration of BIOME was carried out using a two-stage procedure in which the default parameters were used as initial parameters values. First, automated model parameter estimation was conducted using PEST (modelindependent parameter estimation program) (Doherty, 2007). PEST has implemented a variant of the Gauss-Marquardt-Levenberg method of nonlinear parameter estimation and minimizes the weighted sum of squared residuals between observed and predicted values of the selected variables. In a second stage, the forward problem with ad hoc adjustment of parameters was repeatedly solved until the selected goodness-of-fit indices (NS and RMSE) of each of the calibrated state variables were considered acceptable.

LEACHM and TETIS-CN were calibrated in two different phases. As these models do not explicitly consider vegetation growth, vegetation transpiration is not influenced by nitrogen uptake, and consequently, the inclusion of the carbon and nitrogen cycles to the simulation does not affect the hydrological cycle. Hence, the first phase was the hydrological calibration and thereafter, the carbon and nitrogen sub-models were calibrated. However, generally, a single criterion in a calibration process does not suffice to measure all system's characteristics (Guo et al., 2013; Yapo et al., 1998) and a single-variable and single-objective calibration may lead to a parameter set not being considered acceptable (Vrugt et al., 2003) because the potential for obtaining equally acceptable fits to observational data with different parameter sets increases. This problem, introduced by Beven (1993), is called equifinality, and these non-acceptable parameter sets are called non-behavioural. Hence, in order to reduce them by constraining the model, initially, a manual calibration was performed, but then, an automatic calibration was carried out using the Multiobjective Shuffled Complex Evolution Metropolis (MOSCEM) algorithm (Vrugt et al., 2003), based on the concept of Pareto-optimal solutions. The interaction among the objective 
Exploring the possibilities of parsimonious nitrogen modelling in different ecosystems

functions during the calibration process leads to a set of solutions, called Pareto front, which represents the trade-offs among the different objectives with the property of improving the representation of one objective, while deteriorating the other one (Medici et al., 2012; Ruiz-Pérez et al., 2016b; Vrugt et al., 2003).

In the case of LEACHM, the model is able to represent the capillary fringe because it can consider a fixed water table. However, although soil depth is $30 \mathrm{~cm}$ in this case study, Q. ilex roots are deeper because this specie is able to extend its root system through fractured rock. Hence, extra layers had to be added as a method to reproduce transpiration from fractured rock (groundwater transpiration). Consequently, six layers $(5 \mathrm{~cm}$ thick) represented soil $(30 \mathrm{~cm})$ and 16 extra layers of the same thickness were added to represent the $Q$. ilex groundwater resources transpiration. This number of extra segments was determined in an initial manual calibration because, as each layer has different parameters, it can lead to a cumbersome programming procedure. Some of the required parameters were already measured in the field and were not included in the calibration process. The initial values of the non-measured parameters were those found in the literature (Jung et al., 2010; Lidón et al., 1999; Ramos and Carbonell, 1991; Schmied et al., 2000; Wöhling et al., 2013), calculated from the soil texture data, field observations and previous experience. Due to the observed data are scarce, the soil physical properties of the first six layers representing soil were grouped as pairs, and homogenous physical properties were considered in the 16 extra segments. From the $7^{\text {th }}$ layer, the percentage of roots was proportionally lowered in depth, and only the percentage of roots from the $1^{\text {st }}$ to the $7^{\text {th }}$ soil layer were calibrated. Moreover, the same mineralization, nitrification and denitrification rates were used for all soil layers (15 cm, first three layers). Soil water content and water flows were calculated until the $6^{\text {th }}$ soil layer because these layers are those that represent soil, while groundwater transpiration was calculated from the 16 extra 
Exploring the possibilities of parsimonious nitrogen modelling in different ecosystems

layers, which represented fractured rock. Biogeochemistry results were calculated only until the $3^{\text {rd }}$ soil layer $(15 \mathrm{~cm})$.

With TETIS-CN, as in this case study interflow was not observed throughout the monitoring period, the percolation capacity and residence time in the gravitational storage took a value of infinite, which meant that all the water was percolated. The initial manual calibration was carried out using the values recommended in the literature (Caylor et al., 2005; D'Odorico et al., 2003; GIMHA, 2018; Manzoni et al., 2004; Manzoni and Porporato, 2007; Porporato et al., 2001) and by taking field observations and previous experience into account.

For the hydrological calibration of both models the population size was set to 50.000 and the number of complexes came to 200. The compromise solution from the Pareto front was chosen according to the criteria: minimum Euclidean distance calculated using NS_SWC and NS_TR and, a BE less than $40 \%$ only in the case of TETIS-CN. For the biogeochemistry calibration, a population size of 50.000 and 200 complexes was used in the case of LEACHM, and as TETIS-CN is not as time-demanding, the population size was set to 100.000 and the number of complexes to 250 . The solution with a smaller value of Euclidean distance, calculated using the RMSE_NH4 ${ }_{4}^{+}$, RMSE_NO ${ }_{3}^{-}$, RMSE_Min and RMSE_Nit, was chosen from the Pareto front as a compromise solution.

The Euclidean distance is a mathematical criterion that represents the distance between a point of the Pareto Front and the ideal point (Guo et al., 2014; Herman et al., 2018), while the ideal point is the point of the Pareto Front that simultaneously minimizes both criteria. 


\subsection{Results}

The three models reproduced the general water dynamics of $Q$. ilex with acceptable accuracy after the calibration process, although better results were obtained during the calibration process and some differences between models were found in the case of the annual hydrological balance.

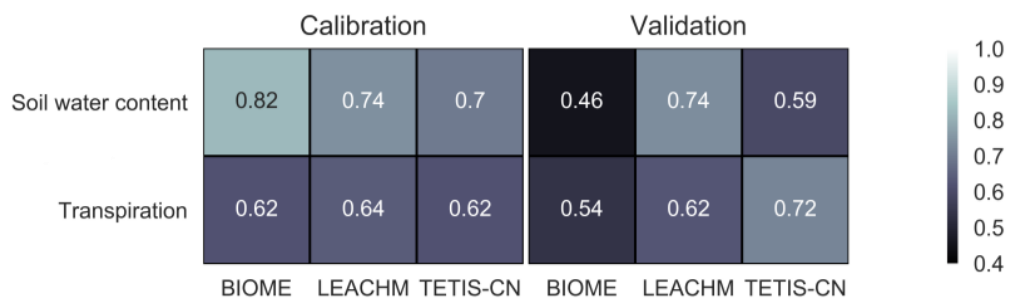

Figure 3-5 I Heatmap representation of soil water content and weekly transpiration NS indices.

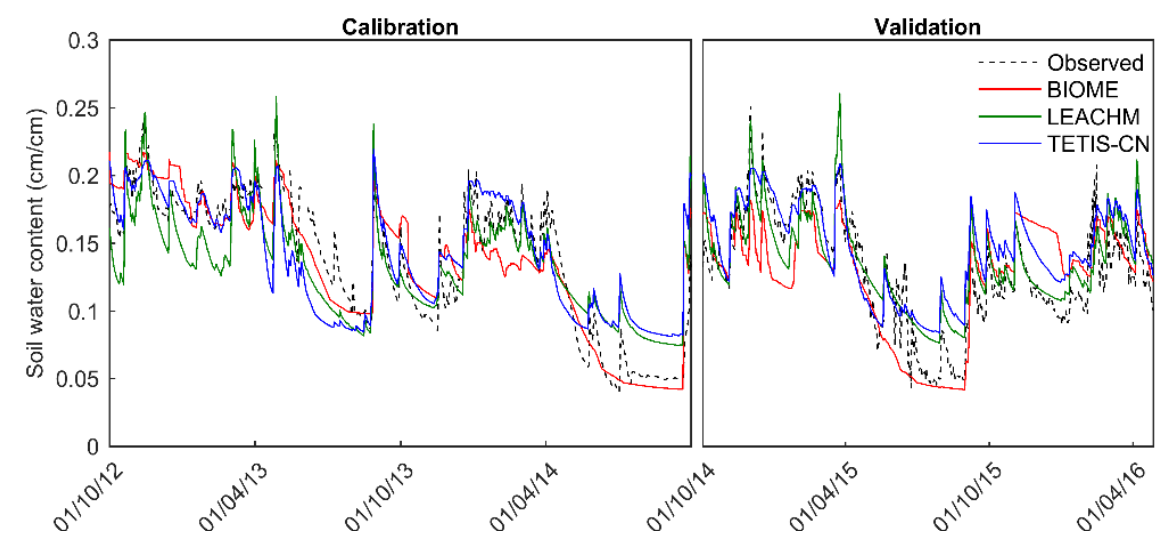

Figure 3-6 I Observed and simulated soil water content.

In terms of soil water content (Figure 3-5 and Figure 3-6), during the calibration period BIOME showed a very good performance, while LEACHM and TETIS showed a good performance (Moriasi et al., 2007). Only LEACHM was able to maintain this performance throughout the validation period, TETIS-CN decreased to a satisfactory performance and BIOME to an unsatisfactory performance (Moriasi et al., 2007). Conversely, only BIOME was able to reproduce the low soil water content observed during the 
Exploring the possibilities of parsimonious nitrogen modelling in different ecosystems warmest and driest months, from June to September approximately. Neither LEACHM nor TETIS-CN were able to reproduce this effect and a significant disagreement between observed and simulated was observed during these months, with a NS index of 0.41 and 0.04 respectively.

Likewise, the three models reproduced transpiration satisfactorily (Moriasi et al., 2007) during both, calibration and validation periods (Figure 3-5 and Figure 3-7). Nonetheless, none was able to reproduce transpiration during the warmest months (June - September) and BIOME worsened its performance during the validation period.

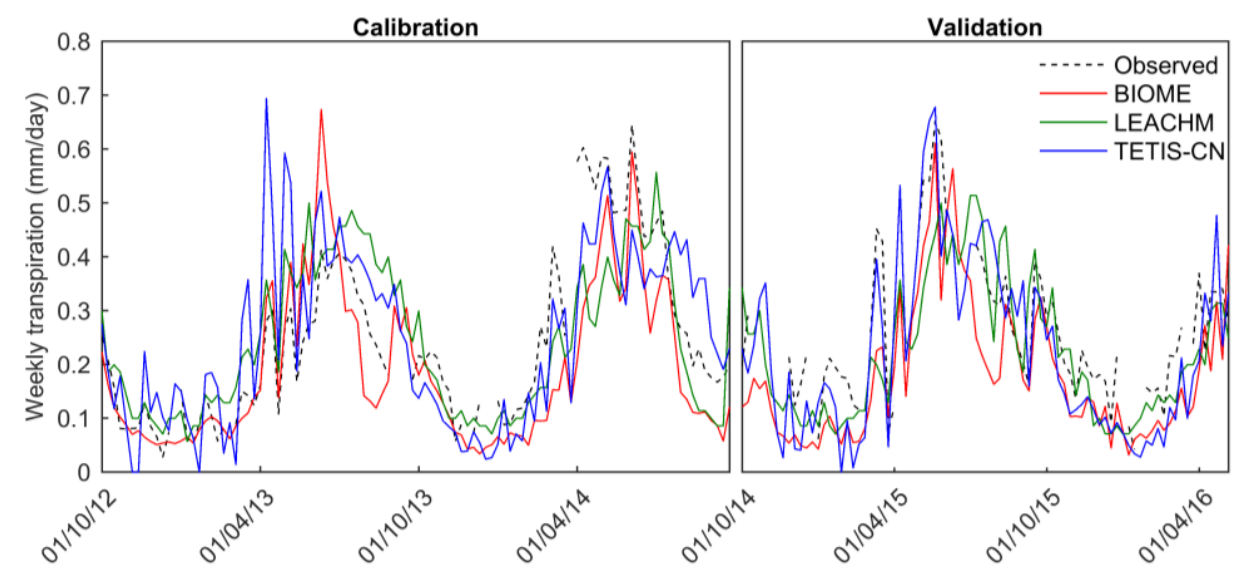

Figure 3-7 I Observed and simulated weekly transpiration.

Table 3-4 I Mean annual water balances in the soil (2012-2015).

\begin{tabular}{lcccc}
\hline \multicolumn{1}{c}{ Flows (mm) } & Obs. & BIOME & LEACHM & TETIS-CN \\
\hline Precipitation & 426.2 & 426.2 & - & 426.2 \\
Interception & 129.2 & 129.5 & - & 81.4 \\
Net precipitation & 297.1 & 296.7 & 297.1 & 344.8 \\
Soil evaporation & - & 34.4 & 64.4 & 118.7 \\
Soil transpiration & - & 49.9 & 68.9 & 49.6 \\
Groundwater transpiration & - & 22.2 & 21.0 & 44.2 \\
Total transpiration & 101.6 & 72.1 & 89.9 & 93.7 \\
Runoff & 4.6 & 4.0 & 3.0 & 0.0 \\
Net percolation & - & 188.5 & 140.8 & 137.5 \\
\hline
\end{tabular}


Exploring the possibilities of parsimonious nitrogen modelling in different ecosystems

Regarding the water balance (Table 3-4), some differences were found mainly in the soil evaporation and transpiration results. Both values were lower when using BIOME, which underestimated total transpiration, leading to a higher percolation value. Nevertheless, the main differences were found in the evapotranspiration partitioning results of TETIS-CN. Despite including interception in the calibration process, TETIS-CN underestimated it, which led to higher soil evaporation. Moreover, the value of groundwater transpiration was also higher with TETIS-CN, however, in any case, these ecosystems showed a strong dependence on groundwater resources. The relative contributions of groundwater transpiration to total transpiration, summer transpiration and total evapotranspiration were calculated, and although TETIS-CN showed a stronger dependence for $Q$. ilex on groundwater resources, BIOME and LEACHM also obtained a strong dependence (Table 3-5).

Table 3-5 I Relative contributions of groundwater transpiration to total transpiration, summer transpiration and total evapotranspiration.

\begin{tabular}{lccc}
\cline { 2 - 4 } & Transpiration & $\begin{array}{c}\text { Transpiration } \\
\text { (summer months) }\end{array}$ & Evapotranspiration \\
\hline BIOME & $30.8 \%$ & $48.7 \%$ & $9.9 \%$ \\
LEACHM & $23.4 \%$ & $42.3 \%$ & $7.4 \%$ \\
TETIS-CN & $47.2 \%$ & $76.4 \%$ & $15.0 \%$ \\
\hline
\end{tabular}

Additionally, the three models reproduced the general carbon and nitrogen dynamics with acceptable accuracy after the calibration process, except for

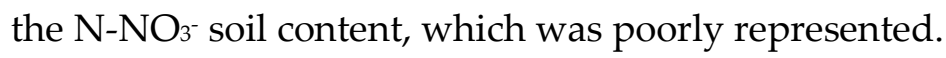

Accumulated mineralization and nitrification were well reproduced taking into account the standard deviation of the measurements (Figure 3-8, Figure 3-9 and Figure 3-10). The three models presented almost all simulated values within the limits of the standard deviation; however, BIOME showed mineralization values below the average and both, BIOME and LEACHM had a low temporal variability which led to a low value of dispersion (Figure 
Exploring the possibilities of parsimonious nitrogen modelling in different ecosystems 3-14) in reproducing mineralization and nitrification. TETIS-CN was able to reproduce the observed values and the trend, but it overestimated mineralization and nitrification from October to November, which correspond with the outlier values in Figure 3-14.

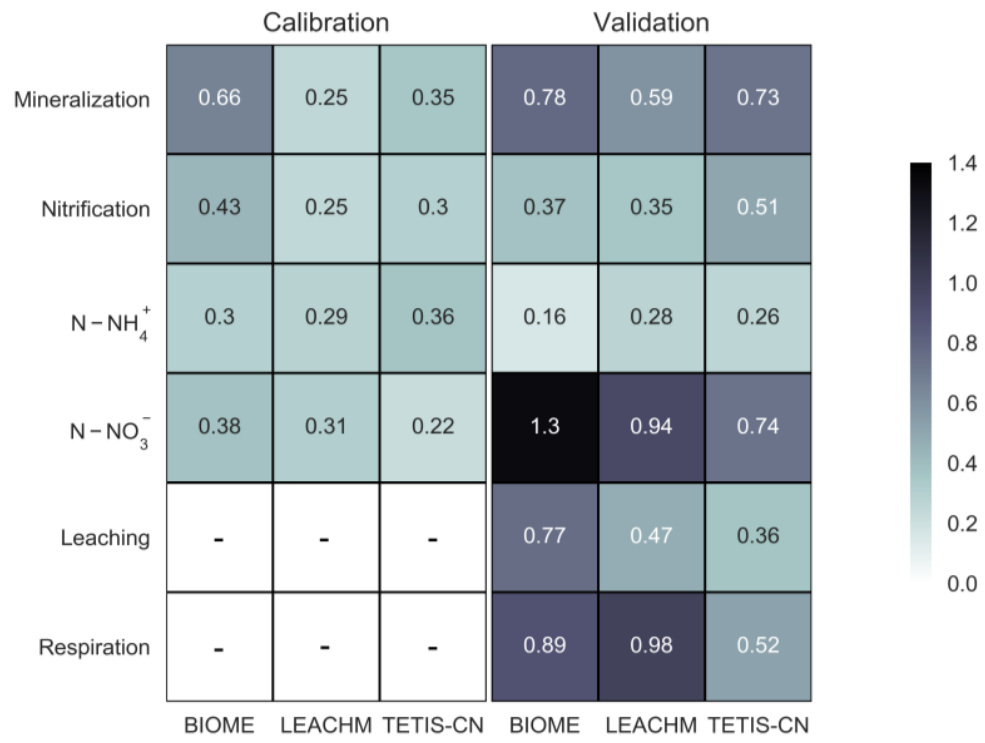

Figure 3-8 | Heatmap representation of accumulated net mineralization, accumulated net

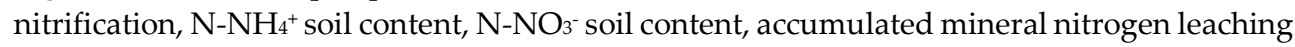
and heterotrophic soil respiration RMSE indices.
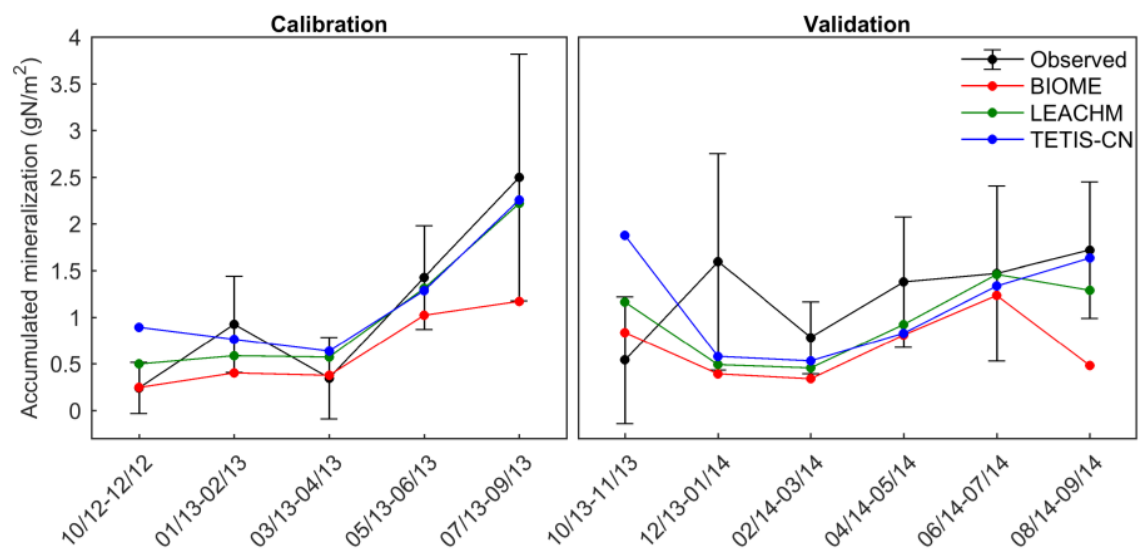

Figure 3-9 I Spatially averaged observed values and simulated values of accumulated mineralization. 
Exploring the possibilities of parsimonious nitrogen modelling in different ecosystems

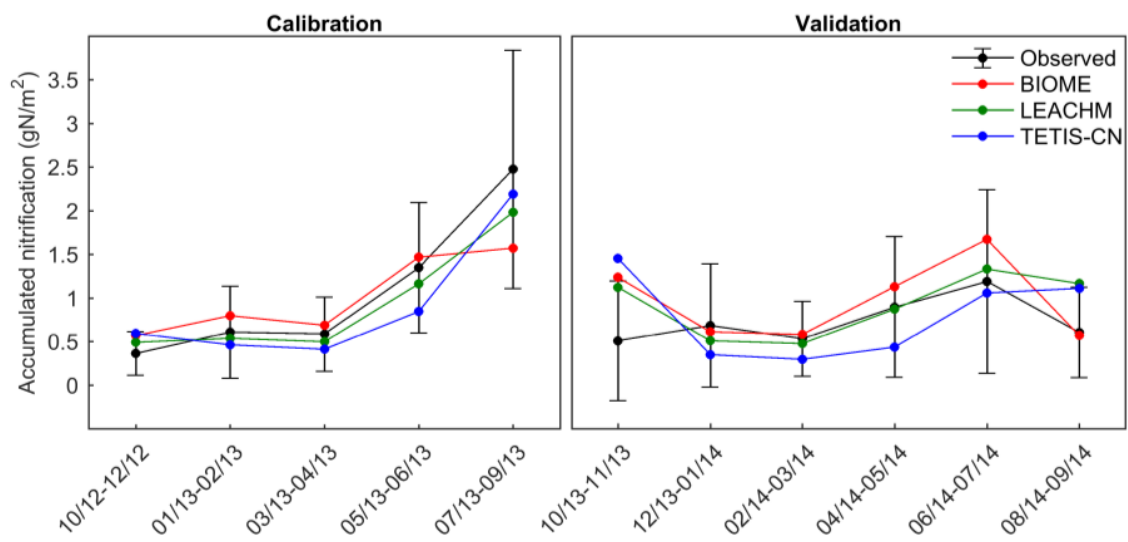

Figure 3-10 | Spatially averaged observed values and simulated values of accumulated nitrification.

Concerning the $\mathrm{NH}_{4}{ }^{+}-\mathrm{N}$ soil content, the three models showed an acceptable performance taking into account the standard deviation of the measurements (Figure 3-8 and Figure 3-11). BIOME and LEACHM presented better results, but both were very stable, showing lower dispersions than the observed one (Figure 3-14). TETIS-CN overestimated the $\mathrm{NH}_{4}{ }^{+}-\mathrm{N}$ soil content during the warmest months, from June to September, but it was able to maintain a median and dispersion similar to the observed one (Figure 3-14).

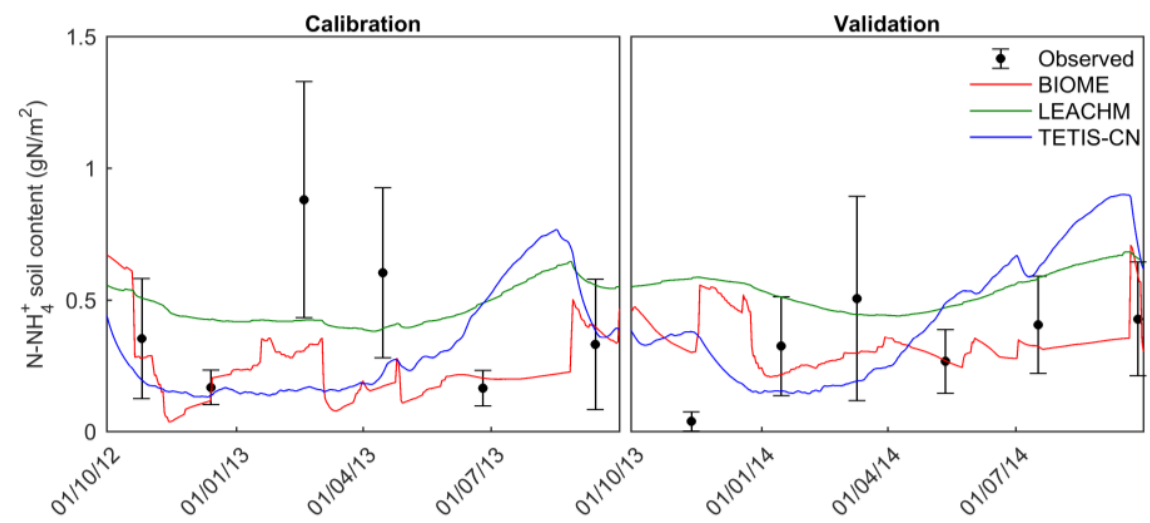

Figure 3-11 | Spatially averaged observed values and simulated values of $\mathrm{N}_{-}-\mathrm{NH}_{4}{ }^{+}$soil content. 
Exploring the possibilities of parsimonious nitrogen modelling in different ecosystems In the case of the $\mathrm{NO}_{3}-\mathrm{N}$ soil content, the performance of the models was poor, especially during the validation period (Figure 3-8 and Figure 3-12). The maximum simulated values and the dispersion were well above the observed ones (Figure 3-14). Specifically, this problem was found during the periods with scarce precipitation events, from June to November of 2013 and from April to September of 2014 (the 2013-2014 hydrological year was very dry, with a precipitation of $271.1 \mathrm{~mm}$, compared to the $581.2 \mathrm{~mm}$ of the 20122013 hydrological year). The best results were obtained by TETIS-CN, but no noteworthy differences were found between the three models.

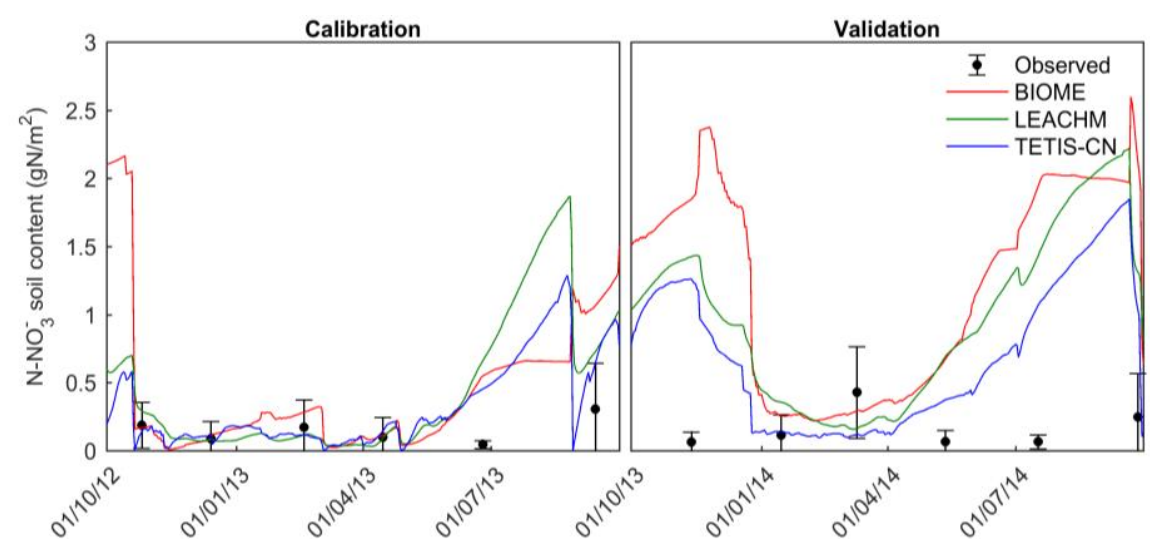

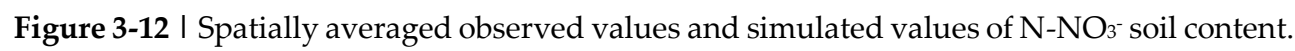

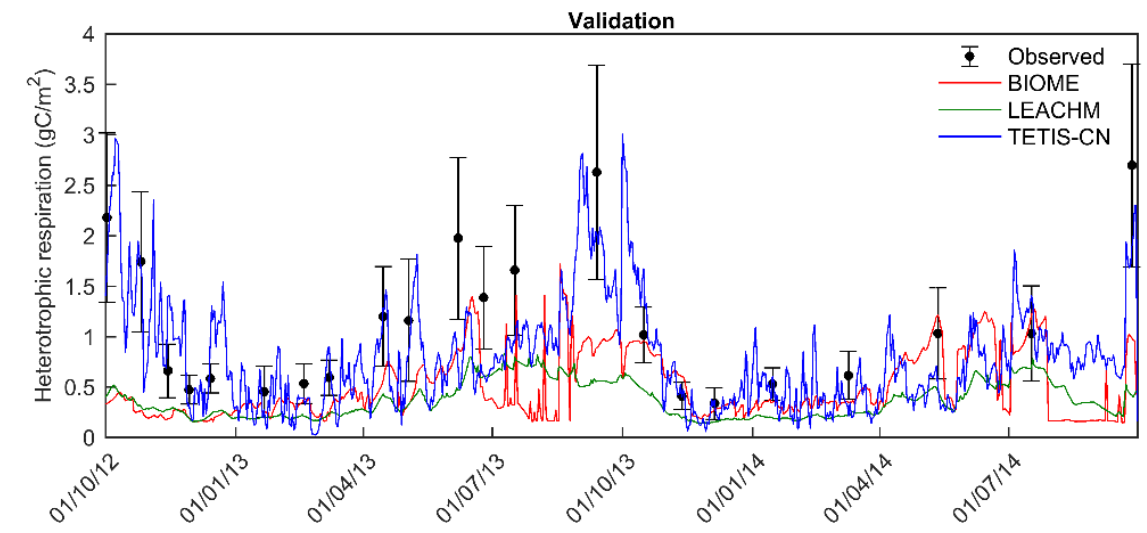

Figure 3-13 I Spatially averaged observed values and simulated values of heterotrophic respiration. 
Exploring the possibilities of parsimonious nitrogen modelling in different ecosystems

Regarding soil respiration, neither BIOME nor LEACHM were able to reproduce the heterotrophic respiration (Figure 3-13). Both models obtained respiration values below the observed ones and they did not reproduce the trend.
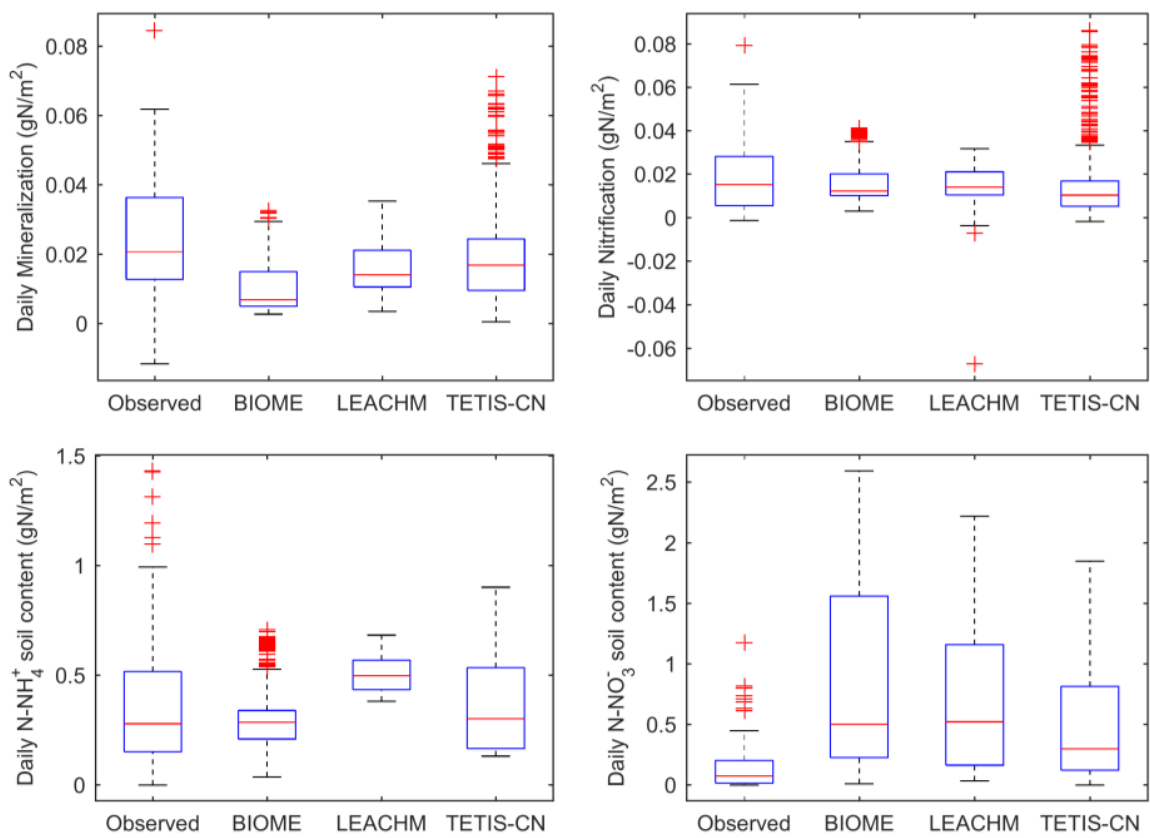

Figure 3-14 I Mineralization, nitrification, $\mathrm{N}_{-} \mathrm{NH}_{4}{ }^{+}$soil content and $\mathrm{N}-\mathrm{NO}_{3}{ }^{-}$soil content box plots of the spatial and temporal observed values and temporal simulated values.

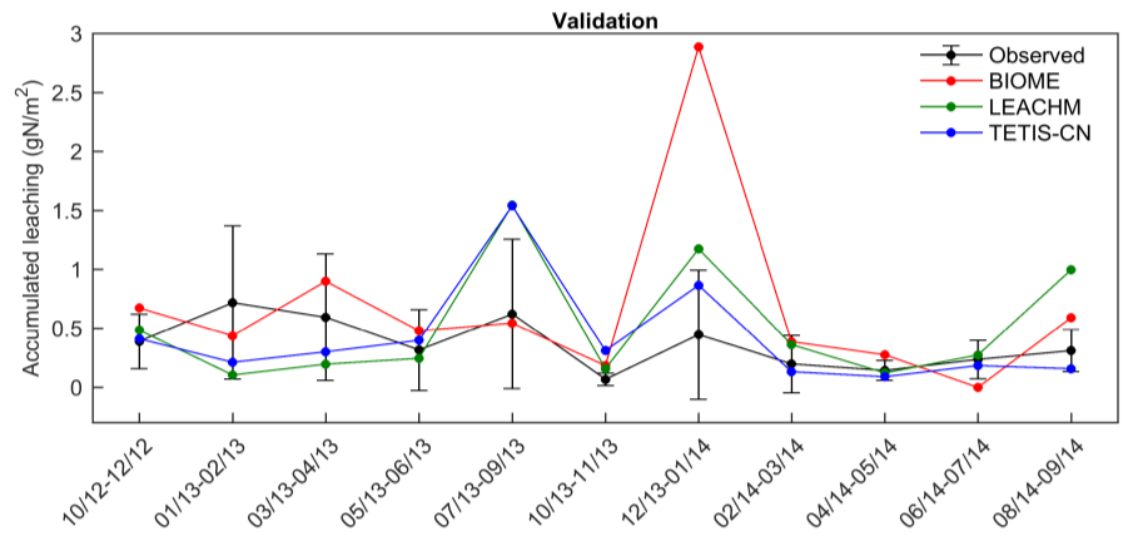

Figure 3-15 I Spatially averaged observed values and simulated values of accumulated mineral nitrogen leaching. 
Exploring the possibilities of parsimonious nitrogen modelling in different ecosystems Accumulated leaching (Figure 3-8 and Figure 3-15) was heavily overestimated during the periods with high precipitation events. Particularly this problem was shown in the case of BIOME, whilst LEACHM and TETIS-CN showed better results.

Table 3-6 I Mean annual carbon and nitrogen balances in the first $15 \mathrm{~cm}$ of soil (2012-2014).

\begin{tabular}{|c|c|c|c|}
\hline Fluxes & BIOME & LEACHM & TETIS-CN \\
\hline Organic carbon plant residue $\left(\mathrm{gC} / \mathrm{m}^{2}\right)$ & 152.75 & 112.95 & 262.53 \\
\hline Heterotrophic soil respiration $\left(\mathrm{gC} \mathrm{m}^{2}\right)$ & 182.86 & 135.48 & 292.21 \\
\hline Organic nitrogen plant residue $\left(\mathrm{gN} / \mathrm{m}^{2}\right)$ & 3.28 & 5.23 & 9.07 \\
\hline Net mineralization $\left(\mathrm{gN} / \mathrm{m}^{2}\right)$ & 3.80 & 5.77 & 6.93 \\
\hline Volatilization (gN/m²) & 0.00 & 0.11 & 0.00 \\
\hline Net nitrification $\left(\mathrm{gN} / \mathrm{m}^{2}\right)$ & 5.66 & 5.34 & 5.28 \\
\hline Denitrification $\left(\mathrm{gN} / \mathrm{m}^{2}\right)$ & 0.33 & 0.11 & 0.26 \\
\hline $\mathrm{N}-\mathrm{NH}_{4}{ }^{+}$plant uptake $\left(\mathrm{gN} / \mathrm{m}^{2}\right)$ & 0.07 & 0.07 & 1.23 \\
\hline $\mathrm{N}-\mathrm{NO}_{3}{ }^{-}$plant uptake $\left(\mathrm{gN} / \mathrm{m}^{2}\right)$ & 0.24 & 1.91 & 2.23 \\
\hline $\mathrm{N}-\mathrm{NH}_{4}{ }^{+}$leaching $\left(\mathrm{gN} / \mathrm{m}^{2}\right)$ & 1.58 & 0.07 & 0.09 \\
\hline $\mathrm{N}-\mathrm{NO}_{3}{ }^{-}$leaching $\left(\mathrm{gN} / \mathrm{m}^{2}\right)$ & 4.36 & 3.44 & 3.08 \\
\hline
\end{tabular}

Finally, some differences were found in the mean annual balances (Table 3-6). These were found in the organic carbon plant residue, heterotrophic soil respiration $\left(\mathrm{CO}_{2}\right.$ release), plant uptake and leaching. BIOME and LEACHM obtained lower values of organic carbon plant residue input and heterotrophic respiration. However, TETIS-CN values of heterotrophic respiration were closer to the observed ones (Figure 3-8 and Figure 3-13), according to the partition between autotrophic and heterotrophic respiration of Hanson et al. (2000). Moreover, BIOME obtained higher values of leaching and lower values of plant uptake, but the leaching values of LEACHM and TETIS-CN were closer to the observed ones (Figure 3-8 and Figure 3-15).

\subsection{Discussion}

Regarding the general water dynamics, BIOME was the only model which heavily worsened its performance during the validation period. This problem may be explained by its high parameter requirements, problem 
known as model over-parameterization. A simple model may not make the best use of data; nonetheless, a model with a high number of parameters may fit the data in the calibration period accurately and then, have a bad performance in the validation period (Walker et al., 2003). Conversely, simpler models as LEACHM and TETIS-CN were unable to reproduce the soil water content and transpiration during the driest and warmest months (June to September), disagreements that may be explained by both models' simple transpiration representation. LEACHM uses weekly averaged potential evapotranspiration values, but its time step is not weekly and it does not consider interception, which leads to a very low pan factor value to compensate the energy used during intercepted water evaporation. Likewise, TETIS-CN divides soil into only two layers and, although the introduction of parameter $\mathrm{LAI}_{0}$ improved its performance, it can be oversimplified. Moreover, neither LEACHM nor TETIS-CN include the Vapour Pressure Deficit (VPD) influence in the calculation of transpiration and in this case, transpiration was mainly explained by variations in VPD (del Campo et al., 2019a).

Regarding the hydrological balance, the results of the models showed how Q. ilex strongly depends on groundwater resources. Hence, given the climate change projections in the Mediterranean region (Spinoni et al., 2018), proper transpiration quantification, as well as correct distribution between the water that flows out of the ecosystem and evapotranspiration, are crucial to face problems related to water resource assessments, forest management or agriculture (Reyes-Acosta and Lubczynski, 2013; Tie et al., 2018).

BIOME and LEACHM reached soil evaporation values close to the range obtained by del Campo et al. (2019a) in this same plot, which was $43-51 \mathrm{~mm}$ year $^{-1}$, and similar groundwater transpiration values, but the $20 \mathrm{~mm}$ difference in soil transpiration was substantial. Nevertheless, BIOME underestimated total transpiration in $30 \mathrm{~mm}$ approximately, which may be 
Exploring the possibilities of parsimonious nitrogen modelling in different ecosystems

explained by the joint hydrology and biogeochemistry calibration process. In the case of BIOME, the hydrology performance of the model may have been decreased by a better biogeochemistry performance because when more than one objective is included in a calibration process, an improvement in the representation of one causes deterioration in the other one (Vrugt et al., 2003). Conversely, TETIS-CN underestimated interception in almost 50 $\mathrm{mm}$ year- $^{-1}$, which led to a very high value of soil evaporation. Its interception modelling is simple and depends on LAI values, which corresponded to corrected satellite LAI values, not being completely representative of the real plot's LAI. As MODIS cell size is $500 \mathrm{~m}$ it includes not only the study plot. In contrast, even though LEACHM does not consider vegetation growth, as it does not simulates the process of interception, it did not show this problem. Additionally, TETIS-CN reached a higher value of groundwater transpiration, but the values obtained by the three models were in the range of previous studies developed under semiarid climates.

The average contribution of groundwater transpiration to total transpiration was $30.8 \%, 23.4 \%$ and $47.2 \%$, while the contribution to total evapotranspiration was $9.9 \%, 7.4 \%$ and $15 \%$, respectively in BIOME, LEACHM and TETIS. These differences seem high, but these values fall within the ranges indicated in previous studies. For example, Hubbert et al. (2001) found that the contribution of weathered bedrock to total transpiration was $70 \%$ in a Pinus jeffreyi plantation in a Mediterranean climate and Hassan et al. (2014) reported that the groundwater contribution to total evapotranspiration was $6.7 \%$ in a mixed Q. ilex and Q. pyrenaica open forest in a semiarid climate. Nonetheless, it should be highlighted that the tree density at this study site is higher than that indicated in Hassan et al. (2014), thus this value may be higher. Moreover, if the contribution of groundwater transpiration to total transpiration is computed in summer months when dependence increased, these values were $48.7 \%, 42.3 \%$ and $76.4 \%$ in BIOME, LEACHM and TETIS, respectively, and were similar to the 
results obtained in previous studies. David et al. (2007) found that groundwater transpiration was $70 \%$ of total transpiration in summer months in a $Q$. ilex and $Q$. suber woodland in a semiarid climate, and in the abovementioned Q. ilex and Q. pyrenaica woodland, Balugani et al. (2017) reported that groundwater transpiration was $50 \%$ of total transpiration. In addition, both models showed similar dynamics. The dependence of $Q$. ilex on groundwater resources increased in the driest year in the three models, which coincides with Eliades et al. (2018) in a Pinus brutia forest in a Mediterranean climate, where groundwater transpiration increased from $65.6 \%$ to $77 \%$ of total transpiration.

In terms of biogeochemistry, the models showed different mean annual values of organic carbon and nitrogen plant residue inputs. BIOME and LEACHM presented a similar value of organic carbon plant residue input, and as in mature natural forests inputs and outputs are generally balanced (Porporato et al., 2003), this value was similar to their heterotrophic soil respiration ( $\mathrm{CO}_{2}$ release). Conversely, TETIS-CN reached higher values, but its heterotrophic soil respiration was closer to the estimated punctual observations, suggesting that BIOME and LEACHM underestimated the organic carbon content of the plant residues, and due to the equilibrium, the heterotrophic soil respiration. This poor performance may be explained by a conceptualization error, a poor description of soil organic matter decomposition or more probably, because no carbon measurement was included in the calibration process. The available observations may not be enough to measure all the characteristics of the system, and thus, their performance may increase if some additional carbon measurements are included as constraints (Uhlenbrook and Sieber, 2005). In fact, in the case of LEACHM, it has been widely used in studies for simulating nitrogen transformation, but these studies rarely consider measured and simulated carbon changes (Mittal et al., 2007) and Asada et al. (2013) modified the model in order to obtain a better description of soil organic matter 
Exploring the possibilities of parsimonious nitrogen modelling in different ecosystems decomposition. Additionally, as a balanced system, the differences in the organic nitrogen plant residue input between models are associated to the different mineralization values, but these differences were only noteworthy for TETIS-CN from October to November, when mineralization was overestimated. Its correction functions of soil water content and temperature vary in a wider range and consequently, BIOME and LEACHM are more stable. However, in both years 2012 and 2013, during the month of October, the temperature was still elevated, and as it rained, mineralization was overestimated in TETIS-CN.

Regarding plant uptake and leaching, the results were very different. Since BIOME includes plant growth, the model simulated root growth towards deep layers ( $8 \mathrm{~m}$ depth), were water was available, reducing the percentage of roots in the first $15 \mathrm{~cm}$ of soil and consequently, the nitrogen plant uptake from these soil layers. Conversely, roots depth in LEACHM and TETIS-CN were smaller, being the percentage in these first $15 \mathrm{~cm}$ of soil higher. LEACHM potential uptake in the first $15 \mathrm{~cm}$ was $26.77 \mathrm{kgN} \mathrm{ha}^{-1} \mathrm{year}^{-1}$, while TETIS-CN was $39.69 \mathrm{kgN} \mathrm{ha}^{-1}$ year- $^{-1}$, resulting in a higher plant uptake and smaller leaching than the other two models. Therefore, all these results suggest that $\mathrm{NO}_{3}-\mathrm{N}$ plant uptake could be underestimated, and consequently the models showed a leaching overestimation (Verburg and Johnson, 2001).

In line with this, $\mathrm{NO}_{3}-\mathrm{N}$ soil content was heavily overestimated during the warm months with scarce precipitation, reinforcing the idea that NO3-N plant uptake was not properly represented, because nitrification measurements were well represented, which is the only $\mathrm{NO}_{3}^{-}-\mathrm{N}$ input considered, denitrification is not a noteworthy flux and leaching was overestimated only during these months. Firstly, this can be explained because in this plot, $Q$. ilex coexists with other species, which were not considered in this case study. These nitrogen field measurements are 
representative of the first $15 \mathrm{~cm}$ of soil, and although $Q$. faginea and $P$. halepensis have deeper root systems (Baquedano and Castillo, 2007), it should be highlighted that J. oxycedrus and J. phoenicea have shallow root systems (Castillo et al., 2002; Gazol et al., 2017), especially the former, which develops most of its roots in the first $15 \mathrm{~cm}$ of soil (Castillo et al., 2002). Therefore, the $\mathrm{NO}_{3}-\mathrm{N}$ plant uptake by other species, not considered here, may be significant. Secondly, the consideration of a fixed daily potential uptake may have led to an oversimplified representation of the nitrogen plant uptake in the case of LEACHM and TETIS-CN. Due to the seasonal variations of VPD in Mediterranean areas, during the warm periods, which coincides with the growing season, transpiration is higher, especially in spring when soil water is not too limiting (Limousin et al., 2009), and consequently Q.ilex $\mathrm{NO}_{3}-\mathrm{N}$ plant uptake also changes seasonally (Bonilla and Rodà, 1992). Thus, considering a fixed daily potential uptake may become an error in the conceptualization that could probably be solved coupling the models to a vegetation growth model. However, in spite of considering vegetation growth, BIOME presented the same problem making the first option more probable.

\subsection{Conclusions}

In this first approach to model the nitrogen cycle, three carbon and nitrogen models, with different conceptualization, complexity and purpose, were calibrated in an experimental Q. ilex forest plot, with two dual objectives. The first and main objective was to contribute to a better understanding and modelling of the nitrogen and carbon cycles in natural ecosystems and their interactions within the soil-plant continuum in semiarid conditions, as well as to test the capability of TETIS-CN to satisfactorily reproduce them. The second was to better understand the hydrological behaviour of facultative phreatophytes, serve as a springboard to improve future hydrological 
Exploring the possibilities of parsimonious nitrogen modelling in different ecosystems models to make them more suitable to be applied in regions covered by such species and consequently improve future predictions.

In this sense, the three models were able to adequately reproduce the hydrological behaviour of $Q$. ilex forest. Soil water content and transpiration measurements were accurately reproduced, although BIOME presented over-parameterization problems and its performance decreased during the validation period. The mean annual hydrological balances obtained were alike and the results showed how $Q$. ilex strongly depends on groundwater resources. In semiarid environments with shallow soils, water transpiration from groundwater is an important water source for these forests, especially in dry years. This dependence in the driest year in this case study increased and, in summer months due to fast soil water depletion, this contribution reached crucial values. Consequently, during prolonged drought periods, such forests will suffer severe effects. Therefore, it is clear that hydrological models applied in semiarid regions should include the groundwater transpiration mechanism because such forests can heavily influence future water availability.

In terms of biogeochemistry, BIOME and LEACHM underestimated the organic carbon plant residue input, and consequently also the heterotrophic soil respiration. This was probably caused because no carbon measurement was included in the calibration process and the available measurements were not enough to measure all the characteristics of the system. Therefore, if no carbon measurement is available the nitrogen performance of these models may be good, but the carbon cycle may not be properly reproduced. In the case of TETIS-CN, the default parameters were able to satisfactorily reproduce the heterotrophic respiration measurements in this case study, but in other applications, it may present this same problem. Regarding to the nitrogen performance of the models, they were able to accurately reproduce mineralization, nitrification and $\mathrm{N}^{-\mathrm{NH}_{4}}{ }^{+}$soil content; nevertheless, $\mathrm{N}^{-\mathrm{NO}_{3}}{ }^{-}$ 
soil content and mineral nitrogen leaching were overestimated, suggesting

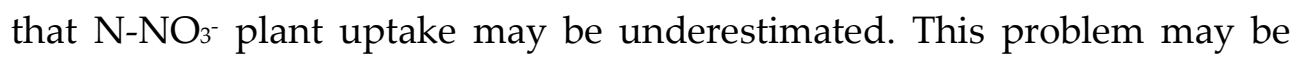
firstly explained because $Q$. ilex coexists with other species with a different behaviour whose plant uptake may be significant. Secondly, in the case of LEACHM and TETIS-CN, a fixed daily potential uptake may not be appropriate to reproduce plant nitrogen uptake, which presents a clear seasonality. Therefore, it is important to consider all the species, although scarce, and in the case of LEACHM and TETIS-CN, to couple them to a vegetation growth model.

Finally, it is worth noting that none of the models stood out from the rest in reproducing the hydrology and the biogeochemistry of this experimental plot. Hence, the similarity between the results demonstrates that TETIS-CN, with a lower number of parameters, is an acceptable tool to be applied in regions covered by phreatophytic species and to reproduce the carbon and nitrogen dynamics in Mediterranean drylands. 



\section{4}

\section{El Mar Menor watershed:} an anthropogenic ecosystem

\subsection{Introduction}

Diffuse pollution is defined as the result of the emissions whose source cannot be traced (La Nauze and Mezzetti, 2019), playing a key role in the degradation of aquatic environments (La Nauze and Mezzetti, 2019; Yongyong Zhang et al., 2016). Agriculture has been recognized as a major source of diffuse pollution (Causapé et al., 2004; Liu et al., 2013; Rao et al., 2009) and its main associated environmental impacts are nitrogen and sediment pollution of water bodies (Zhang et al., 2014). Nitrogen inputs to aquatic environments produce their eutrophication stimulating harmful algal blooms (Álvarez et al., 2017; Le Moal et al., 2019), while sediment inputs contribute to their habitat degradation and biota impairment (Collins et al., 
Exploring the possibilities of parsimonious nitrogen modelling in different ecosystems 2011; Mtibaa et al., 2018). Nevertheless, the use of elevated fertilizer doses (Pardo et al., 2017; Poch-Massegú et al., 2014) to increment crop yield and poor support conservation practices (Panagos et al., 2015) are still a common practice in agricultural areas. Both produce a direct impact on water quality through the nitrogen surplus and soil erosion, but the latter also produces an indirect impact contributing to soil degradation through the removal of the topsoil and finest fraction of soils, where organic matter and nutrients are concentrated (García-Ruiz et al., 2015; Merchán et al., 2018), which usually entails a crop yield decline (García-Ruiz et al., 2015).

As a result, many water policy instruments have been developed (Ingram, 2008), including the Water Framework Directive in Europe (2000/60/EC), with the objective of achieving good ecological and chemical conditions in water bodies. However, water bodies pollution continues being a problem in many parts of the world, an ongoing concern within Europe (Harrison et al., 2019) and, moreover, it is expected to be exacerbated. The use of fertilizers is expected to increase due to the growing needs of food, fibre, feed and biofuel as a consequence of population growth and the improvement in living standards (Chukalla et al., 2018; Tilman et al., 2011, 2002), and additionally, climate change is expected to have an impact on hydrology and diffuse nutrient export from agricultural areas (Wagena and Easton, 2018). Thus, the development of strategies to improve the sustainability of intensive agricultural production is a major challenge (Pradhan et al., 2015; Quemada et al., 2013).

In that sense, best management practices have been recognized as effective tools for preventing or minimizing pollution from agricultural areas (Chiang et al., 2014; Giri and Nejadhashemi, 2014). These include soil and water conservation practices and management techniques (Sharpley et al., 2006) whose objective is to control and reduce the sediments and nutrients sources. Nonetheless, the main problem is that their effectiveness varies between sites 
and soil type and, accordingly, it is unfeasible to test them through field studies because it is costly and time consuming (Qiu et al., 2018; Sith et al., 2019; Strauch et al., 2013). Therefore, water quality models and model based scenario analysis are useful tools to assess their impact and identify the appropriate strategy at the watershed scale for the development of watershed management plans (Cavero et al., 2012; Dechmi and Skhiri, 2013; Ullrich and Volk, 2009).

Hence, in this second approach the effectiveness of several management practices has been assessed with the distributed conceptual hydrological model TETIS (Francés et al., 2007), for which a nitrogen sub-model has been developed, TETIS-N. The general conceptualization of TETIS-N is based on INCA-N (Wade et al., 2002), however, it includes new developed improvements and the incorporation of a growth module based on EURotate_N (Rahn et al., 2010), which allows crop growth simulation, a very important factor in agricultural areas. The study area focused on the southernmost Mar Menor basins dominated by agricultural lands and characterized by a semiarid climate. The Mar Menor is one of the largest saltwater coastal lagoons of Europe, which provides aesthetic, touristic, fishing and recreational opportunities for the city, and has a high environmental value. These value has been internationally recognised by including it on the List of Wetlands of International Importance (RAMSAR) and on the List of Specially Protected Areas of Mediterranean Importance (SPAMIs), and additionally, declaring it a Site of Community Importance (SCI) and a Special Protection Area for Birds (SPA). However, these protection regulations have failed to prevent its deterioration (GarciaAyllon, 2018). The Mar Menor lagoon continues under threat due to point and nonpoint pollution and even the users are well aware of the impacts and risks (Velasco et al., 2018). Urbanization, tourism and intensive agricultural activity are the main causes of pollution (García-Ayllón and Miralles, 2014; Rey et al., 2013), although, as the Mar Menor watershed is one of the main 
Exploring the possibilities of parsimonious nitrogen modelling in different ecosystems horticultural productive areas in Europe (Álvarez-Rogel et al., 2006), diffuse nutrient export from the agricultural landscape is the main environmental impact (Perni and Martínez-Paz, 2013).

Accordingly, several studies, focused on the Mar Menor, have been developed (e.g., De Pascalis et al., 2012; León et al., 2017; Tsakovski et al., 2009; Velasco et al., 2006), nonetheless, despite the threat that it suffers, little attention has been paid to the evaluation of mitigation measures (e.g., Alcolea et al., 2019; Perni and Martínez-Paz, 2013). Recently, JiménezMartínez et al. (2016) recognized groundwater discharge as the main source of nutrients that polluted the lagoon, establishing the implementation of improved agricultural practices to reduce nitrate leaching as a critical measure, and Alcolea et al. (2019) assessed two mitigation measures aiming to reduce this groundwater nutrient discharge, the installation of new drains to intercept groundwater discharge and a distributed groundwater pumping. Unfortunately, Alcolea et al. (2019) showed that both measures were able to reduce groundwater discharge, and consequently, nitrate discharge, however, none was able to maintain nitrate discharge below tolerable levels. Hence, additional and complementary measures, especially focused on reducing nitrogen leaching, are necessary.

Within this context, the proposed management practices are: three scenarios willing to change the field operation management strategies (contour farming, contour farming with grassy field borders and contour farming with hedgerow field borders), two coastal line buffers (100 and $500 \mathrm{~m}$ ), whose effectiveness has been scarcely discussed, a new fertilizer management strategy, based on a simple soil-plant nitrogen mass balance, and this fertilizer management strategy combined with a change in the productive cultivation system from a three-crop rotation to a two-crop rotation, which has also been scarcely discussed. Following, based on this introduction, the objective of this second approach is dual. Firstly, it aims to 
Exploring the possibilities of parsimonious nitrogen modelling in different ecosystems evaluate the impact of several management practices on nitrogen and sediment loads, as well as their impact on horticultural crop yield. Secondly, it also aims to serve as a springboard to identify an appropriate management strategy at the watershed scale, which will be useful to be applied to another watershed with similar characteristics and similar problems, since few studies have been developed in semiarid and coastal environments (Hashemi et al., 2016).

\subsection{Study area}

In this approach, the study area has been focused on the southernmost Mar Menor basins (Figure 4-1), where only agricultural influence exists, and located in southeast Spain. This area covers $100.1 \mathrm{~km}^{2}$ and is divided into 88 basins ( 66 of which are small coastal basins) and 6 endorheic basins. All basins are ephemeral rivers, and no gauging station is located in this area.

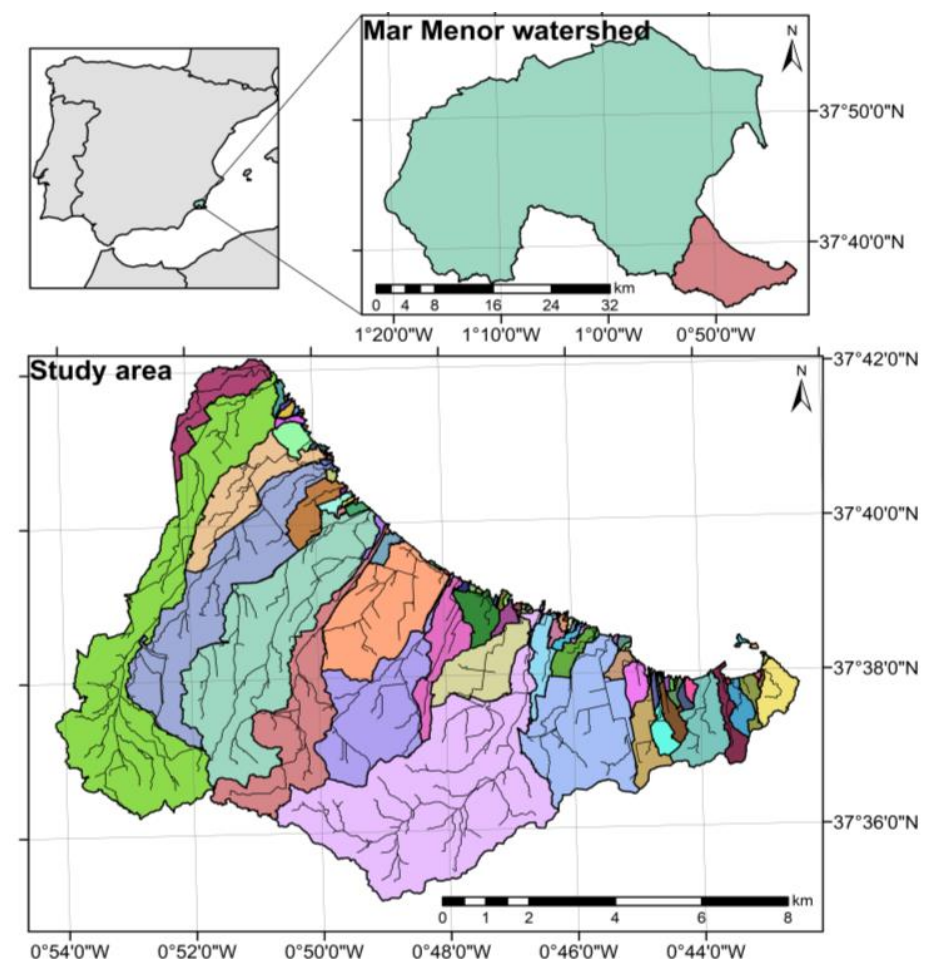

Figure 4-1 I Location of the study area. 
Exploring the possibilities of parsimonious nitrogen modelling in different ecosystems The altitude ranges from 0 to $393 \mathrm{~m}$ a.s.l. (Figure 4-2) and the climate is semiarid, with a mean annual precipitation of $291 \mathrm{~mm}$, a mean annual reference evapotranspiration of $1061 \mathrm{~mm}$ (Hargreaves and Samani, 1985) and a mean annual temperature of $18.7^{\circ} \mathrm{C}$ (for the period 1971-2016). Soils are mainly Xerosols, Arenosols and Lithosols with loam and clay loam being the most frequent textural classes. The underlying materials are mainly Quaternary-aged with a thickness ranging from 50 to $150 \mathrm{~m}$ and outcrops of Pliocene- and Miocene-aged materials.

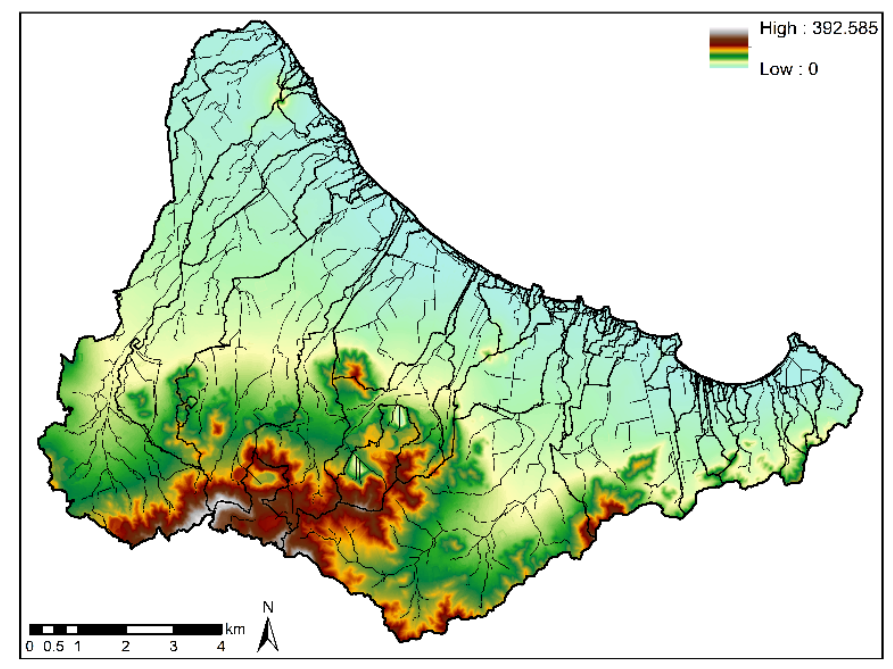

Figure 4-2 I Digital elevation model of the study area.

Most of the area is dedicated to agricultural land use (53.3\%), being citrus trees and horticultural crops the dominant land uses (Figure 4-3 and Table $4-1$ ). In the case of horticultural crops, the most common agricultural practice consists of an annual three-crop rotation between broccoli, melon and lettuce. Additionally, current agricultural management practices in this area consist in the application of high fertilizer doses (common problem in Spain's irrigated Mediterranean areas (Calatrava et al., 2011; De Paz and Ramos, 2002)) by daily fertigation with drip irrigation system and no contouring, which has led to huge nitrate-related problems. Nitrate 
groundwater concentrations are generally above the $50 \mathrm{mg} \mathrm{NO}^{3} \mathrm{~L}^{-1}$ limit of the Nitrate Directive of the European Commission (91/676/EEC).

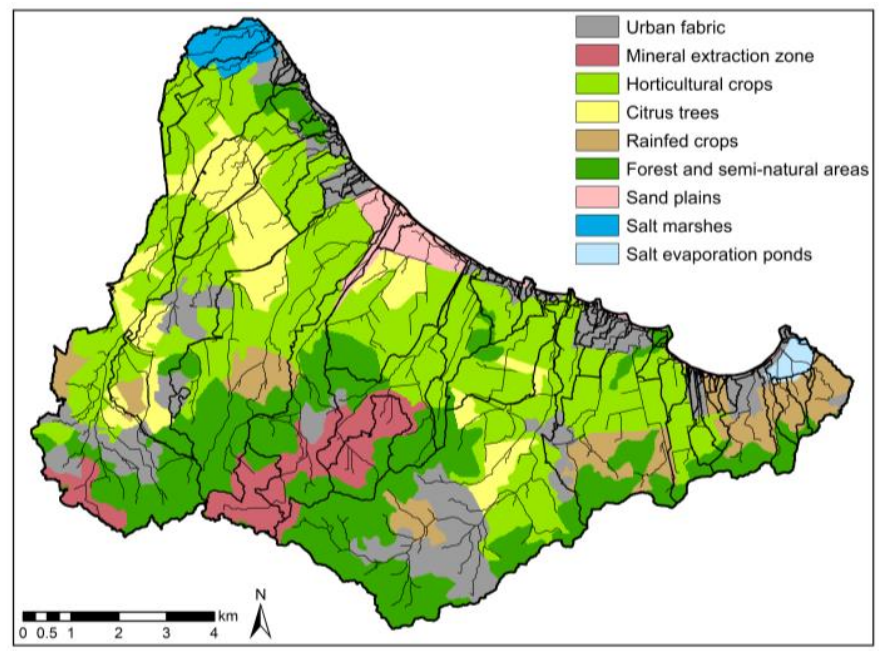

Figure 4-3 I Simplified land use map of the study area (CORINE Land Cover 2006).

Table 4-1 I Area (\%) for each land use in the study area.

\begin{tabular}{lc}
\hline \multicolumn{1}{c}{ Land use } & Area (\%) \\
\hline Continuous urban fabric & 3.33 \\
Discontinuous urban fabric & 5.20 \\
Mineral extraction sites & 6.01 \\
Dump sites & 0.83 \\
Construction sites & 0.77 \\
Sport and leisure facilities & 2.44 \\
Non-irrigated arable land & 4.50 \\
Permanently irrigated arable land & 36.67 \\
Fruit trees and berry plantations & 9.48 \\
Complex cultivation patterns & 1.50 \\
Principally agricultural land & 1.17 \\
Coniferous forest & 2.35 \\
Sclerophylous vegetation & 16.04 \\
Transitional woodland & 3.16 \\
Beaches, dunes and sand plains & 2.17 \\
Sparsely vegetated areas & 2.21 \\
Salt marshes & 1.56 \\
Salt evaporation ponds & 0.61 \\
\hline
\end{tabular}


Exploring the possibilities of parsimonious nitrogen modelling in different ecosystems

Hence, to cope with the problematic of the diverse land use distribution, a distributed model, which divides the area into cells, downscales the environmental variables to each cell, simulates the state variable in each cell and finally, assembles the results for the complete basin, stands out as an appropriate tool.

\subsection{TETIS-N model}

TETIS-N is a hydrological distributed conceptual model composed of three sub-models: hydrology (Francés et al., 2007), sediment transport (Bussi et al., 2014, 2013) and nitrogen transport and transformation (developed and described in this thesis). The three sub-models are described as follows.

\subsubsection{Hydrological sub-model}

In TETIS-N, each cell is hydrologically represented by means of five vertical connected tanks (Figure 4-4) and a channel tank. $\mathrm{T}_{0}$ represents the interception process (only evaporation) and $\mathrm{T}_{1}$ refers to the soil static storage (i.e., below field capacity), being evapotranspiration the only output from this tank. Then, water moves downwardly as long as the tank vertical outflow capacity is not exceeded. $T_{2}$ is the superficial water storage, and $T_{3}$ is the gravitational storage (i.e., above field capacity), both representing the surface runoff process (overland flow and interflow, respectively). The last tank, $\mathrm{T}_{4}$, represents the aquifer. These three tanks act as simple linear reservoirs and their outflows are routed to the corresponding tank of the downstream cell. $T_{5}$ represents the river netflow.

Two thresholds characterise the horizontal conceptualization of TETIS-N, which divide the cells into hillslope, gully and river channel cells (Figure 4-5). The overland flow and interflow, are routed to the $T_{2}$ and $T_{3}$ tanks of the downstream cell, unless they reach a gully cell. In that case, the flows are routed to the river channel tank, $T_{5}$. Likewise, the base flow is routed to the downstream $\mathrm{T}_{4}$ cell, until it reaches a river channel cell, in which case, it is 
Exploring the possibilities of parsimonious nitrogen modelling in different ecosystems also routed to $T_{5}$. Flow routing along the stream river network is computed using the Geomorphologic Kinematic Wave methodology (Francés et al., 2007).

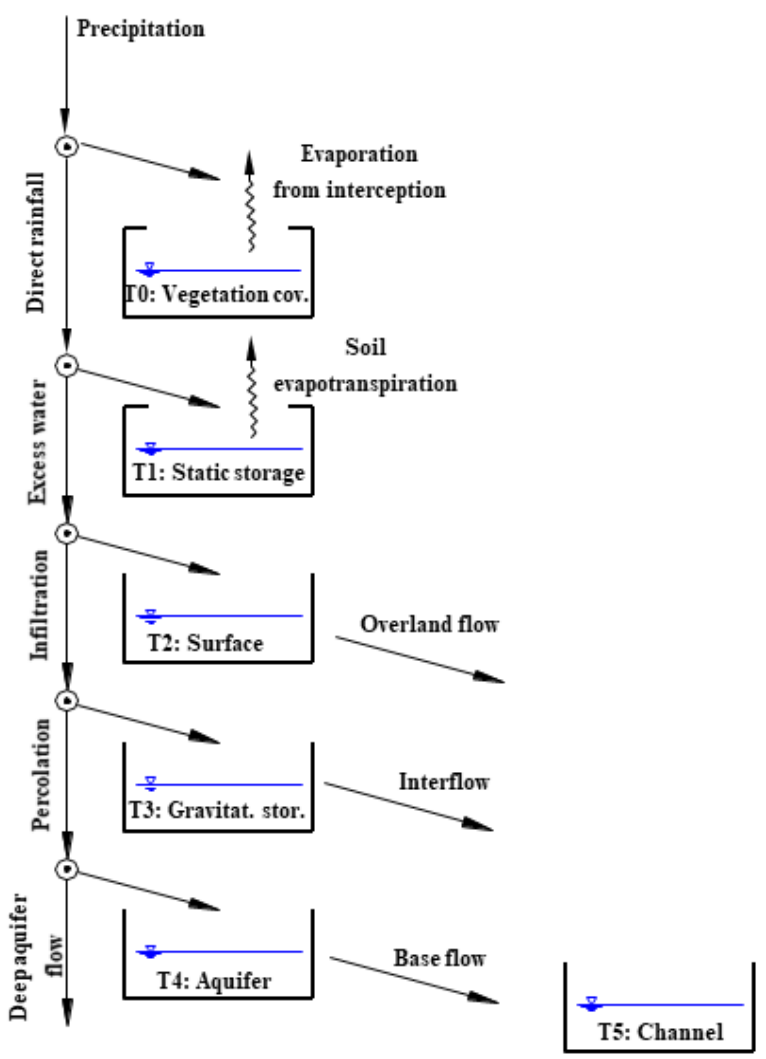

Figure 4-4 I Vertical hydrological conceptualization of TETIS-N.

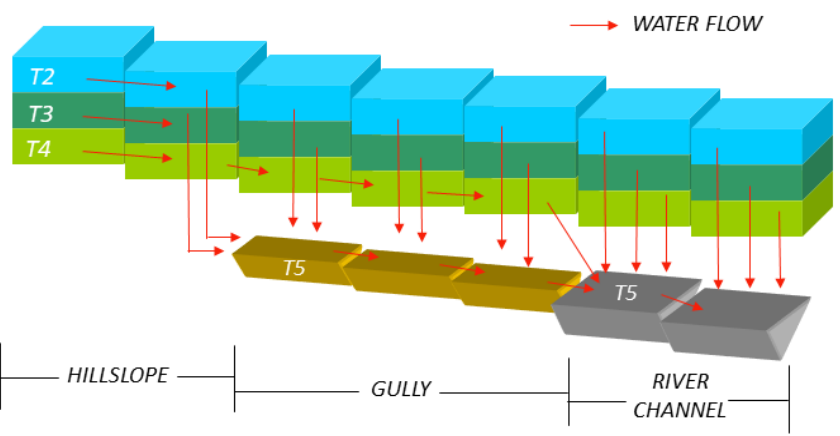

Figure 4-5 I Horizontal hydrological conceptualization of TETIS-N. 


\subsubsection{Sediment sub-model}

In the sediment sub-model, each cell is represented by means of three vertical tanks: parental material, deposited and suspended (Figure 4-6). Sediment particles are divided in the model into sand, silt and clay; each one with a representative grain diameter and settling velocity. Sediment availability and sediment transport capacity control the processes of sediment production, transport and deposition.

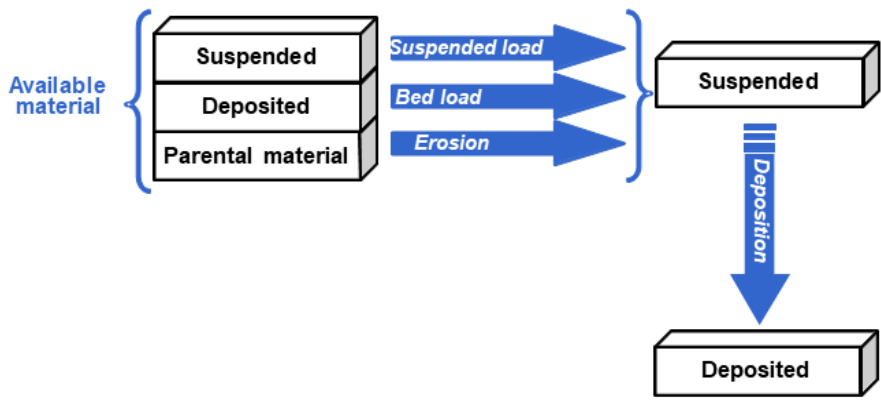

Figure 4-6 I Sediment conceptualization of TETIS-N.

Hillslope sediment transport capacity is calculated by means of the modified Kilinc and Richardson equation (Julien, 2010; Kilinc and Richardson, 1973). This equation incorporates the effect of the soil characteristics, the land use and the agricultural management practices by means of the soil erodibility factor (K-factor), the cover-management factor (C-factor) and the support practice factor (P-factor) of the Universal Soil Loss Equation (USLE) (Wischmeier and Smith, 1978). This transport capacity is firstly used to transport suspended sediments downstream, then, the residual transport capacity is used to mobilize the deposited sediments and finally to erode the parent soil (Figure 4-6). River channel transport is computed by means of the Engelund and Hansen equation (Engelund and Hansen, 1972). Likewise, the calculated transport capacity is firstly used to route suspended sediments downstream and the residual transport capacity is used to mobilize deposited sediments. 


\subsubsection{Nitrogen sub-model}

The general conceptualization of TETIS-N nitrogen sub-model is based on the formulation of the model INCA-N (Wade et al., 2002), however, it presents new developed improvements and it includes a crop growth module based on EU-Rotate_N (Rahn et al., 2010). On the one hand, INCA$\mathrm{N}$ is a spatially distributed model, which simulates the nitrogen processes at catchment scale. On the other hand, EU-Rotate_N is a plot scale model, which incorporates crop growth and thus, it makes a more precise description of the nitrogen crop uptake. Therefore, in TETIS-N the nitrogen cycle is simulated just as in INCA-N, although some new features were developed within this thesis. Firstly, TETIS-N not only incorporates the modelling of $\mathrm{NH}_{4}{ }^{+}$and $\mathrm{NO}_{3}{ }^{-}$, but also the modelling of the organic nitrogen, secondly, it considers $\mathrm{NH}_{4}{ }^{+}$soil sorption, and finally, this sub-model has been also coupled to the sediment sub-model. This last improvement allows to simulate not only the dissolved nitrogen transport, but also the transport of the nitrogen fixed to sediments. Moreover, in order to improve the simulation of the nitrogen plant uptake in the agricultural areas, the model uses the formulation employed in EU-Rotate_N to simulate crop growth, and consequently, crop yield.

In the nitrogen sub-model, each cell is represented by means of ten tanks (Figure 4-7). Four tanks and seven processes represent the nitrogen cycle within the soil. Mineralization, immobilization, nitrification and denitrification are represented by first-order kinetics. As a matter of example, the mineralization process is described as:

$$
\operatorname{Min}=k_{\text {Min }} f(t) f_{\text {Min }}(\vartheta) \operatorname{OrgN}
$$

where $\mathrm{Min}$ is the $\mathrm{NH}_{4}{ }^{+}$mineralized mass $\left(\mathrm{kgN}\right.$ day-1), $k_{\text {Min }}$ is the mineralization rate constant $\left(\right.$ day $\left.^{-1}\right), f(\vartheta)$ and $f(t)$ are dimensionless terms accounting for the soil water content and soil temperature influence and $\operatorname{OrgN}$ is the organic nitrogen content $(\mathrm{kgN})$. As volatilization is mainly a $\mathrm{pH}$ - 
Exploring the possibilities of parsimonious nitrogen modelling in different ecosystems

dependent process, for simplicity, it is described by a first-order kinetic without temperature or water content correction. $\mathrm{NH}_{4}{ }^{+}$adsorption and desorption by clay colloids is also modelled in the simplest way, by a linear sorption isotherm:

$$
c_{s}=k_{d} c_{L}
$$

where $k_{d}$ is $\mathrm{NH}_{4}{ }^{+}$distribution coefficient $\left(\mathrm{dm}^{3} \mathrm{~kg}^{-1}\right), c_{s}$ is $\mathrm{N}-\mathrm{NH}_{4}{ }^{+}$concentration in the sorbed phase $\left(\mathrm{mgN} \mathrm{kg}^{-1}\right)$ and $c_{L}$ is $\mathrm{N}_{-} \mathrm{NH}_{4}^{+}$concentration in solution $\left(\mathrm{mgN} \mathrm{dm}^{-3}\right)$. In addition, four tanks and two processes (nitrification and denitrification) represent the in-stream nitrogen cycle. These processes are also represented by first-order kinetics, but only accounting for the temperature influence, $f(t)$. The nitrogen cycle in the aquifer is represented by two tanks and no process is simulated because not biological activity is considered.

Soil water correction functions are based on those proposed in Brady and Weil (2002). Mineralization and immobilization are corrected according to:

$$
f(\vartheta)_{\text {Min }}=\left\{\begin{array}{cc}
0 & \vartheta \leq \vartheta_{w p} \\
\left(\vartheta-\vartheta_{w p}\right) /\left(\vartheta_{f c}-\vartheta_{w p}\right) & \vartheta_{w p} \leq \vartheta \leq \vartheta_{f c} \\
\vartheta_{f c} / \vartheta & \vartheta>\vartheta_{f c}
\end{array}\right.
$$

where $\vartheta$ is soil moisture $\left(\mathrm{cm} \mathrm{cm}^{-1}\right), \vartheta_{\text {wp }}$ is soil moisture at wilting point $(\mathrm{cm}$ $\left.\mathrm{cm}^{-1}\right)$ and $\vartheta_{f c}$ is soil moisture at field capacity $\left(\mathrm{cm} \mathrm{cm}^{-1}\right)$. The nitrification process is corrected according to:

$$
f(\vartheta)_{N i t}=\left\{\begin{array}{cc}
\vartheta / \vartheta_{f c} & \vartheta \leq \vartheta_{f c} \\
(1-\vartheta) /\left(1-\vartheta_{f c}\right) & \vartheta>\vartheta_{f c}
\end{array}\right.
$$

and finally, the process of denitrification is corrected according to:

$$
f(\vartheta)_{D e}=\left\{\begin{array}{cc}
0 & \vartheta \leq \vartheta_{f c} \\
\left(\vartheta-\vartheta_{f c}\right)^{2} /\left(1-\vartheta_{f c}\right)^{2} & \vartheta>\vartheta_{f c}
\end{array}\right.
$$

The temperature correction function (Wade et al., 2002) for both soil and instream parameters is: 


$$
f(t)=\beta^{\left(T-T_{o p t}\right)}
$$

where $\beta$ is a constant with a typical value of $1.047, T$ is air or soil temperature $\left({ }^{\circ} \mathrm{C}\right)$ and $T_{\text {opt }}$ the optimum temperature $\left({ }^{\circ} \mathrm{C}\right)$, which usually has a value of $20^{\circ} \mathrm{C}$.

Nitrogen plant uptake is divided into two steps (Porporato et al., 2003). The passive uptake is calculated as an advective movement proportional to the transpiration flux, which is calculated through the vegetation cover factor. If this uptake does not satisfy the requirement (i.e., daily potential uptake), a diffusive component is considered (i.e., active uptake). This active uptake is proportional to the nitrogen content and a diffusion coefficient. The daily potential nitrogen uptake is considered constant during the year and it is calculated from the annual nitrogen demand. However, in agricultural areas with non-woody crops, the model has a specific crop growth sub-model, which calculates a daily potential uptake depending on the crops' development.

This crop growth sub-model (Rahn et al., 2010) simulates any number of crops in a yearly rotation. The simulated state variable is dry matter and each day, the increment in dry matter is corrected accounting for the influence of air temperature and, water and nitrogen availability. Daily nitrogen plant uptake is calculated according to the minimum nitrogen content in the crop for maximum growth (i.e., critical nitrogen value).

The dissolved nitrogen transport to the downstream cell is carried out according to the horizontal hydrological connection between tanks and only considering advective movement. The nitrogen fixed to sediments is considered to be only fixed to the clay fraction and it is mobilized according to the clay sediment fraction that is eroded, deposited or mobilized to the downstream cell. 


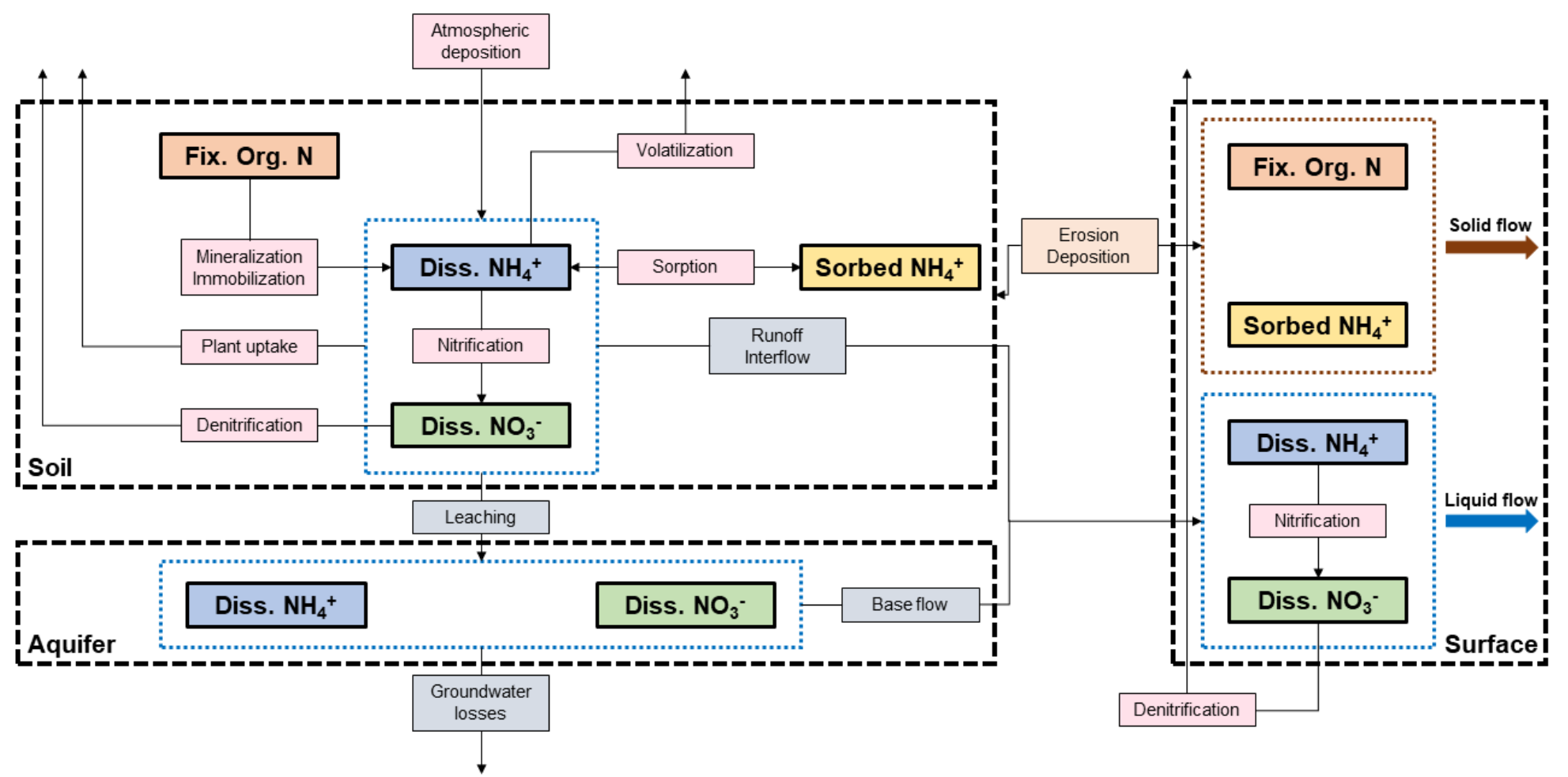

Figure 4-7 I Nitrogen conceptualization of TETIS-N. 


\subsubsection{Model parameters and split-parameter structure}

In order to simplify the calibration, the hydrological and sediment submodels of TETIS-N present a split-parameter structure (Francés et al., 2007). The parameters maps and the potential evapotranspiration data series act as modal values, where the absolute value of each cell is not important, which is important is a correct spatial distribution (or temporal in the case of the potential evapotranspiration). These modal values are latter corrected by means of a correction factor during the calibration process. Therefore, instead of calibrating the number of parameter multiplied by the number of cells, only the correction factors should be calibrated.

In the case of the hydrological sub-model, nine correction factors are used: maximum static storage, evapotranspiration, infiltration, hillslope surface velocity, percolation, interflow hydraulic conductivity, deep percolation, base flow hydraulic conductivity and flow velocity (Table B-1).

The sediment sub-model is represented by three correction factors, one for each transport capacity (hillslope, gullies and channel) (Table B-2). Each time step, in each cell, a transport capacity is calculated and this transport capacity is corrected by multiplying it by the corresponding correction factor.

In the case of the nitrogen sub-model, the parameters depend on the land use type because there are not significate differences in their spatial distribution within the same land use. Hence, the split-parameter structure is only used in the case of the $\mathrm{NH}_{4}{ }^{+}$distribution coefficient parameter map, which depends on the content and type of clay and thus, presents a correction factor. The other parameters are defined for each land use. Therefore, the nitrogen sub-model presents one correction factor, which affects the $\mathrm{NH}_{4}{ }^{+}$distribution coefficient, three temperature correction parameters (Table B-4), eight land use specific parameters, mineralization rate, immobilization rate, volatilization rate, nitrification rate, denitrification rate, diffusion coefficient, annual nitrogen potential uptake and nitrogen 
Exploring the possibilities of parsimonious nitrogen modelling in different ecosystems

form preference (Table B-5), and two in-stream parameters, nitrification and denitrification rates (Table B-3). Additionally, the crop growth sub-model requires information about plant and harvest date, initial and final crop dry matter, initial and final crop cover factor, base temperature, nitrogen form preference and a and b crop-specific coefficients (Rahn et al., 2010) (Table B6).

\subsection{Model setup}

\subsubsection{Initial parameter estimation}

The hydrological sub-model requires information related to topography, land use, soil and geology. The digital elevation model (DEM) was obtained from the Spanish Centro Nacional de Información Geográfica (CNIG) with a $5 \mathrm{~m}$ grid spacing. Although computation time significantly increased (4.003.244 cells had to be simulated), a fine discretization was required in order to adequately reproduce the river network.

Slope, flow direction and flow accumulation maps were derived from the DEM, while hillslope surface velocity was calculated from the slope map according to Francés et al. (2007). The CORINE Land Cover 2006, was used as land use map and the seasonal variation of actual evapotranspiration for each land use was introduced to the model by means of the crop coefficient, calculated according to Allen et al. (1998).

The maximum static storage (Figure 4-8) was calculated as:

$$
H_{u}=\text { Surf.Storage }+A W C \min [\text { Rdepth } ; R O O]
$$

where Surf.Storage is the surface storage $(\mathrm{mm}), R O O$ is the depth available to roots (m) (Hiederer, 2013), Rdepth is roots' depth (m) and AWC is soil available water content $(\mathrm{mm} / \mathrm{m})$, that is, the difference between field capacity and wilting point. These were derived from the soil texture data (Ballabio et al., 2016) and applying the Clapp and Hornberger (1978) equation: 


$$
\psi=\psi_{a e}\left(\frac{n}{H}\right)^{b}
$$

where $\psi$ is matric potential (Mpa), $\psi_{a e}$ is the matric potential of the air entry (Mpa), $n$ is porosity, $b$ is an index related to the distribution of the porosity and $H$ is the water content $(\mathrm{m} / \mathrm{m}) .0 .015 \mathrm{Mpa}$ and $3 \mathrm{MPa}$ where used for the matric potential at field capacity and wilting point respectively. Clapp and Hornberger (1978) also proposed values for the matric potential of the air entry, the porosity and the index related to the distribution of the porosity according to the soil texture. These proposed values where used.

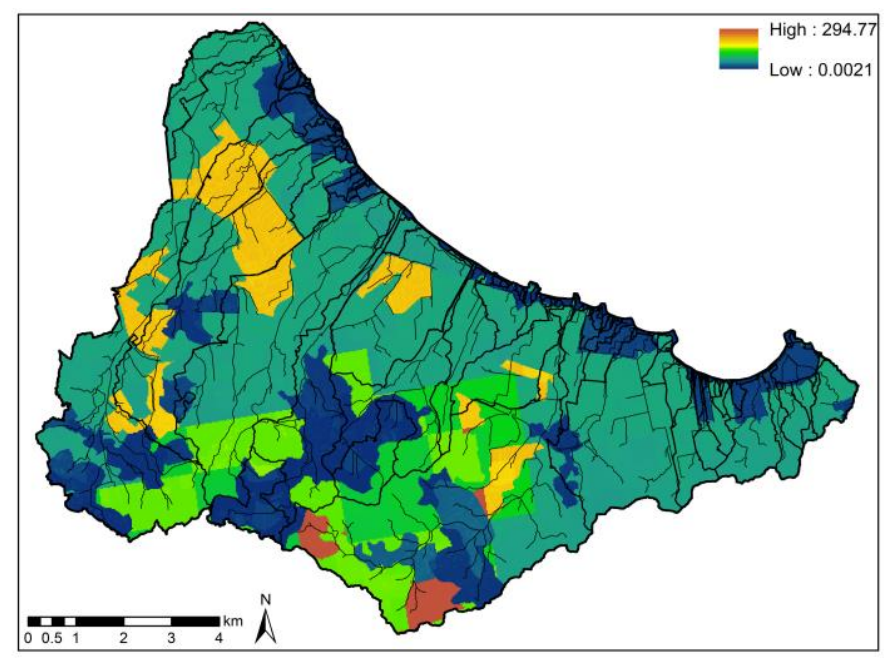

Figure 4-8 I Maximum static storage of the study area. Values in $\mathrm{mm}$.

The infiltration capacity at saturation (Figure 4-9) was calculated using the soil texture data, the organic matter content (Hiederer, 2013) and Saxton and Rawls (2006) pedotransfer functions. Percolation capacity (Figure 4-10) was estimated from the qualitative permeability map of the Instituto Geológico $y$ Minero de España (IGME). Due to the lack of sufficient information, the hydraulic conductivity of the interflow was the same as the saturated infiltration capacity (Francés et al., 2007). 
Exploring the possibilities of parsimonious nitrogen modelling in different ecosystems

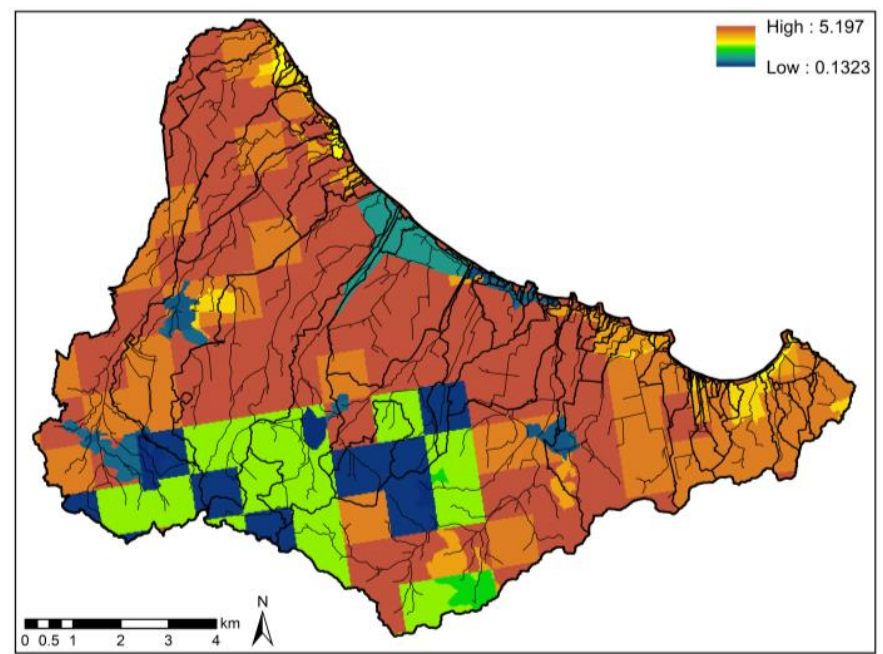

Figure 4-9 I Infiltration capacity at saturation of the study area. Values in $\mathrm{mm} \mathrm{h}^{-1}$.

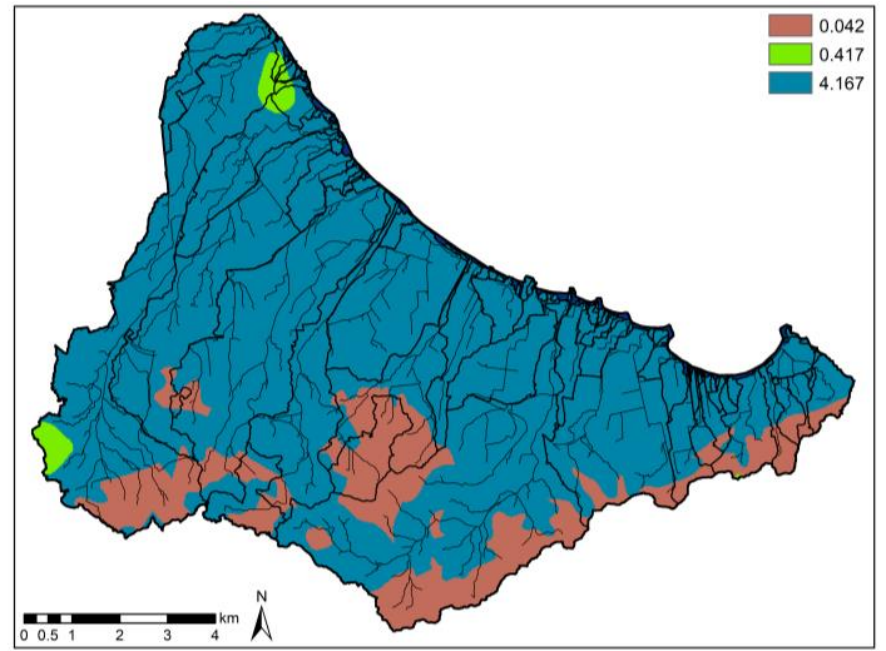

Figure 4-10 I Percolation capacity of the study area. Values in $\mathrm{mm} \mathrm{h}^{-1}$.

The sediment sub-model requires information about soil textural composition (Ballabio et al., 2016), which defines the particle size composition of the eroded parent material, and three USLE factors. The Kfactor (Figure 4-11) was calculated according to Panagos et al. (2014) from the soil texture data as:

$$
100 K=\left[\left(2.110^{-4} M^{1.14}(12-O M)+3.25(s-2)+2.5(p-3)\right) / 100\right] 1.317
$$


Exploring the possibilities of parsimonious nitrogen modelling in different ecosystems

where $K$ is the soil erodibility factor $\left(\mathrm{Mg} \mathrm{m}^{2} \mathrm{~h} \mathrm{ha}^{-1} \mathrm{hJ}^{-1} \mathrm{~cm}^{-1}\right), M$ is the textural factor, $O M$ is the organic matter content $(\%), s$ is the soil structure class and $p$ is the permeability class.

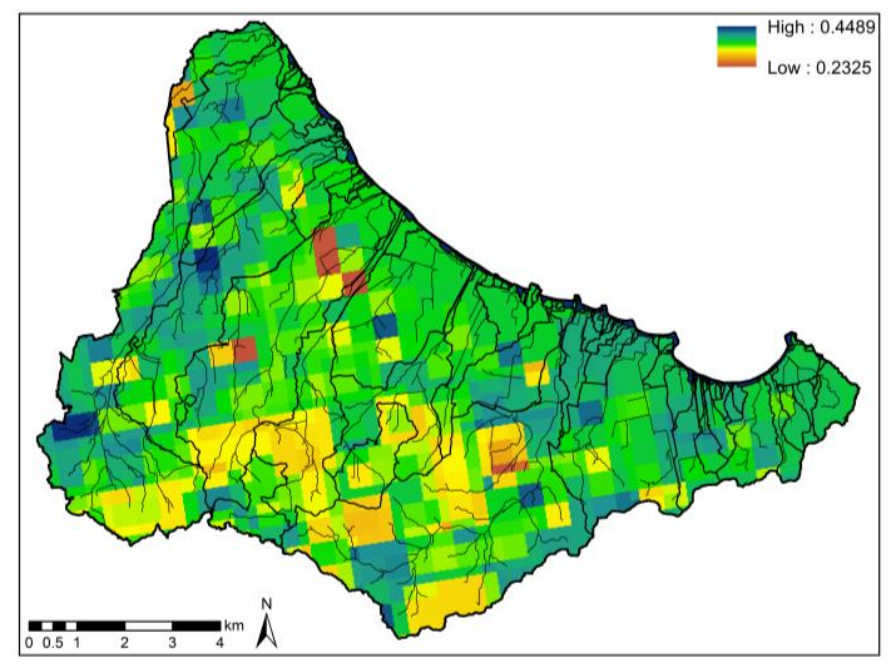

Figure 4-11 I K-factor values of the study area. Values in $\mathrm{Mg} \mathrm{m}^{2} \mathrm{~h} \mathrm{ha}^{-1} \mathrm{hJ}^{-1} \mathrm{~cm}^{-1}$.

The C-factor (Figure 4-12) was estimated according to the vegetation type using the values proposed by Alatorre et al. (2010) and the P-factor was set to 1 because support practices are not currently applied.

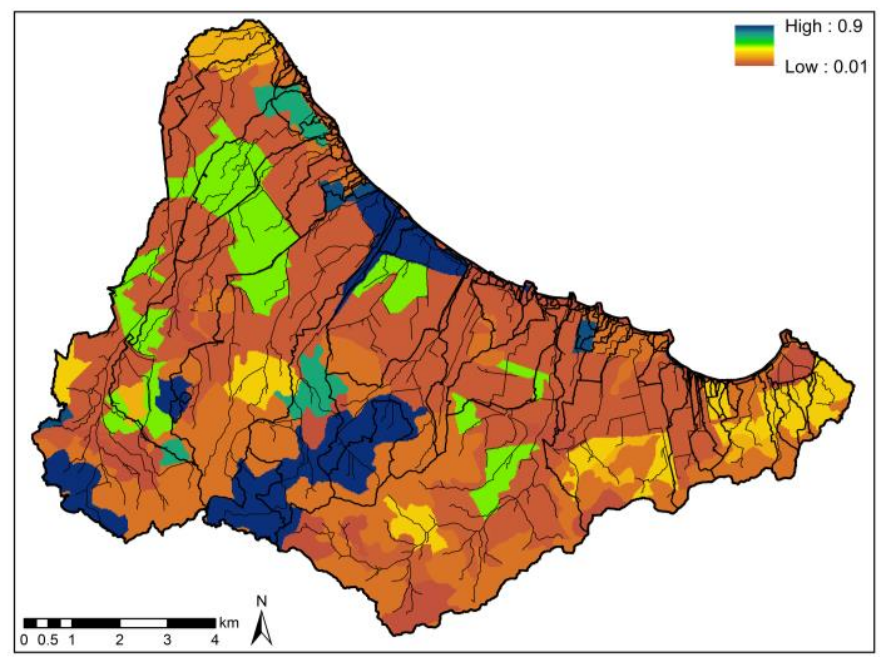

Figure 4-12 I C-factor values of the study area (dimensionless). 
Exploring the possibilities of parsimonious nitrogen modelling in different ecosystems

In the case of the nitrogen sub-model, the soil organic nitrogen map (Figure 4-13) was calculated from the soil organic carbon content map (Hiederer, 2013). This map was transformed to soil organic nitrogen content assuming typical soils' C:N ratios, 10 for agricultural land uses and 20 for the other land uses (Weil and Brady, 2017).

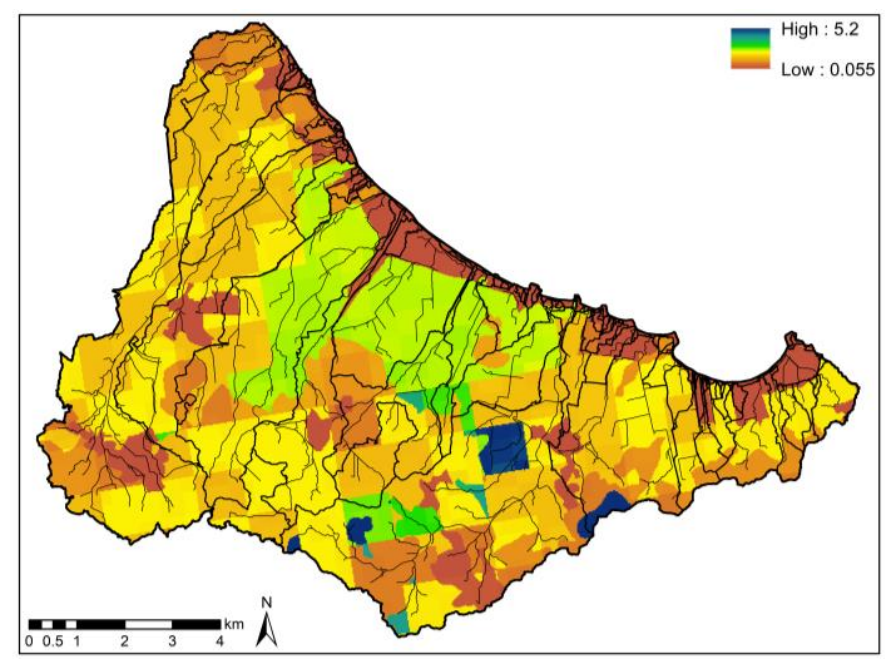

Figure 4-13 I Soil organic nitrogen content. Values in $\mathrm{kgN} \mathrm{m}^{-3}$.

The active soil depth was calculated as the minimum between the depth available to roots (Hiederer, 2013) and roots' depth, the bulk density map was obtained from Ballabio et al. (2016) and the previously calculated wilting point soil water content map was used. The $\mathrm{NH}_{4}{ }^{+}$distribution coefficient map was calculated as a function of the topsoil clay content map, while the seasonal variation of the vegetation cover factor for each land use was estimated according to the land use and aerial images.

Additionally, the crop growth sub-model requires crop-specific information. Plant date and harvest date were consulted with the water users association, while initial and final crop dry matter were estimated according to Gallardo et al. (2011), Rincon et al. (1999) and Suárez-Rey et al. (2016), for melon, broccoli and lettuce respectively. Initial and final crop cover factors were 
estimated by taking personal experience into account and the nitrogen preference form was estimated according to Albornoz and Lieth (2016) and Britto and Kronzucker (2013). Lastly, the base temperature and the cropspecific coefficients a and b were obtained from Rahn et al. (2010) and adjusted to the characteristics of the study area.

\subsubsection{Model inputs}

The model requires input information about climate, irrigation doses, fertilizer doses and nitrogen atmospheric deposition. Regarding precipitation and temperature, the $\mathrm{v} 4$ version of the SPAIN02 dataset (Herrera et al., 2016) was used. This dataset provides daily precipitation and temperature values from 1971 to 2008 and these series were extended until 2016 with the precipitation and temperature data provided by the Agencia Estatal de Meteorología (AEMET) of a near meteorological station placed in Cartagena. Due to the long simulated period and the lack of better data, evapotranspiration was calculated from the temperature values according to Hargreaves and Samani (1985). Irrigation areas and volumes were obtained from the Hydrological Watershed Plan of the Segura Region.

Concerning the fertilizer doses, only the land uses golf course (included in the urban fabric), citrus trees and horticultural crops were considered to be fertilized. The rainfed crop areas were excluded because being a semiarid area, the sowing depends on the precipitation amount and moreover, the area covered by rainfed crops is low, compared with the irrigated area (Table $4-1)$. The golf course fertilizer doses were obtained from consultation with experts in the field (Table 4-2 and Figure 4-14), while citrus doses were obtained from the monthly advisory fertilization program of the Sistema de Información Agraria de Murcia (SIAM), which establishes an annual fertilizer amount (Table 4-2) and its monthly distribution (Figure 4-14), values commonly respected by farmers. In both cases, these monthly fertilizer doses are homogenously transformed to daily values by the model, however, in 
Exploring the possibilities of parsimonious nitrogen modelling in different ecosystems case of the horticultural crops, as the fertilizer doses are more variable, values should be supplied daily to the model. The total fertilizer amounts were obtained from Ramos and Pomares (2010). These recommended values are not currently respected, hence, they were increased in order to take into account the excess and the $\mathrm{NO}_{3}$ - irrigation content. These final values were consulted with experts in the field and the water users association (Table 4-2). Total values were transformed to daily values according to the growing curve of each crop (Figure 4-14).
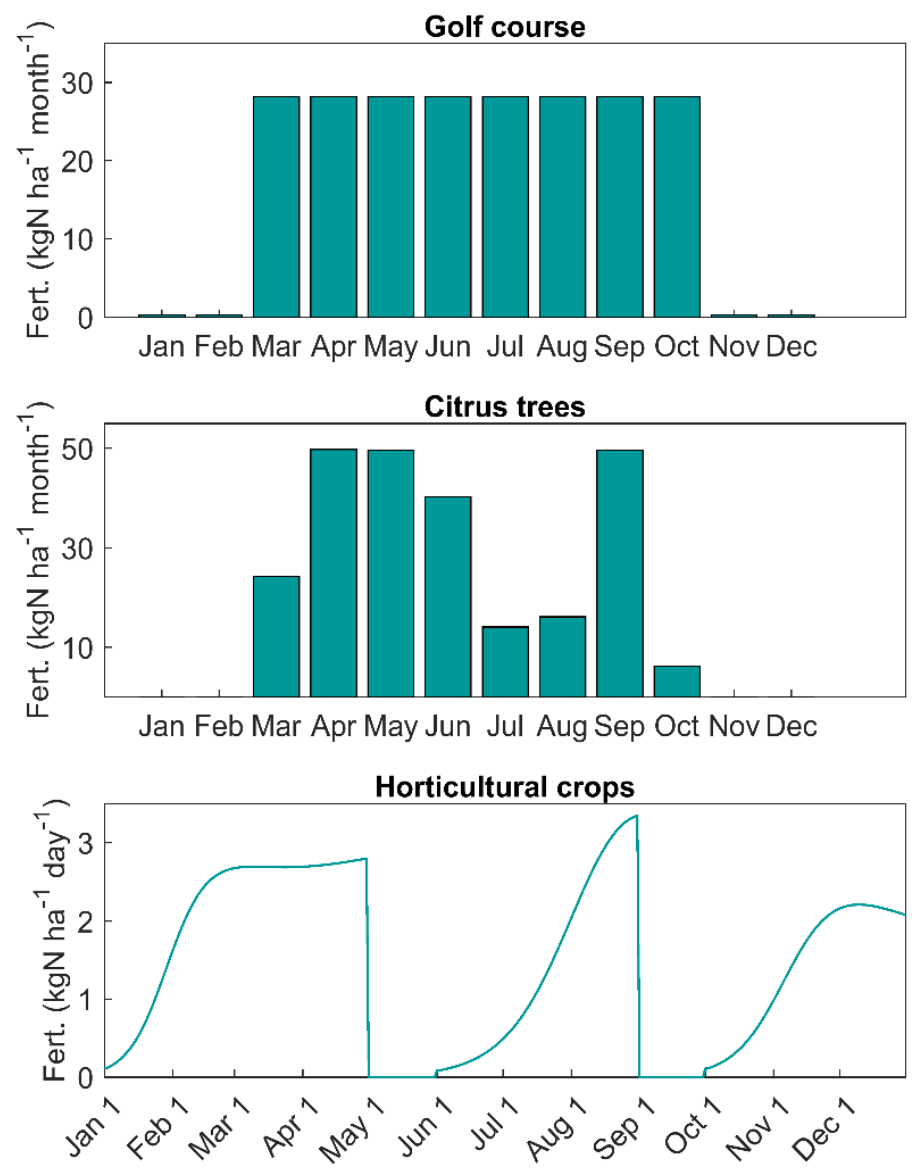

Figure 4-14 I Fertilizer doses. Golf course, citrus trees and horticultural crops land uses. 
Exploring the possibilities of parsimonious nitrogen modelling in different ecosystems

Table 4-2 I Current annual fertilizer doses. Values in $\mathrm{kgN} \mathrm{ha}^{-1}$ year $^{-1}$.

\begin{tabular}{llccc}
\hline \multicolumn{1}{c}{ Land use } & Fertilizer & Plant date & $\begin{array}{c}\text { Harvest } \\
\text { date }\end{array}$ \\
\hline Golf course & & 226 & - & - \\
Citrus trees & 250 & - & - \\
& Broccoli & 250 & Jan 1 & Apr 30 \\
Horticultural crops & Melon & 130 & Jun 1 & Aug 31 \\
& Lettuce & 130 & Oct 1 & Dec 31 \\
\hline
\end{tabular}

Finally, the atmospheric deposition values were obtained from GarcíaGómez et al. (2014). The total nitrogen atmospheric deposition in the study area is $7.5-10 \mathrm{kgN} \mathrm{ha}^{-1}$ year ${ }^{-1}$, with an approximate nitrate:ammonium ratio of 2:1. Therefore, the considered values for the study area were $3 \mathrm{kgN}-\mathrm{NH}_{4}{ }^{+}$ $\mathrm{ha}^{-1}$ year- $^{-1}$ and $6 \mathrm{kgN}^{-\mathrm{NO}_{3}}{ }^{-} \mathrm{ha}^{-1}$ year-1, which were homogenously transformed to daily values.

\subsection{Model implementation}

The model was calibrated in order to represent the current characteristics of the study area. Although it is evident that these have changed over the 46 years of data availability (1971-2016), these long input data series are used in order to obtain the model parameters, as well as, the water, sediments and nitrogen balances representative of the current situation of the study area.

Following the one-way nature of the model interactions (i.e., hydrologysediments-nitrogen), in a first step the calibration of the hydrological submodel was performed, then, the sediment sub-model was calibrated, and finally, the nitrogen sub-model. The model was calibrated using a daily time step and due to the lack of observed data, a common characteristic in arid and semiarid regions (Özcan et al., 2017a), the calibration was carried out in a non-traditional way.

In the case of the hydrological sub-model, as all the streams are ephemeral rivers, the interest remains in the surface runoff (overland flow and 
Exploring the possibilities of parsimonious nitrogen modelling in different ecosystems interflow) and percolation fluxes. Thus, due to the lack of groundwater information, only the hydrological correction factors governing these were calibrated. This calibration was based on previous flood studies (CAAMA, 2016a, 2016b) carried out by the Murcia Council (Consejería de Agua, Agricultura y Medio Ambiente de la Región de Murcia) in one of the sub-basins of the study area.

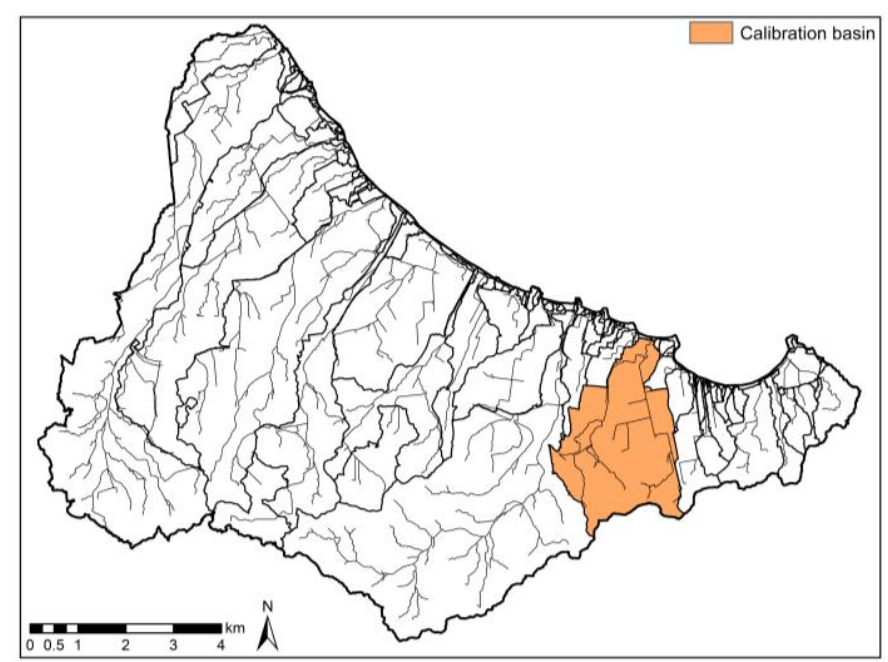

Figure 4-15 I Basin used to calibrate the hydrological and sediment sub-models.

From these flood studies, it was possible to calculate the 25-year return period outflow hydrograph of the larger basin in common (Figure 4-15), the volume of which was the data used to calibrate the sub-model. Calibration consisted in a chain of processes that were iteratively repeated in order to minimize the volume error between the simulated and calculated volumes. Hence, the model was run for the period 1971-2016 using the first year (1971) as a warm-up period and, with these results, a flood frequency analysis was performed to obtain the volume of the 25-year return period hydrograph. This value was compared to the calculated one. The 25-year return period was chosen because due to the length of the data series (46 years, 1971-2016), it was not possible to use a higher return period. 
Exploring the possibilities of parsimonious nitrogen modelling in different ecosystems

Likewise, no sediment measurements exist in this area and thus, the sediment sub-model calibration was performed using the same basin used to calibrate the hydrological sub-model (Figure 4-15) and based on the calculation of its mean annual erosion rate. This long-term annual erosion was calculated according to Wischmeier and Smith (1978):

$$
A=R K L S C P
$$

where $A$ is the mean annual erosion rate $\left(\mathrm{Mg} \mathrm{ha}^{-1}\right.$ year $\left.^{-1}\right), R$ is the rainfall and runoff factor $\left(\mathrm{hJ} \mathrm{cm} \mathrm{m}{ }^{-2} \mathrm{~h}^{-1}\right.$ year $\left.^{-1}\right), K$ is the soil erodibility factor $\left(\mathrm{Mg} \mathrm{m}^{2} \mathrm{~h}\right.$ ha$\left.{ }^{1} \mathrm{hJ}^{-1} \mathrm{~cm}^{-1}\right), L S$ is the topographical factor, $C$ is the cover-management factor and $P$ the support practice factor. The $\mathrm{K}, \mathrm{C}$ and $\mathrm{P}$ factors were calculated from the input model maps. The $\mathrm{R}$ factor was obtained from the $\mathrm{R}$ isoline map of the Spanish Instituto para la Conservación de la Naturaleza (ICONA) and the LS factor was obtained from Mintegui et al. (1993), which established a relation between this factor and the slope for the Mediterranean region. Then, the sediment sub-model correction factors were calibrated to minimize the volume error between simulated and calculated mean annual erosion rates. In the case of sediments, the sub-model is markedly influenced by the initial condition (Bussi et al., 2014), and consequently, with the aim of obtaining a representative initial condition, the model was firstly run for the period 1971-2016, which was a long enough period, and the obtained final condition was then used as initial condition for the calibration period (19712016). From these results, the mean annual erosion rate was obtained and this value was compared to the calculated one.

With both sub-models calibrated, the last step was to calibrate the nitrogen sub-model. In this case, since the sub-model presents specific parameters for each land use, all the study area was used during the calibration process. Instream nitrogen parameters were all fixed to cero because the residence time is lower than a day, and as no nitrogen measurements or nitrogen-related information exists for this area, the land use parameters were adjusted to 
Exploring the possibilities of parsimonious nitrogen modelling in different ecosystems accomplish the nitrogen plant potential uptake of each land use. The initial values for the land use specific parameters were obtained from literature (D'Odorico et al., 2003; Jung et al., 2010; Kimmins, 2004; Rankinen et al., 2006; Wade et al., 2002; Weil and Brady, 2017). The calibration process consisted in adjusting these values to obtain a mean annual uptake for the period 20022011 similar to the annual plant potential uptake. Then, the parameters values were validated during the period 2012-2016, and specifically the horticultural crops parameters, which represent the largest and more interesting area, were validated comparing the estimated crop yield target (Gallardo et al., 2011; Rincon et al., 1999; Suárez-Rey et al., 2016) and the simulated crop yield during the period 2002-2016. The period 1971-2001 was used as a warm-up period to obtain the initial condition.

Validation was carried out only for the hydrological results, which are related to all sub-models. In agricultural areas, evapotranspiration is a very important state variable and hence, the evapotranspiration results from 2013 to 2016 were compared to the v3.3b satellite data of the Global Land Evaporation Amsterdam Model (GLEAM) (Martens et al., 2017; Miralles et al., 2011). Nevertheless, even if the prediction power of the model is not high, it can be used to evaluate the effectiveness of different management practices (Özcan et al., 2017a), because this process is based on comparisons and model simulations are used herein as projections of ecosystem behaviour rather than predictions.

Finally, in order to obtain the long-term annual balances that characterize the baseline scenario (current situation), the model inputs were extended assuming climate repetition. Therefore, the calibrated model was run for the period 2002-2016 and, again, for the period 1971-2016 (61 years). From these results, the mean annual balances, representative of the current situation, were obtained. 


\subsection{Best management practices scenarios and model representation}

Several management practices were evaluated with the aim of helping decision makers to develop an appropriate management strategy at the watershed scale. To analyse the results, the changes in the amount of pollutants (i.e., nitrogen and sediments) were compared with the baseline scenario, which represents the current practices carry out in the study area. Effectiveness of each scenario was computed as the percent change:

$$
\text { Percent change }=\frac{B M P-\text { baseline }}{\text { baseline }} 100
$$

where Percent change is the percent change (\%), BMP is the average annual pollutants load of each management practice scenario and baseline is the average annual pollutants load of the baseline scenario.

The management practices established in the official regulations of 2017 and 2018 (CARM, 2018, 2017) were chosen to be evaluated and, additionally, less and more restrictive variations were also included as additional scenarios (additional). According to Pearce and Yates (2017) and Wang et al. (2018) the management practices can be divided into structural and non-structural. Structural practices are based on the installation of facilities whose aim is to intercept pollutants (e.g., filter strips, strip cropping or contour farming) while non-structural practices are based on the application of agricultural management methods whose aim is to reduce pollution (e.g., fertilizer management, irrigation management or no tillage). In this study, both structural and non-structural management practices were evaluated: contour farming (additional), contour farming and grassy field borders (additional), contour farming and hedgerow field borders (CARM, 2018, 2017), $100 \mathrm{~m}$ coastal line buffer (CARM, 2018, 2017), $500 \mathrm{~m}$ coastal line buffer (additional), fertilizer management with the traditional three-crop rotation 
Exploring the possibilities of parsimonious nitrogen modelling in different ecosystems (CARM, 2017) and fertilizer management with two-crop rotation (CARM, 2018).

These scenarios were simulated using the same initial conditions as in the baseline scenario and for the same period 2002-2016-1971-2016 (61 years). The management practices were considered to affect citrus trees and horticultural crops land uses, and their results were evaluated in terms of nitrogen loss (surface nitrogen export, which correspond to the dissolved and sorbed nitrogen transported by the overland flow and interflow, and nitrogen leaching), sediment yield and crop yield. The model is not able to simulate crop yield in the case of fruit trees and thus, crop yield was only evaluated in the area covered by horticultural crops.

\subsubsection{Contour farming}

Contour farming (CF) practice is a farming technic in which field operations (i.e., plowing, planting or sowing, cultivating and harvesting) are performed following field contours around the slope. This technic is commonly used because it prevents soil erosion, especially under storm events, and as agricultural soils present high nitrogen contents, reducing soil erosion can also reduce nitrogen transport.

This effect was introduced to the model by modifying the P-factor map of the sediment sub-model. The value of the P-factor in the agricultural areas with non-woody crops (i.e., horticultural crops) was calculated according to Panagos et al. (2015) as:

$$
P=P_{c} P_{s w} P_{v m}
$$

where $P$ is the support practice factor, $P_{c}$ is the contouring sub-factor, $P_{s w}$ is the stone walls sedimentation sub-factor (i.e., terrace sub-factor) and $P_{v m}$ is the vegetated margins sub-factor. Hence, as the slope in these areas is 3-8\%, according to Wischmeier and Smith (1978), the $P_{c}$ sub-factor took a value of 
Exploring the possibilities of parsimonious nitrogen modelling in different ecosystems

0.5 , while the other sub-factors were set to 1 because no terraces and no vegetated margins were considered in this scenario (Table 4-3).

Table 4-3 I Final $\mathrm{P}$-factor and $\mathrm{P}_{\mathrm{c}}, \mathrm{P}_{\mathrm{sw}}$ and $\mathrm{P}_{\mathrm{vm}}$ sub-factors values in the horticultural crops land use. $\mathrm{CF}$ is contour farming, $\mathrm{CF}+\mathrm{GFB}$ is contour farming and grassy field borders and $\mathrm{CF}+\mathrm{HFB}$ is contour farming and hedgerow field borders.

\begin{tabular}{lcccc}
\hline \multicolumn{1}{c}{ Scenario } & $\mathbf{P}_{\mathbf{c}}$ & $\mathbf{P}_{\mathrm{sw}}$ & $\mathbf{P}_{\mathrm{vm}}$ & $\mathbf{P}$ \\
\hline Baseline & 1 & 1 & 1 & 1 \\
CF & 0.5 & 1 & 1 & 0.5 \\
CF+GFB & 0.5 & 1 & 0.66 & 0.33 \\
CF+HFB & 0.5 & 1 & 0.09 & 0.045 \\
\hline
\end{tabular}

\subsubsection{Contour farming and grassy field borders}

This combination of management practices ( $\mathrm{CF}+\mathrm{GFB})$ consists in carrying out contour farming and the installation of grassy field borders along the perimeter of the fields. These grassy field borders are defined as linear areas consisting of herbaceous perennial species (non-woody species) and their installation reduces flow velocity and consequently, soil erosion, as well as, sediment and nutrient transport as they are trapped when reaching the edgeof-the-field vegetated margin.

As in the case of $\mathrm{CF}$, this effect was introduced to the model by modifying the P-factor map of the sediment sub-model in the agricultural areas with non-woody crops (i.e., horticultural crops) according to Panagos et al. (2015). The $P_{c}$ sub-factor took the same value and the $P_{s w}$ sub-factor was set to 1 because no terraces were considered (Table 4-3). According to Panagos et al. (2015) the value of the $P_{v m}$ sub-factor for grass borders takes a value of 0.66 and according to Van Vooren et al. (2017), sediment interception is 55\% for a grass border of $2 \mathrm{~m}$ width, which corresponds to a $P_{\mathrm{vm}}$ of 0.45 . In order to not overestimate its effectiveness, the 0.66 value with a common grass border of $2 \mathrm{~m}$ width was adopted (Table 4-3).

The area covered by the grassy borders, which corresponds to a decrease of crop yields, was calculated according to the borders length estimated by Rey 
Exploring the possibilities of parsimonious nitrogen modelling in different ecosystems

Benayas et al. (2017). In this study, 4 different placement priorities are established being priorities 1, 2 and 4 the ones established in CARM (2018, 2017) proposal, hence a total borders length of $393.549 \mathrm{~m}$ and $2 \mathrm{~m}$ width was considered.

\subsubsection{Contour farming and hedgerow field borders}

This second combination of management practices $(\mathrm{CF}+\mathrm{HFB})$ consists in carrying out contour farming and the installation of hedgerow field borders along the perimeter of the fields. These hedgerow field borders are defined as perennial woody and non-woody structures consisting of herbaceous species, shrubs and trees that reduce flow velocity and sediment and nutrient transport.

Likewise, this effect was introduced to the model by modifying the P-factor map of the sediment sub-model according to Panagos et al. (2015) in the agricultural areas with non-woody crops (i.e., horticultural crops). The $\mathrm{P}_{\mathrm{c}}$ and $\mathrm{P}_{\mathrm{sw}}$ sub-factors took the same values (Table 4-3) and according to Van Vooren et al. (2017), sediment interception is estimated in $91 \%$, not being the hedgerow width an explanatory variable. Therefore, the $P_{v m}$ sub-factor took a value of 0.09 (Table 4-3) and, as estimated by Rey Benayas et al. (2017) and proposed by CARM $(2018,2017)$, a total borders length of $393.549 \mathrm{~m}$ and 2.5 $\mathrm{m}$ width was considered.

\subsubsection{Coastal line buffer}

These scenarios consist in removing the agricultural non-woody crops in a $100 \mathrm{~m}$ (CB100) and $500 \mathrm{~m}$ (CB500) coastal line buffers. In the long-term, this abandoned land will overgrow with herbaceous vegetation and scarce shrubs (i.e., natural grasslands). Due to the removal of crops, these areas remain unfertilized and thus, nutrient transport is reduced in the most vulnerable area, the coast. The CB100 scenario only affected $0.08 \mathrm{~km}^{2}$ while 
the CB500 scenario affected $1.53 \mathrm{~km}^{2}$ (Figure 4-16), since the coast is highly urbanized in this area.

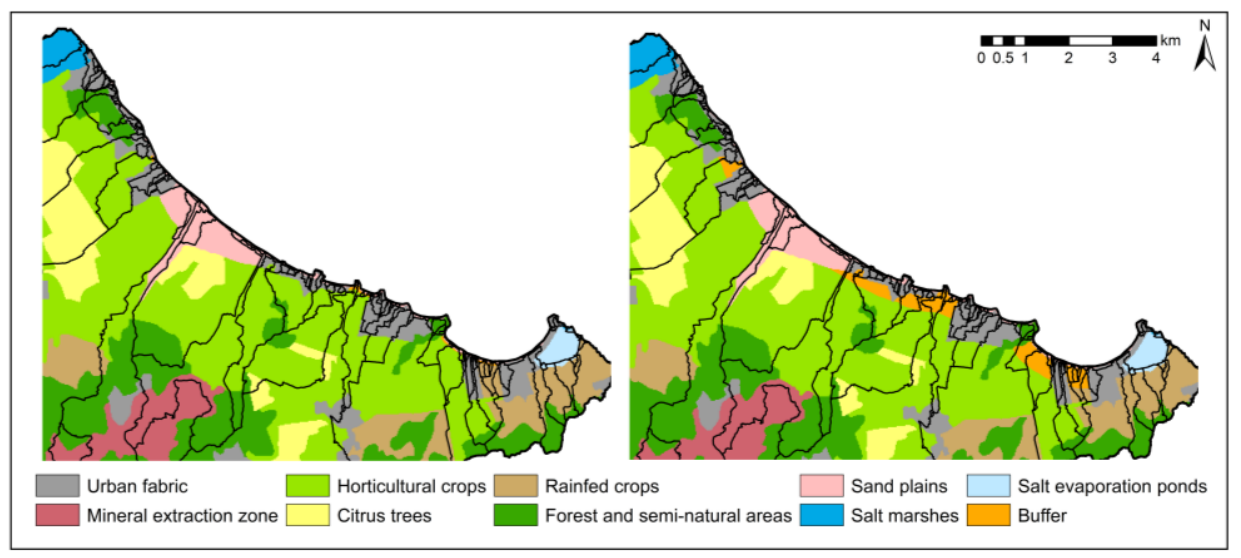

Figure 4-16 I Land use maps of the CB100 and CB500 scenarios (Corine Land Cover 2006). Zoom to the coastal line

These two management practices scenarios were introduced to the model as a land use change (Figure 4-16) by modifying the parameters that depend on land uses, and obviously, the land use map. Hydrology related changes affected the maximum static storage because root's depth changed, the monthly value of the crop coefficient and irrigation, because these areas stopped being irrigated. Regarding the sediment parameters, only the Cfactor, which depends on land uses, was affected, and in the case of the nitrogen parameters, the active soil depth. The nitrogen land use specific parameters for this new land use were calibrated as explained in section 4.5 Model implementation.

\subsubsection{Fertilizer management}

Fertilizer management (FM) consist in reducing the nitrogen excess by controlling the application timing and fertilizer dose in a rational way. Timing is usually an important factor because a frequent application of a small amount entails that less nitrogen would be available for leaching and hence, more for crop uptake. However, fertigation in the study area is 
Exploring the possibilities of parsimonious nitrogen modelling in different ecosystems already daily and as the model time step is also daily, this is already the best option. Concerning the fertilizer doses, instead of reducing the fertilizer amount by a fixed percentage, the reduction was based on a simple soil-plant nitrogen mass balance, which affected citrus and horticultural land uses. This mass balance was applied as stated in the official regulation of 2017 (CARM, 2017) and the fertilizer doses were calculated as:

$$
\text { Fert }=D_{\text {max }}-N_{\text {ini }}-N_{\text {min }}-N_{\text {org }}-N_{\text {irr }}
$$

where Fert is the total inorganic fertilizer amount $\left(\mathrm{kgN} \mathrm{ha}^{-1}\right), D_{\max }$ is the maximum recommended fertilizer dose for a specific crop $\left(\mathrm{kgN} \mathrm{ha}^{-1}\right), N_{\text {ini }}$ is the mineral nitrogen soil content before planting $\left(\mathrm{kgN} \mathrm{ha}^{-1}\right), N_{\min }$ is the nitrogen which results from the organic matter mineralization process between plant and harvest $\left(\mathrm{kgN} \mathrm{ha}^{-1}\right), N_{\text {org }}$ is the organic fertilizer $\left(\mathrm{kgN} \mathrm{ha}^{-1}\right)$ and $N_{i r r}$ is the nitrogen amount present in the irrigation water $\left(\mathrm{kgN} \mathrm{ha}^{-1}\right)$.

Table 4-4 I Nitrogen mass balance for each crop and scenario. Values expressed in $\mathrm{kgN} \mathrm{ha}^{-1}$ year $^{-1}$. FM is fertilizer management and $\mathrm{FM}+\mathrm{CR}$ is fertilizer management and two-crop rotation.

\begin{tabular}{cllcccccc}
\cline { 2 - 8 } Land use & D & Naxi & N $_{\text {min }}$ & Fert & $\begin{array}{c}\text { Plant } \\
\text { date }\end{array}$ & $\begin{array}{c}\text { Harvest } \\
\text { date }\end{array}$ \\
\hline \multirow{2}{*}{ FM } & Citrus trees & & 250 & 0.9 & 11.8 & 238 & - & - \\
scenario & Horticultural & Broccoli & 218 & 19.8 & 8.2 & 191 & Jan 1 & Apr 30 \\
& crops & Melon & 118 & 20.1 & 1.1 & 97 & Jun 1 & Aug 16 \\
& Lettuce & 126 & 17.7 & 0.2 & 109 & Oct 1 & Dec 16 \\
\hline \multirow{2}{*}{ FM+CR } & Citrus trees & & 250 & 0.9 & 11.8 & 238 & - & - \\
\multirow{2}{*}{ scenario } & \multirow{2}{*}{ Horticultural } & Broccoli & 218 & 22.8 & 8.2 & 187 & Jan 1 & Apr 30 \\
& crops & Melon & - & - & - & - & - & - \\
& & Lettuce & 126 & 21.1 & 0.2 & 105 & Oct 1 & Dec 16 \\
\hline
\end{tabular}

In this case, $\mathrm{N}_{\text {org }}$ took a cero value because no organic fertilizer is used in the study area and both crop products and residues are removed from fields. $\mathrm{N}_{\text {irr }}$ was considered to be included in the term FERT because it is difficult to know the nitrogen content of the irrigation water, therefore, the fertilizer amount calculated herein includes the nitrogen content of the irrigation water, which the farmers should discount by means of simple water analysis 
at field scale. $D_{\max }$ was calculated according to CARM (2017), while $\mathrm{N}_{\min }$, due to the lack of data, was calculated as the average value of the organic matter mineralization between plant and harvest for each crop using the results of the baseline scenario simulation. Nini was calculated in the same way, but this value was corrected by a depletion coefficient as estated in CARM (2017), which took a value of $14 \%$ in the case of horticultural crops and $10 \%$ in the case of citrus trees. Moreover, CARM (2017) establishes a 3-months crop exclusion period, and thus, the plant and harvest dates of the melon and lettuce were adjusted because it is possible to change to shorter varieties. These final values are listed in Table $4-4$ and the total fertilizer reduction with respect to the baseline scenario in Table 4-5.

Table 4-5 I Annual fertilizer doses for each crop and scenario. Fertilizer values expressed in $\mathrm{kgN} \mathrm{ha-1}$ year-1 $^{-1} \mathrm{FM}$ is fertilizer management and $\mathrm{FM}+\mathrm{CR}$ is fertilizer management and twocrop rotation.

\begin{tabular}{llccccc}
\hline \multirow{2}{*}{ Land use } & \multicolumn{2}{c}{$\begin{array}{l}\text { Baseline } \\
\text { scenario }\end{array}$} & \multicolumn{2}{c}{ FM scenario } & \multicolumn{2}{c}{ FM+CR scenario } \\
\cline { 2 - 7 } & & Fertilizer & Fertilizer & \% Reduc. & Fertilizer & \% Reduc. \\
\hline Citrus trees & 250 & 238 & 4.8 & 238 & 4.8 \\
\multirow{2}{*}{ Horticultural } & Broccoli & 250 & 191 & 23.6 & 187 & 25.2 \\
crops & Melon & 130 & 97 & 25.4 & - & 100.0 \\
& Lettuce & 130 & 109 & 16.2 & 105 & 19.2 \\
\hline
\end{tabular}

\subsubsection{Fertilizer management and two-crop rotation}

This combination $(\mathrm{FM}+\mathrm{CR})$ consist in reducing the nitrogen excess by controlling the fertilizer doses and by changing the productive cultivation system from a three-crop rotation to a two-crop rotation, as established in the official regulation of 2018 (CARM, 2018). This new official regulation modifies the latter in that only two crops can be cultivated during the same year, because it is expected that if less crops are cultivated, the fertilizer amount is reduced, and consequently, the nitrogen surplus.

As in the FM scenario, the fertilizer doses were adjusted according to CARM (2018) and, additionally, the melon was selected to not be cultivated because 
Exploring the possibilities of parsimonious nitrogen modelling in different ecosystems

it is the crop with a more variable market price. Likewise, $D_{\max }$ was calculated according to CARM (2018), $\mathrm{N}_{\min }$ was calculated as an average value for each crop from the results of the model simulation in the current situation but excluding the melon from the simulation and $\mathrm{N}_{\text {ini }}$ was calculated in the same way, but this value was corrected by the corresponding depletion coefficient (CARM, 2018). The obtained values are listed in Table 4-4 and the total fertilizer reduction with respect to the baseline scenario in Table 4-5.

\subsection{Results and discussion}

\subsubsection{Model implementation: baseline scenario}

Regarding the hydrological implementation, Figure 4-17 shows the results of the flood frequency analysis, in which a Two-Component Extreme Value (TCEV) distribution was used. The fitting between the annual maximum volumes simulated by TETIS for the calibration basin (Figure 4-15) and the TCEV distribution was satisfactory and the volume error (Table 4-6) between the simulated and calculated volume of the 25-year return period hydrograph was lower than $0.5 \%$ (absolute value).

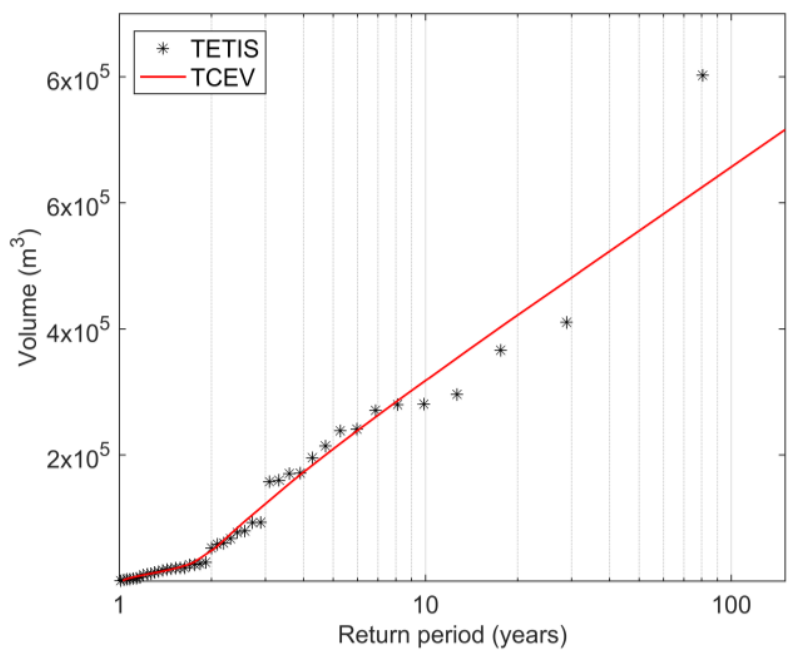

Figure 4-17 I Flood frequency analysis results. 
Exploring the possibilities of parsimonious nitrogen modelling in different ecosystems

Table 4-6 I Calculated and simulated volume of the 25-year return period hydrograph.

\begin{tabular}{lc}
\hline Flood study (calculated; CAAMA, 2016a, 2016b) & $457000 \mathrm{~m}^{3}$ \\
TETIS-N (simulated) & $455016 \mathrm{~m}^{3}$ \\
\hline Volume error & $-0.43 \%$ \\
\hline
\end{tabular}

The performance of the model in reproducing total evapotranspiration from 2003 to 2016 was satisfactory, with a $\mathrm{R}^{2}$ value of 0.51 and showing a good agreement between observed satellite data and simulated (Figure 4-18).

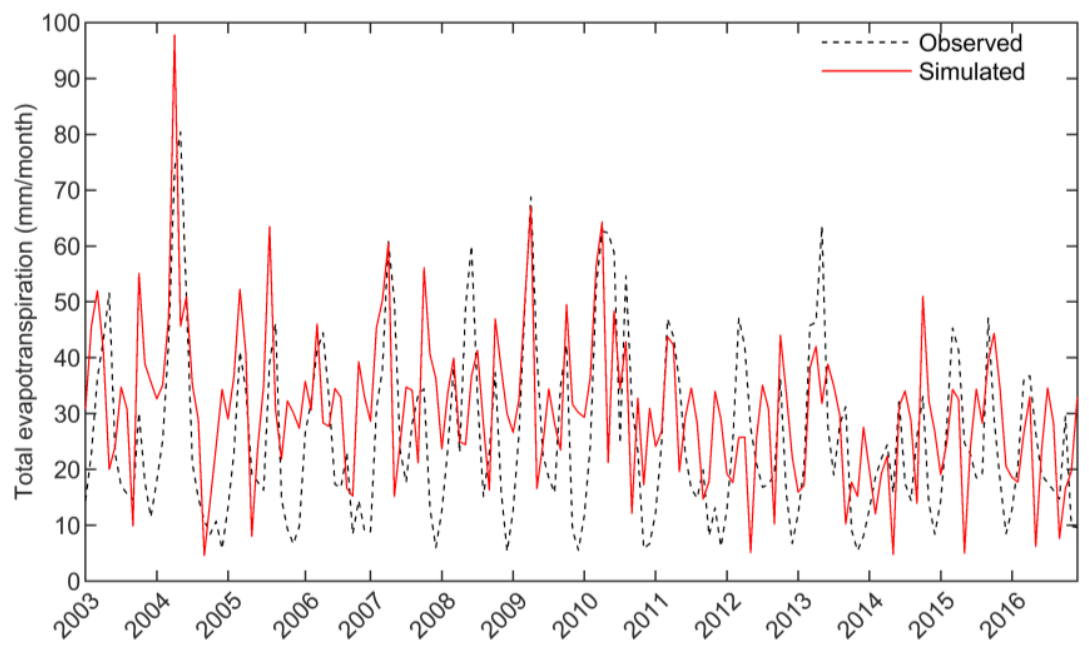

Figure 4-18 I Observed and simulated monthly total evapotranspiration.

In the case of the sediment sub-model calibration, Table 4-7 shows the calculated long-term annual erosion rate and the value of each USLE factor for the basin used in the calibration process (Figure 4-15). The volume error between calculated and simulated mean annual erosion (Table 4-8) was also lower than $0.5 \%$ (absolute value).

Table 4-7 I Calculated mean annual erosion rate and values of the USLE factors.

\begin{tabular}{lc}
\hline $\mathbf{A}$ & $9.29 \mathrm{Mg} \mathrm{ha}^{-1}$ year-1 $^{-1}$ \\
\hline $\mathbf{R}$ & $100 \mathrm{hJ} \mathrm{cm} \mathrm{m}^{-2} \mathrm{~h}^{-1}$ year-1 $^{-1}$ \\
$\mathbf{K}$ & $0.38 \mathrm{Mg} \mathrm{m}^{2} \mathrm{~h} \mathrm{ha}^{-1} \mathrm{hJ}^{-1} \mathrm{~cm}^{-1}$ \\
$\mathbf{L S}$ & 2.45 \\
$\mathbf{C}$ & 0.10 \\
$\mathbf{P}$ & 1 \\
\hline
\end{tabular}


Exploring the possibilities of parsimonious nitrogen modelling in different ecosystems

Table 4-8 I Calculated and simulated mean annual erosion rate.

\begin{tabular}{lc}
\hline USLE (calculated) & $9.29 \mathrm{Mg} \mathrm{ha}^{-1}$ year-1 $^{-1}$ \\
TETIS-N (simulated) & $9.27 \mathrm{Mg} \mathrm{ha}^{-1}$ year $^{-1}$ \\
\hline Volume error & $-0.22 \%$ \\
\hline
\end{tabular}

The results of the nitrogen sub-model implementation are shown in Table 4-9 and Table 4-10. In general, the simulated mean annual nitrogen uptake, during both calibration and validation periods, presented low volume errors and only the land uses mineral extraction zone and rainfed crops obtained higher differences between estimated and simulated uptakes. In the case of the mineral extraction zone land use, the model was not able to reduce the nitrogen uptake, however, although the obtained volume errors during both, calibration and validation periods, were high, these differences are lower than $1.5 \mathrm{kgN} \mathrm{ha}^{-1}$ year-1, which is a tolerable difference. Moreover, the elevated volume errors obtained in the case of the rainfed crops land use are because this area remains unfertilized for modelling purposes. Hence, the results obtained in terms of plant nitrogen uptake were considered satisfactory. Additionally, the difference between the estimated crop yield targets (Gallardo et al., 2011; Rincon et al., 1999; Suárez-Rey et al., 2016) and the simulated crop yields was acceptable (Table 4-10), with volume errors lower than $10 \%$ (absolute value).

Table 4-9 I Estimated and simulated mean annual potential nitrogen uptake for the simplified land uses. Values in parenthesis represent volume error. Values expressed in $\mathrm{kgN} \mathrm{ha}^{-1}$ year $^{-1}$.

\begin{tabular}{lccccc}
\hline \multicolumn{1}{c}{ Land use } & $\begin{array}{c}\text { Estimated } \\
\text { uptake }\end{array}$ & \multicolumn{2}{c}{$\begin{array}{c}\text { Calibration } \\
\text { (2002-2011) }\end{array}$} & \multicolumn{2}{c}{$\begin{array}{c}\text { Validation } \\
(\mathbf{2 0 1 2}-2016)\end{array}$} \\
\hline $\begin{array}{l}\text { Urban fabric (includes golf } \\
\text { course) }\end{array}$ & 47.4 & 47.2 & $(-0.3 \%)$ & 47.7 & $(+0.5 \%)$ \\
Mineral extraction zone & 3.0 & 4.2 & $(+40.0 \%)$ & 4.4 & $(+46.7 \%)$ \\
Horticultural crops & 460.0 & 455.2 & $(-1.0 \%)$ & 462.4 & $(+0.5 \%)$ \\
Citrus trees & 250.0 & 276.5 & $(+10.6 \%)$ & 273.4 & $(+9.4 \%)$ \\
Rainfed crops & 60.8 & 30.9 & $(-49.1 \%)$ & 22.3 & $(-63.3 \%)$ \\
Forest and semi-natural areas & 21.4 & 20.5 & $(-4.3 \%)$ & 18.3 & $(-14.5 \%)$ \\
Sand plains & 0.0 & 0.0 & $(0.0 \%)$ & 0.0 & $(0.0 \%)$ \\
Salt marshes & 10.0 & 11.5 & $(+15.2 \%)$ & 11.3 & $(+13.0 \%)$ \\
\hline
\end{tabular}


Exploring the possibilities of parsimonious nitrogen modelling in different ecosystems

Table 4-10 I Estimated crop yield target and simulated crop yield (dry matter). Values in parenthesis represent volume error. Values are expressed in $\mathrm{Mg} \mathrm{ha}^{-1}$ year-1. $^{-1}$

\begin{tabular}{lccc}
\hline \multicolumn{1}{c}{ Crop } & $\begin{array}{c}\text { Estimated } \\
\text { yield }\end{array}$ & \multicolumn{2}{c}{$\begin{array}{c}\text { Validation } \\
\text { (2002-2016) }\end{array}$} \\
\hline Broccoli & 8.7 & 7.9 & $(-8.6 \%)$ \\
Melon & 1.0 & 1.0 & $(-4.9 \%)$ \\
Lettuce & 3.3 & 3.1 & $(-5.5 \%)$ \\
\hline
\end{tabular}

Finally, the baseline scenario long-term mean annual balances (61 years) are shown in Table 4-11. With regard to the water balance, almost all the water input (precipitation and irrigation) is evapotranspirated and the remaining volume is split into surface runoff and percolation. The mean annual erosion rate obtained is quite high and according to Albaladejo Montoro et al. (1988) it corresponds to a moderate-high erosion rate, although it is in the range of previous studies developed in southeast Spain (Boix-Fayos et al., 2005; Sougnez et al., 2011). Nevertheless, despite this elevated erosion, almost all the eroded sediments are deposited, being sediment yield much lower. The area with higher erosion rates is the mineral extraction zone, which is a very degraded area with sparse vegetation and bare soil, but the agricultural area still presents a mean annual erosion rate of $2.6 \mathrm{Mg} \mathrm{ha}^{-1}$, which is interesting to reduce because agricultural soils present high contents in organic matter and nutrients (García-Ruiz et al., 2015; Merchán et al., 2018).

With respect to the nitrogen balance, the main nitrogen input is the fertilizer addition and the main nitrogen output is the plant nitrogen uptake which is slightly lower. This nitrogen surplus is removed from the soil due to surface runoff and percolation fluxes during high precipitation events and, although the obtained surface water runoff and percolation flows are similar (33-34 $\mathrm{mm})$, the difference between surface nitrogen export $\left(1.7 \mathrm{kgN} \mathrm{ha}^{-1}\right.$ year $\left.^{-1}\right)$ and nitrogen leaching (11.8 $\mathrm{kgN} \mathrm{ha}^{-1}$ year $\left.{ }^{-1}\right)$ is elevated. Nonetheless, it is a common situation in intensive agriculture (Pärn et al., 2012; Randall and Mulla, 2001) and in this case the higher nitrogen values are obtained in the agricultural areas (Figure 4-19). Moreover, it should be highlighted that 
Exploring the possibilities of parsimonious nitrogen modelling in different ecosystems García-Pintado et al. (2007) obtained a similar value in the case of total nitrogen export, estimated at $171 \mathrm{MgN}_{\text {year }}{ }^{-1}$ for the whole watershed, which considering a total area of $1200 \mathrm{~km}^{2}$ corresponds to $1.4 \mathrm{kgN} \mathrm{ha}^{-1}$ year-1. $^{-1}$.

Table 4-11 I Baseline scenario long-term mean annual balances on the soil.

\begin{tabular}{lc}
\hline \multicolumn{2}{c}{ Water balance $\mathbf{( m m )}$} \\
\hline Precipitation & 280.9 \\
Irrigation & 178.9 \\
Evapotranspiration & 392.6 \\
Percolation & 34.2 \\
Surface runoff & 32.9 \\
\hline \multicolumn{2}{c}{ Sediment balance $\mathbf{( \mathbf { M g ~ h a } ^ { - 1 } )}$} \\
\hline Erosion Nitrogen balance (kgN ha-1) \\
Deposition & 37.2 \\
Sediment yield & 30.8 \\
\hline \multicolumn{2}{c}{$\quad$} \\
\hline Fertilizer addition & 206.8 \\
Atmospheric deposition & 9.1 \\
Net mineralization & 17.3 \\
Plant nitrogen uptake & 220. \\
Nitrogen leaching & 11.8 \\
Surface nitrogen export & 1.7 \\
\hline
\end{tabular}

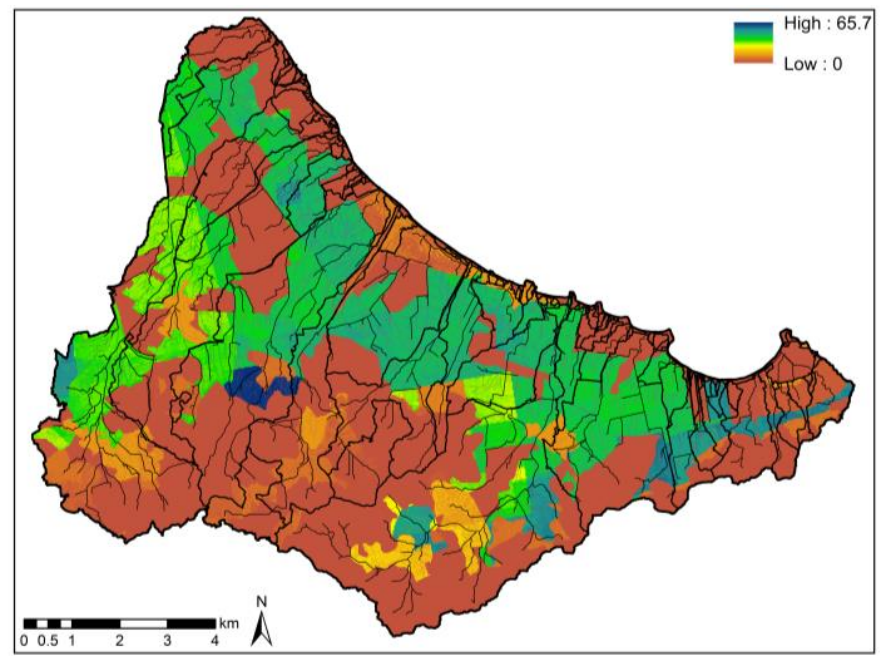

Figure 4-19 I Total nitrogen leaching for the baseline scenario. Values in $\mathrm{kgN} \mathrm{ha}^{-1}$ year-1. $^{-1}$ 
Exploring the possibilities of parsimonious nitrogen modelling in different ecosystems

Therefore, taking into account the lack of data and that model implementation is used only to run model simulations in order to obtain a baseline scenario and projections of different ecosystem behaviours through best management scenarios (Özcan et al., 2017a), the results of the model implementation were considered satisfactory.

\subsubsection{Evaluation of best management practices scenarios}

A general overview of all the management practices scenarios effectiveness is shown in Figure 4-20 and it is noticeable that nitrogen loss and sediment yield are highly variable between scenarios, while crop yield takes similar values, except for the $\mathrm{FM}+\mathrm{CR}$ scenario, due to the reduction of cultivated crops.
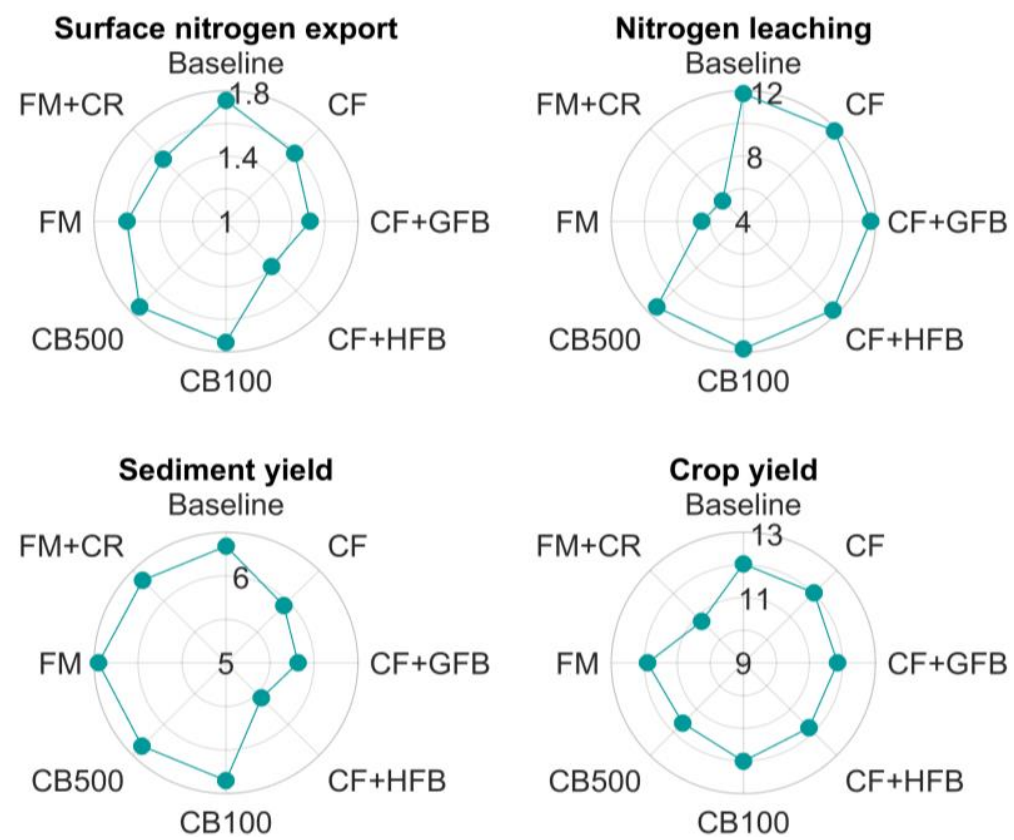

Figure 4-20 I Surface nitrogen export $\left(\mathrm{kgN} \mathrm{ha}^{-1} \mathrm{year}^{-1}\right)$, nitrogen leaching $\left(\mathrm{kgN} \mathrm{ha}^{-1} \mathrm{year}^{-1}\right)$, sediment yield $\left(\mathrm{Mg} \mathrm{ha}^{-1}\right.$ year-1 $)$ and crop dry matter yield $\left(\mathrm{Mg} \mathrm{ha}^{-1}\right.$ year-1 $\left.^{-1}\right)$ for each management practice scenario and the baseline scenario. $\mathrm{CF}$ is contour farming, $\mathrm{CF}+\mathrm{GFB}$ is contour farming and grassy field borders, $\mathrm{CF}+\mathrm{HFB}$ is contour farming and hedgerow field borders, CB100 is $100 \mathrm{~m}$ coastal line buffer, CB500 is $500 \mathrm{~m}$ coastal line buffer, FM is fertilizer management and $\mathrm{FM}+\mathrm{CR}$ is fertilizer management and two-crop rotation. 
Exploring the possibilities of parsimonious nitrogen modelling in different ecosystems

In terms of sediment yield, the scenarios willing to change the field operation management strategies $(\mathrm{CF}, \mathrm{CF}+\mathrm{GFB}$ and $\mathrm{CF}+\mathrm{HFB})$ were the most effective (Figure 4-20), leading to percentage reductions of 6.5, 8.3 and $12.1 \%$ respectively, while no significant impact was observed on crop yield (Figure 4-21). The effectiveness of the implementation of contour farming, vegetative field borders or filter strips with the objective of reducing sediment yield has been previously and widely analysed under different climates and have reported similar results. Giri et al. (2014) found that contour farming was statistically significant in reducing sediment yield. López-Ballesteros et al. (2019) found that it was possible to reduce sediment yield by $6 \%$ in one of the basins of the study area applying contour farming, but this reduction could reach $7 \%$ in the case of combining it with hedgerow field borders of 3 $\mathrm{m}$ width. Arabi et al. (2008) obtained percentage reductions of $5 \%$ in the case of contour farming and $3 \%$ in the case of vegetated field borders of $5 \mathrm{~m}$ width, that considering an additive effect, the combined reduction effectiveness can be estimated in $8 \%$, value that can be compared to the $8.3 \%$ reduction obtained in the CF+GFB scenario. Likewise, Lam et al. (2011) considered the installation of vegetative filter strips of $10 \mathrm{~m}$ width, whose effectiveness can be compared with that of the grassy field borders (Arabi et al., 2008), and reduced sediment yield by $4.9 \%$. Hence, from the point of view of the ecosystem, the implementation of contour farming combined with the installation of hedgerow field borders may be the best strategy, nonetheless, the farmers may not be willing to install hedgerow field borders due to the cultivation area reduction. In that sense, the installation of filter strips, which are installed along the edge of streams, are significantly more effective per unit area (Arabi et al., 2008).

The other scenarios results, however, were different. No impact was found in the sediment yield in the case of the FM+CR scenario, but negative impacts were found in the CB100, CB500 and FM scenarios (Figure 4-20). On the one hand, the CB100 and CB500 scenarios showed a negligible negative impact, 
with an increment of $0.16 \%$ caused by the land use change. The recommended $\mathrm{C}$-factor value in the case of irrigated agriculture (i.e., horticultural crops) is 0.04 , while in the case of natural grasslands the corresponding value is 0.12 (Alatorre et al., 2010), which increased soil erosion in the buffer area. On the other hand, the FM scenario showed an increment in sediment yield of $1.74 \%$. As the harvest date of the lettuce was brought forward (Table 4-4), during the final days of December runoff increased due to the evapotranspiration reduction, and consequently, soil erosion and sediment yield increased. Nevertheless, despite having reduced the number of crops, the FM+CR scenario showed no impact on sediment yield. As the non-considered crop was the melon, which is cultivated during the driest months, the evapotranspiration reduction did not increment surface runoff, since precipitation is scarce during those months.

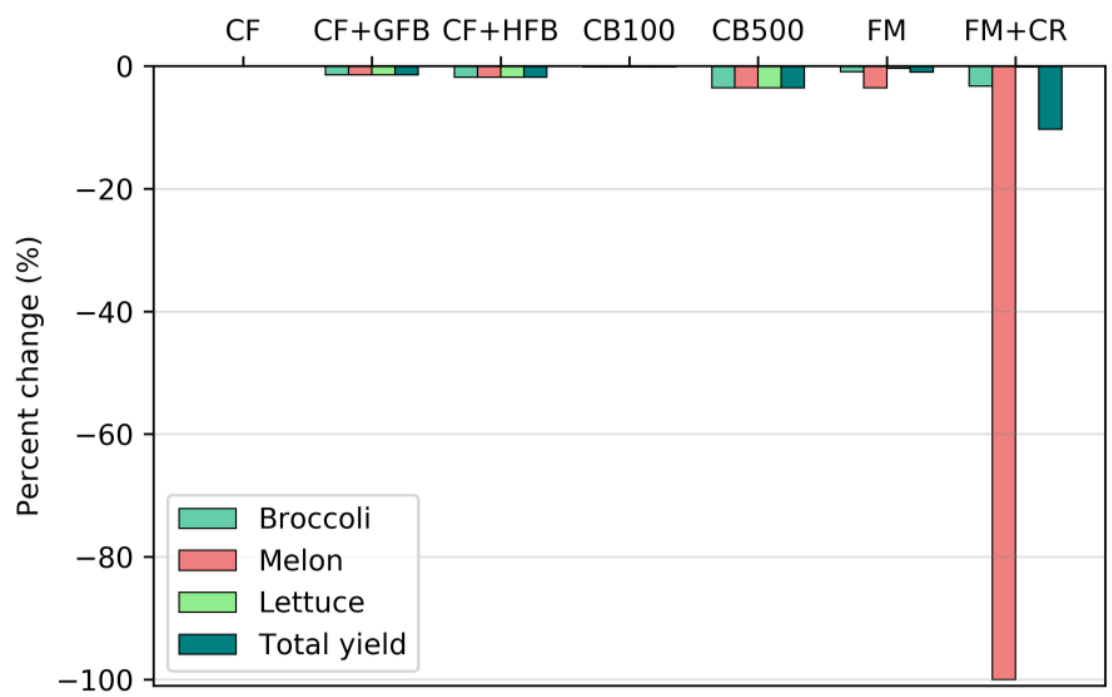

Figure 4-21 I Crop yield percentage reductions for each management practice scenario. $\mathrm{CF}$ is contour farming, $\mathrm{CF}+\mathrm{GFB}$ is contour farming and grassy field borders, $\mathrm{CF}+\mathrm{HFB}$ is contour farming and hedgerow field borders, CB100 is $100 \mathrm{~m}$ coastal line buffer, CB500 is $500 \mathrm{~m}$ coastal line buffer, FM is fertilizer management and FM+CR is fertilizer management and two-crop rotation.

Regarding the surface nitrogen export, both the scenarios willing to change the field operation management strategies (CF, CF+GFB and $\mathrm{CF}+\mathrm{HFB})$ and 
Exploring the possibilities of parsimonious nitrogen modelling in different ecosystems

the scenarios which considerably reduced the total fertilizer amount (FM and $\mathrm{FM}+\mathrm{CR}$ ) were effective (Figure 4-20), although as shown in Figure 4-22, each scenario was effective in reducing a different nitrogen form. On the one hand, the $\mathrm{CF}, \mathrm{CF}+\mathrm{GFB}$ and $\mathrm{CF}+\mathrm{HFB}$ scenarios were more effective in reducing the organic nitrogen and the sorbed $\mathrm{N}-\mathrm{NH}_{4}{ }^{+}$(Figure 4-22) because these nitrogen forms are fixed to the sediments and their mobilization is associated to soil erosion and sediment yield, while $\mathrm{N}-\mathrm{NO}_{3}$ - is more prone to be lost by leaching than via surface runoff (Randall and Mulla, 2001). This effect was also observed by Himanshu et al. (2019) who found that contour farming and the installation of filter strips led to higher percentage

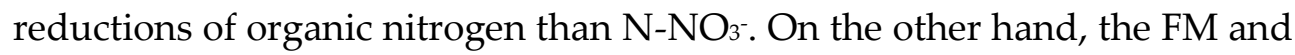
$\mathrm{FM}+\mathrm{CR}$ scenarios were effective in reducing the $\mathrm{N}^{-\mathrm{NO}_{3}}{ }^{-}$. Although $\mathrm{N}^{-\mathrm{NO}_{3}}{ }^{-}$ is more prone to be lost by leaching (Porporato et al., 2003; Randall and Mulla, 2001), as the fertilizer doses were adjusted to the real crops requirements and distributed according to their growing curve, the $\mathrm{N}^{-\mathrm{NO}_{3}}$ available to be mobilized by surface runoff was highly reduced, which consequently led to important surface $\mathrm{N}_{-} \mathrm{NO}_{3}{ }^{-}$export reductions. However, it should be highlighted that the FM scenario slightly increased surface organic nitrogen export because surface runoff increased and additionally, that the FM+CR scenario obtained a significant crop yield reduction (Figure 4-21), since it contemplates a two-crop rotation (broccoli and lettuce), while the others considered a three-crop rotation.

In terms of total surface nitrogen export, the $\mathrm{CF}, \mathrm{CF}+\mathrm{GFB}$ and $\mathrm{CF}+\mathrm{HFB}$ scenarios obtained percentage reductions of 8.6, 13.0 and 20.0\% (Figure 4-22), respectively. Similarly, Giri et al. (2014) found that contour farming was statistically significant in reducing nitrogen yield, Haas et al. (2017) found that filter strips of 1.5 and $3 \mathrm{~m}$ width could reduce nitrogen export by 3.9 and $5.8 \%$, respectively, and Lam et al. (2011) obtained that the effectiveness of a $10 \mathrm{~m}$ width filter strip was $12.9 \%$, all values very similar to the ones obtained in this study. Additionally, the FM and FM+CR scenarios, which represent 
Exploring the possibilities of parsimonious nitrogen modelling in different ecosystems total fertilizer reductions of 16.5 and $30.3 \%$, reduced surface nitrogen export by 8.1 and $11.5 \%$ (Figure 4-22), respectively. In that sense, Haas et al. (2017) obtained nitrogen export reductions of 15.1 and 25\%, applying fertilizer reductions of 15 and 30\% respectively, Lam et al. (2011) applied a $20 \%$ fertilizer reduction and obtained that nitrogen export could be reduced by 8.6\%, Jang et al. (2017) considered 10, 20 and 30\% fertilizer reductions and reduced nitrogen export by 5.2, 10.5 and $15.6 \%$, respectively, Özcan et al. $(2017 \mathrm{~b})$ proposed a $30 \%$ fertilizer reduction and obtained a nitrogen export reduction of $6.0 \%$, and Cavero et al. (2012) applied fertilizer doses at optimum rates and reduced nitrogen export by $17 \%$. Hence, although a different effectiveness is obtained depending on the watershed specific characteristics, in this case the CF+HFB and FM scenarios results showed that surface nitrogen export can be reduced with minimal impact on crop yield. The CB100 and CB500 scenarios had no significant impact on reducing surface nitrogen export.

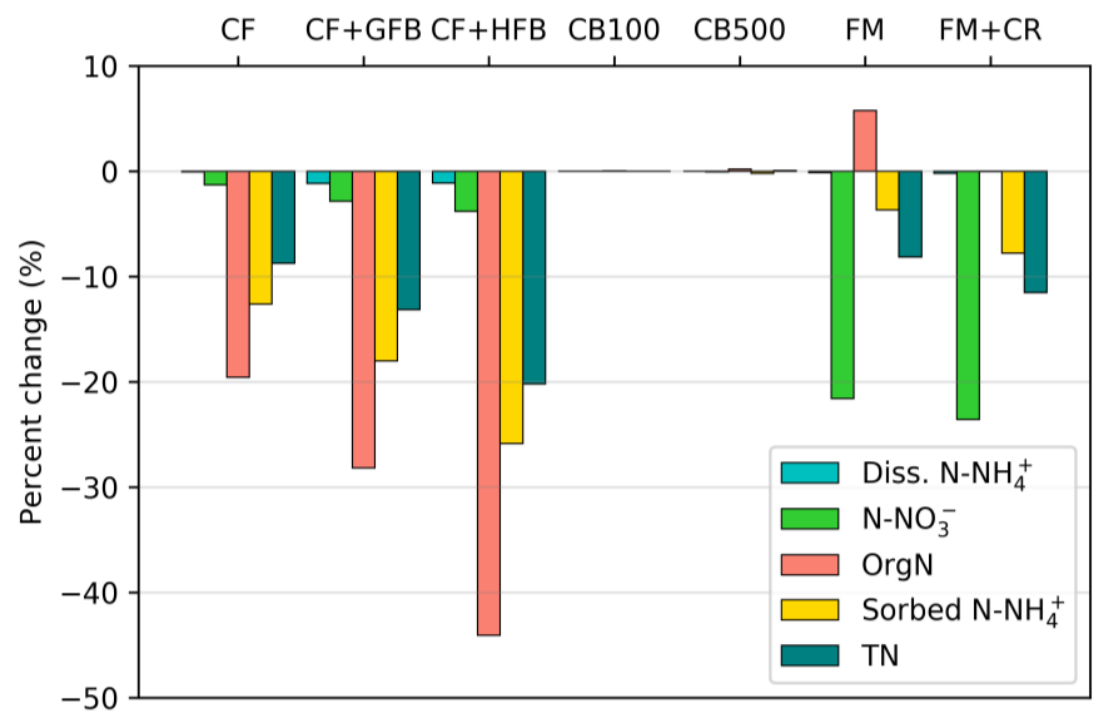

Figure 4-22 I Surface nitrogen export percentage reductions for each management practice scenario. CF is contour farming, $\mathrm{CF}+\mathrm{GFB}$ is contour farming and grassy field borders, $\mathrm{CF}+\mathrm{HFB}$ is contour farming and hedgerow field borders, CB100 is $100 \mathrm{~m}$ coastal line buffer, CB500 is $500 \mathrm{~m}$ coastal line buffer, FM is fertilizer management and FM+CR is fertilizer management and two-crop rotation. 
Exploring the possibilities of parsimonious nitrogen modelling in different ecosystems Finally, Figure 4-23 shows the effectiveness of each management practice scenario in reducing nitrogen leaching, a very important factor in this area, since direct groundwater discharge has been recognized as the main source of nutrients (Jiménez-Martínez et al., 2016). As expected, only the FM and $\mathrm{FM}+\mathrm{CR}$ scenarios presented a noteworthy impact. The FM was able to reduce $\mathrm{N}-\mathrm{NO}_{3}{ }^{-}$leaching by $45.8 \%$ and total nitrogen leaching by $44.8 \%$, while the FM+CR scenario by $52.1 \%$ and $51.1 \%$, respectively. Likewise, De Paz and Ramos (2004) applied a similar method ( $N_{\min }$ method) and found that ${\mathrm{N}-\mathrm{NO}_{3}}^{-}$ leaching could be reduced by $66 \%$, barely reducing nitrogen crop uptake.

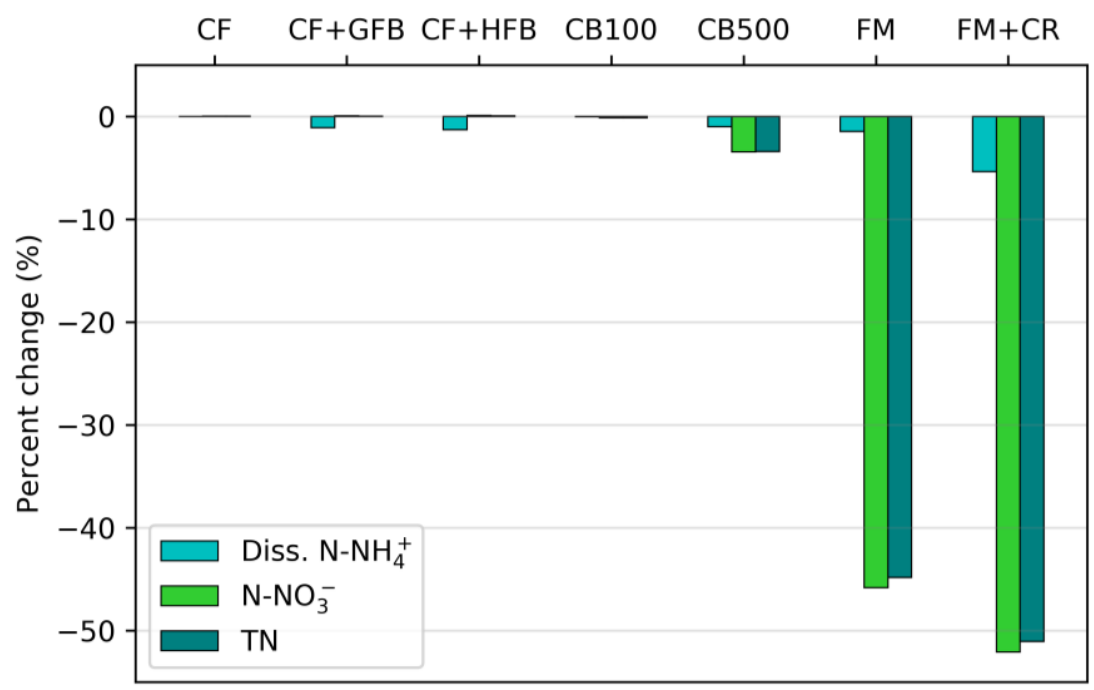

Figure 4-23 | Nitrogen leaching percentage reductions for each management practice scenario. $\mathrm{CF}$ is contour farming, $\mathrm{CF}+\mathrm{GFB}$ is contour farming and grassy field borders, $\mathrm{CF}+\mathrm{HFB}$ is contour farming and hedgerow field borders, CB100 is $100 \mathrm{~m}$ coastal line buffer, CB500 is $500 \mathrm{~m}$ coastal line buffer, FM is fertilizer management and FM+CR is fertilizer management and two-crop rotation.

As previously discussed, the FM+CR scenario had a significant impact on crop yield (Figure 4-21); however, the FM scenario had no significant impact on crop yield. Above the strictly nitrogen crop requirement, crop yield levels off at the maximum and leaching gradually increases as more fertilizer is applied above the requirement without increasing crop yield (Giménez et al., 2016; He et al., 2012). Therefore, reducing the fertilizer amount in the 
Exploring the possibilities of parsimonious nitrogen modelling in different ecosystems scenario FM had no significant impact on crop yield and obtained similar N$\mathrm{NO}_{3}{ }^{-}$and total nitrogen leaching reductions to the $\mathrm{FM}+\mathrm{CR}$ scenario (Figure 4-24 and Figure 4-25).

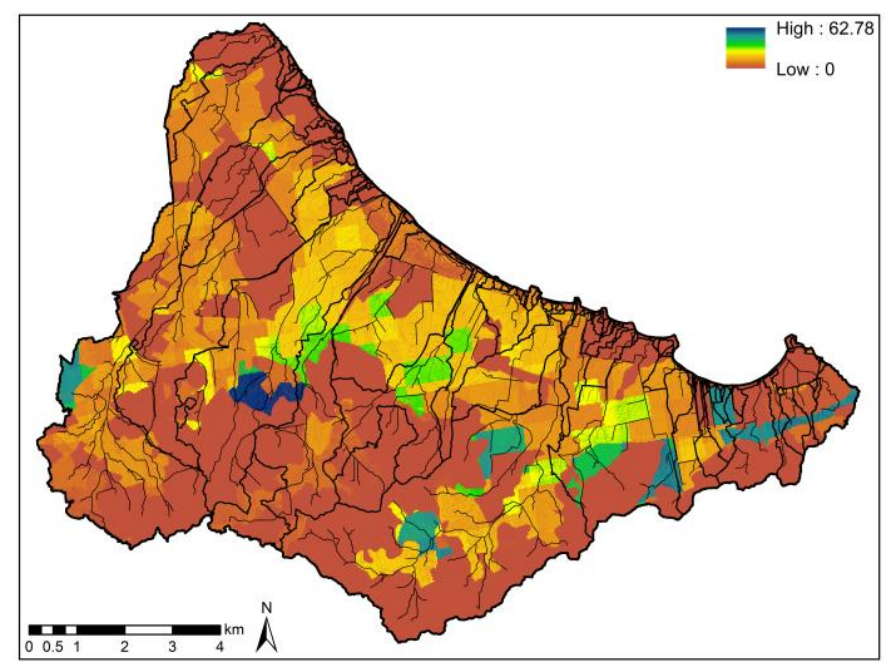

Figure 4-24 I Total nitrogen leaching for the FM (fertilizer management) scenario. Values in $\mathrm{kgN} \mathrm{ha}^{-1}$ year $^{-1}$.

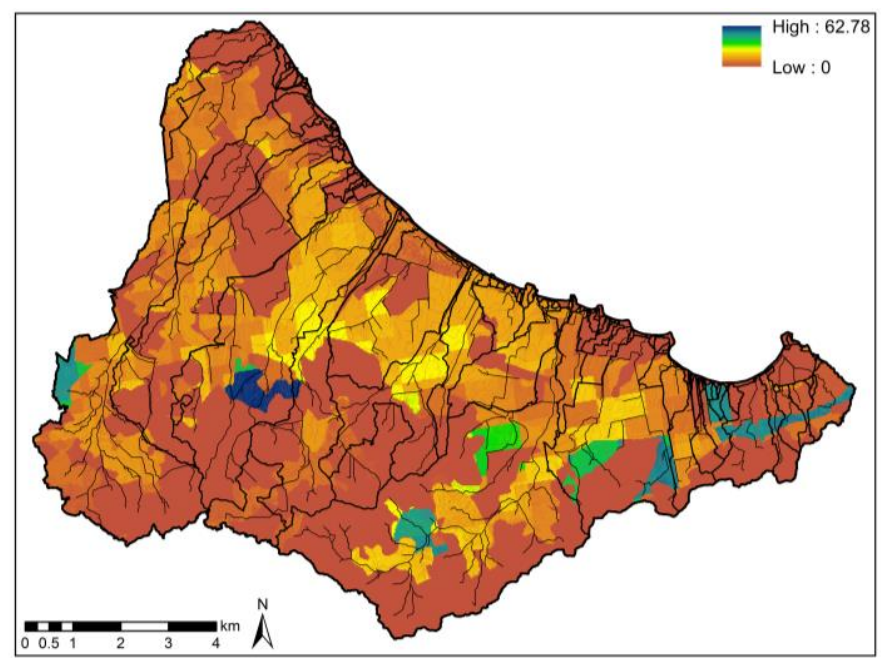

Figure 4-25 I Total nitrogen leaching for the FM+CR (fertilizer management and two-crop rotation) scenario. Values in $\mathrm{kgN} \mathrm{ha}^{-1}$ year-1. $^{-1}$ 
Exploring the possibilities of parsimonious nitrogen modelling in different ecosystems

The impact of both scenarios was negligible in the case of $\mathrm{N}-\mathrm{NH}_{4}{ }^{+}$because it is easily nitrified and attracted to the negatively charged surfaces of clays and humus, partially protecting it from leaching (Porporato et al., 2003).

\subsection{Conclusions}

In this approach, the effectiveness of several management practices was evaluated in terms of sediment yield, surface nitrogen export, nitrogen leaching and crop yield at the Mar Menor semiarid coastal watershed, which is characterized by intensive irrigated agriculture and by the need for fast and effective management in order to minimize the lagoon deterioration.

In terms of sediment yield, the results suggest that contour farming (CF) is crucial, obtaining an important reduction with no impact on crop yield, while its combination with hedgerow field borders $(\mathrm{CF}+\mathrm{HFB})$ results the best option, from the point of view of the ecosystem. Nevertheless, from the point of view of the farmers, hedgerow field borders may substantially reduce the cultivation area, and hence, filter strips along the edge of streams, which effectiveness per unit area is higher, may be a better option. Regarding surface nitrogen export, the combination of contour farming and hedgerow field borders $(\mathrm{CF}+\mathrm{HFB})$ is very effective in reducing organic nitrogen and sorbed $\mathrm{N}-\mathrm{NH}_{4}{ }^{+}$export, nitrogen forms highly related to soil erosion and sediment yield, while the scenarios willing to reduce the amount of fertilizer applied (FM and FM+CR) are very effective in reducing the surface ${\mathrm{N}-\mathrm{NO}_{3}}^{-}$ export, although the latter presents higher total surface nitrogen export reductions. Nonetheless, the differences between both fertilizer management scenarios (FM and FM+CR) are negligible considering the elevated crop yield reduction due to the change in the productive cultivation system from a three-crop rotation to a two-crop rotation, being the fertilizer management with a three-crop rotation (FM) an adequate choice. Additionally, these two scenarios highly reduced nitrogen leaching, however, as in the case of surface nitrogen export, due to the elevated crop yield reduction, the 
Exploring the possibilities of parsimonious nitrogen modelling in different ecosystems

fertilizer management with a three-crop rotation (FM) remains an adequate choice. The effectiveness of both coastal line buffers is completely insignificant.

In view of the foregoing, each management practice is effective in reducing a certain type of diffuse pollution, and therefore, combined scenarios are necessary to cope with all agricultural pollution sources. In that sense, contour farming and hedgerow field borders (CF+HFB) combined with an effective fertilizer management $(\mathrm{FM})$ is an appropriate scenario to reduce diffuse pollution. As fertilizer management (FM) is based on a rational soilplant nitrogen mass balance, it is possible to highly reduce surface nitrogen export and leaching without changing the productive cultivation system and thus, without a significant impact on crop yield. 



\section{Conclusions}

\subsection{Concluding remarks}

Environmental mathematical models have become a widespread tool used by researchers, engineers and public agencies to improve the current understanding of ecosystems and as a basis for policy and decision-making. Nonetheless, in the case of the nitrogen cycle modelling there is a lack of models especially suited to be applied in semiarid environments that integrate both natural and anthropogenic ecosystems characteristics and behaviours. Therefore, even nowadays, it is essential to continue the research activity on nitrogen cycle modelling and model applicability.

As stated in the first chapter, this thesis aims to improve the nitrogen cycle modelling under the principle of parameter parsimony. In the last decades, the number of biogeochemistry models has considerably increased, but these 
Exploring the possibilities of parsimonious nitrogen modelling in different ecosystems models usually have high parameter requirements and consequently, its applicability is frequently limited, especially its application to large areas. In that sense, this thesis targets exploring different parsimonious approaches to model de nitrogen cycle within the plant-soil-water continuum in natural and anthropogenic semiarid ecosystems, and it attempts to understand how the nitrogen cycle interacts with water, vegetation and sediments and how these interactions can be modelled.

As previously introduced, there is a necessity of preserving natural ecosystems over time and improving the sustainability of anthropogenic ecosystems. Hence, a progressive understanding approach consisting in the nitrogen cycle modelling in two different data availability scenarios was adopted; a semiarid natural forest ecosystem and a semiarid anthropogenic agricultural watershed.

The first approach of this research focuses on a semiarid natural forest ecosystem, mainly dominated by facultative phreatophytes. Since in natural ecosystems mineral nitrogen release is controlled by the microbial activity, the carbon and nitrogen cycles are biologically coupled, and hence, the new parsimonious TETIS-CN model, which includes a carbon and nitrogen submodel, was developed and implemented in this experimental plot. Moreover, the capability of TETIS-CN to reproduce the hydrology and biogeochemistry of the forest was compared against a physically-based model, BIOME, and a process-based model, LEACHM. The three models obtained similar results, none of them stood out from the rest in reproducing the hydrology or the biogeochemistry of this natural forest ecosystem, which makes TETIS-CN a suitable tool to evaluate possible forest management practices or climate change impacts, among others, and thereby help preserve these ecosystems. Nevertheless, these results could be and were considered satisfactory, although they highlighted some deficiencies regarding model implementation and development. 
Regarding model implementation, firstly, no carbon measurement was included in the calibration process and, although TETIS-CN obtained acceptable results in terms of heterotrophic soil respiration, the only carbonrelated measurement, neither BIOME nor LEACHM could obtain reliable results. However, nitrogen mineralization was accurately reproduced by all the models, which points out that the available measurements were not enough to measure all the characteristics of the system. Secondly, no all the species were considered. $Q$. ilex coexists with other species with a different behaviour whose plant uptake may be significant and which should be included in the modelling. With regard to model development the results suggested that a fixed daily potential uptake may not be appropriate to reproduce plant nitrogen uptake, which presents a clear seasonality, and highlights the importance of coupling TETIS-CN to a vegetation growth model.

The second approach focuses on an intensive irrigated agricultural watershed under a semiarid climate. Agricultural areas are characterized by an elevated use of fertilizers, being nitrogen pollution of water bodies one of its main associated environmental impacts. Conversely, the main mineral nitrogen input in these areas is not the natural nitrogen mineralization. For this reason, the parsimonious TETIS-N model does not include the carbon cycle, because a precise modelling of the nitrogen mineralization process is not necessary in these areas and the modelling of this process can be simply replaced by a mineralization constant. However, soils are rich in nitrogen and soil erosion is usually high and, consequently, TETIS-N includes the coupling of the water, nitrogen and sediment cycles. Moreover, since in the first approach it was noticeable that there was a need to couple the model to a vegetation growth model, in this case, in which horticultural crops are the dominant land use and crops have an even more marked seasonality in the nitrogen uptake than forests, TETIS-N also incorporates a crop growth submodel. 
Exploring the possibilities of parsimonious nitrogen modelling in different ecosystems

Due to the lack of observed data, it was not possible to appropriately check the correct functioning of TETIS-N; however, after a deep analysis and comparison with previous studies developed in the same area, the results were considered satisfactory. The implemented model was used to evaluate the effectiveness of several best management practices scenarios in terms of sediment yield, surface nitrogen and crop yield, because improving the sustainability of agricultural areas is crucial. The results suggested that each management practice is effective in reducing a certain type of diffuse pollution, and combined scenarios are necessary to cope with all agricultural pollution sources.

In short, this thesis makes clear that each ecosystem has different characteristics and behaviours and consequently, different nitrogen modelling necessities. Therefore, current models should include an integrate modelling of both natural and anthropogenic ecosystems with different nitrogen modelling for each of them, which will be in line with the principle that everything should be made as simple as possible, but not simpler (Stocker et al., 2016).

\subsection{Future research lines}

Since the result of this thesis are two environmental mathematical tools, the main future research line should be focused on the constant development of these models. Therefore, both models, TETIS-CN and TETIS-N, should be merged and coupled at watershed scale as a new nitrogen sub-model for the current TETIS model. Since TETIS is a distributed model, two different conceptualizations for nitrogen modelling can be used depending on the land use. Therefore, it can be programmed in such a way that in the natural areas of a watershed, the conceptualization of TETIS-CN is used, while in anthropogenic ecosystems or in data limited areas, the TETIS-N conceptualization is used. This new model should be properly tested against observed data in a highly monitored watershed. 
Additionally, it is important to continue collecting the measurements and to collect more carbon-related measurements in the experimental plot of $\mathrm{La}$ Hunde. This will allow to better test the TETIS-CN model and improve the understanding of the transport, storage and transformation of the nitrogen in the environment.

Furthermore, a sensitivity analysis should be carried out in both, TETIS-CN and TETIS-N to evaluate model parameter influence in the results and to probably further reduce model complexity.

Complementarily, an uncertainty analysis of the parameters maps could be of great interest to improve model performance.

Other challenging task could be the calibration of the watershed model using a multi-variable calibration with a multi-objective approach. This approach was thoroughly analysed in the case of the plot scale hydrological calibration where the results of the multi-variable and multi-objective calibration of LEACHM and TETIS-CN were compared against the traditional singlevariable and single-objective calibration (Puertes et al., 2019). The results showed how the multi-variable and multi-objective approach kept the parameter set as realistic as possible without obtaining a poorly representation of the non-calibrated state variables or an unreal water balance closure. Therefore, at watershed scale, working with the water, sediment and nitrogen cycles, a multi-variable and multi-objective calibration could be a better tool, provided enough data.

Finally, coupling the model to a vegetation growth model has resulted necessary after this research, because vegetation presents a clear seasonality in the nitrogen uptake process. Currently, TETIS has a dynamic vegetation sub-model for natural ecosystems, which simulates vegetation growth. Therefore, it is possible to couple the TETIS-CN model to the current 
Exploring the possibilities of parsimonious nitrogen modelling in different ecosystems dynamic vegetation model. In the case of agricultural areas, the TETIS-N model already includes a crop growth sub-model. 


\section{6}

\section{References}

Abbaspour, K.C., Yang, J., Maximov, I., Siber, R., Bogner, K., Mieleitner, J., Zobrist, J., Srinivasan, R., 2007. Modelling hydrology and water quality in the prealpine/alpine Thur watershed using SWAT. J. Hydrol. 333, 413-430. https://doi.org/10.1016/J.JHYDROL.2006.09.014

Abrahamsen, P., Hansen, S., 2000. Daisy: An open soil-crop-atmosphere system model. Environ. Model. Softw. 15, 313-330. https://doi.org/10.1016/S13648152(00)00003-7

Alatorre, L.C., Beguería, S., García-Ruiz, J.M., 2010. Regional scale modeling of hillslope sediment delivery: A case study in the Barasona Reservoir watershed (Spain) using WATEM/SEDEM. J. Hydrol. 391, 109-123. https://doi.org/10.1016/j.jhydrol.2010.07.010

Albaladejo Montoro, J., Ortiz Silla, R., Martinez-Mena Garcia, M., 1988. Evaluation and mapping of erosion risks: An example from S.E. Spain. Soil Technol. 1, 7787. https://doi.org/10.1016/S0933-3630(88)80007-2

Albornoz, F., Lieth, J.H., 2016. Daily macronutrient uptake patterns in relation to 
Exploring the possibilities of parsimonious nitrogen modelling in different ecosystems

plant age in hydroponic lettuce. J. Plant Nutr. 39, 1357-1364. https://doi.org/10.1080/01904167.2015.1109110

Alcolea, A., Contreras, S., Hunink, J.E., García-Aróstegui, J.L., Jiménez-Martínez, J., 2019. Hydrogeological modelling for the watershed management of the Mar Menor coastal lagoon (Spain). Sci. Total Environ. 663, 901-914. https://doi.org/10.1016/j.scitotenv.2019.01.375

Allen, R.G., Pereira, L.S., Raes, D., Smith, M., 1998. Crop evapotranspiration: Guidelines for computing crop water requirements. Irrigation and Drainage Paper. 56, FAO.

Alvarez-Cobelas, M., Angeler, D.G., Sánchez-Carrillo, S., 2008. Export of nitrogen from catchments: A worldwide analysis. Environ. Pollut. 156, 261-269. https://doi.org/10.1016/j.envpol.2008.02.016

Álvarez-Rogel, J., Jiménez-Cárceles, F.J., Nicolás, C.E., 2006. Phosphorus and nitrogen content in the water of a coastal wetland in the Mar Menor lagoon (Se Spain): Relationships with effluents from urban and agricultural areas. Water. Air. Soil Pollut. 173, 21-38. https://doi.org/10.1007/s11270-005-9020-y

Álvarez, X., Valero, E., Santos, R.M.B., Varandas, S.G.P., Sanches Fernandes, L.F., Pacheco, F.A.L., 2017. Anthropogenic nutrients and eutrophication in multiple land use watersheds: Best management practices and policies for the protection of water resources. Land use policy 69, 1-11. https://doi.org/10.1016/j.landusepol.2017.08.028

Aponte, C., Marañón, T., García, L. V., 2010. Microbial C, N and P in soils of Mediterranean oak forests: Influence of season, canopy cover and soil depth. Biogeochemistry 101, 77-92. https://doi.org/10.1007/s10533-010-9418-5

Arabi, M., Frankenberger, J.R., Engel, B.A., Arnold, J.G., 2008. Representation of agricultural conservation practices with SWAT. Hydrol. Process. 22, 30423055. https://doi.org/10.1002/hyp.6890

Arnold, J.G., Srinivasan, R., Muttiah, R.S., Williams, J.R., 1998. Large area hydrologic modeling and assessment part I: Model development. J. Am. Water Resour. Assoc. 34, 73-89. https://doi.org/10.1111/j.1752-1688.1998.tb05961.x

Asada, K., Eguchi, S., Tsunekawa, A., Tsuji, M., Itahashi, S., Katou, H., 2015. Predicting nitrogen leaching with the modified LEACHM model: validation in soils receiving long-term application of animal manure composts. Nutr. Cycl. Agroecosystems 102, 209-225. https://doi.org/10.1007/s10705-015-9690-9 
Exploring the possibilities of parsimonious nitrogen modelling in different ecosystems

Asada, K., Eguchi, S., Urakawa, R., Itahashi, S., Matsumaru, T., Nagasawa, T., Aoki, K., Nakamura, K., Katou, H., 2013. Modifying the LEACHM model for processbased prediction of nitrate leaching from cropped Andosols. Plant Soil 373, 609-625. https://doi.org/10.1007/s11104-013-1809-7

Asseng, S., Ewert, F., Martre, P., Rötter, R.P., Lobell, D.B., Cammarano, D., Kimball, B.A., Ottman, M.J., Wall, G.W., White, J.W., Reynolds, M.P., Alderman, P.D., Prasad, P.V.V., Aggarwal, P.K., Anothai, J., Basso, B., Biernath, C., Challinor, A.J., De Sanctis, G., Doltra, J., Fereres, E., Garcia-Vila, M., Gayler, S., Hoogenboom, G., Hunt, L.A., Izaurralde, R.C., Jabloun, M., Jones, C.D., Kersebaum, K.C., Koehler, A.K., Müller, C., Naresh Kumar, S., Nendel, C., O'leary, G., Olesen, J.E., Palosuo, T., Priesack, E., Eyshi Rezaei, E., Ruane, A.C., Semenov, M.A., Shcherbak, I., Stöckle, C., Stratonovitch, P., Streck, T., Supit, I., Tao, F., Thorburn, P.J., Waha, K., Wang, E., Wallach, D., Wolf, J., Zhao, Z., Zhu, Y., 2015. Rising temperatures reduce global wheat production. Nat. Clim. Chang. 5, 143-147. https://doi.org/10.1038/nclimate2470

Austin, A.T., Yahdjian, L., Stark, J.M., Belnap, J., Porporato, A., Norton, U., Ravetta, D.A., Schaeffer, S.M., 2004. Water pulses and biogeochemical cycles in arid and semiarid ecosystems. Oecologia 141, 221-235. https://doi.org/10.1007/s00442004-1519-1

Ballabio, C., Panagos, P., Monatanarella, L., 2016. Mapping topsoil physical properties at European scale using the LUCAS database. Geoderma 261, 110123. https://doi.org/10.1016/j.geoderma.2015.07.006

Balugani, E., Lubczynski, M.W., Reyes-Acosta, L., van der Tol, C., Francés, A.P., Metselaar, K., 2017. Groundwater and unsaturated zone evaporation and transpiration in a semi-arid open woodland. J. Hydrol. 547, 54-66. https://doi.org/10.1016/j.jhydrol.2017.01.042

Baquedano, F.J., Castillo, F.J., 2007. Drought tolerance in the Mediterranean species Quercus coccifera, Quercus ilex, Pinus halepensis, and Juniperus phoenicea. Photosynthetica 45, 229-238. https://doi.org/10.1007/s11099-007-0037-x

Barbeta, A., Peñuelas, J., 2017. Relative contribution of groundwater to plant transpiration estimated with stable isotopes. Sci. Rep. 7, 10580. https://doi.org/10.1038/s41598-017-09643-x

Barbeta, A., Peñuelas, J., 2016. Sequence of plant responses to droughts of different timescales: lessons from holm oak (Quercus ilex) forests. Plant Ecol. Divers. 9, 321-338. https://doi.org/10.1080/17550874.2016.1212288 
Exploring the possibilities of parsimonious nitrogen modelling in different ecosystems

Batlle-Aguilar, J., Brovelli, A., Porporato, A., Barry, D.A., 2011. Modelling soil carbon and nitrogen cycles during land use change. A review. Agron. Sustain. Dev. 31, 251-274. https://doi.org/10.1051/agro/2010007

Bautista, I., Pabón, C., Lull, C., González-Sanchís, M., Lidón, A., Del Campo, A.D., 2015. Efectos de la gestión forestal en los flujos de nutrientes asociados al ciclo hidrológico en un bosque mediterráneo de Quercus Ilex. Cuad. la Soc. Española Ciencias For. 41, 343-354.

Bengtsson, J., Nilsson, S.G., Franc, A., Menozzi, P., 2000. Biodiversity, disturbances, ecosystem function and management of european forests. For. Ecol. Manage. 132, 39-50. https://doi.org/10.1016/S0378-1127(00)00378-9

Beven, K., 1993. Prophecy, reality and uncertainty in distributed hydrological modelling. Adv. Water Resour. 16, 41-51. https://doi.org/10.1016/03091708(93)90028-E

Blanco, J.A., Zavala, M.A., Imbert, J.B., Castillo, F.J., 2005. Sustainability of forest management practices: Evaluation through a simulation model of nutrient cycling. For. Ecol. Manage. 213, 209-228. https://doi.org/10.1016/j.foreco.2005.03.042

Boix-Fayos, C., Martínez-Mena, M., Calvo-Cases, A., Castillo, V., Albaladejo, J., 2005. Concise review of interrill erosion studies in SE Spain (Alicante and Murcia): Erosion rates and progress of knowledge from the 1980's. L. Degrad. Dev. https://doi.org/10.1002/ldr.706

Bonilla, D., Rodà, F., 1992. Soil nitrogen dynamics in a holm oak forest. Vegetatio 99-100, 247-257. https://doi.org/10.1007/BF00118231

Botter, G., Daly, E., Porporato, A., Rodriguez-Iturbe, I., Rinaldo, A., 2008. Probabilistic dynamics of soil nitrate: Coupling of ecohydrological and biogeochemical processes. Water Resour. Res. 44, 15. https://doi.org/10.1029/2007WR006108

Brady, N.C., Weil, R.R., 2002. The nature and properties of soils, 13th ed. Upper Saddle River, New Jersey: Prentice-Hall.

Britto, D.T., Kronzucker, H.J., 2013. Ecological significance and complexity of Nsource preference in plants. Ann. Bot. 112, 957-963. https://doi.org/10.1093/aob/mct157

Burgess, S.S.O., Adams, M.A., Turner, N.C., Beverly, C.R., Ong, C.K., Khan, A.A., 
Exploring the possibilities of parsimonious nitrogen modelling in different ecosystems

Bleby, T.M., 2001. An improved heat pulse method to measure low and reverse rates of sap flow in woody plants. Tree Physiol. 21, 589-98.

Bussi, G., Francés, F., Montoya, J.J., Julien, P.Y., 2014. Distributed sediment yield modelling: Importance of initial sediment conditions. Environ. Model. Softw. 58, 58-70. https://doi.org/10.1016/j.envsoft.2014.04.010

Bussi, G., Rodríguez-Lloveras, X., Francés, F., Benito, G., Sánchez-Moya, Y., Sopeña, A., 2013. Sediment yield model implementation based on check dam infill stratigraphy in a semiarid Mediterranean catchment. Hydrol. Earth Syst. Sci. 17, 3339-3354. https://doi.org/10.5194/hess-17-3339-2013

CAAMA, 2016a. Proyecto de acciones correctoras frente al riesgo de inundación en el entorno de las urbanizaciones de Islas Menores y Mar de Cristal. T.M. Cartagena (Murcia). Consejería de Agua, Agricultura y Medio Ambiente. Región de Murcia.

CAAMA, 2016b. Proyecto de acciones correctoras frente al riesgo de inundación en el entorno de la urbanización de Los Nietos. T.M. Cartagena (Murcia). Consejería de Agua, Agricultura y Medio Ambiente. Región de Murcia.

Calama, R., Conde, M., De-Dios-García, J., Madrigal, G., Vázquez-Piqué, J., Gordo, F.J., Pardos, M., 2019. Linking climate, annual growth and competition in a Mediterranean forest: Pinus pinea in the Spanish Northern Plateau. Agric. For. Meteorol. 264, 309-321. https://doi.org/10.1016/j.agrformet.2018.10.017

Calatrava, J., Barberá, G.G., Castillo, V.M., 2011. Farming practices and policy measures for agricultural soil conservation in semi-arid Mediterranean areas: The case of the Guadalentín basin in southeast Spain. L. Degrad. Dev. 22, 5869. https://doi.org/10.1002/1dr.1013

Cameron, D.R., Van Oijen, M., Werner, C., Butterbach-Bahl, K., Grote, R., Haas, E., Heuvelink, G.B.M., Kiese, R., Kros, J., Kuhnert, M., Leip, A., Reinds, G.J., Reuter, H.I., Schelhaas, M.J., De Vries, W., Yeluripati, J., 2013. Environmental change impacts on the $\mathrm{C}$ - and $\mathrm{N}$-cycle of European forests: A model comparison study. Biogeosciences 10, 1751-1773. https://doi.org/10.5194/bg10-1751-2013

Campbell, G.S., 1974. A simple method for determining unsaturated conductivity from moisture retention data. Soil Sci. 117, 311-314. https://doi.org/10.1097/00010694-197406000-00001

Canadell, J., Jackson, R.B., Ehleringer, J.R., Mooney, H.A., Sala, O.E., Schulze, E.D., 
Exploring the possibilities of parsimonious nitrogen modelling in different ecosystems

1996. Maximum rooting depth of vegetation types at the global scale. Oecologia 108, 583-595. https://doi.org/10.1007/BF00329030

CARM, 2018. Ley 1/2018, de 7 de febrero, de medidas urgentes para garantizar la sostenibilidad ambiental en el entorno del Mar Menor. Comunidad Autónoma de la Región de Murcia.

CARM, 2017. Decreto-Ley no. 1/2017, de 4 de abril, de medidas urgentes para garantizar la sostenibilidad ambiental en el entorno del Mar Menor. Comunidad Autónoma de la Región de Murcia.

Castillo, J.M., Rubio Casal, A.E., Luque, C.J., Luque, T., Figueroa, M.E., 2002. Comparative field summer stress of three tree species co-occurring in Mediterranean coastal dunes. Photosynthetica 40, 49-56. https://doi.org/10.1023/A:1020133921204

Causapé, J., Quílez, D., Aragüés, R., 2004. Assessment of irrigation and environmental quality at the hydrological basin level. II. Salt and nitrate loads in irrigation return flows. Agric. Water Manag. 70, 211-228. https://doi.org/10.1016/j.agwat.2004.06.006

Cavero, J., Barros, R., Sellam, F., Topcu, S., Isidoro, D., Hartani, T., Lounis, A., Ibrikci, H., Cetin, M., Williams, J.R., Aragüés, R., 2012. APEX simulation of best irrigation and $\mathrm{N}$ management strategies for off-site $\mathrm{N}$ pollution control in three Mediterranean irrigated watersheds. Agric. Water Manag. 103, 88-99. https://doi.org/10.1016/j.agwat.2011.10.021

Caylor, K.K., Manfreda, S., Rodriguez-Iturbe, I., 2005. On the coupled geomorphological and ecohydrological organization of river basins. Adv. Water Resour. 28, 69-86. https://doi.org/10.1016/j.advwatres.2004.08.013

Chen, Y., Xiao, W., 2019a. Estimation of Forest NPP and Carbon Sequestration in the Three Gorges Reservoir Area, Using the Biome-BGC Model. Forests 10, 149. https://doi.org/10.3390/f10020149

Chen, Y., Xiao, W., 2019b. Estimation of Forest NPP and Carbon Sequestration in the Three Gorges Reservoir Area, Using the Biome-BGC Model. Forests 10, 17. https://doi.org/10.3390/f10020149

Chiang, L.C., Chaubey, I., Maringanti, C., Huang, T., 2014. Comparing the selection and placement of best management practices in improving water quality using a multiobjective optimization and targeting method. Int. J. Environ. Res. Public Health 11, 2992-3014. https://doi.org/10.3390/ijerph110302992 
Exploring the possibilities of parsimonious nitrogen modelling in different ecosystems

Chiesi, M., Maselli, F., Moriondo, M., Fibbi, L., Bindi, M., Running, S.W., 2007. Application of BIOME-BGC to simulate Mediterranean forest processes. Ecol. Modell. 206, 179-190. https://doi.org/10.1016/j.ecolmodel.2007.03.032

Chukalla, A.D., Krol, M.S., Hoekstra, A.Y., 2018. Grey water footprint reduction in irrigated crop production: Effect of nitrogen application rate, nitrogen form, tillage practice and irrigation strategy. Hydrol. Earth Syst. Sci. 22, 3245-3259. https://doi.org/10.5194/hess-22-3245-2018

Clapp, R.B., Hornberger, G.M., 1978. Empirical equations for some soil hydraulic properties. Water Resour. Res. 14, 601-604. https://doi.org/10.1029/WR014i004p00601

Collins, A.L., Naden, P.S., Sear, D.A., Jones, J.I., Foster, I.D.L., Morrow, K., 2011. Sediment targets for informing river catchment management: international experience and prospects. Hydrol. Process. 25, 2112-2129. https://doi.org/10.1002/hyp.7965

Contreras, W.A., Lidón, A.L., Ginestar, D., Bru, R., 2009. Compartmental model for nitrogen dynamics in citrus orchards. Math. Comput. Model. 50, 794-805. https://doi.org/10.1016/j.mcm.2009.05.008

Cook, B.I., Mankin, J.S., Anchukaitis, K.J., 2018. Climate Change and Drought: From Past to Future. Curr. Clim. Chang. Reports 4, 164-179. https://doi.org/10.1007/s40641-018-0093-2

D’Odorico, P., Laio, F., Porporato, A., Rodriguez-Iturbe, I., 2003. Hydrologic controls on soil carbon and nitrogen cycles. II. A case study. Adv. Water Resour. 26, 5970. https://doi.org/10.1016/S0309-1708(02)00095-7

D’Odorico, P., Porporato, A., Laio, F., Ridolfi, L., Rodriguez-Iturbe, I., 2004. Probabilistic modeling of nitrogen and carbon dynamics in water-limited ecosystems, in: Ecological Modelling. Elsevier, pp. 205-219. https://doi.org/10.1016/j.ecolmodel.2004.06.005

David, T.S., Ferreira, M.I., Cohen, S., Pereira, J.S., David, J.S., 2004. Constraints on transpiration from an evergreen oak tree in southern Portugal. Agric. For. Meteorol. 122, 193-205. https://doi.org/10.1016/j.agrformet.2003.09.014

David, T.S., Henriques, M.O., Kurz-Besson, C., Nunes, J., Valente, F., Vaz, M., Pereira, J.S., Siegwolf, R., Chaves, M.M., Gazarini, L.C., David, J.S., 2007. Water-use strategies in two co-occurring Mediterranean evergreen oaks: Surviving the summer drought. Tree Physiol. 27, 793-803. 
Exploring the possibilities of parsimonious nitrogen modelling in different ecosystems

https://doi.org/10.1093/treephys/27.6.793

De Girolamo, A.M., Miscioscia, P., Politi, T., Barca, E., 2019. Improving grey water footprint assessment: Accounting for uncertainty. Ecol. Indic. 102, 822-833. https://doi.org/10.1016/j.ecolind.2019.03.040

De Pascalis, F., Pérez-Ruzafa, A., Gilabert, J., Marcos, C., Umgiesser, G., 2012. Climate change response of the Mar Menor coastal lagoon (Spain) using a hydrodynamic finite element model. Estuar. Coast. Shelf Sci. 114, 118-129. https://doi.org/10.1016/j.ecss.2011.12.002

De Paz, J.M., Ramos, C., 2004. Simulation of nitrate leaching for different nitrogen fertilization rates in a region of Valencia (Spain) using a GIS-GLEAMS system. Agric. Ecosyst. Environ. 103, 59-73. https://doi.org/10.1016/j.agee.2003.10.006

De Paz, J.M., Ramos, C., 2002. Linkage of a geographical information system with the gleams model to assess nitrate leaching in agricultural areas, in: Environmental Pollution. Elsevier, pp. 249-258. https://doi.org/10.1016/S02697491(01)00317-7

Dechmi, F., Skhiri, A., 2013. Evaluation of best management practices under intensive irrigation using SWAT model. Agric. Water Manag. 123, 55-64. https://doi.org/10.1016/j.agwat.2013.03.016

del Campo, A.D., González-Sanchis, M., García-Prats, A., Ceacero, C.J., Lull, C., 2019a. The impact of adaptive forest management on water fluxes and growth dynamics in a water-limited low-biomass oak coppice. Agric. For. Meteorol. 264, 266-282. https://doi.org/10.1016/j.agrformet.2018.10.016

del Campo, A.D., González-Sanchis, M., Lidón, A., Ceacero, C.J., García-Prats, A., 2018. Rainfall partitioning after thinning in two low-biomass semiarid forests: Impact of meteorological variables and forest structure on the effectiveness of water-oriented treatments. J. Hydrol. 565, 74-86. https://doi.org/10.1016/J.JHYDROL.2018.08.013

del Campo, A.D., González-Sanchis, M., Molina, A.J., García-Prats, A., Ceacero, C.J., Bautista, I., 2019b. Effectiveness of water-oriented thinning in two semiarid forests: The redistribution of increased net rainfall into soil water, drainage and runoff. For. Ecol. Manage. 438, 163-175. https://doi.org/10.1016/J.FORECO.2019.02.020

Delgado-Baquerizo, M., Maestre, F.T., Gallardo, A., Bowker, M.A., Wallenstein, M.D., Quero, J.L., Ochoa, V., Gozalo, B., García-Gómez, M., Soliveres, S., 
Exploring the possibilities of parsimonious nitrogen modelling in different ecosystems

García-Palacios, P., Berdugo, M., Valencia, E., Escolar, C., Arredondo, T., Barraza-Zepeda, C., Bran, D., Carreira, J.A., Chaieb, M., Conceicao, A.A., Derak, M., Eldridge, D.J., Escudero, A., Espinosa, C.I., Gaitán, J., Gatica, M.G., Gómez-González, S., Guzman, E., Gutiérrez, J.R., Florentino, A., Hepper, E., Hernández, R.M., Huber-Sannwald, E., Jankju, M., Liu, J., Mau, R.L., Miriti, M., Monerris, J., Naseri, K., Noumi, Z., Polo, V., Prina, A., Pucheta, E., Ramírez, E., Ramírez-Collantes, D.A., Romao, R., Tighe, M., Torres, D., Torres-Díaz, C., D. Ungar, E., Val, J., Wamiti, W., Wang, D., Zaady, E., 2013. Decoupling of soil nutrient cycles as a function of aridity in global drylands. Nature 502, 672-676. https://doi.org/10.1038/nature12670

DiStefano, J.F., Gholz, H.L., 1986. A proposed use of ion exchange resins to measure nitrogen mineralization and nitrification in intact soil cores. Commun. Soil Sci. Plant Anal. 17, 989-998. https://doi.org/10.1080/00103628609367767

Doherty, J., 2007. Users Manual for PEST Version 11. Watermark Numer. Comput., Brisbane, Queensl., Australia.

Dong, Z., Driscoll, C.T., Johnson, S.L., Campbell, J.L., Pourmokhtarian, A., Stoner, A.M.K., Hayhoe, K., 2019. Projections of water, carbon, and nitrogen dynamics under future climate change in an old-growth Douglas-fir forest in the western Cascade Range using a biogeochemical model. Sci. Total Environ. 656, 608-624. https://doi.org/10.1016/j.scitotenv.2018.11.377

Durán Zuazo, V.H., Martínez, J.R.F., Pleguezuelo, C.R.R., Martínez Raya, A., Rodríguez, B.C., 2006. Soil-erosion and runoff prevention by plant covers in a mountainous area (SE Spain): Implications for sustainable agriculture. Environmentalist 26, 309-319. https://doi.org/10.1007/s10669-006-0160-4

Eliades, M., Bruggeman, A., Lubczynski, M.W., Christou, A., Camera, C., Djuma, H., 2018. The water balance components of Mediterranean pine trees on a steep mountain slope during two hydrologically contrasting years. J. Hydrol. 562, 712-724. https://doi.org/10.1016/j.jhydrol.2018.05.048

Engelund, F., Hansen, E., 1972. A Monograph on Sediment Transport in Alluvial Streams, Technical University of Denmark, Hydraulic Laboratory. TEKNISKFORLAG Skelbrekgade 4 Copenhagen V, Denmark.

Fan, Y., Li, H., Miguez-Macho, G., 2013. Global patterns of groundwater table depth. Science (80-. ). 339, 940-943. https://doi.org/10.1126/science.1229881

Farquhar, G.D., von Caemmerer, S., Berry, J.A., 1980. A biochemical model of 
Exploring the possibilities of parsimonious nitrogen modelling in different ecosystems

photosynthetic CO2 assimilation in leaves of C3 species. Planta 149, 78-90. https://doi.org/10.1007/BF00386231

Fibbi, L., Moriondo, M., Chiesi, M., Bindi, M., Maselli, F., 2019. Impacts of climate change on the gross primary production of Italian forests. Ann. For. Sci. 76, 59. https://doi.org/10.1007/s13595-019-0843-x

Fierer, N., Schimel, J.P., Holden, P.A., 2003. Variations in microbial community composition through two soil depth profiles. Soil Biol. Biochem. 35, 167-176. https://doi.org/10.1016/S0038-0717(02)00251-1

Fontes, L., Bontemps, J.-D., Bugmann, H., Van Oijen, M., Gracia, C., Kramer, K., Lindner, M., Rötzer, T., Skovsgaard, J.P., 2010. Models for supporting forest management in a changing environment. For. Syst. 19, 8-29. https://doi.org/10.5424/fs/201019s-9315

Fowler, D., Coyle, M., Skiba, U., Sutton, M.A., Cape, J.N., Reis, S., Sheppard, L.J., Jenkins, A., Grizzetti, B., Galloway, J.N., Vitousek, P., Leach, A., Bouwman, A.F., Butterbach-Bahl, K., Dentener, F., Stevenson, D., Amann, M., Voss, M., 2013. The global nitrogen cycle in the Twentyfirst century. Philos. Trans. R. Soc. B Biol. Sci. 368, 13. https://doi.org/10.1098/rstb.2013.0164

Francés, F., Vélez, J.I., Vélez, J.J., 2007. Split-parameter structure for the automatic calibration of distributed hydrological models. J. Hydrol. 332, 226-240. https://doi.org/10.1016/J.JHYDROL.2006.06.032

Franko, U., Oelschlägel, B., Schenk, S., 1995. Simulation of temperature-, water- and nitrogen dynamics using the model CANDY. Ecol. Modell. 81, 213-222. https://doi.org/10.1016/0304-3800(94)00172-E

Gallardo, M., Giménez, C., Martínez-Gaitán, C., Stöckle, C.O., Thompson, R.B., Granados, M.R., 2011. Evaluation of the VegSyst model with muskmelon to simulate crop growth, nitrogen uptake and evapotranspiration. Agric. Water Manag. 101, 107-117. https://doi.org/10.1016/j.agwat.2011.09.008

Gallart, F., Llorens, P., Latron, J., Regüés, D., 2002. Hydrological processes and their seasonal controls in a small Mediterranean mountain catchment in the Pyrenees. Hydrol. Earth Syst. Sci. 6, 527-537. https://doi.org/10.5194/hess-6527-2002

Galloway, J.N., Dentener, F.J., Capone, D.G., Boyer, E.W., Howarth, R.W., Seitzinger, S.P., Asner, G.P., Cleveland, C.C., Green, P.A., Holland, E.A., Karl, D.M., Michaels, A.F., Porter, J.H., Townsend, A.R., Vörösmarty, C.J., 2004. Nitrogen 
Exploring the possibilities of parsimonious nitrogen modelling in different ecosystems cycles: Past, present, and future. Biogeochemistry 70, 153-226. https://doi.org/10.1007/s10533-004-0370-0

Galloway, J.N., Leach, A.M., Bleeker, A., Erisman, J.W., 2013. A chronology of human understanding of the nitrogen cycle. Philos. Trans. R. Soc. B Biol. Sci. 368, 20130120. https://doi.org/10.1098/rstb.2013.0120

Garcia-Ayllon, S., 2018. The Integrated Territorial Investment (ITI) of the Mar Menor as a model for the future in the comprehensive management of enclosed coastal seas. Ocean Coast. Manag. 166, 82-97. https://doi.org/10.1016/j.ocecoaman.2018.05.004

García-Ayllón, S., Miralles, J.L., 2014. The environmental impacts of land transformation in the coastal perimeter of the mar menor lagoon (SPAIN). Int. J. Des. Nat. Ecodynamics 9, 109-128. https://doi.org/10.2495/DNE-V9-N2-109128

García-Gómez, H., Garrido, J.L., Vivanco, M.G., Lassaletta, L., Rábago, I., Àvila, A., Tsyro, S., Sánchez, G., González Ortiz, A., González-Fernández, I., Alonso, R., 2014. Nitrogen deposition in Spain: Modeled patterns and threatened habitats within the Natura 2000 network. Sci. Total Environ. 485-486, 450-460. https://doi.org/10.1016/J.SCITOTENV.2014.03.112

García-Pintado, J., Martínez-Mena, M., Barberá, G.G., Albaladejo, J., Castillo, V.M., 2007. Anthropogenic nutrient sources and loads from a Mediterranean catchment into a coastal lagoon: Mar Menor, Spain. Sci. Total Environ. 373, 220-239. https://doi.org/10.1016/j.scitotenv.2006.10.046

Garcia-Prats, A., González-Sanchis, M., Del Campo, A.D., Lull, C., 2018. Hydrologyoriented forest management trade-offs. A modeling framework coupling field data, simulation results and Bayesian Networks. Sci. Total Environ. 639, 725741. https://doi.org/10.1016/j.scitotenv.2018.05.134

García-Ruiz, J.M., Beguería, S., Nadal-Romero, E., González-Hidalgo, J.C., LanaRenault, N., Sanjuán, Y., 2015. A meta-analysis of soil erosion rates across the world. Geomorphology 239, 160-173. https://doi.org/10.1016/j.geomorph.2015.03.008

García-Ruiz, J.M., López-Moreno, I.I., Vicente-Serrano, S.M., Lasanta-Martínez, T., Beguería, S., 2011. Mediterranean water resources in a global change scenario. Earth-Science Rev. https://doi.org/10.1016/j.earscirev.2011.01.006

Gazol, A., Sangüesa-Barreda, G., Granda, E., Camarero, J.J., 2017. Tracking the 
Exploring the possibilities of parsimonious nitrogen modelling in different ecosystems

impact of drought on functionally different woody plants in a Mediterranean scrubland ecosystem. Plant Ecol. 218, 1009-1020. https://doi.org/10.1007/s11258-017-0749-3

Giménez, C., Stöckle, C.O., Suárez-Rey, E.M., Gallardo, M., 2016. Crop yields and N losses tradeoffs in a garlic-wheat rotation in southern Spain. Eur. J. Agron. 73, 160-169. https://doi.org/10.1016/j.eja.2015.11.016

GIMHA, 2018. Description of the Distributed Conceptual Hydrological Model Tetis V.9.0.1. Research Group of Hydrological and Environmental Modelling, Universitat Politècnica de València, Valencia, Spain.

Giri, S., Nejadhashemi, A.P., 2014. Application of analytical hierarchy process for effective selection of agricultural best management practices. J. Environ. Manage. 132, 165-177. https://doi.org/10.1016/j.jenvman.2013.10.021

Giri, S., Nejadhashemi, A.P., Woznicki, S., Zhang, Z., 2014. Analysis of best management practice effectiveness and spatiotemporal variability based on different targeting strategies. Hydrol. Process. 28, 431-445. https://doi.org/10.1002/hyp.9577

Gleeson, D., Mathes, F., Farrell, M., Leopold, M., 2016. Environmental drivers of soil microbial community structure and function at the Avon River Critical Zone Observatory. Sci. Total Environ. 571, 1407-1418. https://doi.org/10.1016/J.SCITOTENV.2016.05.185

Golubyatnikov, L.L., Mokhov, I.I., Eliseev, A. V., 2013. Nitrogen cycle in the earth climatic system and its modeling. Izv. - Atmos. Ocean Phys. 49, 229-243. https://doi.org/10.1134/S0001433813030079

Granier, A., Loustau, D., Bréda, N., 2000. A generic model of forest canopy conductance dependent on climate, soil water availability and leaf area index. Ann. For. Sci. 57, 755-765. https://doi.org/10.1051/forest:2000158

Granlund, K., Rankinen, K., Etheridge, R., Seuri, P., Lehtoranta, J., 2015. Ecological recycling agriculture can reduce inorganic nitrogen losses - model results from three Finnish catchments. Agric. Syst. 133, 167-176. https://doi.org/10.1016/j.agsy.2014.10.015

Gruber, N., Galloway, J.N., 2008. An Earth-system perspective of the global nitrogen cycle. Nature 451, 293-296. https://doi.org/10.1038/nature06592

Guo, J., Zhou, J., Lu, J., Zou, Q., Zhang, H., Bi, S., 2014. Multi-objective optimization 
Exploring the possibilities of parsimonious nitrogen modelling in different ecosystems

of empirical hydrological model for streamflow prediction. J. Hydrol. 511, 242253. https://doi.org/10.1016/j.jhydrol.2014.01.047

Guo, J., Zhou, J., Zou, Q., Liu, Y., Song, L., 2013. A Novel Multi-Objective Shuffled Complex Differential Evolution Algorithm with Application to Hydrological Model Parameter Optimization. Water Resour. Manag. 27, 2923-2946. https://doi.org/10.1007/s11269-013-0324-1

Gutzler, C., Helming, K., Balla, D., Dannowski, R., Deumlich, D., Glemnitz, M., Knierim, A., Mirschel, W., Nendel, C., Paul, C., Sieber, S., Stachow, U., Starick, A., Wieland, R., Wurbs, A., Zander, P., 2015. Agricultural land use changes - A scenario-based sustainability impact assessment for Brandenburg, Germany. Ecol. Indic. 48, 505-517. https://doi.org/10.1016/j.ecolind.2014.09.004

Haas, M.B., Guse, B., Fohrer, N., 2017. Assessing the impacts of Best Management Practices on nitrate pollution in an agricultural dominated lowland catchment considering environmental protection versus economic development. J. Environ. Manage. 196, 347-364. https://doi.org/10.1016/j.jenvman.2017.02.060

Hanson, P.J., Edwards, N.T., Garten, C.T., Andrews, J.A., 2000. Separating root and soil microbial contributions to soil respiration: A review of methods and observations. Biogeochemistry 48, 115-146. https://doi.org/10.1023/A:1006244819642

Hargreaves, G.H., Samani, Z.A., 1985. Reference Crop Evapotranspiration from Temperature. Appl. Eng. Agric. 1, 96-99. https://doi.org/10.13031/2013.26773

Härkönen, S., Neumann, M., Mues, V., Berninger, F., Bronisz, K., Cardellini, G., Chirici, G., Hasenauer, H., Koehl, M., Lang, M., Merganicova, K., Mohren, F., Moiseyev, A., Moreno, A., Mura, M., Muys, B., Olschofsky, K., Del Perugia, B., Rørstad, P.K., Solberg, B., Thivolle-Cazat, A., Trotsiuk, V., Mäkelä, A., 2019. A climate-sensitive forest model for assessing impacts of forest management in Europe. Environ. Model. Softw. 115, 128-143. https://doi.org/10.1016/j.envsoft.2019.02.009

Harrison, S., McAree, C., Mulville, W., Sullivan, T., 2019. The problem of agricultural 'diffuse' pollution: Getting to the point. Sci. Total Environ. 677, 700-717. https://doi.org/10.1016/J.SCITOTENV.2019.04.169

Hashemi, F., Olesen, J.E., Dalgaard, T., Børgesen, C.D., 2016. Review of scenario analyses to reduce agricultural nitrogen and phosphorus loading to the aquatic environment. Sci. Total Environ. 573, 608-626. 
Exploring the possibilities of parsimonious nitrogen modelling in different ecosystems

https://doi.org/10.1016/j.scitotenv.2016.08.141

Hassan, S.M.M.T., Lubczynski, M.W., Niswonger, R.G., Su, Z., 2014. Surfacegroundwater interactions in hard rocks in Sardon Catchment of western Spain: An integrated modeling approach. J. Hydrol. 517, 390-410. https://doi.org/10.1016/j.jhydrol.2014.05.026

He, J., Dukes, M.D., Hochmuth, G.J., Jones, J.W., Graham, W.D., 2012. Identifying irrigation and nitrogen best management practices for sweet corn production on sandy soils using CERES-Maize model. Agric. Water Manag. 109, 61-70. https://doi.org/10.1016/j.agwat.2012.02.007

He, R., Yang, X., Gassman, P.W., Wang, G., Yu, C., 2019. Spatiotemporal characterization of nutrient pollution source compositions in the Xiaohong River Basin, China. Ecol. Indic. 107, 12. https://doi.org/10.1016/J.ECOLIND.2019.105676

Herman, M.R., Nejadhashemi, A.P., Abouali, M., Hernandez-Suarez, J.S., Daneshvar, F., Zhang, Z., Anderson, M.C., Sadeghi, A.M., Hain, C.R., Sharifi, A., 2018. Evaluating the role of evapotranspiration remote sensing data in improving hydrological modeling predictability. J. Hydrol. 556, 39-49. https://doi.org/10.1016/j.jhydrol.2017.11.009

Herrera, S., Fernández, J., Gutiérrez, J.M., 2016. Update of the Spain02 gridded observational dataset for EURO-CORDEX evaluation: Assessing the effect of the interpolation methodology. Int. J. Climatol. 36, 900-908. https://doi.org/10.1002/joc.4391

Hidy, D., Barcza, Z., Marjanović, H., Ostrogović Sever, M.Z., Dobor, L., Gelybó, G., Fodor, N., Pintér, K., Churkina, G., Running, S., Thornton, P., Bellocchi, G., Haszpra, L., Horváth, F., Suyker, A., Nagy, Z., 2016. Terrestrial ecosystem process model Biome-BGCMuSo v4.0: summary of improvements and new modeling possibilities. Geosci. Model Dev. 9, 4405-4437. https://doi.org/10.5194/gmd-9-4405-2016

Hiederer, R., 2013. Mapping Soil Properties for Europe - Spatial Representation of Soil Database Attributes, JRC Technical Reports. Luxembourg: Publications Office of the European Union. https://doi.org/10.2788/94128

Himanshu, S.K., Pandey, A., Yadav, B., Gupta, A., 2019. Evaluation of best management practices for sediment and nutrient loss control using SWAT model. Soil Tillage Res. 192, 42-58. https://doi.org/10.1016/j.still.2019.04.016 
Exploring the possibilities of parsimonious nitrogen modelling in different ecosystems

Hubbert, K.R., Graham, R.C., Anderson, M.A., 2001. Soil and weathered bedrock: Components of a Jeffrey pine plantation substrate. Soil Sci. Soc. Am. J. 65, 12551262. https://doi.org/10.2136/sssaj2001.6541255x

Hutson, J.L., 2003. LEACHM - Leaching Estimation and Chemistry Model. Department of Crop and Soil Sciences, Cornell University, Ithaca, New York, Ithaca, New York.

Ingram, J., 2008. Agronomist-farmer knowledge encounters: An analysis of knowledge exchange in the context of best management practices in England. Agric. Human Values 25, 405-418. https://doi.org/10.1007/s10460-008-9134-0

Jabloun, M., Li, X., Zhang, X., Tao, F., Hu, C., Olesen, J.E., 2018. Sensitivity of simulated crop yield and nitrate leaching of the wheat-maize cropping system in the North China Plain to model parameters. Agric. For. Meteorol. 263, 2540. https://doi.org/10.1016/j.agrformet.2018.08.002

Jang, S.S., Ahn, S.R., Kim, S.J., 2017. Evaluation of executable best management practices in Haean highland agricultural catchment of South Korea using SWAT. Agric. Water Manag. 180, 224-234. https://doi.org/10.1016/j.agwat.2016.06.008

Jenkinson, D.S., Andrew, S.P.S., Lynch, J.M., Goss, M.J., Tinker, P.B., 1990. The turnover of organic carbon and nitrogen in soil. Philos. Trans. R. Soc. London. Ser. B Biol. Sci. 329, 361-368. https://doi.org/10.1098/rstb.1990.0177

Jiménez-Martínez, J., García-Aróstegui, J.L., Hunink, J.E., Contreras, S., Baudron, P., Candela, L., 2016. The role of groundwater in highly human-modified hydrosystems: a review of impacts and mitigation options in the Campo de Cartagena-Mar Menor coastal plain (SE Spain). Environ. Rev. 24, 377-392. https://doi.org/10.1139/er-2015-0089

Jin, L., Whitehead, P.G., Futter, M.N., Lu, Z., 2012. Modelling the impacts of climate change on flow and nitrate in the River Thames: assessing potential adaptation strategies. Hydrol. Res. 43, 902-916. https://doi.org/10.2166/nh.2011.080

Jin, L., Whitehead, P.G., Heppell, C.M., Lansdown, K., Purdie, D.A., Trimmer, M., 2016. Modelling flow and inorganic nitrogen dynamics on the Hampshire Avon: Linking upstream processes to downstream water quality. Sci. Total Environ. 572, 1496-1506. https://doi.org/10.1016/j.scitotenv.2016.02.156

Jin, W., He, H.S., Thompson, F.R., 2016. Are more complex physiological models of forest ecosystems better choices for plot and regional predictions? Environ. 
Exploring the possibilities of parsimonious nitrogen modelling in different ecosystems

Model. Softw. 75, 1-14. https://doi.org/10.1016/j.envsoft.2015.10.004

Julien, P.Y., 2010. Erosion and sedimentation, 2nd ed. Cambridge University Press.

Jung, Y.W., Oh, D.S., Kim, M., Park, J.W., 2010. Calibration of LEACHN model using LH-OAT sensitivity analysis. Nutr. Cycl. Agroecosystems 87, 261-275. https://doi.org/10.1007/s10705-009-9337-9

Kätterer, T., Andrén, O., 2001. The ICBM family of analytically solved models of soil carbon, nitrogen and microbial biomass dynamics - descriptions and application examples. Ecol. Modell. 136, 191-207. https://doi.org/10.1016/S0304-3800(00)00420-8

Kersebaum, K.C., Boote, K.J., Jorgenson, J.S., Nendel, C., Bindi, M., Frühauf, C., Gaiser, T., Hoogenboom, G., Kollas, C., Olesen, J.E., Rötter, R.P., Ruget, F., Thorburn, P.J., Trnka, M., Wegehenkel, M., 2015. Analysis and classification of data sets for calibration and validation of agro-ecosystem models. Environ. Model. Softw. 72, 402-417. https://doi.org/10.1016/j.envsoft.2015.05.009

Kilinc, M., Richardson, E. V, 1973. Mechanics of Soil Erosion from Overland Flow Generated by Simulated Rainfall. Colorado State University. Hydrology Papers.

Kimmins, J.P., 2004. Forest ecology: a foundation for sustainable forest management and environmental ethics in forestry, 3rd ed. Upper Saddle River, New Jersey: Prentice-Hall.

Kollas, C., Kersebaum, K.C., Nendel, C., Manevski, K., Müller, C., Palosuo, T., Armas-Herrera, C.M., Beaudoin, N., Bindi, M., Charfeddine, M., Conradt, T., Constantin, J., Eitzinger, J., Ewert, F., Ferrise, R., Gaiser, T., Cortazar-Atauri, I.G. de, Giglio, L., Hlavinka, P., Hoffmann, H., Hoffmann, M.P., Launay, M., Manderscheid, R., Mary, B., Mirschel, W., Moriondo, M., Olesen, J.E., Öztürk, I., Pacholski, A., Ripoche-Wachter, D., Roggero, P.P., Roncossek, S., Rötter, R.P., Ruget, F., Sharif, B., Trnka, M., Ventrella, D., Waha, K., Wegehenkel, M., Weigel, H.J., Wu, L., 2015. Crop rotation modelling-A European model intercomparison. Eur. J. Agron. 70, 98-111. https://doi.org/10.1016/j.eja.2015.06.007

Kozlowski, T.T., 2002. Physiological ecology of natural regeneration of harvested and disturbed forest stands: Implications for forest management. For. Ecol. Manage. 158, 195-221. https://doi.org/10.1016/S0378-1127(00)00712-X

La Nauze, A., Mezzetti, C., 2019. Dynamic incentive regulation of diffuse pollution. 
Exploring the possibilities of parsimonious nitrogen modelling in different ecosystems
J. Environ.
Econ.
Manage.
93,
$101-124$

https://doi.org/10.1016/j.jeem.2018.11.009

Lado-Monserrat, L., Lull, C., Bautista, I., Lidón, A., Herrera, R., 2014. Soil moisture increment as a controlling variable of the "Birch effect". Interactions with the pre-wetting soil moisture and litter addition. Plant Soil 379, 21-34. https://doi.org/10.1007/s11104-014-2037-5

Lam, Q.D., Schmalz, B., Fohrer, N., 2011. The impact of agricultural Best Management Practices on water quality in a North German lowland catchment. Environ. Monit. Assess. 183, 351-379. https://doi.org/10.1007/s10661-011-1926-9

Lamers, M., Ingwersen, J., Streck, T., 2007. Modelling N2O emission from a forest upland soil: A procedure for an automatic calibration of the biogeochemical model Forest-DNDC. Ecol. Modell. 205, 52-58. https://doi.org/10.1016/j.ecolmodel.2007.02.007

Landsberg, J., 2003. Modelling forest ecosystems: state of the art, challenges, and future directions. Can. J. For. Res. 33, 385-397. https://doi.org/10.1139/x02-129

Lardy, R., Bellocchi, G., Soussana, J.F., 2011. A new method to determine soil organic carbon equilibrium. Environ. Model. Softw. 26, 1759-1763. https://doi.org/10.1016/j.envsoft.2011.05.016

Le Moal, M., Gascuel-Odoux, C., Ménesguen, A., Souchon, Y., Étrillard, C., Levain, A., Moatar, F., Pannard, A., Souchu, P., Lefebvre, A., Pinay, G., 2019. Eutrophication: A new wine in an old bottle? Sci. Total Environ. https://doi.org/10.1016/j.scitotenv.2018.09.139

León, V.M., Moreno-González, R., García, V., Campillo, J.A., 2017. Impact of flash flood events on the distribution of organic pollutants in surface sediments from a Mediterranean coastal lagoon (Mar Menor, SE Spain). Environ. Sci. Pollut. Res. 24, 4284-4300. https://doi.org/10.1007/s11356-015-4628-y

Li, C., Aber, J., Stange, F., Butterbach-Bahl, K., Papen, H., 2000. A process-oriented model of $\mathrm{N} 2 \mathrm{O}$ and $\mathrm{NO}$ emissions from forest soils: 1. Model development. J. Geophys. Res. Atmos. 105, 4369-4384. https://doi.org/10.1029/1999JD900949

Li, X., Gentine, P., Lin, C., Zhou, S., Sun, Z., Zheng, Y., Liu, J., Zheng, C., 2019. A simple and objective method to partition evapotranspiration into transpiration and evaporation at eddy-covariance sites. Agric. For. Meteorol. 265, 171-182. https://doi.org/10.1016/j.agrformet.2018.11.017 
Exploring the possibilities of parsimonious nitrogen modelling in different ecosystems

Lidón, A., Ramos, C., Ginestar, D., Contreras, W., 2013. Assessment of LEACHN and a simple compartmental model to simulate nitrogen dynamics in citrus orchards. Hater Manag. 121, 42-53. https://doi.org/10.1016/j.agwat.2013.01.008

Lidón, A., Ramos, C., Rodrigo, A., 1999. Comparison of drainage estimation methods in irrigated citrus orchards. Irrig. Sci. 19, 25-36. https://doi.org/10.1007/s002710050068

Limousin, J.M., Rambal, S., Ourcival, J.M., Rocheteau, A., Joffre, R., RodriguezCortina, R., 2009. Long-term transpiration change with rainfall decline in a Mediterranean Quercus ilex forest. Glob. Chang. Biol. 15, 2163-2175. https://doi.org/10.1111/j.1365-2486.2009.01852.x

Lin, B. Le, Sakoda, A., Shibasaki, R., Suzuki, M., 2001. A modelling approach to global nitrate leaching caused by anthropogenic fertilisation. Water Res. 35, 1961-1968. https://doi.org/10.1016/S0043-1354(00)00484-X

Liu, R., Zhang, P., Wang, X., Chen, Y., Shen, Z., 2013. Assessment of effects of best management practices on agricultural non-point source pollution in Xiangxi River watershed. Agric. Water Manag. 117, 9-18. https://doi.org/10.1016/j.agwat.2012.10.018

López-Ballesteros, A., Senent-Aparicio, J., Srinivasan, R., Pérez-Sánchez, J., 2019. Assessing the impact of best management practices in a highly anthropogenic and ungauged watershed using the SWAT model: A case study in the El beal

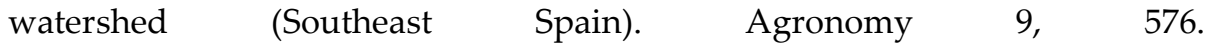
https://doi.org/10.3390/agronomy9100576

Lozano-García, B., Parras-Alcántara, L., Brevik, E.C., 2016. Impact of topographic aspect and vegetation (native and reforested areas) on soil organic carbon and nitrogen budgets in Mediterranean natural areas. Sci. Total Environ. 544, 963970. https://doi.org/10.1016/j.scitotenv.2015.12.022

Lü, X.-T., Liu, Z.-Y., Hu, Y.-Y., Zhang, H.-Y., 2018. Testing nitrogen and water colimitation of primary productivity in a temperate steppe. Plant Soil 432, 119127. https://doi.org/10.1007/s11104-018-3791-6

Lubczynski, M.W., 2009. The hydrogeological role of trees in water-limited environments. Hydrogeol. J. 17, 247-259. https://doi.org/10.1007/s10040-0080357-3

Lucas-Borja, M.E., Hedo de Santiago, J., Yang, Y., Shen, Y., Candel-Pérez, D., 2019. 
Exploring the possibilities of parsimonious nitrogen modelling in different ecosystems

Nutrient, metal contents and microbiological properties of litter and soil along a tree age gradient in Mediterranean forest ecosystems. Sci. Total Environ. 650, 749-758. https://doi.org/10.1016/j.scitotenv.2018.09.079

Lupon, A., Gerber, S., Sabater, F., Bernal, S., 2015. Climate response of the soil nitrogen cycle in three forest types of a headwater Mediterranean catchment. J. Geophys. Res. Biogeosciences 120, 859-875. https://doi.org/10.1002/2014JG002791

Macfarlane, C., Grigg, A., McGregor, R., Ogden, G., Silberstein, R., 2018. Overstorey evapotranspiration in a seasonally dry Mediterranean eucalypt forest: Response to groundwater and mining. Ecohydrology 11, 17. https://doi.org/10.1002/eco.1971

Manevski, K., Børgesen, C.D., Andersen, M.N., Kristensen, I.S., 2015. Reduced nitrogen leaching by intercropping maize with red fescue on sandy soils in North Europe: a combined field and modeling study. Plant Soil 388, 67-85. https://doi.org/10.1007/s11104-014-2311-6

Manzoni, S., Porporato, A., 2007. A theoretical analysis of nonlinearities and feedbacks in soil carbon and nitrogen cycles. Soil Biol. Biochem. 39, 1542-1556. https://doi.org/10.1016/j.soilbio.2007.01.006

Manzoni, S., Porporato, A., D’Odorico, P., Laio, F., Rodriguez-Iturbe, I., 2004. Soil nutrient cycles as a nonlinear dynamical system. Nonlinear Process. Geophys. 11, 589-598. https://doi.org/10.5194/npg-11-589-2004

Martens, B., Miralles, D.G., Lievens, H., Van Der Schalie, R., De Jeu, R.A.M., Fernández-Prieto, D., Beck, H.E., Dorigo, W.A., Verhoest, N.E.C., 2017. GLEAM v3: Satellite-based land evaporation and root-zone soil moisture. Geosci. Model Dev. 10, 1903-1925. https://doi.org/10.5194/gmd-10-1903-2017

Medici, C., 2010. Progressive development of a hydrologic and inorganic nitrogen conceptual model to improve the understanding of small Mediterranean catchments behaviour. Thesis. Universitat Politècnica de València.

Medici, C., Butturini, A., Bernal, S., Vázquez, E., Sabater, F., Vélez, J.I., Francés, F., 2008. Modelling the non-linear hydrological behaviour of a small Mediterranean forested catchment. Hydrol. Process. 22, 3814-3828. https://doi.org/10.1002/hyp.6991

Medici, C., Wade, A.J., Francés, F., 2012. Does increased hydrochemical model complexity decrease robustness? J. Hydrol. 440-441, 1-13. 
Exploring the possibilities of parsimonious nitrogen modelling in different ecosystems

https://doi.org/10.1016/j.jhydrol.2012.02.047

Merchán, D., Casalí, J., Del Valle de Lersundi, J., Campo-Bescós, M.A., Giménez, R., Preciado, B., Lafarga, A., 2018. Runoff, nutrients, sediment and salt yields in an irrigated watershed in southern Navarre (Spain). Agric. Water Manag. 195, 120-132. https://doi.org/10.1016/j.agwat.2017.10.004

Mertens, J., Madsen, H., Kristensen, M., Jacques, D., Feyen, J., 2005. Sensitivity of soil parameters in unsaturated zone modelling and the relation between effective, laboratory and in situ estimates. Hydrol. Process. 19, 1611-1633. https://doi.org/10.1002/hyp.5591

Miehle, P., Livesley, S.J., Feikema, P.M., Li, C., Arndt, S.K., 2006. Assessing productivity and carbon sequestration capacity of Eucalyptus globulus plantations using the process model Forest-DNDC: Calibration and validation. Ecol. Modell. 192, 83-94. https://doi.org/10.1016/j.ecolmodel.2005.07.021

Miller, G.R., Chen, X., Rubin, Y., Ma, S., Baldocchi, D.D., 2010. Groundwater uptake by woody vegetation in a semiarid oak savanna. Water Resour. Res. 46. https://doi.org/10.1029/2009WR008902

Mintegui, J.Á., de Simón, E., García-Rodríguez, J.L., Robredo, J.C., 1993. La restauración hidrológico-forestal en las ceuncas hidrográficas de la vertiente mediterránea. Junta de Andalucía. Consejería de Agricultura y Pesca.

Miralles, D.G., Holmes, T.R.H., De Jeu, R.A.M., Gash, J.H., Meesters, A.G.C.A., Dolman, A.J., 2011. Global land-surface evaporation estimated from satellitebased observations. Hydrol. Earth Syst. Sci. 15, 453-469. https://doi.org/10.5194/hess-15-453-2011

Mittal, S.B., Anlauf, R., Laik, R., Gupta, A.P., Kapoor, A.K., Dahiya, S.S., 2007. Modeling nitrate leaching and organic-C build-up under semi-arid cropping conditions of $\mathrm{N}$ India. J. Plant Nutr. Soil Sci. 170, 506-513. https://doi.org/10.1002/jpln.200521725

Moriasi, D.N., Arnold, J.G., Van Liew, M.W., Bingner, R.L., Harmel, R.D., Veith, T.L., 2007. Model Evaluation Guidelines for Systematic Quantification of Accuracy in Watershed Simulations. Trans. ASABE 50, 885-900. https://doi.org/10.13031/2013.23153

Morillas, L., Leuning, R., Villagarcía, L., García, M., Serrano-Ortiz, P., Domingo, F., 2013. Improving evapotranspiration estimates in Mediterranean drylands: The role of soil evaporation. Water Resour. Res. 49, 6572-6586. 
Exploring the possibilities of parsimonious nitrogen modelling in different ecosystems https://doi.org/10.1002/wrcr.20468

Mtibaa, S., Hotta, N., Irie, M., 2018. Analysis of the efficacy and cost-effectiveness of best management practices for controlling sediment yield: A case study of the Joumine watershed, Tunisia. Sci. Total Environ. 616-617, 1-16. https://doi.org/10.1016/j.scitotenv.2017.10.290

Nash, J.E., Sutcliffe, J. V., 1970. River flow forecasting through conceptual models part I - A discussion of principles. J. Hydrol. 10, 282-290. https://doi.org/10.1016/0022-1694(70)90255-6

Nasri, N., Chebil, M., Guellouz, L., Bouhlila, R., Maslouhi, A., Ibnoussina, M., 2015. Modelling nonpoint source pollution by nitrate of soil in the Mateur plain, northeast of Tunisia. Arab. J. Geosci. 8, 1057-1075. https://doi.org/10.1007/s12517-013-1215-8

Neal, C., Jarvie, H.P., Wade, A.J., Whitehead, P.G., 2002. Water quality functioning of lowland permeable catchments: Inferences from an intensive study of the River Kennet and upper River Thames. Sci. Total Environ. 282-283, 471-490. https://doi.org/10.1016/S0048-9697(01)00930-5

Nendel, C., Berg, M., Kersebaum, K.C., Mirschel, W., Specka, X., Wegehenkel, M., Wenkel, K.O., Wieland, R., 2011. The MONICA model: Testing predictability for crop growth, soil moisture and nitrogen dynamics. Ecol. Modell. 222, 16141625. https://doi.org/10.1016/j.ecolmodel.2011.02.018

Newman, G.S., Arthur, M.A., Muller, R.N., 2006. Above- and belowground net primary production in a temperate mixed deciduous forest. Ecosystems 9, 317329. https://doi.org/10.1007/s10021-006-0015-3

Nimah, M.N., Hanks, R.J., 1973. Model for Estimating Soil Water, Plant, and Atmospheric Interrelations: I. Description and Sensitivity. Soil Sci. Soc. Am. J. 37, 522-527. https://doi.org/10.2136/sssaj1973.03615995003700040018x

Norman, J., Jansson, P.E., Farahbakhshazad, N., Butterbach-Bahl, K., Li, C., Klemedtsson, L., 2008. Simulation of NO and N2O emissions from a spruce forest during a freeze/thaw event using an N-flux submodel from the PnET-NDNDC model integrated to CoupModel. Ecol. Modell. 216, 18-30. https://doi.org/10.1016/j.ecolmodel.2008.04.012

Özcan, Z., Başkan, O., Düzgün, H.Ş., Kentel, E., Alp, E., 2017a. A pollution fate and transport model application in a semi-arid region: Is some number better than no number? Sci. Total Environ. 595, 425-440. 
Exploring the possibilities of parsimonious nitrogen modelling in different ecosystems

https://doi.org/10.1016/j.scitotenv.2017.03.240

Özcan, Z., Kentel, E., Alp, E., 2017b. Evaluation of the best management practices in a semi-arid region with high agricultural activity. Agric. Water Manag. 194, 160-171. https://doi.org/10.1016/j.agwat.2017.09.007

Panagos, P., Borrelli, P., Meusburger, K., van der Zanden, E.H., Poesen, J., Alewell, C., 2015. Modelling the effect of support practices (P-factor) on the reduction of soil erosion by water at European scale. Environ. Sci. Policy 51, 23-34. https://doi.org/10.1016/j.envsci.2015.03.012

Panagos, P., Meusburger, K., Ballabio, C., Borrelli, P., Alewell, C., 2014. Soil erodibility in Europe: A high-resolution dataset based on LUCAS. Sci. Total Environ. 479-480, 189-200. https://doi.org/10.1016/j.scitotenv.2014.02.010

Pardo, G., del Prado, A., Martínez-Mena, M., Bustamante, M.A., Martín, J.A.A.R., Álvaro-Fuentes, J., Moral, R., 2017. Orchard and horticulture systems in Spanish Mediterranean coastal areas: Is there a real possibility to contribute to C sequestration? Agric. Ecosyst. Environ. 238, 153-167. https://doi.org/10.1016/j.agee.2016.09.034

Pärn, J., Pinay, G., Mander, Ü., 2012. Indicators of nutrients transport from agricultural catchments under temperate climate: A review. Ecol. Indic. 22, 415. https://doi.org/10.1016/j.ecolind.2011.10.002

Pasquato, M., Medici, C., Friend, A.D., Francés, F., 2015. Comparing two approaches for parsimonious vegetation modelling in semiarid regions using satellite data. Ecohydrology 8, 1024-1036. https://doi.org/10.1002/eco.1559

Pastor, J., Post, W.M., 1986. Influence of climate, soil moisture, and succession on forest carbon and nitrogen cycles. Biogeochemistry 2, 3-27. https://doi.org/10.1007/BF02186962

Pathak, D., Whitehead, P.G., Futter, M.N., Sinha, R., 2018. Water quality assessment and catchment-scale nutrient flux modeling in the Ramganga River Basin in north India: An application of INCA model. Sci. Total Environ. 631-632, 201215. https://doi.org/10.1016/j.scitotenv.2018.03.022

Pearce, N.J.T., Yates, A.G., 2017. Intra-annual variation of the association between agricultural best management practices and stream nutrient concentrations. Sci. Total Environ. 586, 1124-1134. https://doi.org/10.1016/j.scitotenv.2017.02.102 
Exploring the possibilities of parsimonious nitrogen modelling in different ecosystems

Perni, A., Martínez-Paz, J.M., 2013. A participatory approach for selecting costeffective measures in the WFD context: The Mar Menor (SE Spain). Sci. Total Environ. 458-460, 303-311. https://doi.org/10.1016/j.scitotenv.2013.04.029

Piñol, J., Lledó, M.J., Escarré, A., 1991. Hydrological balance of two Mediterranean forested catchments (Prades, northeast Spain). Hydrol. Sci. J. 36, 95-107. https://doi.org/10.1080/02626669109492492

Poch-Massegú, R., Jiménez-Martínez, J., Wallis, K.J., Ramírez de Cartagena, F., Candela, L., 2014. Irrigation return flow and nitrate leaching under different crops and irrigation methods in Western Mediterranean weather conditions. Agric. Water Manag. 134, 1-13. https://doi.org/10.1016/j.agwat.2013.11.017

Porporato, A., D'Odorico, P., Laio, F., Rodriguez-Iturbe, I., 2003. Hydrologic controls on soil carbon and nitrogen cycles. I. Modeling scheme. Adv. Water Resour. 26, 45-58. https://doi.org/10.1016/S0309-1708(02)00094-5

Porporato, A., Feng, X., Manzoni, S., Mau, Y., Parolari, A.J., Vico, G., 2015. Ecohydrological modeling in agroecosystems: Examples and challenges. Water Resour. Res. 51, 5081-5099. https://doi.org/10.1002/2015WR017289

Porporato, A., Laio, F., Ridolfi, L., Rodriguez-Iturbe, I., 2001. Plants in watercontrolled ecosystems: active role in hydrologic processes and response to water stress III. Vegetation water stress. Adv. Water Resour. 24, 725-744. https://doi.org/10.1016/S0309-1708(01)00006-9

Pradhan, P., Fischer, G., Van Velthuizen, H., Reusser, D.E., Kropp, J.P., 2015. Closing yield gaps: How sustainable can we be? PLoS One 10, 18. https://doi.org/10.1371/journal.pone.0129487

Puertes, C., Lidón, A., Echeverría, C., Bautista, I., González-Sanchis, M., del Campo, A.D., Francés, F., 2019. Explaining the hydrological behaviour of facultative phreatophytes using a multi-variable and multi-objective modelling approach. J. Hydrol. 575, 395-407. https://doi.org/10.1016/j.jhydrol.2019.05.041

Qiu, J., Shen, Z., Huang, M., Zhang, X., 2018. Exploring effective best management practices in the Miyun reservoir watershed, China. Ecol. Eng. 123, 30-42. https://doi.org/10.1016/j.ecoleng.2018.08.020

Quemada, M., Baranski, M., Nobel-de Lange, M.N.J., Vallejo, A., Cooper, J.M., 2013. Meta-analysis of strategies to control nitrate leaching in irrigated agricultural systems and their effects on crop yield. Agric. Ecosyst. Environ. 174, 1-10. https://doi.org/10.1016/j.agee.2013.04.018 
Exploring the possibilities of parsimonious nitrogen modelling in different ecosystems

Rahn, C.R., Zhang, K., Lillywhite, R., Ramos, C., Doltra, J., de Paz, J.M., Riley, H., Fink, M., Nendel, C., Thorup-Kristensen, K., Pedersen, A., Piro, F., Venezia, A., Firth, C., Schmutz, U., Rayns, F., Strohmeyer, K., 2010. Eu-Rotate_N - a decision support system - to predict environmental and economic consequences of the management of nitrogen fertiliser in crop rotations. Eur. J. Hortic. Sci. 75, 2032.

Ramos, C., Carbonell, E.A., 1991. Nitrate leaching and soil moisture prediction with the LEACHM model. Fertil. Res. 27, 171-180. https://doi.org/10.1007/BF01051125

Ramos, C., Pomares, F., 2010. Abonado de los cultivos hortícolas, in: Guía Práctica de La Fertilización Racional de Los Cultivos En España. Ministerio de Medio Ambiente y Medio Rural y Marino, p. 260.

Randall, G.W., Mulla, D.J., 2001. Nitrate Nitrogen in Surface Waters as Influenced by Climatic Conditions and Agricultural Practices. J. Environ. Qual. 30, 337344. https://doi.org/10.2134/jeq2001.302337x

Rankinen, K., Karvonen, T., Butterfield, D., 2006. An application of the GLUE methodology for estimating the parameters of the INCA-N model. Sci. Total Environ. 365, 123-139. https://doi.org/10.1016/J.SCITOTENV.2006.02.034

Rao, N.S., Easton, Z.M., Schneiderman, E.M., Zion, M.S., Lee, D.R., Steenhuis, T.S., 2009. Modeling watershed-scale effectiveness of agricultural best management practices to reduce phosphorus loading. J. Environ. Manage. 90, 1385-1395. https://doi.org/10.1016/j.jenvman.2008.08.011

Rasmussen, S.B., Blenkinsop, S., Burton, A., Abrahamsen, P., Holm, P.E., Hansen, S., 2018. Climate change impacts on agro-climatic indices derived from downscaled weather generator scenarios for eastern Denmark. Eur. J. Agron. 101, 222-238. https://doi.org/10.1016/j.eja.2018.04.004

Rey Benayas, J.M., Viñegla Prades, F., Mesa Fraile, A. V., 2017. Diseño de una red de setos e islotes forestales para la restauración agroecológica de la Cuenca Sur del Mar Menor (Murcia). Fundación Internacional para la Restauración de Ecosistemas, Madrid. Consejería de Agua, Agricultura y Medio Ambiente, Región de Murcia.

Rey, J., Martínez, J., Barberá, G.G., García-Aróstegui, J.L., García-Pintado, J., Martínez-Vicente, D., 2013. Geophysical characterization of the complex dynamics of groundwater and seawater exchange in a highly stressed aquifer 
Exploring the possibilities of parsimonious nitrogen modelling in different ecosystems

system linked to a coastal lagoon (SE Spain). Environ. Earth Sci. 70, 2271-2282. https://doi.org/10.1007/s12665-013-2472-2

Reyes-Acosta, J.L., Lubczynski, M.W., 2013. Mapping dry-season tree transpiration of an oak woodland at the catchment scale, using object-attributes derived from satellite imagery and sap flow measurements. Agric. For. Meteorol. 174175, 184-201. https://doi.org/10.1016/j.agrformet.2013.02.012

Rincon, L., Saez, J., Perez, J., Pellicer, C., Gomez, M., 1999. Crecimiento y Absorción de Nutrientes del Brócoli. Invest. Agr. Prod. Prot. Veg. 14, 225-236.

Rodrigo, A., Recous, S., Neel, C., Mary, B., 1997. Modelling temperature and moisture effects on C-N transformations in soils: Comparison of nine models. Ecol. Modell. 102, 325-339. https://doi.org/10.1016/S0304-3800(97)00067-7

Rodriguez-Iturbe, I., Porporato, A., Laio, F., Ridolfi, L., 2001. Plants in watercontrolled ecosystems: active role in hydrologic processes and response to water stress I. Scope and general outline. Adv. Water Resour. 24, 695-705. https://doi.org/10.1016/S0309-1708(01)00004-5

Ruiz-Pérez, G., González-Sanchis, M., Del Campo, A.D., Francés, F., 2016a. Can a parsimonious model implemented with satellite data be used for modelling the vegetation dynamics and water cycle in water-controlled environments? Ecol. Modell. 324, 45-53. https://doi.org/10.1016/j.ecolmodel.2016.01.002

Ruiz-Pérez, G., Medici, C., Latron, J., Llorens, P., Gallart, F., Francés, F., 2016b. Investigating the behaviour of a small Mediterranean catchment using three different hydrological models as hypotheses. Hydrol. Process. 30, 2050-2062. https://doi.org/10.1002/hyp.10738

Running, S.W., Gower, S.T., 1991. FOREST-BGC, A general model of forest ecosystem processes for regional applications. II. Dynamic carbon allocation and nitrogen budgets. Tree Physiol. 9, 147-160. https://doi.org/10.1093/treephys/9.1-2.147

Salazar, O., Nájera, F., Tapia, W., Casanova, M., 2017. Evaluation of the DAISY model for predicting nitrogen leaching in coarse-textured soils cropped with maize in the Mediterranean zone of Chile. Agric. Water Manag. 182, 77-86. https://doi.org/10.1016/j.agwat.2016.12.005

Salo, T.J., Palosuo, T., Kersebaum, K.C., Nendel, C., Angulo, C., Ewert, F., Bindi, M., Calanca, P., Klein, T., Moriondo, M., Ferrise, R., Olesen, J.E., Patil, R.H., Ruget, F., Takáč, J., Hlavinka, P., Trnka, M., Rötter, R.P., 2016. Comparing the 
Exploring the possibilities of parsimonious nitrogen modelling in different ecosystems

performance of 11 crop simulation models in predicting yield response to nitrogen fertilization. J. Agric. Sci. 154, 1218-1240. https://doi.org/10.1017/S0021859615001124

Sardans, J., Peñuelas, J., 2013. Plant-soil interactions in Mediterranean forest and shrublands: Impacts of climatic change. Plant Soil 365, 1-33. https://doi.org/10.1007/s11104-013-1591-6

Sardans, J., Peñuelas, J., Ogaya, R., 2008. Drought-induced changes in C and N stoichiometry in a Quercus ilex Mediterranean forest. For. Sci. 54, 513-522. https://doi.org/10.1093/forestscience/54.5.513

Sardans, J., Rodà, F., 2004. Phosphorus Limitation and Competitive Capacities of Pinus halepensis and Quercus ilex subsp. rotundifolia on Different Soils. Plant Ecol. 174, 305-317. https://doi.org/10.1023/B:VEGE.0000049110.88127.a0

Saxton, K.E., Rawls, W.J., 2006. Soil Water Characteristic Estimates by Texture and Organic Matter for Hydrologic Solutions. Soil Sci. Soc. Am. J. 70, 1569-1578. https://doi.org/10.2136/sssaj2005.0117

Schlesinger, W.H., Reckhow, K.H., Bernhardt, E.S., 2006. Global change: The nitrogen cycle and rivers. Water Resour. Res. 42. https://doi.org/10.1029/2005WR004300

Schmied, B., Abbaspour, K., Schulin, R., 2000. Inverse Estimation of Parameters in a Nitrogen Model Using Field Data. Soil Sci. Soc. Am. J. 64, 533-542. https://doi.org/10.2136/sssaj2000.642533x

Schwinning, S., 2010. The ecohydrology of roots in rocks. Ecohydrology 3, 238-245. https://doi.org/10.1002/eco.134

Sever, M.Z.O., Paladinić, E., Barcza, Z., Hidy, D., Kern, A., Anić, M., Marjanović, H., 2017. Biogeochemical modelling vs. tree-ring measurements - Comparison of growth dynamic estimates at two distinct oak forests in Croatia. South-East Eur. For. 8, 71-84. https://doi.org/10.15177/seefor.17-17

Sharpley, A.N., Daniel, T., Gibson, G., Bundy, L., Cabrera, M., Sims, T., Stevens, R., Lemunyon, J., Kleinman, P., Parry, R., 2006. Best Management Practices To Minimize Agricultural Phosphorus Impacts on Water Quality.

Sith, R., Watanabe, A., Nakamura, T., Yamamoto, T., Nadaoka, K., 2019. Assessment of water quality and evaluation of best management practices in a small agricultural watershed adjacent to Coral Reef area in Japan. Agric. Water 
Exploring the possibilities of parsimonious nitrogen modelling in different ecosystems

Manag. 213, 659-673. https://doi.org/10.1016/j.agwat.2018.11.014

Smil, V., 1999. Detonator of the population explosion. Nature 400, 415-415. https://doi.org/10.1038/22672

Smith, P., Smith, J.U., Franko, U., Kuka, K., Romanenkov, V.A., Shevtsova, L.K., Wattenbach, M., Gottschalk, P., Sirotenko, O.D., Rukhovich, D.I., Koroleva, P. V., Romanenko, I.A., Lisovoi, N. V., 2007. Changes in mineral soil organic carbon stocks in the croplands of European Russia and the Ukraine, 1990-2070; Comparison of three models and implications for climate mitigation. Reg. Environ. Chang. 7, 105-119. https://doi.org/10.1007/s10113-007-0028-2

Sougnez, N., van Wesemael, B., Vanacker, V., 2011. Low erosion rates measured for steep, sparsely vegetated catchments in southeast Spain. Catena. https://doi.org/10.1016/j.catena.2010.08.010

Spinoni, J., Vogt, J. V., Naumann, G., Barbosa, P., Dosio, A., 2018. Will drought events become more frequent and severe in Europe? Int. J. Climatol. 38, 17181736. https://doi.org/10.1002/joc.5291

Stocker, B.D., Prentice, I.C., Cornell, S.E., Davies-Barnard, T., Finzi, A.C., Franklin, O., Janssens, I., Larmola, T., Manzoni, S., Näsholm, T., Raven, J.A., Rebel, K.T., Reed, S., Vicca, S., Wiltshire, A., Zaehle, S., 2016. Terrestrial nitrogen cycling in Earth system models revisited. New Phytol. 210, 1165-1168. https://doi.org/10.1111/nph.13997

Strauch, M., Lima, J.E.F.W., Volk, M., Lorz, C., Makeschin, F., 2013. The impact of Best Management Practices on simulated streamflow and sediment load in a Central Brazilian catchment. J. Environ. Manage. 127, S24-S36. https://doi.org/10.1016/j.jenvman.2013.01.014

Suárez-Rey, E.M., Romero-Gámez, M., Giménez, C., Thompson, R.B., Gallardo, M., 2016. Use of EU-Rotate_N and CropSyst models to predict yield, growth and water and $\mathrm{N}$ dynamics of fertigated leafy vegetables in a Mediterranean climate and to determine $\mathrm{N}$ fertilizer requirements. Agric. Syst. 149, 150-164. https://doi.org/10.1016/j.agsy.2016.09.007

Swaffer, B.A., Holland, K.L., Doody, T.M., Li, C., Hutson, J., 2014. Water use strategies of two co-occurring tree species in a semi-arid karst environment. Hydrol. Process. 28, 2003-2017. https://doi.org/10.1002/hyp.9739

Tateno, R., Taniguchi, T., Zhang, J.-G., Shi, W.Y., Zhang, J.G., Du, S., Yamanaka, N., 2017. Net primary production, nitrogen cycling, biomass allocation, and 
Exploring the possibilities of parsimonious nitrogen modelling in different ecosystems

resource use efficiency along a topographical soil water and nitrogen gradient in a semi-arid forest near an arid boundary. Plant Soil 420, 209-222. https://doi.org/10.1007/s11104-017-3390-y

Taylor, J.P., Wilson, B., Mills, M.S., Burns, R.G., 2002. Comparison of microbial numbers and enzymatic activities in surface soils and subsoils using various techniques. Soil Biol. Biochem. 34, 387-401. https://doi.org/10.1016/S00380717(01)00199-7

Thornton, P.E., Law, B.E., Gholz, H.L., Clark, K.L., Falge, E., Ellsworth, D.S., Goldstein, A.H., Monson, R.K., Hollinger, D., Falk, M., Chen, J., Sparks, J.P., 2002. Modeling and measuring the effects of disturbance history and climate on carbon and water budgets in evergreen needleleaf forests. Agric. For. Meteorol. 113, 185-222. https://doi.org/10.1016/S0168-1923(02)00108-9

Tie, Q., Hu, H., Tian, F., Holbrook, N.M., 2018. Comparing different methods for determining forest evapotranspiration and its components at multiple temporal scales. Sci. Total Environ. 633, 12-29. https://doi.org/10.1016/j.scitotenv.2018.03.082

Tilman, D., Balzer, C., Hill, J., Befort, B.L., 2011. Global food demand and the sustainable intensification of agriculture. Proc. Natl. Acad. Sci. U. S. A. 108, 20260-20264. https://doi.org/10.1073/pnas.1116437108

Tilman, D., Cassman, K.G., Matson, P.A., Naylor, R., Polasky, S., 2002. Agricultural sustainability and intensive production practices. Nature 418, 671-677. https://doi.org/10.1038/nature01014

Tsakovski, S., Kudłak, B., Simeonov, V., Wolska, L., Garcia, G., Dassenakis, M., Namieśnik, J., 2009. N-way modelling of sediment monitoring data from Mar Menor lagoon, Spain. Talanta 80, 935-941. https://doi.org/10.1016/j.talanta.2009.08.015

Uhlenbrook, S., Sieber, A., 2005. On the value of experimental data to reduce the prediction uncertainty of a process-oriented catchment model. Environ. Model. Softw. 20, 19-32. https://doi.org/10.1016/j.envsoft.2003.12.006

Ullrich, A., Volk, M., 2009. Application of the Soil and Water Assessment Tool (SWAT) to predict the impact of alternative management practices on water quality and quantity. Agric. Water Manag. 96, 1207-1217. https://doi.org/10.1016/j.agwat.2009.03.010

Uscola, M., Villar-Salvador, P., Oliet, J., Warren, C.R., 2017. Root uptake of inorganic 
Exploring the possibilities of parsimonious nitrogen modelling in different ecosystems

and organic $\mathrm{N}$ chemical forms in two coexisting Mediterranean forest trees. Plant Soil 415, 387-392. https://doi.org/10.1007/s11104-017-3172-6

Van Oijen, M., Cameron, D.R., Butterbach-Bahl, K., Farahbakhshazad, N., Jansson, P.E., Kiese, R., Rahn, K.H., Werner, C., Yeluripati, J.B., 2011. A Bayesian framework for model calibration, comparison and analysis: Application to four models for the biogeochemistry of a Norway spruce forest. Agric. For. Meteorol. 151, 1609-1621. https://doi.org/10.1016/j.agrformet.2011.06.017

Van Vooren, L., Reubens, B., Broekx, S., De Frenne, P., Nelissen, V., Pardon, P., Verheyen, K., 2017. Ecosystem service delivery of agri-environment measures: A synthesis for hedgerows and grass strips on arable land. Agric. Ecosyst. Environ. 244, 32-51. https://doi.org/10.1016/j.agee.2017.04.015

Vanderwel, M.C., Coomes, D.A., Purves, D.W., 2013. Quantifying variation in forest disturbance, and its effects on aboveground biomass dynamics, across the eastern United States. Glob. Chang. Biol. 19, 1504-1517. https://doi.org/10.1111/gcb.12152

Velasco, A.M., Pérez-Ruzafa, A., Martínez-Paz, J.M., Marcos, C., 2018. Ecosystem services and main environmental risks in a coastal lagoon (Mar Menor, Murcia, SE Spain): The public perception. J. Nat. Conserv. 43, 180-189. https://doi.org/10.1016/j.jnc.2017.11.002

Velasco, J., Lloret, J., Millan, A., Marin, A., Barahona, J., Abellan, P., SanchezFernandez, D., 2006. Nutrient and particulate inputs into the Mar Menor lagoon (Se Spain) from an intensive agricultural watershed. Water. Air. Soil Pollut. 176, 37-56. https://doi.org/10.1007/s11270-006-2859-8

Verburg, P.S.J., Johnson, D.W., 2001. A spreadsheet-based biogeochemical model to simulate nutrient cycling processes in forest ecosystems. Ecol. Modell. 141, 185-200. https://doi.org/10.1016/S0304-3800(01)00273-3

Vicente, E., Vilagrosa, A., Ruiz-Yanetti, S., Manrique-Alba, À., González-Sanchís, M., Moutahir, H., Chirino, E., del Campo, A., Bellot, J., 2018. Water balance of Mediterranean Quercus ilex L. and Pinus halepensis mill. forests in semiarid climates: A review in a climate change context. Forests. https://doi.org/10.3390/f9070426

Vrugt, J.A., Gupta, H. V., Bastidas, L.A., Bouten, W., Sorooshian, S., 2003. Effective and efficient algorithm for multiobjective optimization of hydrologic models. Water Resour. Res. 39. https://doi.org/10.1029/2002WR001746 
Exploring the possibilities of parsimonious nitrogen modelling in different ecosystems

Wade, A.J., Durand, P., Beaujouan, V., Wessel, W.W., Raat, K.J., Whitehead, P.G., Butterfield, D., Rankinen, K., Lepisto, A., 2002. A nitrogen model for European catchments: INCA, new model structure and equations. Hydrol. Earth Syst. Sci. 6, 559-582. https://doi.org/10.5194/hess-6-559-2002

Wagena, M.B., Easton, Z.M., 2018. Agricultural conservation practices can help mitigate the impact of climate change. Sci. Total Environ. 635, 132-143. https://doi.org/10.1016/j.scitotenv.2018.04.110

Walker, W.E., Harremoës, P., Rotmans, J., Van der Sluijs, J.P., Van Asselt, M.B.A., Janssen, P., Krayer von Krauss, M.P., 2003. Integrated assessment. Integr. Assess. 4, 5-17. https://doi.org/1389-5176/03/0000-000\$16.00

Wang, C., Wang, S., Fu, B., Li, Z., Wu, X., Tang, Q., 2017. Precipitation gradient determines the tradeoff between soil moisture and soil organic carbon, total nitrogen, and species richness in the Loess Plateau, China. Sci. Total Environ. 575, 1538-1545. https://doi.org/10.1016/J.SCITOTENV.2016.10.047

Wang, W., Xie, Y., Bi, M., Wang, X., Lu, Y., Fan, Z., 2018. Effects of best management practices on nitrogen load reduction in tea fields with different slope gradients using the SWAT model. Appl. Geogr. 90, 200-213. https://doi.org/10.1016/j.apgeog.2017.08.020

Weil, R.R., Brady, N.C., 2017. The nature and properties of soils, 15th ed. Harlow, England : Pearson Education.

Whitehead, P.G., Sarkar, S., Jin, L., Futter, M.N., Caesar, J., Barbour, E., Butterfield, D., Sinha, R., Nicholls, R., Hutton, C., Leckie, H.D., 2015. Dynamic modeling of the Ganga river system: Impacts of future climate and socio-economic change on flows and nitrogen fluxes in India and Bangladesh. Environ. Sci. Process. Impacts 17, 1082-1097. https://doi.org/10.1039/c4em00616j

Williams, J.R., 1991. Runoff and Water Erosion, in: Modeling Plant and Soil Systems. American Society of Agronomy, Crop Science Society of America, Soil Science Society of America, Madison, WI 53711, USA, pp. 439-455. https://doi.org/10.2134/agronmonogr31.c18

Wischmeier, W.H., Smith, D.D., 1978. Predicting rainfall erosion losses - a guide to conservation planning. United States Department of Agriculture (USDA). Washington, DC, USA.

Witty, J.H., Graham, R.C., Hubbert, K.R., Doolittle, J.A., Wald, J.A., 2003. Contributions of water supply from the weathered bedrock zone to forest soil 
Exploring the possibilities of parsimonious nitrogen modelling in different ecosystems

quality. Geoderma 114, 389-400. https://doi.org/10.1016/S0016-7061(03)00051$\mathrm{X}$

Wöhling, T., Gayler, S., Priesack, E., Ingwersen, J., Wizemann, H.D., Högy, P., Cuntz, M., Attinger, S., Wulfmeyer, V., Streck, T., 2013. Multiresponse, multiobjective calibration as a diagnostic tool to compare accuracy and structural limitations of five coupled soil-plant models and CLM3.5. Water Resour. Res. 49, 82008221. https://doi.org/10.1002/2013WR014536

Woodrow, I.E., Berry, J.A., 1988. Enzymatic regulation of photosynthetic CO2 fixation in C3 Plants. Annu. Rev. Plant Physiol. Plant Mol. Biol. 39, 533-594. https://doi.org/10.1146/annurev.pp.39.060188.002533

Yang, X., Tan, L., He, R., Fu, G., Ye, J., Liu, Q., Wang, G., 2017. Stochastic sensitivity analysis of nitrogen pollution to climate change in a river basin with complex pollution sources. Environ. Sci. Pollut. Res. 24, 26545-26561. https://doi.org/10.1007/s11356-017-0257-y

Yapo, P.O., Gupta, H.V., Sorooshian, S., 1998. Multi-objective global optimization for hydrologic models. J. Hydrol. 204, 83-97. https://doi.org/10.1016/S00221694(97)00107-8

Yaseef, N.R., Yakir, D., Rotenberg, E., Schiller, G., Cohen, S., 2010. Ecohydrology of a semi-arid forest: Partitioning among water balance components and its implications for predicted precipitation changes. Ecohydrology 3, 143-154. https://doi.org/10.1002/eco.65

Zhang, C., Li, C., Chen, X., Luo, G., Li, L., Li, X., Yan, Y., Shao, H., 2013. A spatialexplicit dynamic vegetation model that couples carbon, water, and nitrogen processes for arid and semiarid ecosystems. J. Arid Land 5, 102-117. https://doi.org/10.1007/s40333-013-0146-2

Zhang, Y., Collins, A.L., Murdoch, N., Lee, D., Naden, P.S., 2014. Cross sector contributions to river pollution in England and Wales: Updating waterbody scale information to support policy delivery for the Water Framework Directive. Environ. Sci. Policy 42, 16-32. https://doi.org/10.1016/j.envsci.2014.04.010

Zhang, Yongqiang, Peña-Arancibia, J.L., McVicar, T.R., Chiew, F.H.S., Vaze, J., Liu, C., Lu, X., Zheng, H., Wang, Y., Liu, Y.Y., Miralles, D.G., Pan, M., 2016. Multidecadal trends in global terrestrial evapotranspiration and its components. Sci. Rep. 6, 1-12. https://doi.org/10.1038/srep19124 
Exploring the possibilities of parsimonious nitrogen modelling in different ecosystems

Zhang, Yongyong, Zhou, Y., Shao, Q., Liu, H., Lei, Q., Zhai, X., Wang, X., 2016. Diffuse nutrient losses and the impact factors determining their regional differences in four catchments from North to South China. J. Hydrol. 543, 577594. https://doi.org/10.1016/j.jhydrol.2016.10.031

Zhou, C.W., Yang, R., Yu, L.F., Zhang, Y., Yan, L.B., 2019. Hydrological and ecological effects of climate change in caohai watershed based on swat model. Appl. Ecol. Environ. Res. 17, 161-172. https://doi.org/10.15666/aeer/1701_161172 


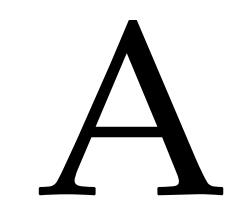

\section{Plot scale models parameters}

The parameter values obtained after the calibration process of BIOME, LEACHM and TETIS-CN are listed below. Hydrological, carbon and nitrogen parameters are compiled in Table A-1 for BIOME, Table A-2 for LEACHM and Table A-3 for TETIS. 
Exploring the possibilities of parsimonious nitrogen modelling in different ecosystems

Table A-1 I BIOME parameter values. Non-shaded parameters were fixed and not included in the calibration process.

\begin{tabular}{|c|c|c|}
\hline Parameter & Units & Value \\
\hline \multicolumn{3}{|l|}{ PLANT FUNCTIONING PARAMETERS } \\
\hline Transfer growth period as fraction of growing season & Prop. & 0.80 \\
\hline Litterfall as fraction of growing season & Prop. & 0.80 \\
\hline Base temperature & ${ }^{\circ} \mathrm{C}$ & 10 \\
\hline Min. temperature for growth displayed on current day & ${ }^{\circ} \mathrm{C}$ & 0 \\
\hline Optimal1 temperature for growth displayed on current day & ${ }^{\circ} \mathrm{C}$ & 11 \\
\hline Optimal2 temperature for growth displayed on current day & ${ }^{\circ} \mathrm{C}$ & 28 \\
\hline Max. temperature for growth displayed on current day & ${ }^{\circ} \mathrm{C}$ & 40 \\
\hline $\begin{array}{l}\text { Min. temperature for carbon assimilation displayed on } \\
\text { current day }\end{array}$ & ${ }^{\circ} \mathrm{C}$ & 0 \\
\hline $\begin{array}{l}\text { Optimal1 temperature for carbon assimilation displayed on } \\
\text { current day }\end{array}$ & ${ }^{\circ} \mathrm{C}$ & 12 \\
\hline $\begin{array}{l}\text { Optimal } 2 \text { temperature for carbon assimilation displayed on } \\
\text { current day }\end{array}$ & ${ }^{\circ} \mathrm{C}$ & 28 \\
\hline $\begin{array}{l}\text { Max. temperature for carbon assimilation displayed on } \\
\text { current day }\end{array}$ & ${ }^{\circ} \mathrm{C}$ & 40 \\
\hline Annual leaf and fine root turnover fraction & $\mathrm{yr}^{-1}$ & 0.20 \\
\hline Annual live wood turnover fraction & $\mathrm{yr}^{-1}$ & 0.30 \\
\hline Annual whole-plant mortality fraction & $\mathrm{yr}^{-1}$ & 0.02 \\
\hline Annual fire mortality fraction & $\mathrm{yr}^{-1}$ & 0 \\
\hline C:N of leaves & $\mathrm{kgC} \mathrm{kgN}^{-1}$ & 37.50 \\
\hline C:N of leaf litter, after retranslocation & $\mathrm{kgC} \mathrm{kgN}^{-1}$ & 46.50 \\
\hline $\mathrm{C}: \mathrm{N}$ of fine roots & $\mathrm{kgC} \mathrm{kgN-1}^{-1}$ & 43 \\
\hline $\mathrm{C}: \mathrm{N}$ of fruit & $\mathrm{kgC} \mathrm{kgN-1}^{-1}$ & 47 \\
\hline $\mathrm{C}: \mathrm{N}$ of soft stem & $\mathrm{kgC} \mathrm{kgN}^{-1}$ & 0.00 \\
\hline C:N of live wood & $\mathrm{kgC} \mathrm{kgN}^{-1}$ & 73.50 \\
\hline C:N of dead wood & $\mathrm{kgC} \mathrm{kgN}^{-1}$ & 651 \\
\hline Leaf litter labile proportion & {$[-]$} & 0.20 \\
\hline Leaf litter cellulose proportion & {$[-]$} & 0.56 \\
\hline Fine root labile proportion & {$[-]$} & 0.34 \\
\hline Fine root cellulose proportion & {$[-]$} & 0.44 \\
\hline Fruit litter labile proportion & {$[-]$} & 0.30 \\
\hline Fruit litter cellulose proportion & {$[-]$} & 0.29 \\
\hline Soft stem litter labile proportion & {$[-]$} & 0.00 \\
\hline Soft stem litter cellulose proportion & {$[-]$} & 0.00 \\
\hline
\end{tabular}


Exploring the possibilities of parsimonious nitrogen modelling in different ecosystems

Dead wood cellulose proportion

$[-]$

0.75

Canopy water interception coefficient

$\mathrm{LAI}^{-1} \mathrm{~d}^{-1}$

0.25

Canopy light extinction coefficient

$[-]$

0.36

Potential radiation use efficiency

$\mathrm{g} \mathrm{MJ}^{-1} \quad 2$

Radiation parameter1 (Jiang et al.2015)

$[-]$

0.78

Radiation parameter2 (Jiang et al.2015)

$[-]$

13.60

All-sided to projected leaf area ratio

Ratio of shaded SLA:sunlit SLA

Fraction of leaf $\mathbf{N}$ in Rubisco

[-] $\quad 1.1 \mathrm{e}-2$

Fraction of leaf $\mathrm{N}$ in PEP Carboxylase

$[-]$

$1 \mathrm{e}-4$

Max. stomatal conductance (projected area basis)

$\mathrm{m} \mathrm{s}^{-1} \quad 9 \mathrm{e}-03$

Cuticular conductance (projected area basis)

$\mathrm{m} \mathrm{s}^{-1} \quad 7 \mathrm{e}-04$

Boundary layer conductance (projected area basis)

$\mathrm{m} \mathrm{s}^{-1} \quad$ 5e-4

Relative SWC (prop. to FC) to calc. soil moisture limit 1

Prop.

0.35

Relative SWC (prop. to SAT) to calc. soil moisture limit 2

Prop.

0.68

Relative PSI (prop. to FC) to calc. soil moisture limit 1

Prop. $\quad-9999$

Relative PSI (prop. to SAT) to calc. soil moisture limit 2

Prop.

$-9999$

Vapour pressure deficit: start of conductance reduction

$\mathrm{Pa} \quad 100$

Vapour pressure deficit: complete conductance reduction

$\mathrm{Pa}$

800.78

Maximum height of plant

$\mathrm{m}$

8.50

Stem weight at which maximum height attended

Maximum depth of rooting zone

$\mathrm{kgC} \mathrm{m} \mathrm{m}^{-2}$

$\mathrm{m}$

[-]

$\mathrm{kgC} \mathrm{m}^{-2}$

Prop.

Prop.

$\mathrm{kgC} \mathrm{kgN}^{-1} \mathrm{~d}^{-1} \quad 8.8 \mathrm{e}-2$

Maintenance respiration in $\mathrm{kgC/day}$ per $\mathrm{kg}$ of tissue $\mathrm{N}$

Theoretical maximum prop. of non-structural and structural carbohydrates

Prop. of non-structural carbohydrates available for maintenance respiration

Symbiotic + asymbiotic fixation of $\mathrm{N}$

$\mathrm{kgN} \mathrm{m}^{-2} \mathrm{yr}^{-1} \quad 5 \mathrm{e}-4$

Max. senescence mortality coefficient of aboveground plant material

Prop.

0.03

Max. senescence mortality coefficient of belowground plant material

Prop.

0.03 
Exploring the possibilities of parsimonious nitrogen modelling in different ecosystems

Max. senescence mortality coefficient of non-structured plant material

Prop. $\quad 0$

Effect of extreme high temperature on senescence mortality

Prop. 2

Lower limit extreme high temperature effect on senescence mortality

${ }^{\circ} \mathrm{C} \quad 45$

Upper limit extreme high temperature effect on senescence mortality

Maximal lifetime of plant tissue

$\begin{array}{lr}{ }^{\circ} \mathrm{C} & 50 \\ { }^{\circ} \mathrm{C} & -9999\end{array}$

Turnover rate of wilted standing biomass to litter

Prop.

0.01

Turnover rate of non-woody cut-down biomass to litter

Prop.

0.05

Turnover rate of woody cut-down biomass to litter

Prop.

0.01

Drought tolerance parameter (critical value of DSWS)

Prop.

90

Denitrification rate per $\mathrm{g}$ of $\mathrm{CO}_{2}$ respiration of $\mathrm{SOM}$

Prop.

0.08

Nitrification coefficient 1

Prop.

0.30

Nitrification coefficient 2

Prop.

0.10

Coefficient of $\mathrm{N}_{2} \mathrm{O}$ emission of nitrification

Prop.

0.02

Proportion of $\mathrm{NH}_{4}$ flux of $\mathrm{N}$-deposition

Prop.

0.80

$\mathrm{NH}_{4}$ mobile proportion

Prop. $\quad 0.90$

$\mathrm{NO}_{3}$ mobile proportion

e-folding depth of decomposition rate's depth scalar

Prop.

$\mathrm{m}$

Fraction of dissolved part of SOIL1 organic matter

Prop. $\quad 1 \mathrm{e}-3$

Fraction of dissolved part of SOIL2 organic matter

Prop. $\quad 1 e-3$

Fraction of dissolved part of SOIL3 organic matter

Prop. $\quad 1 e-3$

Fraction of dissolved part of SOIL4 organic matter

Prop. $\quad 1 \mathrm{e}-3$

Ratio of bare soil evaporation and pot. evaporation

\section{RATE SCALARS}

Resp. fractions for fluxes between compartments (11s1)

Resp. fractions for fluxes between compartments (12s2)

Resp. fractions for fluxes between compartments (14s3)

Resp. fractions for fluxes between compartments (s1s2)

Resp. fractions for fluxes between compartments (s2s3)

Resp. fractions for fluxes between compartments (s3s4)

Rate constant scalar of labile litter pool

Rate constant scalar of cellulose litter pool

Rate constant scalar of lignin litter pool

Rate constant scalar of fast microbial recycling pool

[-] 0.07

Rate constant scalar of medium microbial recycling pool

Rate constant scalar of slow microbial recycling pool

$[-] \quad 1.4 \mathrm{e}-3$


Exploring the possibilities of parsimonious nitrogen modelling in different ecosystems

Rate constant scalar of recalcitrant SOM (humus) pool

[-] $\quad 1 \mathrm{e}-4$

Rate constant scalar of physical fragmentation of coarse

woody debris

$[-] \quad 1 e-3$

GROWING SEASON PARAMETERS

Critical amount of snow limiting photosynthesis

Limit1 (under:full constrained) of HEATSUM index

$\mathrm{kg} \mathrm{m}^{-2} \quad 5$

Limit2 (above:unconstrained) of HEATSUM index

${ }^{\circ} \mathrm{C}$

20

Limit1 (under:full constrained) of TMIN index

${ }^{\circ} \mathrm{C} \quad 60$

Limit2 (above:unconstrained) of TMIN index

${ }^{\circ} \mathrm{C} \quad 0$

Limit1 (above:full constrained) of VPD index

${ }^{\circ} \mathrm{C}$

5

Limit2 (under:unconstrained) of VPD index

Limit1 (under:full constrained) of DAYLENGTH index

$\mathrm{Pa}$

4000

Limit2 (above:unconstrained) of DAYLENGTH index

$\mathrm{Pa} \quad 1000$

Moving average (to avoid the effects of extreme events)

$\mathrm{S}$

0

$\mathrm{S}$

0

GSI limit1 (greater that limit $->$ start of vegper)

day

10

GSI limit2 (less that limit $\rightarrow$ end of vegper)

[-]

CH4 PARAMETERS

Param1 for $\mathrm{CH} 4$ calculations (empirical function of BD)

$[-]$

0.01

[- $\quad 212.50$

Param2 for $\mathrm{CH} 4$ calculations (empirical function of BD)

$[-] \quad 1.81$

Param1 for $\mathrm{CH} 4$ calculations (empirical function of VWC)

[-] $\quad-1.35$

Param2 for $\mathrm{CH} 4$ calculations (empirical function of VWC)

[-] $\quad 0.20$

Param3 for $\mathrm{CH} 4$ calculations (empirical function of VWC)

[-] $\quad 1.78$

Param4 for $\mathrm{CH} 4$ calculations (empirical function of VWC)

$[-]$

6.79

Param1 for $\mathrm{CH} 4$ calculations (empirical function of Tsoil)

$[-$

0.01

PHENOLOGICAL PARAMETERS

Length of phenophase (growing degree days). Phase 1

Length of phenophase (growing degree days). Phase 2

Length of phenophase (growing degree days). Phase 3

Length of phenophase (growing degree days). Phase 4

Length of phenophase (growing degree days). Phase 5

Length of phenophase (growing degree days). Phase 6

Length of phenophase (growing degree days). Phase 7

Leaf allocation. Phase 1 to phase 7

Fine root allocation. Phase 1 to phase 7

$\begin{array}{ll}{ }^{\circ} \mathrm{C} & 500 \\ { }^{\circ} \mathrm{C} & 200 \\ { }^{\circ} \mathrm{C} & 500 \\ { }^{\circ} \mathrm{C} & 200 \\ { }^{\circ} \mathrm{C} & 400 \\ { }^{\circ} \mathrm{C} & 200 \\ { }^{\circ} \mathrm{C} & 100\end{array}$

Fruit allocation. Phase 1 to phase 7

Ratio

0.40

Soft stem allocation. Phase 1 to phase 7

Ratio

0.20

Ratio

0.20

Live woody stem allocation. Phase 1 to phase 7

Ratio

0.00

Ratio

0.1 
Exploring the possibilities of parsimonious nitrogen modelling in different ecosystems

Dead woody stem allocation. Phase 1 to phase 7

Ratio $\quad 0.00$

Live coarse root allocation. Phase 1 to phase 7

Ratio $\quad 0.10$

Dead coarse root allocation. Phase 1 to phase 7

Ratio $\quad 0.00$

Canopy average specific leaf area. Phase 1 to phase 7 $\mathrm{m}^{2} \mathrm{kgC}^{-1} \quad 9.81$

Current growth proportion. Phase 1 to phase 7

Prop.

0.5 
Exploring the possibilities of parsimonious nitrogen modelling in different ecosystems

Table A-2 I LEACHM parameter values. Non-shaded parameters were fixed and not included in the calibration process.

\begin{tabular}{|c|c|c|}
\hline Parameter & Units & Value \\
\hline \multicolumn{3}{|c|}{ HYDROLOGICAL PARAMETERS } \\
\hline Largest time interval within a day & day & 0.05 \\
\hline Profile depth & $\mathrm{mm}$ & 1100 \\
\hline Segment thickness & $\mathrm{mm}$ & 50 \\
\hline Depth to water table & $\mathrm{m}$ & 47.92 \\
\hline Clay & $\%$ & 23.0 \\
\hline Silt & $\%$ & 33.1 \\
\hline Organic carbon & $\%$ & 12.0 \\
\hline Pan factor & {$[-]$} & 0.278 \\
\hline Vegetation cover factor & {$[-]$} & 0.416 \\
\hline Roots percentage in layer 1 & {$[-]$} & 0.008 \\
\hline Roots percentage in layer 2 & {$[-]$} & 0.190 \\
\hline Roots percentage in layer 3 & {$[-]$} & 0.235 \\
\hline Roots percentage in layer 4 & {$[-]$} & 0.199 \\
\hline Roots percentage in layer 5 & {$[-]$} & 0.180 \\
\hline Roots percentage in layer 6 & {$[-]$} & 0.146 \\
\hline Roots percentage in layer 7 & {$[-]$} & 0.008 \\
\hline Clay particle density & $\mathrm{kg} \mathrm{dm}{ }^{-3}$ & 2.65 \\
\hline Sand and silt particle density & $\mathrm{kg} \mathrm{dm}^{-3}$ & 2.65 \\
\hline Organic matter particle density & $\mathrm{kg} \mathrm{dm} \mathrm{m}^{-3}$ & 1.10 \\
\hline Bulk density & $\mathrm{kg} \mathrm{dm}^{-3}$ & 1.46 \\
\hline a coefficient Campbell's equation (layers 1-2) & $\mathrm{kPa}$ & -1.687 \\
\hline b coefficient Campbell's equation (layers 1-2) & {$[-]$} & 2.153 \\
\hline Saturated hydraulic conductivity (layers 1-2) & $\mathrm{mm} \mathrm{d}^{-1}$ & 83.50 \\
\hline a coefficient Campbell's equation (layers 3-4) & $\mathrm{kPa}$ & -2.398 \\
\hline b coefficient Campbell's equation (layers 3-4) & {$[-]$} & 4.024 \\
\hline Saturated hydraulic conductivity (layers $3-4$ ) & $\mathrm{mm} \mathrm{d}^{-1}$ & 30.82 \\
\hline a coefficient Campbell's equation (layers 5-6) & $\mathrm{kPa}$ & -2.951 \\
\hline b coefficient Campbell's equation (layers 5-6) & {$[-]$} & 5.760 \\
\hline Saturated hydraulic conductivity (layers 5-6) & $\mathrm{mm} \mathrm{d}^{-1}$ & 74.57 \\
\hline a coefficient Campbell's equation (layers 6-22) & $\mathrm{kPa}$ & -3.777 \\
\hline b coefficient Campbell's equation (layers 6-22) & {$[-]$} & 13.920 \\
\hline Saturated hydraulic conductivity (layers 6-22) & $\mathrm{mm} \mathrm{d}^{-1}$ & 39.223 \\
\hline Dispersivity & $\mathrm{mm}$ & 100 \\
\hline Curve number & {$[-]$} & 55 \\
\hline Slope & $\%$ & 31 \\
\hline Wilting point & $\mathrm{kPa}$ & -1500 \\
\hline
\end{tabular}


Exploring the possibilities of parsimonious nitrogen modelling in different ecosystems

Minimum root water potential $\mathrm{kPa} \quad-3000$

Maximum ratio of actual to potential transpiration

[-] $\quad 0.6$

Root resistance

CARBON AND NITROGEN PARAMETERS

\begin{tabular}{lcc}
\hline Mineral nitrogen fixed & $\mathrm{kgN} \mathrm{ha}^{-1} \mathrm{yr}^{-1}$ & 0 \\
Plant death constant & $\mathrm{gC} \mathrm{m}^{-2} \mathrm{~d}^{-1}$ & 0.31 \\
Plant residue input C/N ratio & {$[-]$} & 21.60 \\
Biomass and humus C/N ratio & {$[-]$} & 14 \\
Synthesis efficiency factor & {$[-]$} & 0.20 \\
Humification factor & {$[-]$} & 0.55 \\
Residue mineralization rate (layers 1-3) & $\mathrm{day}^{-1}$ & $1.39 \mathrm{e}-3$ \\
Humus mineralization rate (layers 1-3) & $\mathrm{day}^{-1}$ & $4.52 \mathrm{e}-6$ \\
Manure mineralization rate (layers 1-3) & $\mathrm{day}^{-1}$ & 0.00 \\
NH4 ${ }^{+}$distribution coefficient & $\mathrm{dm}^{3} \mathrm{~kg}^{-1}$ & 6.85 \\
Molecular diffusion coefficient & $\mathrm{mm}^{2} \mathrm{day}^{-1}$ & 120 \\
Volatilization rate & $\mathrm{day}^{-1}$ & 0.24 \\
Nitrification rate (layers 1-3) & $\mathrm{day}^{-1}$ & $7.14 \mathrm{e}-2$ \\
Denitrification rate (layers 1-3) & $\mathrm{day}^{-1}$ & 0.57 \\
Plant nitrogen potential uptake & $\mathrm{kgN} \mathrm{ha}^{-1} \mathrm{yr}^{-1}$ & 61.84 \\
Base temperature & ${ }^{\circ} \mathrm{C}$ & 20 \\
Q10 & {$[-]$} & 2.22 \\
High end of optimum water content range & {$[-]$} & 0.08 \\
Lower end of optimum water content & $\mathrm{kPa}^{-1}$ & -162.23 \\
Minimum matric potential for transformation & $\mathrm{kPa}^{-1}$ & -1000 \\
Relative transformation rate at saturation & $\mathrm{day}^{-1}$ & 0.6 \\
Urea hydrolysis & $\mathrm{day}^{-1}$ & 0.00 \\
Denitrification half-saturation constant & $\mathrm{mg} \mathrm{l}^{-1}$ & 10 \\
Limiting NO & {$[-]$} & 7.40 \\
\hline & & \\
\hline
\end{tabular}


Exploring the possibilities of parsimonious nitrogen modelling in different ecosystems

Table A-3 I TETIS-CN parameter values. Non-shaded parameters were fixed and not included in the calibration process.

\begin{tabular}{lcc}
\hline \multicolumn{1}{c}{ Parameter } & Units & Value \\
\hline Soil depth & $\mathrm{m}$ & \\
Evaporation depth & $\mathrm{m}$ & 0.296 \\
Puddle storage & $\mathrm{mm}$ & 0.138 \\
Wilting point soil moisture & $\mathrm{cm} \mathrm{cm}^{-1}$ & 0.074 \\
Optimal point soil moisture & $\mathrm{cm} \mathrm{cm}^{-1}$ & 0.037 \\
Field capacity soil moisture of the layer 1 & $\mathrm{cm} \mathrm{cm}^{-1}$ & 0.232 \\
Field capacity soil moisture of the layer 2 & $\mathrm{cm} \mathrm{cm}^{-1}$ & 0.210 \\
Infiltration exponent of the first layer & {$[-]$} & 1.618 \\
Infiltration exponent of the second layer & {$[-]$} & 0.360 \\
Correction factor for ET 0 & {$[-]$} & 0.701 \\
Vegetation cover factor & {$[-]$} & 0.419 \\
Maximum leaf water storage & $\mathrm{mm}^{2}$ & 2.528 \\
LAI 0 & $\mathrm{~m}^{2} \mathrm{~m} \mathrm{~m}^{-2}$ & 2.701 \\
Soil moisture deficit nonlinearity parameter & {$[-]$} & 3.237 \\
Roots percentage in the first layer & {$[-]$} & 0.334 \\
Fixed roots percentage in the second layer & {$[-]$} & 0.241 \\
Soil moisture threshold & $\mathrm{cm} \mathrm{cm}^{-1}$ & 0.155 \\
Surface infiltration capacity & $\mathrm{mm} \mathrm{d}^{-1}$ & infinite \\
Residence time in the surface storage & days & 1 \\
Percolation capacity to groundwater storage & $\mathrm{mm} \mathrm{d}^{-1}$ & infinite \\
Residence time in gravitational storage & days & infinite \\
\hline
\end{tabular}

CARBON AND NITROGEN PARAMETERS

\begin{tabular}{lcc}
\hline Plant death constant & $\mathrm{gC} \mathrm{m}^{-2} \mathrm{~d}^{-1}$ & 0.72 \\
Plant residue input C/N ratio & {$[-]$} & 28.94 \\
Humus C/N ratio & {$[-]$} & 20 \\
Biomass C/N ratio & {$[-]$} & 8 \\
Respiration rate & {$[-]$} & 0.6 \\
Humification factor & {$[-]$} & 0.25 \\
Litter decomposition rate & $\mathrm{m}^{3} \mathrm{~d}^{-1} \mathrm{gC}^{-1}$ & $8.00 \mathrm{e}-6$ \\
Humus decomposition rate & $\mathrm{m}^{3} \mathrm{~d}^{-1} \mathrm{gC}^{-1}$ & $3.55 \mathrm{e}-7$ \\
Microbial biomass death rate & $\mathrm{day}^{-1}$ & $2.64 \mathrm{e}-3$ \\
$\mathbf{N H}_{4}+$ distribution coefficient & $\mathrm{dm}^{3} \mathrm{~kg}^{-1}$ & 8.89 \\
Volatilization rate & $\mathrm{day}^{-1}$ & $1.29 \mathrm{e}-2$ \\
Nitrification rate & $\mathrm{m}^{3} \mathrm{~d}^{-1} \mathrm{gC}^{-1}$ & $2.78 \mathrm{e}-2$ \\
Denitrification rate & $\mathrm{day}^{-1}$ & $3.84 \mathrm{e}-2$ \\
Plant nitrogen potential uptake & $\mathrm{kgN} \mathrm{ha}^{-1} \mathrm{yr}^{-1}$ & 118.82
\end{tabular}


Exploring the possibilities of parsimonious nitrogen modelling in different ecosystems

Diffusion coefficient

$\mathrm{m} \mathrm{d}^{-1}$

0.33

Soil moisture threshold for soil water content correction function

$\mathrm{cm} \mathrm{cm}^{-1} \quad 0.19$

Maximum temperature difference

${ }^{\circ} \mathrm{C}$

1.16

Optimum temperature

${ }^{\circ} \mathrm{C} \quad 30$

Minimum temperature

${ }^{\circ} \mathrm{C}$

$-5$ 


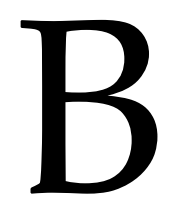

\section{TETIS-N model parameters}

The parameter values obtained after the calibration process of TETIS-N are listed below. The hydrological correction factors are listed in Table B-1, the three correction factors of the sediment sub-model are listed in Table B-2, the nitrogen parameters are listed in Table B-3, Table B-4 and Table B-5 and the crop growth sub-model parameters are listed in Table B-6. 
Exploring the possibilities of parsimonious nitrogen modelling in different ecosystems Table B-1 I TETIS-N hydrological correction factors. Non-shaded parameters were fixed and not included in the calibration process.

\begin{tabular}{lcc}
\hline \multicolumn{1}{c}{ Parameter correction factor } & Units & Value \\
\hline Maximum static storage & {$[-]$} & 1 \\
Evapotranspiration & {$[-]$} & 1.2 \\
Infiltration capacity & {$[-]$} & 0.123 \\
Hillslope surface velocity & {$[-]$} & 1 \\
Percolation capacity & {$[-]$} & 1 \\
Interflow hydraulic conductivity & {$[-]$} & 300 \\
Deep percolation & {$[-]$} & infinity \\
Base flow hydraulic conductivity & {$[-]$} & 0 \\
Flow velocity & {$[-]$} & 1 \\
\hline
\end{tabular}

Table B-2 I TETIS-N sedimentological correction factors. Non-shaded parameters were fixed and not included in the calibration process.

\begin{tabular}{lcc}
\hline \multicolumn{1}{c}{ Parameter correction factor } & Units & Value \\
\hline Hillslope transport capacity & {$[-]$} & 0.097 \\
Gully transport capacity & {$[-]$} & 1 \\
Channel transport capacity & {$[-]$} & 1 \\
\hline
\end{tabular}

Table B-3 I TETIS-N in-stream nitrogen parameters. Non-shaded parameters were fixed and not included in the calibration process.

\begin{tabular}{lccc}
\hline & Parameter & Units & Value \\
\hline Nitrification rate & day $^{-1}$ & 0 \\
Denitrification rate & day $^{-1}$ & 0 \\
\hline
\end{tabular}

Table B-4 I TETIS-N NH $4^{+}$distribution coefficient and temperature-related parameters. Nonshaded parameters were fixed and not included in the calibration process.

\begin{tabular}{lcc}
\hline \multicolumn{1}{c}{ Parameter } & Units & Value \\
\hline Correction factor of the $\mathrm{NH}_{4}{ }^{+}$distribution coefficient & {$[-]$} & 0.6 \\
Maximum temperature difference & ${ }^{\circ} \mathrm{C}$ & 10 \\
Temperature correction constant & {$[-]$} & 1.047 \\
Optimum temperature & ${ }^{\circ} \mathrm{C}$ & 20 \\
\hline
\end{tabular}


Table B-5 I TETIS-N land use specific nitrogen parameters. Non-shaded parameters were fixed and not included in the calibration process.

\begin{tabular}{|c|c|c|c|c|c|c|c|c|}
\hline & \multicolumn{8}{|c|}{ Parameter } \\
\hline & $\begin{array}{c}\text { Minera- } \\
\text { lization } \\
\text { rate }\end{array}$ & $\begin{array}{c}\text { Immobi- } \\
\text { lization } \\
\text { rate }\end{array}$ & $\begin{array}{c}\text { Volatili- } \\
\text { zation } \\
\text { rate }\end{array}$ & $\begin{array}{l}\text { Nitrifica- } \\
\text { tion rate }\end{array}$ & $\begin{array}{c}\text { Denitri- } \\
\text { fication } \\
\text { rate }\end{array}$ & $\begin{array}{c}\text { Diffu- } \\
\text { sion } \\
\text { coeff. }\end{array}$ & $\begin{array}{c}\text { Potential } \\
\text { uptake }\end{array}$ & $\begin{array}{c}\text { Nitrogen } \\
\text { pref. }\end{array}$ \\
\hline Land use $\backslash$ Units & day $^{-1}$ & day $^{-1}$ & day $^{-1}$ & day $^{-1}$ & day $^{-1}$ & $m$ day $^{-1}$ & $\begin{array}{c}\mathrm{kgN} \mathrm{ha}^{-1} \\
\text { year }^{-1}\end{array}$ & {$[-]$} \\
\hline Continuous urban fabric & 0 & 0 & 0 & 0 & 0 & 0 & 0 & 0 \\
\hline Discontinuous urban fabric & 0.00008 & 0.02 & 0 & 0.05 & 0.001 & 0.1 & 7 & 0.5 \\
\hline Mineral extraction sites & 0.00003 & 0.02 & 0 & 0.1 & 0.001 & 0.1 & 3 & 0.5 \\
\hline Dump sites & 0.000028 & 0.02 & 0 & 0.1 & 0.001 & 0.1 & 2.5 & 0.5 \\
\hline Construction sites & 0.00008 & 0.02 & 0 & 0.1 & 0.001 & 0.1 & 10 & 0.5 \\
\hline Sport and leisure facilities & 0.0001 & 0.02 & 0 & 0.5 & 0.001 & 0.1 & 225 & 0.5 \\
\hline Non-irrigated arable land & 0.0001 & 0.02 & 0 & 0.5 & 0.001 & 0.2 & 75 & 1 \\
\hline Permanently irrigated arable land & 0.0001 & 0.02 & 0 & 0.8 & 0.001 & 0.2 & 460 & 1 \\
\hline Fruit trees and berry plantations & 0.0001 & 0.02 & 0 & 0.6 & 0.001 & 0.1 & 250 & 1 \\
\hline Complex cultivation patterns & 0.0001 & 0.02 & 0 & 0.3 & 0.001 & 0.1 & 40 & 1 \\
\hline Principally agricultural land & 0.0001 & 0.02 & 0 & 0.5 & 0.001 & 0.2 & 33 & 1 \\
\hline Coniferous forest & 0.000082 & 0.01 & 0 & 0.25 & 0.001 & 0.2 & 47 & 0.5 \\
\hline Sclerophylous vegetation & 0.000081 & 0.02 & 0 & 0.05 & 0.001 & 0.1 & 19 & 0.5 \\
\hline Transitional woodland & 0.000082 & 0.02 & 0 & 0.05 & 0.001 & 0.1 & 24 & 0.5 \\
\hline Beaches, dunes and sand plains & 0 & 0 & 0 & 0 & 0 & 0 & 0 & 0 \\
\hline Sparsely vegetated areas & 0.00007 & 0.02 & 0 & 0.05 & 0.001 & 0.15 & 8 & 0.5 \\
\hline Salt marshes & 0.000028 & 0.02 & 0 & 0.05 & 0.001 & 0.1 & 10 & 0.5 \\
\hline
\end{tabular}


Exploring the possibilities of parsimonious nitrogen modelling in different ecosystems

Table B-6 I TETIS-N crop growth sub-model parameters. Non-shaded parameters were fixed and not included in the calibration process.

\begin{tabular}{lccccccccccc}
\hline & $\begin{array}{c}\text { Plant } \\
\text { date }\end{array}$ & $\begin{array}{c}\text { Harvest } \\
\text { date }\end{array}$ & $\begin{array}{c}\text { Initial dry } \\
\text { matter }\end{array}$ & $\begin{array}{c}\text { Final dry } \\
\text { matter }\end{array}$ & $\begin{array}{c}\text { Initial crop } \\
\text { cover factor }\end{array}$ & $\begin{array}{c}\text { Final crop } \\
\text { cover factor }\end{array}$ & $\begin{array}{c}\text { Base } \\
\text { temperature }\end{array}$ & $\begin{array}{c}\text { A crop } \\
\text { coeff. }\end{array}$ & $\begin{array}{c}\text { B crop } \\
\text { coeff. }\end{array}$ & $\begin{array}{c}\text { Nitrogen } \\
\text { pref. }\end{array}$ \\
\cline { 2 - 11 } Crop & {$[-]$} & {$[-]$} & $\begin{array}{c}\mathrm{Mg} \mathrm{ha}^{-1} \\
\text { year-1 }^{-1}\end{array}$ & $\begin{array}{c}\mathrm{Mg} \mathrm{ha}^{-1} \\
\text { year }^{-1}\end{array}$ & {$[-]$} & {$[-]$} & ${ }^{\circ} \mathrm{C}$ & & {$[-]$} & {$[-]$} & {$[-]$} \\
\hline Broccoli & Jan 1 & Apr 30 & 0.02 & 8.68 & 0.02 & 0.95 & 1 & 2.40 & 0.6 & 1 \\
Melon & Jun 1 & Aug 31 & 0.008 & 1.03 & 0.05 & 0.90 & 7 & 2.48 & 5 & 1 \\
Lettuce & Oct 1 & Dec 31 & 0.02 & 3.28 & 0.05 & 0.90 & 7 & 2.60 & 1.1 & 1 \\
\hline
\end{tabular}




\section{Scientific publications}

The results of this thesis have been published in relevant international journals in the field of hydrology, ecology and agronomy, as well as in national and international conferences. Additionally, two papers not directly related to this thesis have also been published in relevant national and international journals in the field of hydrology and engineering.

\section{Journal contributions}

Puertes, C., Bautista, I., Lidón, A., Francés, F., 2020. Best management practices scenario analysis to reduce agricultural nitrogen loads and sediment yield to the semiarid Mar Menor coastal lagoon (Spain). (Under review in Agricultural Systems).

Puertes, C., González-Sanchis, M., Lidón, A., Bautista, I., del Campo, A.D., Lull, C., Francés, F., 2020. Improving the modelling and understanding of carbonnitrogen-water interactions in a semiarid Mediterranean oak forest. (Under review in Ecological Modelling).

Echeverría, C., Ruiz-Pérez, G., Puertes, C., Samaniego, L., Barrett, B., Francés, F., 2019. Assessment of remotely sensed near-surface soil moisture for distributed eco-hydrological model implementation. Water (Switzerland), 11, 2613. https://doi.org/10.3390/w11122613

Puertes, C., Lidón, A., Echeverría, C., Bautista, I., González-Sanchis, M., del Campo, A.D., Francés, F., 2019. Explaining the hydrological behaviour of facultative phreatophytes using a multi-variable and multi-objective modelling approach. Journal of Hydrology, 575, 395-407. https://doi.org/10.1016/j.hydrol.2019.05.041

Puertes, C., Francés, F., 2016. La riada de Valencia de 1957: reconstrucción hidrológica y sedimentológica y análisis comparativo con la situación actual. Ingeniería del Agua, 20(3), 59-77. 
Exploring the possibilities of parsimonious nitrogen modelling in different ecosystems

\section{Conference contributions}

Pool, S., Francés, F., García-Prats, A., Puertes, C., Pulido-Velázquez, M., SanchisIbor, C., Schirmer, M., Yang, H., Jiménez-Martínez, J. Modelling the effect of irrigation modernization on groundwater recharge. 17th Swiss Geoscience Meeting, Fribourg, 22-23 November 2019. Abstracts in web.

Echeverría, C., Puertes, C., Ruiz-Pérez, G., Barrett, B., Francés, F. Evaluación de la robustez de la implementación de un modelo hidrológico mediante la calibración con humedad del suelo superficial obtenida por teledetección. VI Jornadas de Ingeniería del Agua, 23-24 octubre 2019, Toledo.

Pool, S., Francés, F., García-Prats, A., Puertes, C., Pulido-Velázquez, M., SanchisIbor, C., Schirmer, M., Yang, H., Jiménez-Martínez, J. Modelling the spatiotemporal effects of a gradual irrigation modernization on groundwater recharge. Chapman conference, Valencia, 21-24 October 2019. Abstracts in web.

Puertes, C., Lidón, A., Echeverría, C., Bautista, I., González-Sanchis, M., del Campo, A.D., Francés, F. Proper modelling of the hydrological behaviour of facultative phreatophytes at plot scale using additional in-situ transpiration measurements. European Geosciences Union General Assembly, Vienna, 7-12 April 2018. Ed. Geophysical Research Abstracts in web, 21, 12963, ISSN: 10297006.

Francés, F., Ruiz-Pérez, G., Echeverría, G., Puertes, C. Exploiting all the available sensorized information of hydro-environmental state variables for the implementation of a mathematical model. HydroSenSoft, International Symposium and Exhivition on Hydro-Environment Sensors and Software, Madrid, 26 February - 1 March 2019.

Puertes, C., Lidón, A., Bautista, I., Francés, F. Análisis de actuaciones en la zona agrícola sur del Mar Menor sobre aportaciones de nitrógeno a la laguna. VII Jornadas del Grupo de Fertilización de la SECH, Valencia, 23-24 enero 2019.

Puertes, C., Bautista, I., Lidón, A., Francés, F. Evaluation of the measures to reduce sediments and nitrogen inputs to the Mar Menor coastal lagoon (Spain). 
Exploring the possibilities of parsimonious nitrogen modelling in different ecosystems

European Geosciences Union General Assembly, Vienna, 8-13 April 2018. Ed. Geophysical Research Abstracts in web, 20, 9038, ISSN: 1029-7006.

Romero, C., Puertes, C., Quintanilla, I., Francés, F. Analysis of the impact of urban impervious cover in a small basin: comparison between high and low spatial resolution in the water cycle using the TETIS model. European Geosciences Union General Assembly, Vienna, 8-13 April 2018. Ed. Geophysical Research Abstracts in web, 20, 6817, ISSN: 1029-7006.

Escamilla, V., Puertes, C., Francés, F. Capacidades del modelo hidrológico TETIS versión 9. V Jornadas de Ingeniería del Agua, 25-26 octubre 2017, A Coruña, Actas en web, 79-80, J. Puertas, J. Anta y M. Bermúdez. ISBN: 978-84-9749-6704.

Puertes, C., Bautista, I., Lidón, A., Francés, F. Análisis de actuaciones en las cuencas del sur del Mar Menor con el objetivo de reducir el aporte de sedimentos y compuestos nitrogenados a la laguna. V Jornadas de Ingeniería del Agua, 25-26 octubre 2017, A Coruña, Actas en web, 320-321, J. Puertas, J. Anta y M. Bermúdez. ISBN: 978-84-9749-670-4.

Puertes, C., González-Sanchis, M., Lidón, A., Bautista, I., Lull, C., del Campo, A.D., Francés, F. Carbon-nitrogen-water interactions: is model parsimony fruitful? European Geosciences Union General Assembly, Vienna, 23-28 April 2017. Ed. Geophysical Research Abstracts in web, 19, 13372, ISSN: 1029-7006.

Puertes, C., Francés, F. How important are sediments in the flood peaks generated by a Mediterranean catchment? European Geosciences Union General Assembly, Vienna, 17-22 April 2016. Ed. Geophysical Research Abstracts in web, 18, 12320, ISSN: 1029-7006.

Puertes, C., Francés, F. La riada de Valencia de 1957: reconstrucción hidrológica y sedimentológica y análisis comparativo con la situación actual. IV Jornadas de Ingeniería del Agua, 21-22 octubre 2015, Córdoba, Actas en usb, 1247-1256, M.F. Moreno Pérez y J. Roldán Cañas (eds.). ISBN: 978-84-608-3043-6. 
